XLVIII 2020/1
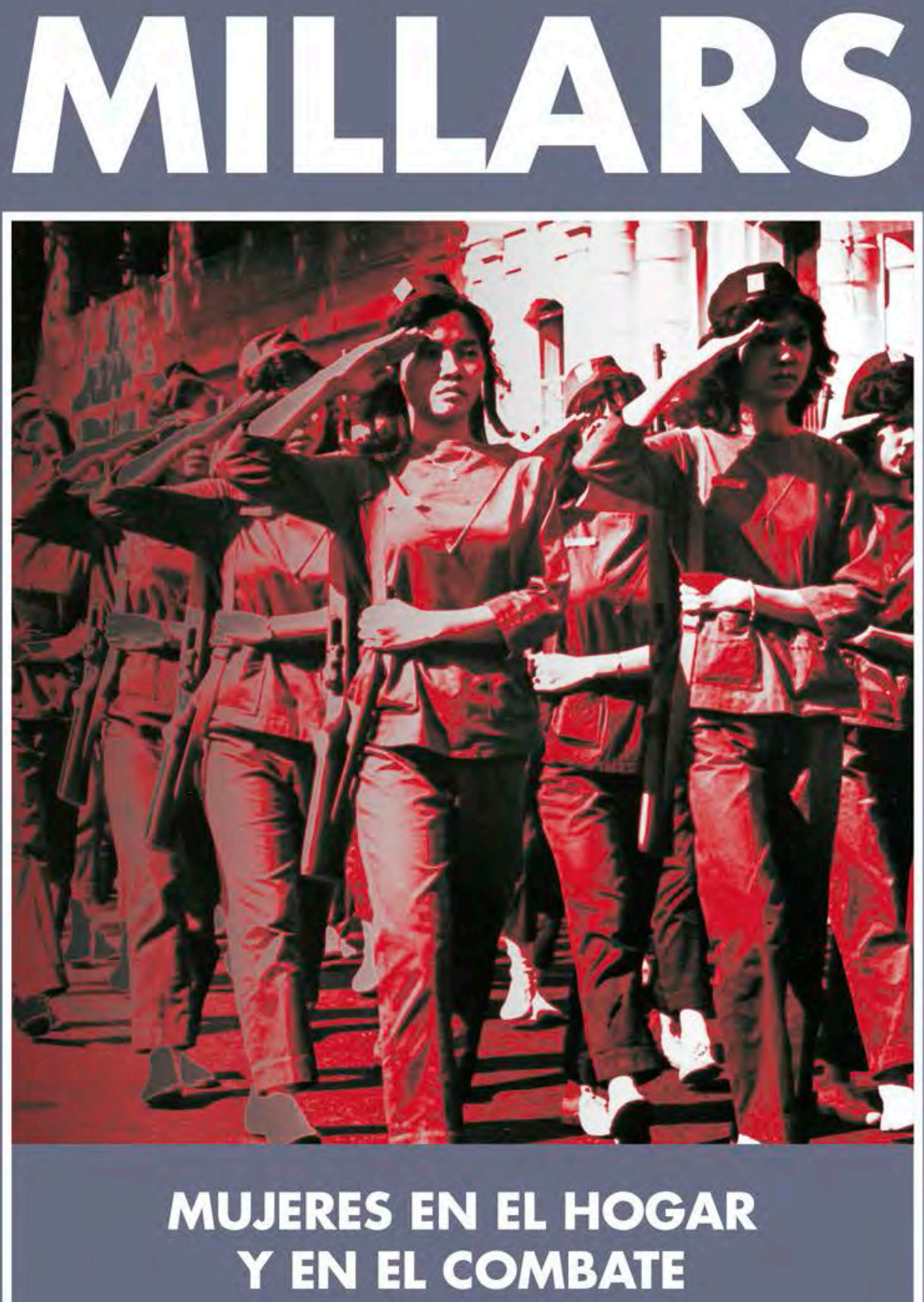

ESPAI I HISTÒRIA 



\section{UJI UANIERSTIAT}

XLVIII 2020/1

ESPAI I HISTÒRIA
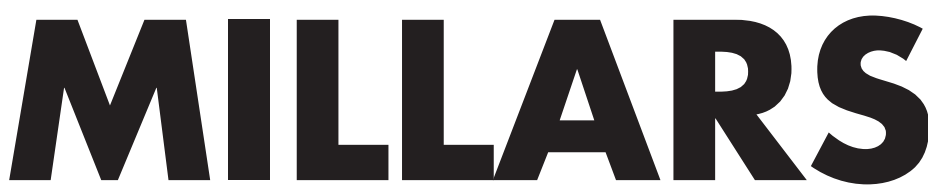

Departament d'Història, Geografia i Art 
REVISTA MILLARS. ESPAI I HISTÒRIA. -T. 1 (1974). -Castelló de la Plana:

Publicacions de la Universitat Jaume I, [1974]-

v.; $25 \mathrm{~cm}$

És continuació de: Millars

Descripció basada en: n.17 (1994)

ISSN 1132-9823

I.Universitat Jaume I (Castelló). Publicacions de la Universitat Jaume I

20 TOMO XLVIII $(2020 / 1)$

Director: Vicent Sanz Rozalén (Universitat Jaume I)

Secretaria: Cristina Igual Castelló (Universitat Jaume I)

\section{Consell de Redacció:}

Josep Benedito (Universitat Jaume I); Maria Bonet (Universitat Rovira i Virgili); Françoise Crémoux (Université Paris 8); Joan Manuel Marín (Universitat Jaume I); Carles Rabassa (Universitat Jaume I); Claudia Rosas (Pontificia Universidad Católica del Perú); Patricia Solis (Arizona State University)

\section{Consell Assessor:}

Pedro Barceló (Universität Postdam); Walther Bernecker (Universität Erlangen-Nüremberg); Aura Margarita Calle (Universidad Tecnológica de Pereira); Manuel Chust (Universitat Jaume I); Carmen Corona (Universitat Jaume I); Gloria Espigado (Universidad de Cádiz); Juan José Ferrer (Universitat Jaume I); Antoni Furió (Universitat de València); Paola Galetti (Università di Bologna); Antonio Gil Olcina (Universitat d'Alacant); Angeles González (Universidad de Sevilla); Robert Kent (California State University); Ana María Leyra (Universidad Complutense de Madrid); Clelia Martínez Maza (Universidad de Málaga); Víctor Mínguez (Universitat Jaume I); Enrique Montón (Universitat Jaume I); Inmaculada Rodríguez (Universitat Jaume I); Luis Sánchez Ayala (Universidad de Los Andes); Javier Soriano (Universitat Jaume I); Cècile Vincent-Cassy (Université Paris 13)

Millars. Espai i Història apareix indexada en els següents directoris i bases de dades:

- CARHUS Plus+ - CIRC (Clasificación Integrada de Revistas Científicas) - Díalnet - DICE (Difusión y Calidad Editorial de las Revistas Españolas de Ciencias Sociales y Jurídicas) - IN-RECS (Índice de impacto de Revistas Epañolas de Ciencias Sociales) - ISOC Índice Español de Ciencias Sociales y Humanidades (CSIC) - Latindex - MIAR (Matriu d'Informació per a I'Avaluació de Revistes) - RACO (Revistes Catalanes amb Accés obert) REGESTA IMPERII: Akademie der Wissenschaften und der Literatur - RESH (Revistas Españolas de Ciencias Sociales y Humanas) - Ulrich's

DOI: http://dx.doi.org/10.6035/Millars

http://dx.doi.org/10.6035/Millars.2020.48

Millars. Espai i Història no s'identifica necessàriament amb els continguts dels artícles publicats. Prohibida la reproducció total o parcial dels artícles sense l'autorització prèvia.

Dipòsit legal: CS-84-96

Disseny: Espai Paco Bascuñán-www.espaciopacobascunan.com

Impressió: Ulzama Digital www.ulzama.com

Foto de portada: Composició a partir de "Dones voluntàries paramilitars a l'escola militar a Saigón, 1963", Horst Faas/AP/REX/Shutterstock.

Aquest text està subjecte a una llicència Reconeixement-Compartirlgual de Creative Commons, que permet copiar, distribuir i comunicar públicament l'obra sempre que s'especifique l'autoria i el nom de la publicació fins i tot amb objectius comercials i també permet crear obres derivades, sempre que siguen distribuïdes amb aquest mateixa llicència. 


\section{Sumari}

\section{Dossier}

Elena Fernández y Manuel Santirso (Coords.)

Entre Hestia y Atenea. mujeres en el hogar

Y EN EL COMBATE

\section{Elena Fernández y Manuel Santirso}

Género y guerra, una encrucijada y una oportunidad

\section{Carlos Martínez Carrasco}

'A'isha bint Abī Bakr: mujer, guerra y poder en la Arabia paleo-islámica antes de la primera fitna

'A'isha bint Abī Bakr: woman, war and power in

Paleo-Islamic Arabia before the first fitna

\section{Francisco Ramiro Moya}

La participación femenina en los sitios de Zaragoza.

La percepción del mando militar y el interés

del poder político

Female participation in the sieges of Zaragoza.

The perception of the military command and the interest of political power.....

\section{Javier Hernández Ruano}

"Seremos hombres y fieras". Modelos, roles

y actitud de las mujeres durante el bloqueo y

asedio austracista de Peníscola (1706-1707)

"We will be men and beasts". Models, roles and

the attitude of women during the austracists blockade

and siege of Peníscola (1706-1707). 


\section{Adrian Shubert}

Agustina de Aragón in Cairo. Women warriors

and National Heroes in Global History

Agustina de Aragón en el Cairo. Mujeres guerreras

y héroes nacionales en la historia global.

\section{Matteo Morandini}

"Si pudiera convertirme en hombre". Género, política

y sociedad: la redefinición de lo femenino en

el largo 48 italiano

"If I could become a man". Gender, politics

and society: the redefinition of femininity during

the long 1848 in Italy

\section{Maila García Amorós}

La participación de la mujer en las distintas formas de resistencia durante la ocupación de Grecia por las fuerzas del Eje (1940-1944)

Women's participation in different forms of resistance during the occupation of Greece by the axis powers (1940-1944)

\section{Isabel García}

Las dinámicas de género en las brigadas femeninas

de la guerra siria

Gender dynamics in the women's brigades

of the Syrian war.

\section{Estudis}

\section{Pedro Castillo Palomares}

Las últimas giras de los bailes rusos de Diaghilev en España:

Barcelona (1924-1927)

The last tours of Diaghilev's russian dances in Spain:

Barcelona (1924-1927) 


\section{Dossier}

\section{Entre Hestia y Atenea. Mujeres en el hogar $y$ en el combate}

\section{Elena Fernández y Manuel Santirso \\ Coordinadores}

\section{Elena Fernández y Manuel Santirso}

Género y guerra, una encrucijada y una oportunidad

\section{Carlos Martínez Carrasco}

'A' isha bint Abī Bakr: mujer, guerra y poder en la Arabia paleoislámica antes de la primera fitna

\section{Francisco Ramiro Moya}

La participación femenina en los sitios de Zaragoza. La percepción del mando militar y el interés del poder político

\section{Javier Hernández Ruano}

"Seremos hombres y fieras". Modelos, roles y actitud de las mujeres durante el bloqueo y asedio austracista de Peníscola (1706-1707)

\section{Adrian Shubert}

Agustina de Aragón in Cairo. Women warriors and National Heroes in Global History

\section{Matteo Morandini}

"Si pudiera convertirme en hombre". Género, política y sociedad: la redefinición de lo femenino en el largo 48 italiano

\section{Maila García Amorós}

La participación de la mujer en las distintas formas de resistencia durante la ocupación de Grecia por las fuerzas del Eje (1940-1944)

\section{Isabel García}

Las dinámicas de género en las brigadas femeninas de la guerra siria 



\title{
GÉNERO Y GUERRA, UNA ENCRUCIJADA Y UNA OPORTUNIDAD
}

\author{
Elena Fernández \\ Universitat Autònoma de Barcelona \\ Manuel SantiRso \\ Universitat Autònoma de Barcelona
}

Como en tantos otros aspectos de nuestra cultura, toca remitirse a la Antigüedad clásica al ocuparse de los roles de género; no en vano estos son, ante todo y sobre todo, construcciones culturales. Por eso hemos puesto este dossier de Millars. Espai i Història bajo la doble advocación de Hestia, la diosa del hogar recluida voluntariamente en él, y de Atenea, la deidad armada y tutelar a la que los atenienses se encomendaban en sus luchas. De la una a la otra se despliega casi todo el abanico de los papeles asignados a las mujeres en los conflictos armados: sirvientes, administradoras, criadoras, educadoras, apoyos morales, reposos del guerrero o cantineras. Solo aparecen como combatientes de forma simbólica, como tótems: Atenea es una bandera, no un soldado.

Hay que reparar, a todo esto, en que tanto Hestia como Atenea eran vírgenes y hacían de esa condición un rasgo destacado y necesario de su personalidad. Afrodita parece quedar de fuera de juego aquí. Tal vez sea porque ni el amor ni el equilibrio, los principales atributos de esta tercera diosa, convienen a la guerra, aunque resulta más probable que se deba a que los otros papeles femeninos frente a la violencia armada, aquellos que se vinculan más directamente al cuerpo y a la sexualidad, no admiten ninguna poética. Nos referimos ahora a los de esclavas, prostitutas, rehe- 
nes, víctimas de violación, prendas de paz o varias de esas condiciones a la vez, estados que se ocultan o se lamentan, pero nunca se celebran. No hay que olvidar que hasta nuestros tiempos han sido hombres quienes han definido unos y otros roles, positivos y negativos, aplaudidos o silenciados, que al hacerlo y por simple oposición de contrarios han trazado los contornos de una masculinidad igualmente imaginada.

Quedaban -iquedan?- fuera de ese esquema las combatientes activas y en pie de igualdad, una conducta que solo se registraba entre bárbaros, gentes externas a la civilización. Así, las amazonas, probablemente inspiradas en las guerreras escitas, no deben ser vistas como un simple exotismo, sino que personifican la conducta femenina errónea, la anomalía y, otra vez en virtud de ese constante juego de espejos, revelan los temores masculinos. ${ }^{1}$

Aunque el recorrido del dossier que aquí presentamos no arranca en la Antigüedad, contempla buena parte de los papeles citados y desde luego se postula como una muestra representativa de todos ellos. No se hace en él un recorrido exhaustivo, ni cronológico ni geográfico (¿̇y cómo se podría?), pero sí se propone un nexo entre dos campos de la investigación histórica, las relaciones de género y los conflictos armados, que por fortuna han conocido una cierta expansión en los últimos tiempos. Desgraciadamente, a menudo ha faltado un diálogo intelectual sincero y productivo entre esas especialidades, una carencia que -jay!- mucho nos tememos que tenga que ver con posiciones ideológicas previas. Quienes cultivamos la polemología, siquiera de forma ocasional, sabemos que la guerra constituye un excelente test histórico: su misma naturaleza de experiencia límite pone al descubierto, y a menudo con gran crudeza, claves de comprensión social que suelen quedar veladas en tiempos de paz. Esa prueba del 9 combinada debería enseñar mucho a historiadores e historiadoras, más en unos tiempos y un país en que -confesamos ignorar por qué- las estudiantes han decidido frecuentar menos las aulas de Historia.

En síntesis, los trabajos contenidos en este dossier examinan la implicación del sexo biológico y de los roles tradicionales de género en las narrativas históricas que han tematizado la guerra y su retaguardia. Los artículos aquí recogidos van más allá de la ficción histórica que ha acompañado a la

1 Véanse al respecto ENCINAS, $M^{a}$ Carmen, "La visión trágica de la mujer en la guerra" y GONZÁLEZ MAESTRE, Cristina, "Siempre hemos luchado: la invisibilización de la mujer guerrera en la historiografía y arqueología de la Grecia antigua", ambos en SANTIRSO, Manuel y GUERRERO, Alberto (eds.) (2019), Mujeres en la guerra y en los ejércitos, Catarata, Madrid. 2019. Este volumen colectivo contiene muchas otras aportaciones de interés, relativas a diversas épocas y lugares. 
presencia femenina en tiempos de conflicto y que ha tendido a perpetuar los papeles tradicionales de los hombres como guerreros y de las mujeres como asistentas y cuidadoras. Se trata, dicho de otro modo, de poner en tela de juicio la dualidad forzosa Ares/Hestia. Trabajos como los aquí planteados muestran que la interrelación de las mujeres y la guerra ha sido mucho más compleja que una simple dicotomía como esa. Si bien es cierto que mayoritariamente los hombres han luchado y liderado los ejércitos, resulta mucho más cuestionable que se tenga que considerar a las mujeres como el "sexo pacífico" del que hablaba Margarete Mitscherlich. ${ }^{2}$ Por suerte, como muestra esta colección de escritos, las relaciones de las mujeres con la guerra son un campo de estudio en crecimiento no sólo en la disciplina histórica sino también en la literatura o el arte, e incluso ha ganado espacio en aquellas materias que analizan los debates políticos.

Los ocho artículos que componen este dossier conforman una serie cronológica con un relato conjunto claro: por un lado, la guerra como suceso no segrega por sexo, y por el otro, el alcance de sus consecuencias no es ajeno a hombres ni a mujeres. Comenzando en la antigüedad y llegando hasta a nuestros días, en estos textos se da buena cuenta de que las experiencias registradas son variopintas. Cada aportación trata sobre una guerra específica en el tiempo y en el espacio. Por ello, hemos organizado las contribuciones siguiendo el sencillo criterio del orden cronológico.

El primero de los títulos nos traslada a la Arabia del s. VII, que tampoco está culturalmente tan lejos de la Antigüedad clásica. En él se aborda la figura de 'Ā'isha bint Abi Bakr. más allá de su significación como esposa de Muhammad y su relevancia en el proceso de fortalecimiento de la cultura islámica. Desde una perspectiva poco conocida, Carlos Martínez Carrasco, se aproxima al personaje para descubrirnos su relación con la guerra y con la política del incipiente islam en sus tres primeros califatos. En un momento en que para las mujeres comunes estaba vetado el espacio público, "A' isha formó parte de ese grupo restringido de "reinas y princesas" cuyo protagonismo resultaría fundamental en los acontecimientos políticos y culturales del pasado. En consecuencia, este trabajo nos señala su implicación en las campañas dirigidas por Muhammad, pero también en las posteriores conquistas. A partir de fuentes de mediados del siglo VIII y de

2 MITSCHERLICH, Margarete (1987), The Peaceable Sex: On Aggression In Women And Men, Fromm, Nueva York. 1987. 
la primera mitad del $X$, el texto se detiene en los escenarios que llevaron a esta mujer de una posición pasiva a una de influencia en la esfera política y militar, incluso a pesar de la falsa acusación de adulterio que lanzaron contra ella y que reveló un aspecto determinante de las guerras tribales en la Arabia pre-islámica: el uso de la poesía satírica como arma política y de la mujer como objeto literario. Como se sabe, la virginidad de Hestia sufrió muchos asaltos.

En esta línea, la construcción de la imagen de mujer guerrera también ha sido materia de estudio en el trabajo de Javier Hernández Ruano. A partir de las crónicas y escritos propagandísticos surgidos en el contexto de la Guerra de Sucesión, el autor señala como la publicística de guerra diluyó los roles de género vigentes en aras de una causa superior. Sin duda, toda guerra de pluma trata de sugestionar o de persuadir a la población mediante de los acontecimientos de armas, y por supuesto así lo muestra este artículo cuando se detiene en los hechos que acompañaron al bloqueo de Peníscola durante la contienda. Entonces, los triunfos de sus vecinos desencadenaron una ingente producción de literatura dirigida a explotar la gloria de las mujeres de la localidad. En este punto, resulta sugestivo cómo el texto analiza las causas por las que la significación de las vecinas de Peníscola, sobre todo en las labores logísticas durante el sitio, desembocaron en una serie de representaciones de la feminidad, destinadas a perdurar en la memoria colectiva mediante la pervivencia de una imagen idealizada de mujer guerrera. Un nuevo tótem, ahora moderno.

Sobre la popularización de estos modelos femeninos idealizados trata el artículo de Adrian Shubert. Situado en el contexto de la Guerra de Independencia en la España de comienzos del siglo XIX, centra su atención en la construcción y magnificación del mito de una de sus heroínas más emblemáticas: Agustina de Aragón. Es sabido que la fama de Agustina-de esta Atenea española, salvando las distancias- no se limitó a las fronteras españolas. Lord Byron le dedicaría alabanzas y su compatriota David Wilkie pintaría sus hazañas en 1828. Dada la participación británica en la guerra contra Napoleón, estos homenajes podrían esperarse. Más sorprendente es lo que Shubert nos descubre en su artículo. Partiendo del culto a los héroes como parte indispensable en la construcción de identidades nacionales, el autor explora la fascinación por la española desde un marco aún más amplio: Agustina aparece como un icono que trascendió más allá de su tiempo y de las fronteras de Occidente. Para ello, el autor reflexiona sobre cuáles son los aspectos de las hazañas de Agustina más susceptibles de ser compartidos y los que eran específicos del contexto local. Shubert lo muestra mediante un recorrido por el proceso que encumbró a la aragonesa como heroína universal y que mantuvo a su figura perenne en el tiempo. 
Sin embargo, no hay que olvidar que antes de convertirse en una heroína nacional, Agustina de Aragón no fue más que una de tantas entre las muchas mujeres que intervinieron activamente en la defensa de Zaragoza. ${ }^{3}$ Sin duda, la pronta trascendencia de su figura y su representación constante en los medios oficiales y populares, ensombrecieron la memoria de esas otras luchadoras que también defendieron la capital aragonesa de las tropas francesas. Precisamente, Ramiro Moya propone recuperar el papel desarrollado por esas mujeres, el tipo de acciones en las que tomaron parte y sus vivencias durante y después de la contienda. Asimismo, el autor reflexiona sobre las posibles razones que impulsaron la movilización femenina y se pregunta acerca de las motivaciones de las propias protagonistas y de sus mandos militares.

El año 1848 es claramente un punto de inflexión histórico, aunque en general se le ha prestado poca atención para las materias que se abordan en este dossier. No obstante, y como defiende Matteo Morandini, tuvo lugar en ese momento una explosión de las reivindicaciones civiles, nacionales y sociales sin precedentes. El asentamiento de la prensa y de la lectura aumentaron la celeridad en la trasmisión de las noticias y la inmediatez en el desarrollo de los sucesos históricos. De pronto, la propagación de su mensaje a las masas se convirtió en esencial, tanto para los liberales como para los círculos reaccionarios. En ese contexto, el debate en torno a lo femenino y la familia alcanzó una extrema importancia en la Italia del bienio revolucionario. La cuestión que estaba en el aire no era otra que su papel en la nueva sociedad burguesa italiana. En tanto que trasmisoras de valores y preceptoras de los futuros ciudadanos, las mujeres italianas se convirtieron en objeto del adoctrinamiento religioso, pero también del discurso nacional-patriótico. Hestias, ante todo. Gracias al estudio comparativo entre la producción cultural patriótico democrática y la reaccionaria -memorias, iconografía y literatura-Morandini nos expone el choque, pero también la coincidencia entre el nacionalismo y las fuerzas clericales en su visión de la feminidad, así como la influencia de esta concepción en áreas estratégicas de la sociedad como la familia, la educación y la sexualidad. Hace tan solo unos años se reeditaba el magnífico libro Partisanas. La mujer en la resistencia armada contra el fascismo y la ocupación alemana (1936-1945). ${ }^{4}$ Se trata de una obra notable que sin duda marcó un antes

3 FERNÁNDEZ GARCíA, Elena (2009), Mujeres en la Guerra de la Independencia, Sílex, Madrid. 2009.

4 STROBL, Ingrid (2015), Partisanas. La mujer en la resistencia armada contra el fascismo y la ocupación alemana (1936-1945), Virus Editorial, Barcelona, (1ª ed. 1996). 
y un después al poner en valor el papel de las mujeres en la lucha contra el fascismo. Por suerte, desde su primera edición, hace ya casi 25 años, las revisiones historiográficas sobre la Segunda Guerra Mundial han continuado rescatando y evaluando la contribución de las mujeres en la consecución de la victoria sobre las tropas del Eje. Gracias a trabajos como éste ahora sabemos que fueron muchas las mujeres que tomaron las armas o colaboraron en las estructuras de resistencia. Hubo más amazonas y guerreras escitas de lo que sabíamos o deseábamos saber. Ahora bien, como revela Maila García Amorós en el caso de la Grecia ocupada, la mayoría de ellas tuvieron que enfrentarse a su vez a las diversas organizaciones revolucionarias y a sus compañeros militantes. Como consecuencia de la autoridad de la Iglesia Ortodoxa y del predominio de una visión patriarcal de la sociedad, a la gran mayoría de estas mujeres no se las llegó a considerar, salvo notables excepciones, como iguales y se las ubicó en la retaguardia. Sin embargo, como expone la autora, fue precisamente allí, alejadas de la lucha directa y en la clandestinidad antifascista, donde las griegas tuvieron un papel relevante. En definitiva, y así nos lo confirma el texto de García Amorós, las mujeres griegas que se opusieron a la ocupación tuvieron que encarar una doble lucha: como mujeres y como resistentes.

Cerramos el círculo volviendo al espacio árabe casi catorce siglos después. Hoy seguimos inmersos en la guerra civil que enfrenta, entre otros, al régimen de Bashar al-Asad y a los rebeldes desde que las protestas de la llamada Primavera Árabe alcanzaran Siria en 2011 . Desde entonces, a ese conflicto se han unido la lucha contra el Estado Islámico y una serie de enfrentamientos discontinuos entre potencias externas que, como los Estados Unidos, Rusia, Irán o Turquía, se han involucrado en la contienda por motivos geopolíticos. Por todo ello, y con el paso del tiempo, la realidad de los combates en Siria se ha vuelto cada vez más intrincada, y sobre todo más peligrosa para la población civil. ${ }^{5}$ Actualmente nos encontramos ante una clara catástrofe humanitaria en la que, tanto las tropas del Gobierno sirio como las milicias aliadas y grupos rebeldes, han violado y atacado a innumerables mujeres, jóvenes y niñas, dentro de una cruzada de escarmiento contra comunidades rivales. En este contexto, la finalidad del trabajo de Isabel García consiste en llevar a cabo una comparación sistemática entre las principales organizaciones que libran la guerra en Siria. El propó-

5 "I lost my dignity": Sexual and gender-based violence in the Syrian Arab Republic, The Independent International Commission of Inquiry on the Syrian Arab Republic, ONU [ref. el 23 marzo 2018] (https://www.ohchr.org/Documents/HRBodies/HRCouncil/ColSyria/A-HRC-37-CRP-3. pdf). 
sito de su estudio es localizar los motores que impulsan una incorporación femenina cada vez mayor en las protestas y la lucha activa. Pasando desde las organizaciones yihadistas como el Dáesh hasta la insurgencia kurda e incluso el ejército republicano, la autora nos expone las razones, subjetivas y objetivas, que explicarían la formación de las brigadas femeninas en una sociedad que se rige por unas costumbres claramente conservadoras en relación al sexo femenino.

¿Se trata de un cambio temporal que obedece a la pura necesidad del momento? ¿ Ocurrirá como con las dos guerras mundiales del siglo XX, sobre cuya importancia para la emancipación femenina aún se debate? ¿Las mujeres combatientes en pie de igualdad han venido para quedarse? Los días confinados como los que atravesamos al escribir estas líneas deberían enseñarnos que no podemos imaginar el futuro por simple extrapolación. En el cambio histórico, que es el objeto de nuestro oficio, hay azar, avances y retrocesos, y si alguna lección queda clara es que las conquistas que no se defiende, se pierden. Y valga, porque aquí toca, el símil bélico. 



\title{
'Ā'ISHA BINT ABĪ BAKR: MUJER, GUERRA Y PODER EN LA ARABIA PALEO-ISLÁMICA ANTES DE LA PRIMERA FITNA
}

\author{
'A' ISHA BINT ABĪ BAKR: WOMAN, WAR AND POWER \\ IN PALEO-ISLAMIC ARABIA BEFORE THE FIRST FITNA
}

Carlos Martínez Carrasco

Universidad de Granada

\section{RESUMEN}

Este estudio se orienta hacia la parte menos conocida de la vida de 'A' isha bint Abī Bakr, la de los años previos a la guerra civil. Me centro en su relación con lo militar en el contexto de las guerras que dieron paso al nacimiento del islam como entidad política. Y lo hago tomando como eje tres momentos en los que ella aparece como protagonista directa o indirecta, y en este último caso saltando las barreras sociales. Una 'A' isha más cercana a una "señora de la guerra" que a una matrona musulmana.

Palabras clave: Edad Media, Paleo-islam, Arabia, Califato, 'A' isha

\section{ABSTRACT}

This study deals with the lesser known part of the life of ' $\bar{A}$ ' isha bint Abī Bakr, namely the years prior to the civil war. I focus on her relationship with the military in the context of the wars which led to the birth of Islam as a political entity. The study revolves around three moments in which she appears as a direct or indirect protagonist, and in this last case overcoming social barriers. An ' $\overline{\mathrm{A}}$ ' $\mathrm{i}$ sha closer to a "lady of war" than a Muslim matron.

Keywords: Middle Age, Paleo-islam, Arabia, Caliphate, 'A' isha 


\section{RESUM}

\section{A' ISHA BINT ABĪ BAKR: DONA, GUERRA I PODER A L' ARÀBIA PALEO-ISLÀMICA ABANS DE LA PRIMERA FITNA}

Aquest estudi s'orienta cap a la part menys coneguda de la vida ' $\bar{A}$ 'isha bint $A b i ̄$ Bakr, als anys previs a la guerra civil. Em centre a la seua relació amb l'àmbit militar al context de les guerres que van donar pas a l'islam com a entitat política. I ho faig prenent com a eix tres moments en els quals ella apareix com a protagonista directa $o$ indirecta, $i$ en aquest darrer cas saltant les barreres socials. Una 'A' isha més propera a una "dona de la guerra" que a una matrona musulmana.

Paraules clau: Edat Mitjana, Paleo-islam, Aràbia, Califat, 'A' isha. 
' $\bar{A}$ 'isha bint Abī Bakr es una figura fundamental en el islam por su papel como transmisora de la tradición religiosa: muchos hadîthes la citan como fuente de autoridad.' Pero se trata de un personaje con aristas y claroscuros, denostada por su actuación política, que describen con el término árabe bid'a (=innovación), un sinónimo de herejía en el mundo islámico. ${ }^{2}$ Como esposa de Muhammad fue testigo de excepción de las guerras que éste sostuvo contra los qurayšíes por hacerse con el control de La Meca. Más tarde, como su viuda, ella misma se convirtió en parte activa en la primera fitna que sacudió el califato entre 656-661, terminando así con la edad de oro mítica del islam primitivo.

1 BARLAS, Asma (2002), "Believing women" in Islam. Unreading Patriarchal Intrepretations of the Qur'ān, University of Texas Press, Austin, p. 46; SHAIKH, Sa'diyya (2004), "Knowledge, Women and Gender in Hadith: a Feminist Interpretation", Islam and Christian-Muslim Relations, vol. 15:1, pp. 99-108, espec. 100; y GEISSINGER, Aisha (2011), "'A'isha bint Abi Bakr and Her Contributions to the Formation of the Islamic Tradition", Religion Compass, vol. 5:1, pp. 37-49, espec. 40.

2 MERNISSI, Fátima (1999), El harén político. El Profeta y mujeres, Ediciones del Oriente y del Mediterráneo, Madrid, p. 16; PETERS, Francis E. (2007), Los hijos de Abraham. Judaísmo, Cristianismo, Islam, Laertes, Barcelona, p. 69; y EL CHEIKH, Nadia Maria (2015), Women, Islam, and Abbasid Identity, Harvard University Press, Cambridge, Massachusetts/Londres, p. 106. 
La mayoría de los estudios que, como los de Denise A. Spellberg, han abordado la dimensión política y militar de 'A' isha lo hacen tomando como eje la batalla del Camello o de Basora (656), por la rareza que representa el hecho de que una mujer se pusiera al frente de un ejército, si bien la historia de los árabes ofrece ejemplos de reinas guerreras como Mavia en el siglo IV d.C. ${ }^{3}$ No obstante, en este estudio me propongo abordar su relación con la guerra antes de ese acontecimiento; su implicación en las campañas dirigidas por Muhammad, pero también en las posteriores conquistas, donde trataré de dibujar la línea que le llevó de ser un elemento pasivo a participar de manera activa en la vida política y militar del primer islam. En esta evolución intentaré determinar el impacto que tuvo la falsa acusación de adulterio que lanzaron contra ella y que revistió un aspecto determinante de las guerras tribales en la Arabia pre-islámica: la propaganda a través de la poesía.

Lamentablemente, no tenemos ningún documento escrito por la propia ' $\overline{\mathrm{A}}$ ' $\mathrm{i}$ sha en el que ella exprese su visión, por lo que nos vemos obligados a (re) construirla a través de interpretaciones masculinas que en ocasiones han tergiversado su figura con el fin de adaptarla a las necesidades del discurso dominante vigente cuando se compusieron. En este estudio, parto de las fuentes islámicas más tempranas escritas entre mediados del siglo VIII y la primera mitad del $X$, cuando se está poniendo por escrito la memoria de lo sucedido durante el período pre-islámico y paleo-islámico; una memoria construida en virtud de las necesidades de legitimación de la dinastía 'Abbāsí. Hay que tener en cuenta este aspecto para abordar de manera crítica la imagen, no siempre positiva, de una mujer que puso en entredicho la hegemonía masculina en el campo político-militar.

\section{Testigo de la guerRa: espacio privado-femenino VS. Espacio público-mas- CULINO}

El primer contacto de ' $\overline{\mathrm{A}}$ 'isha con la guerra y lo militar del que tenemos noticia es la batalla de al-Khandaq (=el Foso), en el año $5 \mathrm{AH}$ (ca. 627), de la que fue testigo. Ella, junto al resto de mujeres de los musulmanes y sus hijos, fue enviada a los fuertes de Medina en el momento en el que aparecieron los judíos medineses y sus aliados mecanos. ${ }^{4}$ Era una batalla

3 SOTO CHICA, José (2019), "Señoras de la guerra en la Alta Edad Media: el caso de la reina Mavia", en SANTIRSO, Manuel y GUERRERO, Alberto (coords.), Mujeres en la guerra y los ejércitos, Libros de la Catarata, Madrid, pp. 79-90.

4 Ibn Isḥāq, Sïrāt, p. 453 [GUILLAUME, Alfred $\left(2004^{17}\right)$, The Life of Muhammad. A translation of Ibn Isḥāq's Sīrāt Rasūl Allāh, Cambridge University Press, Oxford/Nueva York]. 
desigual, si atendemos a las cifras que dan los tradicionistas musulmanes: diez mil aliados contra tres mil musulmanes. ${ }^{5}$ Se trató un sitio en toda regla, si nos atenemos a la descripción que ofrece lbn Isḥāq, lo cual casa mal con la imagen de los guerreros árabes pre-islámicos y aquéllos que protagonizaron la conquista, descritos como un grupo indisciplinado, carente de formación militar y mal armado: "El Apóstol [i.e. Muhammad] y los politeístas permanecieron más de veinte días, cerca de un mes, sin luchar, excepto por algunos disparos de arco y el sitio". 6 El ejército enemigo había sido detenido por los fosos que mandó construir un Muhammad que el año anterior, $4 \mathrm{AH}$ (ca. 625-626), fue derrotado en la batalla de Uhud y necesitaba un golpe de efecto que le devolviera a los musulmanes la confianza en él y su mensaje.

Como reconocerían sus enemigos, esta táctica era algo nuevo entre los árabes, habituados a los choques frontales entre los grupos tribales. ${ }^{7} \mathrm{Se}$ trataba de una innovación que respondía a otros usos de la guerra que al parecer eran ajenos a la península arábiga. Todos señalan que la idea de cavar trincheras fue idea de Salmān al-Fārisi (=el Persa) con la que la comunidad entera estuvo de acuerdo. Incluso el propio Muhammad trabajó en las trincheras como uno más. ${ }^{8}$

Desde el fortín de los Banū Ḥāritha, el mejor protegido de Medina, ${ }^{9}$ 'A' isha tal vez fuera testigo del combate singular que mantuvieron 'Alī ibn $A b \bar{i}$ Țālib, primo y yerno de Muhammad, y 'Amr ibn 'Abdu Wudd, paladín de los mecanos. Desde allí también podía ver cómo Khālid ibn al-Walīd y 'Amr ibn al-'Ās comandaban la caballería de los politeístas y causaban numerosas bajas a los musulmanes. Curiosamente, es un tradicionista como Ibn Sa'd quien convierte a estos dos emires en personajes principales del episodio de al-Khandaq, ${ }^{10}$ sobre todo teniendo en cuenta el papel que tendrían a posteriori como los principales artífices de las conquistas de las provincias romanas y persas y la consolidación del califato.

5 Ibn Sa'd, Tabaqāt, ii. 1, p. 81 [MOINUL Haq, S. (1990), Ibn Sa'd's Kitab al-Tabaqat al-Kabir, vol. II, parts I \& II, Kitab Bhavan, Nueva Delhi].

6 Ibn Isḥāq, Sīrāt, p. 454.

7 Ṭabarī, Ta'rīkh, viii, p. 18 [FISHBEIN, Michael (1997), The History of al-Tabarī. Vol. 8: The Victory of Islam, SUNY, Nueva York]; Ibn Isḥāq, Sïrāt, p. 454.

8 Ibn Sa'd, Tabaqāt, ii. 1, p. 81.

9 Ibn Isḥāq, Sīrāt, p. 457.

10 Ibn Sa'd, Țabaqāt, ii. 1, pp. 84-85. 
El duelo entre 'Alī y 'Amr reviste detalles que recuerdan a la llíada de Homero. Sin embargo, sería éste una variante árabe del mard-o-mard, el combate entre dos hombres iguales, propio de la cultura caballeresca persa sasánida. ${ }^{11}$ Los árabes no fueron ajenos a los usos militares de los dos grandes Imperios, el romano y el persa. De este modo, de 'Amr se dice que "llegó portando signos distintivos de su rango", 12 lo que indicaría una jerarquía que iba más allá de lo tribal y avanza la posibilidad de una organización militar. Al ser una fuente escrita poco después de la Revolución 'Abbāsí, con Ibn Isḥāq quizás no sirvan las precauciones de las que hablaba $\mathrm{H}$. Kennedy para negar que existiera alguna estructura en los primeros ejércitos islámicos, achacándolo todo a un anacronismo de los tradicionistas, que proyectaban la realidad de su época al pasado idealizado. ${ }^{13}$

Igualmente importante es la mención a cómo se presentó 'Alī. Según la descripción que ofrece Ibn Isḥāq: "se levantó vestido con la armadura y le pidió permiso al Profeta para luchar contra él ['Amr]" ${ }^{14}$ Teniendo en cuenta que este mismo autor menciona de manera particular las cotas de malla, es posible que lo que vistiera fuera una de esas armaduras laminadas, al estilo romano-persa. Después de todo, 'Alī pertenecía a la aristocracia mecana y serían hombres como él, con cierta riqueza, los que podían costear la adquisición y el mantenimiento de este equipo. Se podría pensar que estos artículos llegaron al Hidjāz a través del comercio o fruto del pillaje en el limes romano o persa. No obstante, hay que suponer la existencia de armeros locales. El que sería el segundo califa del islam, 'Umar ibn alKhatțāb (634-644), señala cómo la armadura de lbn 'Abdu Wudd era "la mejor que podía encontrarse entre los árabes". ${ }^{15}$ No obstante, la tradición que transmite lbn Sa'd se presenta mucho más islamizada, más acorde con lo que se suponía debía ser el "espíritu del islam primitivo", describiendo cómo Muhammad dio su espada a "Alī y lo encomendó a Dios para que le diera la victoria sobre un 'Amr de noventa años. ${ }^{16}$ ¿ Una metáfora de la lucha entre lo nuevo - el islam - y lo viejo - el politeísmo-?

11 CHRISTENSEN, Arthur (1944), L'Iran sous les Sassanides, Ejnar Munksgaard, Copenhague, p. 216; y FARROKH, Kaveh (2007), Shadows in the Desert. Ancient Persia at War, Osprey Publishing, Oxford/Nueva York, pp. 180-181.

12 Ibn Isḥāq, Sïrāt, p. 455.

13 KENNEDY, Hugh (2001), The Armies of the Caliphs: Military and Society in the Early Islamic State Warfare and History, Routledge, Londres/Nueva York, p. 3.

14 Ibn Isḥāq, Sïrāt, p. 455.

15 Ibn Isḥāq, Sīrāt, p. 456.

16 Ibn Sa'd, Tabaqāt, ii. 1, p. 83. 
'Amr descendiendo del caballo que montaba a petición de 'Alī, para poder luchar ambos a la misma altura. El paladín musulmán parando el golpe de espada que le lanza su rival. El arma que queda embotada en el escudo del rival. El contraataque de 'Alī que derriba a su oponente de un golpe en el cuello. El cuerpo sin vida de 'Amr que cae levantando una enorme polvareda. En otras versiones, es el polvo que se levanta, providencial, lo que ayuda en su victoria al campeón musulmán. ${ }^{17}$ El grito de "Allah Akbar" que profiere Muhammad cuando ve que el resultado del duelo es el esperado y su primo y yerno sigue con vida. La reconvención que le hace 'Umar a 'Alī por no haber despojado a 'Amr de sus armas. La respuesta que le da, justificándose en que eso no era digno. ${ }^{18}$ Es una escena que bien podía haber salido de la llíada homérica o de la Eneida de Virgilio, pero que entronca con los ideales caballerescos de los que hacen gala los poetas-guerreros árabes de las mu allaqāt, la poesía pre-islámica, compuestas en su mayoría en el entorno cortesano de al-Ḥīra, la capital de los Banū Lakhm, aliados de la Persia sasánida. ${ }^{19} Y$ curiosamente, es Ibn Ishāa quien se recrea en todos estos detalles, dejando entrever que el público potencial de su obra estaba familiarizado con estos valores militares. Se contrapone a la parquedad que observamos en el relato de al-Ṭabarī, mucho más seco y carente de épica, ${ }^{20}$ quizás porque el tiempo de los 'Abbāsíes estaba marcado por otro tipo de códigos.

Uno de esos cambios tuvo que ver con el hidjāb, la cortina que debía separar a las mujeres de los varones. El momento en que pasó a ser obligatorio, marcó la separación entre hombres y mujeres dentro de la Umma, la comunidad islámica. ${ }^{21}$ Pero su uso aún no estaba vigente cuando tuvo lugar la batalla del Foso y así lo dice la propia ' $\bar{A}$ ' isha cuando relata la entrada en el torreón de los Banū Ḥāritha de Sa'd ibn Mu'āth, cuya madre era una de las musulmanas que se refugiaron con la joven esposa del Profeta. ${ }^{22} \mathrm{De}$ acuerdo con la tradición que se le atribuye a ella misma, Sa d entró en las estancias donde estaban las mujeres para armarse con una cota de malla, pero ésta era demasiado corta para cubrirle por completo el cuerpo; herido por una flecha que le seccionó la vena mediana del brazo, moriría en

17 Ibn Sa'd, Tabaqāt, ii. 1, p. 83.

18 Ibn Isḥāq, Sīrāt, p. 456.

19 CORRIENTE, Federico y MONFERRER, Juan Pedro (2006), Las diez mu allaqāt. Poesía y panorama de Arabia en vísperas del Islam, Hiperión, Madrid.

20 Tabarī, Ta'rīkh, viii, pp. 18-19.

21 MERNISSI, Harén, p. 185.

22 Ibn Isḥāq, Sìrāt, p. 457; Ṭabarī, Ta'rīkh, viii, p. 19. 
combate. ${ }^{23}$ Esta entrada en el espacio femenino, será interpretada posteriormente por la tradición islámica, en época 'abbāsí, como una violación de un mundo que debía estar vedado a los hombres - salvo los eunucos, los únicos capacitados para estar con ellas-. No obstante, no hay una censura de este comportamiento. Son aún las costumbres de la diāhiliyya, el tiempo de la ignorancia.

Pero hay otras tradiciones, posteriores, que le dan al episodio un aire más caballeresco, más del gusto de la corte de los 'Abbāsíes, aunque también tengan por transmisora a la propia ' $\bar{A}$ 'isha. El escenario en el que se desarrolla la acción es un jardín amurallado por el que estaba paseando la esposa del Profeta. Según cuenta ella misma, en el momento de la batalla, había salido afuera siguiendo a los hombres cuando pasó junto a ella Sa'd ibn Mu'āth, armado con la cota de malla corta, acompañado por su sobrino al-Hārith ibn Aws, que le sujetaba el escudo. ${ }^{24} \mathrm{El}$ tradicionista está dibujando un espacio que difícilmente se correspondería con el de la Medina de estos primeros años del islam, con una fortaleza a la que estaba adherido un jardín para el deleite de quienes vivían en ella. No obstante, este espacio ajardinado se presta mucho mejor para la historia que se desarrollará, que no una torre de adobe en mitad de un oasis.

En el interior de ese jardín amurallado, asistió 'A' isha a la escena principal de lo que podríamos llamar el Cantar de al-Khandaq, que tiene como protagonista a 'Umar ibn al-Khaț̣āb y a un misterioso guerrero cuyo rostro estaba cubierto por un tasbighah, la cota de malla que se acoplaba al casco y que sólo permitía ver los ojos. ${ }^{25}$ Se trataba de un armamento que habría empezado a usarse a partir de las reformas militares de Cosroes I, en la segunda mitad del siglo $\mathrm{Vl} .{ }^{26} \mathrm{Es}$ una estampa que recuerda mucho a esos guerreros persas sasánidas esculpidos en los bajorrelieves de Tagh-e-Bostan. En este caso sí podemos sostener las reticencias de H. Kennedy sobre la veracidad o no de la existencia de este tipo de caballeros armados "a la sasánida".

Podría ser una invención del tradicionista en favor de su relato. Era necesario mantener en secreto la identidad del guerrero que debe salir en defensa de la dama. Descubierta 'A' isha por 'Umar, el futuro califa la reprende por

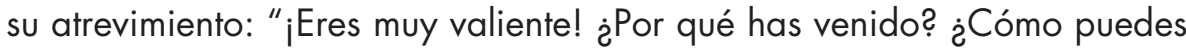

23 Ibn Isḥāq, Sīrāt, p. 457; Ṭabarī, Ta'rīkh, viii, p. 20.

24 Ṭabarī, Ta'rīkh, viii, p. 21

25 Tabarī, Ta'rīkh, viii, p. 21.

26 FARROKH, Shadows, p. 231. 
saberlo?". ${ }^{27}$ Es de sobra conocida la animadversión que lbn al-Khațāāb sentía por la joven esposa de Muhammad; la tradición siempre lo presentará como un rigorista al que ' $\bar{A}$ ' isha deja con frecuencia en evidencia delante del resto de la Umma. En medio de este altercado es cuando se produjo la revelación de la identidad del misterioso guerrero: Talḥa ibn 'Ubayd Allāh, que reprende a 'Umar por haber hablado demasiado. ${ }^{28} \mathrm{Es}$ uno más de una larga lista de incidentes que tienen como protagonistas a Ibn al-Khațāa y las mujeres del Profeta, por la libertad de la que éstas gozaban y que ponían en peligro los equilibrios sociales, por más que en el Corán se insista en que deben estar recluidas y ser modestas. ${ }^{29}$ 'Umar tenía miedo a una rebelión por parte de las musulmanas, que quisieran imitar la conducta de las mujeres de Muhammad o de las medinesas. ${ }^{30}$

La tradición islámica ha querido que en este momento Ṭalha se enamorara de la joven esposa del Profeta. ${ }^{31}$ Pero este hombre, pariente de Abū Bakr, pasa por ser uno de los primeros en aceptar el islam y a Muhammad como el Enviado de Dios, ${ }^{32}$ lo que lo convertía en miembro de la primera aristocracia islámica propiamente dicha. No obstante el enfrentamiento Talha-'Umar no se quedará ahí: Talhạa recriminó a Abū Bakr que nombrara como sucesor a un hombre como 'Umar, famoso por su rigorismo y el miedo que inspiraba en su pueblo. ${ }^{33}$

27 Ṭabarī, Ta'rïkh, viii, p. 21

28 Ṭabarī, Ta'rïkh, viii, p. 21.

29 GEISSINGER, "'A'isha", p. 39

30 SPELlBERG, Denise A. (1991), "Political Action and Public Example: 'A'isha and the Battle of Camel", en KEDDIE, Nikki E. y BARON, Beth (eds.), Women in Middle Eastern History. Shiffing Boundaries in Sex and Gender, Yale University Press, Londres/New Haven, pp 45-57, espec. 47; y MERNISSI, Harén, pp. 163-165.

31 ABBOTT, Nabia (1942), Aishah, the beloved of Muhammad, University of Chicago Press, Chicago, p. 58.

32 DONNER, Fred M. (2010), Muhammad and the Believers. At the Origins of Islam, Harvard University Press, Cambridge/Londres, Massachusetts/Londres, p. 42.

33 Țabarī, Ta'rikh, xi, p. 153 [BLANKINSHIP, Khalid Yahya (1993), The History of al-Tabarī. Vol. 11: The Challenge to the Empires, SUNY, Nueva York]. 


\section{LA GUERRA POR OTROS MEDIOS: EL CUERPO FEMENINO COMO ARMA Y LA PROPA- GANDA}

Fue en el mes de sha'bān del $6 \mathrm{AH}$ (ca. diciembre 627) ${ }^{34}$ cuando los musulmanes liderados por su Profeta partieron en campaña contra la tribu de los Banū al-Mușțaliq, ubicada en al-Muraysī', un oasis costero, hacia el sur, en dirección a La Meca, en las inmediaciones de Qudayd. ${ }^{35}$ Se trataba de una de esas expediciones de castigo que Muhammad lanzaba, encabezándolas él mismo, cuando, como en este caso, le llegaban noticias de que estaban conspirando en su contra. Pero quizás haya que apuntar en otra dirección: Qudayd era sede de un templo dedicado a la diosa Manāt, conectado con los qurayshíes, que obtendrían pingües beneficios de los rituales anuales que se celebraran allí. Ibn al-Kalbī (m. 819/821) sostiene que este santuario "fue levantado en la costa en las cercanías de al-Mushallal en Qudayd [...]. Todos los árabes solían venerarla y ofrecerle sacrificios". ${ }^{36}$ Era un templo que formaba parte del ḥadjij durante la diāhiliyya. ${ }^{37}$

Por tanto, no se trataría sólo de castigar a unos posibles rebeldes, sino de atacar uno de los negocios más lucrativos de quienes en esos momentos eran sus enemigos. Habría que leerla como una expedición para la obtención de botín y al mismo tiempo, calmar los ánimos entre los muhādjirūn (=emigrados) y los anșār (=ayudantes), después de los meses de reposo que habían pasado en Medina. Entra dentro de lo lógico el que se lanzaran a una expedición de este tipo después de las pérdidas, tanto humanas como materiales, que les había ocasionado el asedio y la batalla de Khandaq, unos meses antes.

¿Hubo realmente un complot orquestado por al-Ḥārith Abū Ḍirār o ésto sólo fue la excusa para caer sobre los Banū al-Mușțaliq en al-Muraysī'? Inmediatamente después de rechazar a los sitiadores en Medina, Muhammad decidió acabar con la tribu judía de los Banū Qurayẓa, a los que asedió durante veinticinco días y después exterminó porque jamás abandonarían su fe ancestral; $;{ }^{38}$ mientras hubiera un miembro de esta tribu, el Profeta nun-

34 Otras tradiciones lo adelantan un año, a sha'bān del 5 AH (ca. diciembre 626), Ibn Sa'd, Tabaqāt, ii. 1, p. 77.

35 Ibn Isḥāq, Sīrāt, p. 490; Tabarī, Ta'rīkh, viii, p. 51.

36 Ibn al-Kalbī, Așnām, p. 12 [FARIS, Nabih A. (1952), Hisham ibn al-Kalbi. The Book of Idols, Princeton University Press, Princeton].

37 Ibn al-Kalbī, Așnām, p. 13; CRONE, Patricia (1987), Meccan Trade and the Rise of Islam, Princeton University Press, Priceton, p. 191

38 Ibn Isḥāq, Sirrāt, p. 461-464; Tabarī, Ta'rīkh, viii, p. 27-41. 
ca hubiera podido consolidar su posición como líder en Medina y mucho menos haber conquistado La Meca. Pero obviamente, la tradición islámica no presenta este hecho como algo nacido de la voluntad de Muhammad, en tanto que líder político, sino que éste se mueve obedeciendo las órdenes de Gabriel, es decir, de Dios. ${ }^{39}$ Un comportamiento en línea con la teología del hērem judía, el exterminio de los enemigos de la fe. La expedición contra los Banū Lị̣yān es una continuación de la venganza que Muhammad quiso cobrarse sobre sus enemigos; eran la siguiente pieza que debía caer después de los Banū Qurayzạ. ${ }^{40}$ Pero la expedición contra los Dhū Qarad tuvo el carácter típico de las guerras tribales: era la respuesta del Profeta contra aquéllos que habían atacado sus rebaños de camellos. ${ }^{41}$

El resultado de la expedición contra los Muștaliq habla por sí solo: "mataron a muchos de ellos y entregaron a sus mujeres, hijos y propiedades como botín". ${ }^{42}$ La tradición que recogió al-Tabarī sobre el raid añade que este botín le fue entregado a Muhammad por Dios. ${ }^{43}$ Era el Profeta, como máxima autoridad de esa tribu que era la Umma, quien debía hacer los lotes a repartir entre quienes participaron en la expedición y lo hará con una cierta ecuanimidad. Eso es al menos lo que permite colegir una tradición transmitida por ' $\bar{A}$ ' isha al respecto del matrimonio de su esposo con Diūwayriyya al-Hārith Abū Dirār, recogida por lbn Sa d: "y tomó [Muhammad] el khums (=quinto) de ello y entonces lo dividió entre el pueblo. Dio a los jinetes dos partes y a los infantes dos partes", ${ }^{44}$ bien fueran esclavos, esclavas y otro tipo de bienes. En la parte de las Tabaqāt que dedica a la vida del Profeta, indica que un camello equivalía a diez cabras. ${ }^{45}$ Diūwayriyya entraba también entre lo repartido. Viuda de veinte años de Musafī' ibn Safwān, muerto en la batalla, ${ }^{46}$ la propia 'A' isha reconoce la animadversión que sintió por ella nada más verla; celos por cómo miraban los demás hombres a Diūwayriyya cautivados por su belleza. ${ }^{47}$

39 Ibn Sa'd, Tabaqāt, ii. 1, pp. 91-93.

40 Ibn Isḥāq, Sīrāt, p. 485-486; Ibn Sa d, Tabaqāt, ii. 1, pp. 97-99; Tabarī, Ta'rīkh, viii, p. 42-43.

41 Ibn Isḥāq, Sīrāt, p. 486-490; Tabarī, Ta'rīkh, viii, p. 43-51.

42 Ibn Isḥāq, Sìrāt, p. 490.

43 Tabarī, Ta'rīkh, viii, p. 51.

44 Ibn Sa'd, Tabaqāt, viii, p. 83.

45 Ibn Sa'd, Tabaqāt, ii. 1, p. 78.

46 Ibn Sa'd, Tabaqāt, viii, p. 83. Otras tradiciones no hacen mención a que antes hubiera estado casada: Ibn Isḥāq, Sīrāt, p. 493; Ṭabarī, Ta’rīkh, viii, p. 57.

47 Ibn Isḥāq, Sīrāt, p. 493; Ibn Sa d, Țabaqāt, viii, p. 83; Tabarī, Ta'rīkh, viii, p. 57. 
Tal vez haya que reconsiderar todo lo relacionado con la hija de Ḥārith Abū Dirār para darle una nueva interpretación a la acusación de adulterio contra ' $\bar{A}$ ' isha. Especialmente, en lo concerniente al comportamiento de Muhammad con el reparto del botín. He mencionado cómo la tradición islámica hace hincapié en la equidad con la que se procedió; una cuestión que debería servir para acallar cualquier crítica por cómo se condujo. Y aquí volvemos a la figura de Diūwayriyya. De acuerdo con todas las fuentes, la hija del líder de los Banū al-Mușțaliq había sido entregada como parte del lote que correspondía a Thābit ibn Qays ibn al-Shammās o a un primo suyo, ni la propia Diūwayriyya parecía estar muy segura de quién era su dueño. Pero lo importante es que ella acude a Muḥammad para que la liberase en atención a su estatus, en tanto que hija de un jefe tribal. Lejos de hacer valer los derechos de Thābit o su primo, el Profeta decidió quedarse con la mujer. Naturalmente, la liberó como paso previo a su boda con ella, que entró a formar parte de su harén. ${ }^{48}$ Pero el asunto no quedó ahí, y - siempre de acuerdo con la tradición islámica- el Profeta concedió la libertad a los prisioneros que ya habían sido repartidos entre los participantes de la expedición. ${ }^{49}$

Por más que se trate de presentarlo como un gesto de generosidad, lo que hizo Muhammad con Diūwayriyya fue una arbitrariedad, al quedarse con el botín de uno de sus hombres. Es lógico que levantara algunas ampollas entre los afectados y que éstos buscaran un modo de resarcirse. A ello habría que sumar la disputa por un manantial entre los muhādjirūn y los anșār, que se saldó con la derrota de estos últimos. ${ }^{50}$

Los responsables de la acusación de adulterio contra ' $\bar{A}$ ' isha fueron algunos miembros de la tribu de al-Khazradj, parte importante de los anșār. ${ }^{51}$ Ésta fue la otra guerra en la que 'A' isha tuvo que combatir y ver cómo antiguos aliados se mostraban tibios y dejaban de apoyarla. La acusación se perfila como una venganza política de los ayudantes contra los emigrados, celosos de los privilegios que éstos han ido acumulando, a costa de haber arrinconado a la oligarquía tradicional medinesa. ${ }^{52}$ Pero también se trató de un modo de expresar cierta oposición a las maneras que estaba adoptando el gobierno de Muhammad en Medina. Condenar a la hija de

48 Ibn Isḥāq, Sīrāt, p. 493; Ibn Sa 'd, Ṭabaqāt, ii. 1, pp. 78-79, VIII, p. 83; Ṭabarī, Ta'rïkh, viii, p. 57.

49 Ibn Sa'd, Tabaqāt, ii. 1, p. 79.

50 Ibn Sa'd, Tabaqāt, ii. 1, p. 79.

51 Ibn Isḥāq, Sïrāt, p. 495; Ṭabarī, Ta'rīkh, VIII, p. 61.

52 MONTGOMERY WATT, William (1956), Muhammad at Medina, Clarendon Press, Oxford. p. 186. 
Abū Bakr por adulterio hubiera comprometido seriamente su posición en la Umma; dejaría de ser uno de los hombres clave de la hierocracia construida por el Profeta en Medina y su puesto debería ser ocupado por otros, por qué no de las tribus de al-Khazradj.

De lo que no cabe duda alguna es de que 'A 'isha fue en todo momento un arma en manos de unos y otros por el poder. Quizás se pueda incluso plantear como hipótesis, como ya hizo Nabia Abbott, el que los munāfiqūn, miembros de los anșār buscaran, deslegitimando a Muhammad a través de la más joven de sus esposas, hacerse con el poder. ${ }^{53}$ Aunque creo que va más allá de las ambiciones personales de un personaje como 'Abd Allāh ibn Ubayy.

Habría que introducir algunos matices. La traducción más habitual que se ha dado para el término munāfiqūn es el de "hipócritas", pero el origen del término árabe habría que buscarlo en el etíope y el griego, ambos con el significado de "hereje", como aquel que se ha apartado del camino recto. ${ }^{54}$ 'Abd Allāh ibn Ubayy no era un mero arribista, sino que ya gozaba de una situación de preeminencia en la Medina previa a la llegada de Muhammad y los muhādjirūn. Según el relato de Ibn Ishāâ, fue a él a quien le consultan sobre la conveniencia o no de aceptar a los refugiados de La Meca, como el sheikh, el hombre fuerte de la ciudad, apoyado por un homólogo de los 'Aws, como propone P. Crone..$^{55}$ Según una tradición de la que se hace eco al-Balādhurī, ambas tribus estarían emparentadas, por vía materna, con los Banū Ghassān, ${ }^{56}$ lo que abre la posibilidad de que fueran cristianos monofisitas o al menos mostraran ciertas inclinaciones por esta Iglesia.

La irrupción en la escena medinesa de los musulmanes, dejó en suspenso la "entronización" de Ibn Ubayy como rey, como malik. De acuerdo con el relato de la Sirrāt Rasūl Allāh, al parecer todo estaba preparado para su coronación: "La gente de 'Abd Allāh ibn Ubayy había hecho una especie de diadema enjoyada para coronarlo y hacerlo su rey cuando Dios les envió a Su Mensajero" ${ }^{57}$ El hecho de que su pueblo lo abandonara para aceptar el islam y que por tanto su ascenso a la realeza quedara truncado, sería

\section{ABBOTT, Aishah, p. 29.}

54 JEFFERY, Arthur (2007), The Foreing Vocabulary of the Qur'ān. With a foreword by Gerhard Böwering and Jane Dammen McAulliffe, E. J. Brill, Leiden/Boston, [1 ${ }^{a}$ ed. 1932], p. 272.

55 Ibn Isḥāq, Sìrāt, pp. 205-206; CRONE, Meccan Trade, p. 217.

56 Balādhurī, Futūh, p. 33 [Hitti, Philip Khuri (trad.) (1916), The origins of the Islamic State, al-Baladhuri (K. Futūḥ al-Buldān), Columbia University Press, Nueva York].

57 Ibn Isḥāq, Sīrāt, p. 278. 
uno de los puntos de fricción con los recién llegados, a pesar de que, según reconoce el primer biógrafo del Profeta, Ibn Ubayy también aceptara la nueva religión, aunque por motivos de pragmatismo político. ${ }^{58} \mathrm{El}$ hecho de que se use el término munāfiqūn y no el de kuffār (sing. kāfir) indicaría que no se trata de una diferencia religiosa, de la no aceptación del islam, sino de oponerse a Muhammad como líder político. De la raíz k-f-r, significó en un primer momento "cubrir" u "ocultar", pero por influencia del arameo y el hebreo, es decir, del sistema de valores del judaísmo, la palabra se cargó de un contenido religioso, moral, identificando a los incrédulos, a los que niegan la existencia de Dios. ${ }^{59}$ No era el caso de los medineses partidarios de Ibn Ubayy, que tal vez compartieran buena parte de los postulados religiosos del Profeta, pero no su afán por acabar con la independencia de Medina. A fin de cuentas, se trataría de conservar los privilegios de la antigua aristocracia por medio de la deposición de Muhammad, atacando su moralidad a través de la de 'A' isha.

Todo este caso de la acusación de adulterio, lo que la tradición islámica llama el 'ifk, "el asunto de la mentira", tiene ciertos toques novelescos por el modo en el que se produjo y se desarrolló. Durante el regreso a Medina tras la expedición contra los Banū al-Mușțaliq, 'A' isha marchaba sobre un palanquín a lomos de un camello y quedó rezagada. Según cuenta ella misma - de acuerdo con las tradiciones recogidas que la tienen como la autoridad principal del isnād (=cadena de transmisión)-, cuando las mujeres del Profeta acompañaban al ejército musulmán, estaban sujetas a las mismas privaciones, 60 pero en torno a ella iba una serie de hombres encargados de ensillar el camello y guiarlo durante la marcha, agarrado por las bridas. No obstante, lo más interesante y lo que dará en parte pie a todo el affaire, es que ' $\bar{A}$ 'isha viajaba completamente oculta, protegida por el hidjāb que envolvía el palanquín. Por eso, los hombres a su servicio creyeron que estaba dentro cuando lo colocaron de nuevo sobre el lomo del animal para reanudar el camino a Medina. Pero la chica no estaba. De acuerdo con su propio testimonio, había tenido que ir a aliviarse cuando se dio la orden de proseguir la marcha. Y aquí vuelve a ponerse de manifiesto la nueva moral que se había impuesto en lo concerniente al comportamiento de las mujeres en la esfera pública. Obediente a las directrices

58 Ibn Isḥāq, Sīrāt, p. 279.

59 MONFERRER, Juan Pedro (2006), "«¿̨ué les queda a las putas para jactarse?». Una invectiva paleoislámica de subtemática proto-martirial", Al-Andalus Magreb:Estudios árabes e islámicos, vol. 13, pp. 163-181, espec. 171; y JEFFERY, Foreing Vocabulary, p. 250.

60 Ibn Isḥāq, Sìrāt, p. 494; Tabarī, Ta'rīkh, viii, p. 58. 
recientemente impuestas por Muḥammad, 'A' isha improvisó un hidjāb con su propia ropa para resguardarse de las miradas de los musulmanes que acudieran en su búsqueda. ${ }^{61}$

Ante todo, había que preservar la integridad moral de la nueva mujer musulmana. Sin embargo, esta actitud no evitó que se acusara a 'A' isha de adulterio. Hay dos episodios que jugaron en su contra. En primer lugar, la desaparición del collar de cuentas que su marido le trajera de Zafār y según ella misma confiesa, perdió sin darse cuenta la mañana misma en que quedó rezagada. ${ }^{62}$ Su ausencia sería una de las pruebas esgrimidas por los al-Khazradi para armar todo el revuelo. No obstante sería el comportamiento poco acorde con esa misma nueva moral que demostró Șafwān ibn al-Mu atțal al-Sulamī, de quien 'A' isha cuenta que también se había quedado rezagado del resto del ejército y que pasó por delante de donde ella estaba y levantó el hidjāb con el que se cubría. Reconociéndola como la esposa del Profeta, le preguntó por qué estaba allí pero ella no le respondió. Sería Șafwān quien la condujera de regreso a Medina, pero marchando detrás del camello, ${ }^{63}$ quizás como un gesto de respeto tanto por la joven a la que acompañaba como por el hombre con el que estaba casada.

Los días que siguieron a su regreso fueron extraños para ella. Es llamativa la queja que expresa: "Cuando estaba enferma, él [Muhammad] solía mostrarme su compasión y bondad, pero en esta enfermedad no hizo nada y lo eché de menos". ${ }^{64}$ Muestra la soledad que sintió y lo delicado de la situación en que se encontraba, no sólo ella, sino su propia familia, su padre y su esposo. Pero sobre todo es una prueba de que se trataba de una adolescente de trece años envuelta en los juegos de la política tribal. 'A' isha no sabe nada de qué está pasando hasta que no se lo dice una de las instigadoras del bulo: Misțaḥ bint Djaḥsh, la hermana de Zaynab, y esposa del Profeta, pertenecientes al clan de 'Awf $f^{65}$ - una división de los al-Khazradi-. De hecho, ella misma estaba emparentada con Misțaḥ: su madre era prima de Abū Bakr, ${ }^{66}$ dándole al asunto del 'ifk un cierto aroma a rencilla familiar. Sin embargo, quizás lo más destacado sea la actitud

61 Ibn Isḥāq, Sirrāt, p. 494; Tabarī, Ta'rīkh, viii, p. 59.

62 Ibn Isḥāq, Sïrāt, p. 494; Ṭabarī, Ta'rīkh, viii, p. 59.

63 Ibn Isḥāq, Sīrāt, p. 494; Ṭabarī, Ta'rīkh, viii, p. 59.

64 lbn Isḥāq, Sīrāt, p. 495.

65 bn Isḥāq, Sīrāt, p. 495.

66 Ibn Isḥāq, Sìrāt, p. 495; Ṭabarī, Ta'rīkh, viii, p. 60. 
que demostraron los hombres en esa reunión convocada por Muhammad para tratar de esclarecer la situación y dilucidar qué hacer con 'A 'isha en caso de ser hallada culpable.

Que era una cuestión tribal queda fuera de toda duda. Proteger el honor de la joven esposa del Profeta equivalía para muchos a proteger el suyo propio. Pero en este caso, va mucho más allá, ya que se trataría de hacer valer la importancia de un grupo extraño, los muhādjirūn, incardinados en un cuerpo extraño, como era la sociedad de Medina. La acusación de adulterio lanzada contra ' $\bar{A}$ 'isha podría haberse convertido perfectamente en un casus belli que hubiera dinamitado la unión con los anșār, envueltos ambos grupos en una guerra civil. Es al menos lo que se desprende de las palabras de uno de los convocados a esa reunión: "Si son [los difamadores] de los 'Aws, nos deshacemos de ellos; si son de los al-Khazradj, danos tus órdenes porque deberían tener las cabezas cortadas". ${ }^{67}$ Deja poco lugar a dudas acerca de la animadversión que sentían por ambas tribus, e iría más allá de un conflicto con los munāfiqūn. No obstante, en esa reunión había otros que estaban dispuestos a defender los derechos de los anșār, evitando el derramamiento de sangre quizás por sus propios intereses, marcados por su posición dentro de la Umma y sus relaciones con los medineses. La prudencia de algunos hombres "piadosos" habría que leerla como el reconocimiento de la debilidad de los musulmanes. No olvidaban que eran un grupo encastrado en otro mayor y que no eran sino huéspedes. Empezar una guerra contra los al-Khazradj hubiera supuesto la aniquilación.

No obstante, sobre lo que me interesa llamar la atención es acerca de la postura adoptada por 'Alī ibn Abī Ṭālib en el transcurso de la reunión/juicio que se estaba siguiendo. $Y$ me resulta importante porque en buena medida marcó lo que sucederá casi treinta años más tarde. El juicio del primo del Profeta muestra a 'A' isha como una pieza reemplazable: "Las mujeres son abundantes y fácilmente puedes cambiar una por otra". ${ }^{68}$ Una posición muy inestable para la que sería conocida como umm al-mu'minin (=madre de los creyentes), como todas las esposas de Muhammad, además por revelación divina: "Las esposas de aquél [el Profeta], son las madres de éstos [los musulmanes]". ${ }^{69}$ Ese modo de no implicarse en su defensa, máxime cuando pertenecían a la misma familia, tuvo que ser un golpe para 'A' isha, quien vio cómo uno de los principales hombres de la comunidad le daba la espalda.

67 Ibn Isḥāq, Sīrāt, p. 495.

68 Ibn Isḥāq, Sìrāt, p. 496; Ṭabarī, Ta'rïkh, viii, p. 62.

69 Corán, 33, 6. 
Fue 'Alī quien recomendó a Muhammad que interrogara a Burayra, la esclava que iba con su mujer, para conocer la verdad y cuyo testimonio resultaría definitivo para exculpar a 'A' isha. La única falta de la que podía acusar a su señora era que no vigilaba la masa, que se quedaba dormida y la oveja se la comía. ${ }^{70}$ Una nota de color costumbrista que viene a relajar la tensión existente y a dar un argumento para exonerar a la joven de toda culpa. Es una escena que gira en torno a la cotidianidad de las mujeres árabes - en este caso da igual que sean o no musulmanas-, cuyo espacio y funciones es el doméstico y ligado a la reproducción y sostenimiento del grupo. Lo privado-femenino versus lo público-masculino. Toda aquella mujer que se atrevía a penetrar en la esfera pública era considerada una prostituta, a la que los hombres cuestionaban su integridad y quedaba a merced de cualquier abuso. ${ }^{71}$

Antes mencionaba el uso de la poesía como arma política. En el caso de la acusación de adulterio contra 'Ā'isha, además se usó como arma de guerra entre los dos bandos enfrentados. Tuvo una participación destacada quien sería uno de los principales poetas del período paleo-islámico, primero como opositor y después, a consecuencia de este episodio, como firme partidario de Muhammad: Ḥassān ibn Thābit, miembro de los al-Khazradj. Él fue uno de los más implicados en la campaña de desprestigio emprendida contra los musulmanes a través de la figura de la más joven de las esposas de su profeta-guerrero y como tal merecedor del castigo que se le impuso, los ochenta latigazos estipulados en el Corán contra aquéllos que levantaban falsas acusaciones. ${ }^{72}$ Es un personaje que ejerció como nexo de unión entre los árabes iranizados de los Banū Lakhm y la península arábiga, ${ }^{73}$ introduciendo muchos de los usos y costumbres cortesanos en La Meca y Medina, incidiendo en una imagen mucho más "civilizada" de la Arabia pre-islámica que la que se ha venido dando.

Los versos que recoge Ibn Isḥāq prueban la animadversión de Ḥassān ibn Thābit contra los musulmanes, a los que llamaba "inmigrantes vagabundos" y acusaba de violar las leyes vigentes: no pagaban por la sangre derramada. ${ }^{74}$ Por desgracia, no se han conservado ninguna de las invec-

70 Ibn Isḥāq, Sìrāt, p. 496; Ṭabarī, Ta'rīkh, viii, p. 62.

71 BARLAS, "Believing women", p. 56.

72 Ibn Isḥāq, Sīrāt, p. 497; Ṭabarī, Ta'rīkh, viii, p. 63. Vid. Corán, 24, 4.

73 STETKEVYCH, Suzanne Pinckney (2002), The Poetics of Islamic Legitimacy. Mith, Gender and Ceremony in the Classical Arabic Ode, Indiana University Press, Bloomington/Indianapolis, pp. 44-47.

74 Ibn Isḥāq, Sīrāt, p. 498. 
tivas que lanzara contra ' $\bar{A}$ 'isha. Con todas las reservas, no sería muy descabellado que estuvieran en línea con la que compuso la musulmana Hind bint Uthāthā contra la mecana Hind bint 'Utba, en la que la acusa de haber cometido adulterio - ella también - con Waḥshī, el esclavo negro:

entregaste a Waḥshī lo que [tu] pecho sentía.

Waḥshī ha rasgado el velo del cortinaje, después de ella, ¿̇qué les queda a las putas para jactarse? ${ }^{75}$

Esta hipótesis vendría probada por los versos que compuso después de que se ejecutara la sentencia:

Casta, manteniéndose en su casa, por encima de toda sospecha, nunca pienso en vilipendiar a mujeres inocentes; una mujer noble del clan de Lu'ayy ibn Ghālib, buscadores de honor cuya gloria nunca se desvanece. ${ }^{76}$

Cualquier insulto contra la familia y el clan quedaba así reparado, aludiendo a la honestidad de sus mujeres e incidiendo en algo que ya he mencionado: el espacio doméstico, privado, como el único reservado para ellas. Era en él donde podían sentirse a salvo de cualquier peligro; pero también los hombres, que no se veían interpelados por las mujeres en la esfera pública. El del hogar es asimismo un espacio donde ellos pueden controlar más fácilmente la sexualidad femenina.

El episodio de la exoneración de 'A' isha y el castigo de los maledicentes juega con esos aspectos "caballerescos" que la cultura de la aristocracia árabe pre y paleo-islámica habrían tomado de los persas sasánidas. En este caso, el protagonista es alguien a quien ya se ha mencionado: Șafwān ibn al-Mu aț̣al. Él había dado pie, con su actuación, a que comenzaran los ataques contra la mujer de Muhammad y la tradición islámica lo presenta como el responsable de prender a Ḥassān ibn Thābit para llevarlo al suplicio. ${ }^{77}$ Era el modo de redimir su comportamiento poco respetuoso. No obstante, es igualmente ilustrativo de la tensión existente entre muhādjirūn y

75 MONFERRER, "«¿Qué les queda...?"», pp. 177-181.

76 Ibn Isḥāq, Sīrāt, p. 499.

77 Ibn Isḥāq, Sirrāt, p. 498; Tabarī, Ta'rīkh, viii, pp. 64-65. 
anșār el hecho de que Șafwān acudiera a arrestar a Ḥassān con la espada en la mano.

Muy posiblemente, fueran conscientes de que las penas impuestas desatarían represalias contra los musulmanes. Porque no sólo fue castigado el poeta, sino también dos mujeres, la ya mencionada Misțah y Ḥamna. ${ }^{78}$ Vuelvo a plantear la hipótesis de que ellas hubieran compuesto algunos versos satíricos acerca de la honestidad de 'A' isha y no sólo haberse limitado a propagar rumores por los mentideros de Medina. Pero el hecho de que el verdadero artífice e instigador de todo, Ibn Ubayy, no hubiera sido castigado pone de manifiesto que, a pesar de que Muhammad y los muhādjirūn tuvieran el monopolio de la violencia y el poder en la ciudad, la aristocracia tradicional y sus redes clientelares seguían siendo un elemento a tener en cuenta, sin los cuales Medina difícilmente podría ser gobernada.

\section{Viuda ¿SEÑora de La GUerRa?}

Cuando murió Muhammad, 'A' isha tenía dieciocho años, ${ }^{79}$ marcando un punto de inflexión en su propia vida. Su estatus como viuda, la situaba en un plano similar al de Khadīdja. Haber sido la esposa del Profeta e hija de un califa, le daba una consideración especial en la sociedad islámica. Ella, al igual que el resto de las viudas de Muhammad tenían prohibido volver a casarse. ${ }^{80}$ La tradición islámica alude a que nadie pudo acceder a la herencia dejada por el Profeta, lo que no quiere decir que ella quedara en la indigencia. Cuando cayó enfermo su padre, éste hizo a 'A' 'isha depositaria de pequeños fondos públicos y propiedades, convirtiéndola en la depositaria del legado de sus hermanos y hermanas. ${ }^{81} \mathrm{~A}$ esto habría que añadir la parte que le correspondía de las riquezas que afluían al Hiidjāz procedentes de las provincias conquistadas durante el califato de 'Umar ibn al-Khațāâ. Ibn Sa'd cuenta, por ejemplo, cómo el califa dio a las viudas de Muhammad diez mil dirhams y añadió dos mil más a la parte que le correspondía a 'A' isha por ser la esposa favorita. ${ }^{82}$

78 Ibn Isḥāq, Sīrāt, p. 497; Tabarī, Ta'rīkh, viii, pp. 63.

79 Ibn Sa'd, Tabaqāt, viii, p. 44.

80 AHMED, Leila (1992), Women and Gender in Islam. Historical Roots of a Modern Debate, Yale University Press, New Haven/Londres, pp. 49 y 74.

81 ABBOTT, Aishah, p. 85; y AHMED, Women, p. 74.

82 Ibn Sa'd, Ṭabaqāt, viii, p. 48; Ṭabarī, Ta'rīkh, xii, p. 202 [FRIEDMAN, Yohanan (1992), The History of al-Tabarī. Vol 12: The Battle of al-Qãdisiyyah and the Conquest of Syria and Palestine, SUNY, Nueva York]. 
Pero no es la única mención que hace este tradicionista a la riqueza que pudo haber amasado esta mujer a lo largo de los años. Su patrimonio procedía de los rendimientos de las herencias recibidas, ${ }^{83}$ aunque lejos de ser una rentista como la presenta la tradición islámica, no se debe descartar que ella misma se implicara, como Khadīdja, en la gestión de sus bienes. Es posible que una parte de esos fondos que le legó su padre estuvieran relacionados con la explotación de las minas de oro de la península arábiga, a los que habría que sumar los beneficios obtenidos por el comercio caravanero con Siria ${ }^{84}$ ¿̇Habría cambiado ella también el comercio por el pillaje? Quizás así se expliquen los cien mil dirhams que lbn al-Zubayr le hizo llegar y 'A' isha, según la tradición, hizo repartir entre el pueblo. ${ }^{85}$ Hace también Ibn Sa'd alusión a setenta mil dirhams que donó en calidad de șadaqa (=limosna), ${ }^{86}$ y lo determinante no es sólo la cantidad sino el objetivo de ese dinero. Se podría aventurar la idea de que pudiera servir para mantener su propia red clientelar que ' $\bar{A}$ ' isha se encargaría de movilizar cuando llegara el momento.

He planteado la hipótesis de que ' $\bar{A}$ ' isha se hubiera beneficiado de los réditos de la conquista, a través del botín traído a Medina por hombres a su servicio. Sin embargo, podría plantearse el que se implicara personalmente; que estuviera in situ en algunas campañas y más en concreto, en las que condujeron a la conquista de la Persia sasánida. No hay ninguna fuente que permita establecer su presencia en la batalla de al-Qādisiyya (636); ${ }^{87}$ no se ha conservado ningún relato que diga que efectivamente estuvo al lado de los árabes que derrotaron a Rustam. Pero quizás se pueda sostener sobre la base de los isnāds que cita al-Tabarī para este acontecimiento y que la tienen a ella como la principal autoridad de lo que cuenta. ${ }^{88}$ Esto nos permitiría aventurar que tal vez 'A' isha pudo ser testigo directo de la batalla. Quizás la viera desde el palanquín de su camello, oculta por el

83 Ibn Sa'd, Țabaqāt, viii, p. 47; AHMED, Women, p. 80.

84 CRONE, Meccan Trade, pp. 94 y 116.

85 Ibn Sa'd, Tabaqāt, viii, p. 47.

86 Ibn Sa'd, Tabaqāt, viii, p. 47.

87 McGRAW DONNER, Fred (1981), The Early Islamic Conquest, Princeton University Press, Princeton, pp. 203-210; y POURSHARIATI, Parvaneh (2008), Decline and Fall of the Sasanian Empire. The Sasanian-Parthian Confederacy and the Arab Conquest of Iran, Tauris, Londres/ Nueva York, pp. 232-236.

88 Ṭabarī, Ta'rīkh, xii, p. 46 y xiii, p. 10 [JUYNBOLL, Gautier H. A. (1989), The History of al-Tabarī. Vol 13: The Conquest of Iraq, Southwestern Persian and Egypt, SUNY, Nueva York]. 
hidjāb, a salvo de miradas indiscretas. Sabemos por Mas 'ūdī y otros tradicionistas, que Țalḥa ibn 'Ubayd Allāh y Zubayr ibn al-'Awwām estaban con el ejército que combatió en la batalla del Puente $(634)^{89}$ y no sería descartable que la viuda de Muhammad acompañara a quienes eran sus aliados más cercanos, en especial a Țalha. De hecho, sabemos de la presencia de un número considerable de mujeres de las tribus árabes que acabaron por casarse con los veteranos asentados en la zona tras la batalla, aunque pertenecientes a otros clanes. ${ }^{90}$

Entre finales del año 23 y comienzos del $24 \mathrm{AH}$ (ca. 644), en la Umma se produjo un cambio de tendencia. El asesinato del califa 'Umar ibn alKhatțāâ ${ }^{91}$ iba a marcar el fin de un califato cuya sucesión se había mantenido fuera de las lógicas tribales, por más que 'Umar hubiera sido suegro de Muhammad. Se pusieron de manifiesto, una vez más, las tensiones existentes entre los diferentes grupos que conformaban el primer Estado islámico, acrecentadas por el éxito fulgurante de las campañas de conquista. Pero nos equivocaríamos si pensáramos que las luchas por el poder, por establecer quién ostentaría el título de califa, era algo que ocupaba a toda la comunidad. Antes bien, ésto se consideraba un asunto local, una disputa interna que afectaba a las elites de Medina especialmente. ${ }^{92}$

La elección del sucesor de 'Umar no competía a toda la Umma, sino que debía decidirse entre un grupo aristocrático. Es lo que en la tradición islámica ha pasado con el nombre de shūrā, un collegium formado en este caso por seis hombres procedentes de la nueva elite. Entre ellos estaban ' $U$ thmān ibn 'Affān y 'Alī ibn Abī Ṭālib, pero también Ṭalḥa ibn 'Ubayd Allāh y Zubayr ibn al-'Awwām, junto con otros dos miembros más de esa casta arabo-musulmana que se había hecho con el poder en el Ḥidjāz. ${ }^{93}$ Sin embargo, esta shūrā no podría adoptar ninguna resolución sin que antes ' $\bar{A}$ 'isha

89 Ṭabarī, Ta'rīkh, xii, pp. 5-6; Mas'ūdī, Murūdj, iv, § LXXVI, p. 201 [BARBIER DE MEYNAR, Charles y DE COURTEILLE, Pavet (1965), Les prairies d'or. Revisada y corregida por Charles Pellat. 4 vols., Societé Asiatique, París]. Sobre la batalla, vid. McGRAW DONNER, Early Islamic, pp. 197-200; y POURSHARIATI, Decline and Fall, pp. 214-219.

90 MORONY, Michael (1984), Iraq after de Muslim Conquest, Princeton University Press, Princeton, p. 237.

91 Mas 'ūdī, Murūdj, iv, § LXXVI, p. 226-228; Tabarī, Ta'rïkh, xiv, pp. 89-93 SMITH, Gerald Rex. (1994), The History of al-Tabarī. Vol 14: The Conquest of Iran, SUNY, Nueva York].

92 CAETANI, Leone (1914), Annali dell'Islam, vol. 7, Ulrico Hoepli, Milán, § 2.

93 Ṭabarī, Ta'rïkh, xiv, pp. 145-146. 
diera su visto bueno. ${ }^{94} \dot{2}$ Esta consideración se debía sólo a que había sido la esposa favorita de Muhammad? Tal vez haya que pensar que respondía a un reconocimiento implícito a su papel en el desarrollo del Estado paleo-islámico. Hemos visto cómo había amasado una considerable fortuna y que con toda probabilidad se viera envuelta en parte de la conquista de la Persia sasánida. 'A' isha se perfila como un elemento político a tener en cuenta en lo que a la estabilidad del califato se refiere. Obviamente, no la iban a sentar en pie de igualdad con el resto de los prohombres musulmanes, pero su aquiescencia o negativa suponía que sus clientes se movieran en un sentido u otro. Jugando, eso sí, en un campo eminentemente local, por más que la tradición islámica posterior le dé una dimensión panárabe. Hacía valer su condición de umm al-mu'mininn, de madre de los creyentes. Este título no sería algo meramente simbólico..$^{95} \mathrm{He}$ aludido antes a que en el Corán se les daba este epíteto a todas las esposas de Muhammad, pero no es menos cierto que en otra tradición, ésta recogida por Ibn Sa'd y atribuida a Ibn 'Abbās, se le da a ella este título en exclusiva. ${ }^{96}$ En un período en el que religión y política se funden y confunden, el título tendría un aspecto más práctico. Hay que recordar que, en estos momentos, no se usaba el término califa (ár. khalîfa) para referirse al máximo dirigente islámico, sino el de amīr al-mu'minīn (=caudillo de los creyentes), lo que nos llevaría, como hipótesis, a establecer una cierta concordancia entre ambos. Obviamente, no pretendo equipararlos, pero sí señalar que entrarían dentro de una misma lógica.

La autoridad de 'A' isha como umm al-mu'minin vendría marcada por un aspecto que le otorgan las tradiciones referidas a ella, la de ejercer como intermediaria entre el pueblo, los creyentes, y sus dirigentes; una autoridad de tipo no menos carismática que la ostentada por los rashidūn. Por tanto, sería este estatus politico-religioso lo que le llevaría a intervenir en la designación de los califas o lo que le legitimaría para ponerse al frente de un ejército, bien fuera durante la conquista de Persia o en la guerra civil para destronar a 'Alī. Es muy llamativo que, a pesar de ostentar este título, ella jamás fuera madre y no por ello viera menguada su influencia. ${ }^{97}$

La shūrā, el collegium elector, se había decantado finalmente por el más débil de los candidatos, por 'Uthmān ibn 'Affān; aquél que, en palabras de

94 Tabarī, Ta'rïkh, xiv, p. 145.

95 SPELLBERG, "Political Action", p. 52.

96 Ibn Sa'd, Tabaqāt, viii, p. 53.

97 BARLAS, "Believing women", p. 179. 
Mas 'ūdī, inauguró un reinado que no tenía nada que ver con la austeridad y rigorismo del anterior. ${ }^{98}$ Los hombres fuertes de Medina, como Ṭalha o el propio 'Alī, estarían esperando su oportunidad para suceder al califa en cuanto éste cayera. La "mujer fuerte", 'A' isha, en un primer momento tampoco tuvo inconveniente en que el califato recayera en él. A pesar de esto, el nuevo califa adoptó medidas en su contra, como cabeza visible de la nueva casta islámica, reduciéndole la pensión que percibía hasta situarla al mismo nivel que el resto de las viudas del Profeta. ${ }^{99}$ Era una medida que contrasta con el dispendio con el que solía actuar 'Uthmān. ${ }^{100} \mathrm{Tal}$ vez haya que verlo como un ataque directo contra la que era la principal figura femenina de Medina, sacándola de la esfera pública.

'A' isha era la única de las viudas de Muhammad que tenía un papel activo. Por eso, equipararla al resto era recordarle cuál debía ser su posición en la sociedad islámica. Tal vez por esta razón, quizás no se tratase sólo de reducirle la asignación, sino que se vetara a ' $\bar{A}$ ' isha la posibilidad de seguir gestionando los bienes que su padre le había legado y que además hubiera algún tipo de confiscación. No obstante, esto sólo son especulaciones. Hipótesis a un lado, lo cierto es que socavar su poder económico equivalía a dejarla sin opciones para actuar en la esfera pública. Formaba parte de esa política puesta en marcha por el nuevo califa, tendente a favorecer a la gente de su propio clan en detrimento de quienes habían ostentado el poder dentro de la Umma. Será ahora cuando 'Á' isha intervenga de manera más clara en la política del califato. La razón que explicaría este cambio, sería que hasta el gobierno de 'Uthmān no había visto amenazado su estatus. Esta reacción entraría dentro de la lógica de quien ha logrado alcanzar y afianzar una posición social, política y económica, a fuerza de verse cuestionada por un sector de la comunidad islámica, que la puso en entredicho. Madelung sostiene que decidió socavar las bases del califato porque pensaba que 'Alī estaba descartado para suceder a 'Uthmān; que, si el primo y yerno del Profeta daba el primer paso para alzarse en armas contra el califa, ella sería la principal perjudicada. ${ }^{101}$

$Y$ en este punto cabe la duda de si 'A' isha estaba dispuesta a tomar el poder para sí misma, haciéndose nombrar califa, o si, por el contrario, cedería ese honor a quien la acompañó durante toda su trayectoria, Țalha

98 Mas'ūdī, Murūdi, iv, § LXXVII, p. 255.

99 ABBOTT, Aishah, p. 105.

100 Mas'ūdī, Murūdj, iv, § LXXVII, p.252.

101 MADELUNG, Succession, p. 107. 
ibn 'Ubayd Allāh. De hecho, no se puede descartar la primera opción. En estos años de profundas transformaciones, hubo cabida para el gobierno de mujeres, como fue el caso de Būrāndukht y su hermana Azarmīdukht, que rigieron la Persia sasánida entre 630-632, en medio de una enorme inestabilidad política, interna - guerra civil-y externa - conquista islámica-. ${ }^{102}$ Existiendo este antecedente, es plausible que ella quisiera coronarse; contaba con los apoyos necesarios para ello. La reacción de los tradicionistas musulmanes en ambos casos, el de 'A' isha y Būrāndukht, es muy similar, avisando de los peligros que entrañaba cualquier gobierno femenino, entendido como sinónimo de inestabilidad y caos. ${ }^{103}$ Para el caso persa, Abū Bakra recuerda que al saber Muhammad que en el trono de Ctesifonte se sentaba una mujer, se lamentó por la suerte de la dinastía sasánida, condenada a desaparecer. ${ }^{104}$

\section{Conclusiones}

La guerra ha sido entendida como un mundo netamente masculino del que en principio estarían excluidas las mujeres. No obstante, ellas serán testigos y víctimas del conflicto, tomando a veces un papel protagonista que ha quedado ensombrecido, visto como una transgresión del orden social vigente, en nuestro caso, en el islam. El de 'A' isha es un ejemplo paradigmático de esa voluntad de romper ciertos clichés que tienen que ver con el confinamiento de la mujer en el espacio privado del hogar y sin ninguna implicación en la vida pública.

Ya desde ese primer contacto con la violencia de una batalla, en la lejanía y a resguardo de los muros de una fortificación, quiere inmiscuirse en el devenir de los acontecimientos. En la batalla de al-Khandaq vemos cómo la guerra deja en suspenso ciertas convenciones en lo referente a la separación del espacio según los sexos. Así pues, un hombre, un guerrero que antes que nada es también hijo de su madre, irrumpe en las habitaciones de las mujeres. Bien es cierto, que ésto se produce cuando aún Muhammad no había decretado que un velo debía mantener ocultas a las mujeres. Pero también se da a la inversa: cuando 'A' isha irrumpe en una esfera propia de los varones, esa guerra de la que ella debía mantenerse alejada. Era la curiosidad lo que la llevó hasta donde estaban los guerreros árabes que regresaban y marchaban a la batalla, donde la joven esposa de un

102 CHRISTENSEN, Iran, p. 498; y POURSHARIATI, Decline and Fall, pp. 207-214.

103 SPELLBERG, "Political Action", p. 51.

104 MERNISSI, Harén, p. 61. 
profeta-guerrero podía ser testigo de las debilidades de los hombres. La reprimenda de 'Umar no tenía que ver sólo con su seguridad, sino también con el hecho de haber entrado en un mundo que no le correspondía. Era la primera bid'a que llevaba a cabo.

Lo que ve 'A' isha, según narran las tradiciones islámicas, es una guerra de corte caballeresco; la usual en un mundo regido por las costumbres militares que habían impuesto los dos grandes imperios del momento, la Persia sasánida y el Imperio romano de Oriente. Y sobre todo ésta primera, cuya influencia en la región del Hiidjāz está fuera de toda duda: al norte se hallaba la Siria-Palestina controlada por los sasánidas y al sur, el Yemen también persa. Así, entra dentro de lo esperable que los campeones musulmán y pagano parezcan más cercanos al prototipo de guerrero aristocrático sasánida que al ideal del guerrero islámico. La propia estrategia seguida por Muhammad para detener a sus enemigos, está indicando no sólo que existía una organización militar entre las confederaciones tribales árabes, sino que éstas estaban imbuidas por las modas importadas de fuera de las fronteras de la península arábiga.

Pero la guerra se libra por otros medios y tiene al cuerpo femenino como arma y al mismo tiempo como campo de batalla. Y aquí tiene un papel destacado la concepción del honor en las sociedades patriarcales, que reside en la honra de sus mujeres. El peligro que entrañaba para la oposición de una parte importante de la oligarquía de Medina enfrentarse directamente a Muhammad, hizo que atacaran a 'A' isha como el único modo de deshacerse del profeta-guerrero que estaba imponiendo un orden de cosas con el que no estaban de acuerdo. En este sentido, la poesía satírica usada como un medio de propaganda fue fundamental. No era la primera vez que se empleaban los versos compuestos por los y las poetas tribales con el fin de denigrar al rival. La acusación de adulterio contra 'A' isha nació en el contexto de una de las expediciones de castigo contra los enemigos de los musulmanes y las disensiones que pudieron surgir por el modo en que se repartió un botín, compuesto fundamentalmente por las mujeres de la tribu vencida. El "asunto de la mentira" sentó las bases de la enemistad de la esposa de Muhammad con 'Alī ibn Abī Țālib. Su posición en el juicio, favorable al divorcio, vendría marcada por el deseo de 'Alī de no enemistarse con los medineses que habían propalado el rumor. Sabía que la posición de los emigrados mecanos era precaria y una guerra civil en Medina podía acabar con la recién nacida comunidad islámica.

Sin embargo, habrá que esperar a la viudedad de 'A' isha para verla actuar de forma autónoma, como ya lo hicieran otras viudas, como Khadīdja. Las fuentes no son claras, por lo que tenemos que leer entre líneas y plantear una serie de hipótesis que deberán ser contrastadas con nuevos relatos. 
Una de ellas es su posible participación en la conquista de Persia, partiendo de las citas que los tradicionistas hacen situándola como la principal autoridad de la que beben. Esto la convertiría en una suerte de testigo presencial de los hechos y me permite especular con la posibilidad de que ' $\bar{A}$ ' $\mathrm{i}$ sha fuera una "señora de la guerra", algo nada raro en el contexto oriental del siglo VII. La guerra, los botines obtenidos, se habrían convertido en una fuente de riqueza nada desdeñable, tanto para ella como para el resto de la sociedad árabe, que vio cómo durante los años de la conquista afluían a Medina, la capital del califato paleo-islámico, grandes cantidades de oro, plata y todo tipo de productos agrícolas y manufacturados.

Muy posiblemente, ese carácter de "señora de la guerra" unido al hecho de ser la viuda de Muhammad, le confirió una autoridad especial que le permitió intervenir en la vida política durante el gobierno de los dos últimos califas rashidūn. Llegados a este punto, la incógnita es si lo hizo movida por el deseo de poder personal o por un prurito religioso al ver que se estaban alejando de los preceptos originales del islam. Por mi parte, introduzco una tercera posibilidad: que lo hiciera en defensa de los intereses del grupo al que pertenecía, el de la nueva aristocracia islámica. 


\title{
LA PARTICIPACIÓN FEMENINA EN LOS SITIOS DE ZARAGOZA. LA PERCEPCIÓN DEL MANDO MILITAR Y EL INTERÉS DEL PODER POLÍTICO
}

\author{
FEMALE PARTICIPATION IN THE SIEGES OF \\ ZARAGOZA. THE PERCEPTION OF THE MILITARY \\ COMMAND AND THE INTEREST OF POLITICAL \\ POWER
}

Francisco Ramiro Moya

Universidad de Zaragoza

\section{RESUMEN}

Este artículo estudia el papel desarrollado por las mujeres combatientes en los Sitios de Zaragoza durante la Guerra de la Independencia; el tipo de acciones en las que tomaron parte, sus oportunidades para salir del anonimato y su sufrimiento durante y después de la contienda. Además, atiende a los diferentes intereses de la movilización femenina durante la batalla y a la posterior imagen de las heroínas zaragozanas, indagando acerca de las motivaciones de las propias protagonistas, de los mandos militares de la plaza y del poder político que, tras la guerra, afrontó la labor de construcción del estado liberal. Palabras clave: Guerra de la Independencia, Sitios de Zaragoza, mujeres combatientes, historia de las mujeres.

\begin{abstract}
This article studies women's role in the Sieges of Zaragoza during the Peninsular War; the kind of actions in which they participated, their opportunities to lose their anonymity, and their suffering during and after the war. Moreover, it deals with the different interests of the female mobilization during the battle and the subsequent image of Zaragoza's heroines, examining the motivation of the protagonists, the military commanders and the politicians who, after the war, had to construct the liberal state.
\end{abstract}

Keywords: Peninsular War, Sieges of Zaragoza, Women Fighters, Women History. 


\section{RESUM}

\section{LA PARTICIPACIÓ FEMENINA ALS SETGES DE SARAGOSSA. LA PERCEPCIÓ DEL COMANDAMENT MILITAR I L'INTERĖS DEL PODER POLÍTIC}

Aquest article estudia el paper desenvolupat per les dones combatents als Setges de Saragossa durant la Guerra de la Independència; el tipus d'accions en les quals van prendre part, les seues oportunitats per eixir de l'anonimat i el patiment durant i després de la contesa. A més, atén als diferents interessos de la mobilització femenina durant la batalla i a la posterior imatge de les heroïnes saragossanes, indagant al voltant de les motivacions de les mateixes protagonistes, dels comandaments militars de la plaça i del poder polític que, després de la guerra, va afrontar la construcció de l'estat lliberal.

Paraules clau: Guerra de la Independència, Setges de Saragossa, dones combatents, història de les dones. 
Los primeros años del siglo XIX estuvieron marcados en el Viejo Continente por los afanes expansionistas del general francés Napoleón Bonaparte, quien trató de exportar las ideas de la Revolución surgida en el país galo al resto de territorios europeos, y de paso, dominarlos.

En el complejo contexto que había sacudido desde finales de 1789 a su vecino del norte, la monarquía hispana jugó un papel ambivalente, como aliado o enemigo de Francia, en función del cariz que tomaban los acontecimientos en el territorio galo. Fruto del tratado de Fontainebleau, que acordaba la invasión hispano francesa de Portugal, tradicional aliado británico, los Ejércitos napoleónicos entraron en la Península y, en su camino hacia el hostil territorio luso, fueron estableciéndose en diferentes ciudades y plazas fuertes estratégicas hispanas.

Cuando los incidentes entre las tropas extranjeras y la población hispana y la inestabilidad política surgida por la debilidad de la monarquía ante las pretensiones del Emperador provocaron el levantamiento de diversas poblaciones contra los invasores, Aragón y su capital, tradicionalmente recelosos hacia sus fronterizos vecinos meridionales, mantuvieron una actitud de abierta hostilidad hacia los Ejércitos franceses. Fruto de ese posicionamiento fueron los dos Sitios que entre junio y agosto de 1808 y diciembre de ese mismo año y febrero del siguiente vivió Zaragoza. ${ }^{1}$

1 Sobre el asunto, sirven de referencia MARTíNEZ RUIZ (2008a; 2008b). 
Los planteamientos tácticos y estratégicos de aquel momento primaban unos usos de la guerra que daban protagonismo a las batallas en campo abierto, con la infantería como reina de las mismas, apoyada por la artillería. ${ }^{2}$ En ese contexto, el anterior predominio de las guerras de sitio había quedado superado. Si los asedios habían sido una constante en las guerras hasta el siglo XVIII, a principios del XIX ya tenían menor relevancia ante los avances técnicos logrados en las armas de fuego. Sin embargo, durante la Guerra de la Independencia española hubo un importante número de sitios tanto de plazas fuertes como de puestos fortificados (ESCRIBANO, 2009: 196). ${ }^{3}$ En parte, porque todos ellos continuaban siendo importantes para controlar los territorios y localidades adyacentes (MEDINA, 2009: 285). ${ }^{4}$

Ciertamente, no parece que la capital aragonesa fuera un lugar idóneo para resistir el asedio de la Grande Armée. Como otras grandes ciudades de vasto perímetro, su fortificación había quedado completamente obsoleta para los usos bélicos de aquel momento. En palabras del citado Francisco Escribano, más que fortificada, la ciudad estaba rodeada "por tapias de conventos, lienzos de murallas (romanas, árabes o de la Reconquista) y unas puertas cuya función no era defensiva sino fiscal, pues con ellas sólo se pretendía cobrar los aranceles a quienes quisieran comerciar en su interior" (ESCRIBANO, 2009: 200). ${ }^{5}$

Aun así, Zaragoza ofreció una feroz resistencia ante los franceses, y su lucha contra un enemigo muy superior sirvió de acicate a los combatientes de otros puntos de la Península a la hora de plantar cara al avance de las tropas napoleónicas. Una de las características de aquella lucha fue

2 Véanse BLACK (2000: 157 y ss.); y HOWARD (2009: 75 y ss.).

3 Para profundizar en aspectos técnicos de los asedios en aquellos años, también resulta muy interesante el estudio de HERRERO (2001).

4 Sobre los asedios a urbes durante el conflicto que nos ocupa, Andrés Cassinello señalaba: "Nuestra Guerra de la Independencia fue el último recurso generalizado a este tipo de guerra, que tuvo su final en Sebastopol o Stalingrado. En Cataluña se produjeron los Sitios de Girona, Lleida, Tarragona, Rosas, Tortosa, y un puñado más de poblaciones y fortalezas; en Valencia, la misma capital, Peñíscola y Murviedro; en León, Astorga y Ciudad Rodrígo; en Extremadura, Badajoz y Olivenza; en Andalucía, Cádiz y Tarifa, y en Aragón, por dos veces, Zaragoza" (CASSINELLO, 2007: 85).

5 En similar sentido, interesa la referencia en SANTACARA (2005: 68). Miguel Alonso Baquer resumía las operaciones españolas durante la Guerra de la Independencia distinguiendo tres tipos: las operaciones propias de un Ejército regular, las propias del viejo sistema defensivo de las milicias provinciales (centradas en la protección de las ciudades), y las operaciones del movimiento guerrillero que fue surgiendo tras la invasión napoleónica (ALONSO, 2009: 33). 
la implicación del conjunto de la población en el empeño por detener al enemigo e imposibilitar su avance por la ciudad. ${ }^{6} \mathrm{Y}$ dentro de ella, la participación femenina adquirió un lugar destacado.

\section{LAS COMBATIENTES DE LOS Sitios de ZaRAgoza}

Es lugar común afirmar que las mujeres, desde tiempos inmemoriales, han tomado partido en las guerras, sobre todo en labores de aprovisionamiento y de atención a las tropas (NASH y TAVERA, 2003; FERNÁNDEZ, 2010). Sin embargo, dicha actuación tiene como principal característica el anonimato de sus protagonistas. Frente a ello, los Sitios de Zaragoza van irremediablemente asociados a nombres como los de Agustina Zaragoza, Manuela Sancho, María Agustín, Casta Álvarez, la condesa de Bureta o la madre Rafols, entre otras.?

Una presencia, la de estas mujeres, que ha pervivido en la memoria colectiva o en el callejero de la ciudad, y que ya desde los primeros momentos fue documentada por los testigos de la misma. Entre estos testimonios de la resistencia de la urbe aragonesa, los padecimientos de su población y la implicación colectiva en la lucha, incluida la femenina, destacaron los pictóricos, en especial los grabados de Francisco de Goya en su serie Desastres de la Guerra, o de Juan Gálvez y Fernando Brambila en Las Ruinas de Zaragoza. ${ }^{8}$ De igual modo, durante la Guerra de la Independencia y en los años posteriores, las autoridades militares y civiles que habían asumido algún tipo de mando castrense en los Sitios de Zaragoza emitieron certificaciones e

6 Un levantamiento de los habitantes de la ciudad que recuerda el concepto de nación en armas que precisamente la Revolución Francesa acabó exportando al resto del continente. Entre la abundante bibliografía relativa a dicho concepto o su aplicación a la Guerra de la Independencia española, pueden ser de utilidad BEST (1990: 156); HOCQUELLET (2008: 134 y ss.); RÚJULA (2009); y KEEGAN (2014: 465-470). Una interesante visión sobre la extensión del combate al conjunto de la sociedad y su trágica consecuencia del mayor alcance de la violencia al conjunto de la misma, en RÚJULA (2012: 35). Sobre la presencia popular en la guerra de sitio, Richard Hocquellet y Stéphane Michonneau apuntaban: "La raison de cet enthousiasme vient de ce que la guerre de siège met en valeur la composante civique du conflit. Le siège s'installe dans la durée et repose sur la cohésion et l'organisation de la résistance du pueblo" (HOCQUELLET Y MICHONNEAU, 2008: 103).

7 Sobre ellas, sirven de referencia, LAFOZ (1996: 226); AYMES (2008: 356-364); ESPIGADO (2009: 715 y ss.); FERNÁNDEZ (2009b: 44-66); y MARÍN (2009).

8 La imagen visual de la Guerra de la Independencia ha sido analizada por REYERO (2008). También merecen atención los escritos producidos en aquellos años por el cronista de la ciudad, Faustino Casamayor y Ceballos. 
informaciones sobre el activo papel de estas heroínas. Numerosos escritos reflejaron las meritorias acciones protagonizadas por la más afamada de aquellas protagonistas femeninas de la resistencia aragonesa frente a los franceses: Agustina Zaragoza Doménech. Por ejemplo, el capitán del Regimiento de Dragones del Rey, don José López de Ansó, señalaba de ella:

"se me presentó en el mes de Junio de 1808 luego que los enemigos sitiaron la Ciudad [...] se ofrecio voluntariamente á hacer el servicio que pudiese en la Puerta del Portillo, lo que verificó con un valor extraordinario, particularmente en el $1^{\circ}$ de Julio del mismo año en que atacando los enemigos con el mayor impetu dicho punto para penetrar en la Ciudad; y habiendo mucha falta de Artilleros por haber perecido algunos de los pocos que habia con la multitud de bombas y granadas que dirigian sobre la bateria, viendo la citada Zaragoza se aproximaban y no habia quien diese fuego á un cañon que estaba cargado, tomó la mecha y disparó, causandoles una gran perdida, y obligandoles á que se retirasen". 9

También es sobradamente conocida la información sobre Manuela Sancho dada por don Mariano de Renovales, en calidad de comandante del fuerte de San José, al general Palafox, en la que recogía como esta:

"tanto en el ataque del dia último de año pasado, como en el de ayer

9 El referido Oficial continuó su relato con la participación de la Heroína en el Segundo Sitio de la ciudad, donde prestó sus servicios nuevamente en la puerta del Portillo, para proseguir luego sus desvelos en la Misericordia y en el convento de Trinitarios. Archivo Municipal de Zaragoza (en adelante AMZ), fondo Palafox, sig. 3-5/3, año 1814. De esta protagonista se conservan otras certificaciones en similar sentido emitidas por autoridades militares de diferentes lugares o enfrentamientos contra los franceses. Sirvan de ejemplo las rubricadas por el conde de Alacha, de la presencia de Agustina Zaragoza en la defensa de la plaza de Tortosa de 1810 (AMZ, fondo Palafox, sig. 3-5/4, año 1814), o por el mariscal de campo Pablo Morillo, de sus buenos servicios en la batalla de Vitoria (AMZ, fondo Palafox, sig. 3-5/5, año 1814). Mención aparte merece la celebérrima y muy posterior certificación de don José Rebolledo de Palafox y Melci, Capitán General del Ejército y Reino de Aragón, en la que acreditaba el valor y patriotismo exhibidos por Agustina durante los Sitios de la capital, distinguiendo especialmente su citada actuación de primero de julio en la batería del Portillo, así como la concesión por el propio Palafox de la graduación y el sueldo que gozaba el sargento de Artillería a quien la heroína había tan dignamente reemplazado en su afamada acción. $A M Z$, fondo Palafox, sig. 3-5/8, año 1833. 
sirvió la artillerìa y mortero como pudiera haberlo hecho el mejor artillero, conduciendo cartuchos para los unos, y piedras para el otro, sin haberle notado la menor mutacion, á pesar de haber caído algunos a su lado: dió fuego á algunos cañones, y lo hizo de fusil en la trinchera como uno de tantos". ${ }^{10}$

Otras protagonistas no son tan conocidas como las anteriores, pero no por ello ganaron menos méritos. Además, sus acciones también eran certificadas por diferentes testigos. Fue el caso de doña María Ramírez de Arellano, quien junto a su hijo Juan Puch, hizo gala de patriotismo y sacrificio en los dos Sitios de la ciudad. Por ello, el mariscal de campo don Francisco Marco del Pont, en calidad de comandante que había sido de la batería del Portillo, daba cuenta que:

"doña Maria Ramirez de Puch pasó en el primer Sitio á llevar biveres y municiones á la expresada bateria en medio de los mayores riesgos, manifestando siempre mucho patriotismo y celo por la justa causa" ${ }^{\prime 1}$

Sobre Josefa Buil, Luis Lapuente, el alcalde de barrio de la parroquia de la Magdalena que había comandado una porción de paisanos contra los franceses, afirmaba que:

"Josefa Buil fue una de las mugeres que mas se distinguieron en el segundo asedio de esta ciudad en los puntos del arco de Valencia y plaza de la Magdalena, y que dicha Buil hacia las fatigas correspondientes como uno de los mejores soldados tanto de dia como de noche". ${ }^{12}$

10 Recogido en Gaceta de Zaragoza, 7 de enero de 1809. Como esta, Manuela Sancho recibió otras certificaciones de su actuación y su valor durante los Sitios de la ciudad por parte del general Palafox, del brigadier don Alberto Sagastibelza o del duque de Villahermosa, que era coronel de Dragones. AMZ, fondo Palafox, sig. 3-10/2, año1818, ff. 1r-2r, 3r y 4r y v, respectivamente.

11 El papel de doña María también fue certificado por don Fernando Gómez de Butrón, mariscal de campo de los Reales Ejércitos. Ambas citas en AMZ, fondo Palafox, sig. 21-4/2-3, años 1814-1817, f. 1r y 3r, respectivamente. También fue recogida su actividad en $A M Z$, fondo Palafox, sig. 13-6/51, año 1817, f. 10r y v. y sig. 13-2/82, año 1817, f. 1ry v. 
Como puede observarse en las diferentes citas, los jefes militares que habían sido testigos de las acciones de las vecinas de Zaragoza durante los Sitios de la ciudad recogían una variada actividad de las mismas. Como es lógico, se reflejó su papel en las labores de atención a las necesidades de la tropa que directamente combatía. Teresa García, una vecina de la parroquia de Santa Engracia de la ciudad, había asistido pública y notoriamente "en el tiempo de los ataques de esta ciudad, con refresco á las tropas de las Baterias, y Puertas." ${ }^{13} \mathrm{Y}$ de la condesa de Bureta, en particular, y otras muchas zaragozanas en general se escribía en uno de los muchos relatos épicos de los Sitios zaragozanos:

"Las mugeres se conduxeron como heroinas, simpatizando admirablemente con el valor y gallardía de los hombres. La Condesa de Bureta, Dama distinguida del pais, viuda del Conde de este título, y esposa en el dia del Regente de la Real Audiencia de Aragon, formó un cuerpo con las de su sexô destinadas únicamente á socorrer á los heridos, y á llevar vino y provisiones á los soldados. Muchas personas fidedignas declaran, haber visto á menudo esta muger delicada y bella llenando con mucha serenidad los deberes que se habia impuesto en medio del fuego, de las balas, bombas y granadas del enemigo". ${ }^{14}$

En otras ocasiones, la participación de estas heroínas fue ambivalente, dedicándose principalmente a labores de abastecimiento, más propias de su sexo en la escala de valores de la época, pero no dudando en empuñar las armas ante la necesidad de ello. De Manuela Sancho se refleja como:

$12 Y$ en similares términos se expresaba uno de los mayordomos del Hospital de Niños Huérfanos de la ciudad, presente en la contienda. AMZ, fondo Palafox, sig. 3-7/5, año 1818, f. 1ry lv, respectivamente.

13 AMZ, fondo Palafox, sig. 22-8/77, año 1808. Sobre ellas, véase RUDORFF (1977: 133).

14 AMZ, fondo Palafox, sig. 1-6/3, año 1809, f. 12r. Muy interesantes resultan, en este sentido, los informes de la condesa de Bureta describiendo su propia actuación durante la contienda. Véase MARÍN (1999: 98-100 y 107-109). De este tipo de participación femenina en la guerra, Elena Fernández señalaba: "aunque históricamente las mujeres siempre han llevado a cabo tareas de asistencia a los ejércitos, no será hasta el contexto de la Guerra de la Independencia cuando desde las instituciones militares y de gobierno se de relevancia pública a unas funciones que resultaban básicas para asegurar el triunfo de las tropas sobre el enemigo francés" (FERNÁNDEZ, 2011 b: 73). 
"Desde antes de romper el dia hasta que anochece no cesa de conducir, pan, vino, aguardiente, y otras frioleras; en los mayores apuros del ataque, se ha desentendido de este servicio, y se ha dedicado al de la artillería con la mayor serenidad, conduciendo municiones, y piedras à canastas para el mortero, dando fuego por sí à los cañones, y haciendolo por los parapetos con el fusil, sin que se le haya conocido la menor mutacion à pesar de haber caìdo algunos à su lado". ${ }^{15}$

E incluso, algunas de las certificaciones hacen referencia únicamente a las acciones militares que protagonizaron algunas de estas mujeres. En la declaración de la conducta observada en tres vecinas de la ciudad durante la contienda se recogía:

"Josefa Buil natural de Barbastro se halló en dicha ciudad durante el segundo asedio y la vi hacer fuego en una de las baterias de la plaza de la Magdalena en compañia de Benita Portoles natural de Alcañiz, y Teresa Liesa natural de Huesca, especialmente en la esquina de la calle de Palomar en cuya casa habitaba la expresada Benita Portoles". ${ }^{16}$

Toda esta documentación relativa a las mujeres que destacaron por su heroísmo durante los Sitios de la ciudad tuvo un único origen, pero muy diferentes finalidades. Respecto al origen de dicha documentación cabe señalar que fue la propia actuación "masiva" femenina la que provocó que aparecieran tantas listas de participantes en la resistencia de la ciudad ante los franceses en las que se incluían féminas, así como numerosas misivas en las que se hacía referencia a ellas, y un sinfín de certificados y notas avalando su conducta en la contienda. Frente al tradicional veto existente durante aquellos siglos a la participación femenina directa en los conflictos bélicos, los Sitios de Zaragoza constituyeron una interesante excepción. En

15 Gaceta de Zaragoza, 7 de enero de 1809, p. 14. También recogido en AMZ, fondo Palafox, sig. 47-13, año 1818.

16 AMZ, fondo Palafox, sig. 3-7/5, año 1818, f. 1v. Aunque el empuñamiento de las armas por manos femeninas no dejaba de ser un quebranto de los roles femeninos imperantes, como señalaba Juan José Sánchez "cuando la gente emprende un alzamiento, la ruptura del orden existente puede extenderse también a las barreras de género, que al fin y al cabo son injustas, discriminatorias y con frecuencia bastante arbitrarias" (SANCHEZ, 2008: 699). 
primer lugar, la neta superioridad del enemigo frente a las tropas atrincheradas en la ciudad facilitó la respuesta popular en ayuda y auxilio de los suyos para resistir el embate francés. Y dentro de esa respuesta popular, la dada por las propias vecinas tuvo su protagonismo.

Esta movilización provocó la cercanía física de las mujeres a los lugares de combate. ${ }^{17}$ Pese a que en un principio su papel pudo centrarse en labores de abastecimiento y sostenimiento a las tropas masculinas (las implicadas directamente en las operaciones), las mujeres cobraron relativa proximidad y familiaridad con la primera línea de frente y con las armas que finalmente acabaron enarbolando. De este modo, en gran medida, estas zaragozanas atrapadas dentro de su ciudad no pudieron, y quizá no quisieron, quedar al margen de la guerra que la asolaba. ${ }^{18}$

La primera finalidad de la citada documentación hay que buscarla en el intento de las interesadas de obtener alguna distinción o una pensión por los sufrimientos pasados y el patriotismo exhibido, o la concesión de las mismas por la autoridad pertinente.

Don José Palafox, por ejemplo, distinguió a Agustina Zaragoza con el escudo de defensora de la patria por su valor y los servicios prestados en la defensa de la ciudad. Y también se le concedió el permiso para usar la cruz de distinción de la participación en el Primer Sitio de Zaragoza. ${ }^{19}$ Además, la Junta Suprema Central de Gobierno de España e Indias, en nombre de Fernando VII, otorgó a Agustina Zaragoza el grado y sueldo de subteniente de Infantería. ${ }^{20}$

17 Acerca del papel femenino en el campo de batalla, Nira Yuval-Davis afirmaba: "Clear sexual division of labour in war, however, usually disappears when there is no clear differentiation between the battle front and the home front or rear" (YUVAL-DAVIS, 1997: 95).

18 Similar había sido la situación vivida pocos años antes por las mujeres que se vieron atrapadas en los acontecimientos de la Revolución Francesa, que en numerosos casos tomaron parte de los acontecimientos que se desarrollaban en su entorno (LEVY y APPLEWHITE, 1992; y BECKSTRAND, 2009). También interesante la reflexión recogida sobre estas mujeres en LYNN (2008: 208-214).

$19 \mathrm{AMZ}$, fondo Palafox, sig. 3-5/1, año 1808 y sig. 3-5/7, año 1817, respectivamente.

$20 \mathrm{AMZ}$, fondo Palafox, sig. 3-5/2, año 1809. Como se vio con anterioridad, el general Palafox certificó posteriormente haber concedido a Agustina, haciendo uso de las amplias facultades de las que gozó durante la contienda, y como estímulo al resto de defensores de la ciudad, ya durante el mismo asedio el grado y sueldo del sargento de Artillería al que tan dignamente había reemplazado. Véase nota 9. 
De igual modo, acabada la contienda, se recogieron informes y memoriales sobre la actuación de diferentes mujeres que participaron en la defensa de la ciudad y las solicitudes para premiarlas con las anteriormente citadas condecoraciones. Entre ellas se encontraban María Lostal, Eugenia Cubeño, María Gali, Benita Portolés, Manuela Barrena o Ana Sánchez. ${ }^{21}$

El propio Capitán General premió a Manuela Sancho con el "distintivo de la cinta encarnada" y media peseta diaria de pensión. ${ }^{22}$ Y lo mismo hizo con Josefa Buil, a la que otorgó una pensión de cinco reales de vellón diarios "en premio de su celo, y continuo trabajo en las Baterias, haciendo el mismo servicio que un soldado." 23

También reclamaba una pensión de viudedad María Montalbán, una zaragozana que había tenido una heroica actuación durante los dos Sitios, habiendo perdido en el segundo a su marido, señalando entre sus méritos:

"que la recurrente se ocupó en los dos [Sitios], en conducir cartuchos á la Artilleria, y refrescos para los que ocupaban los puestos abanzados, depreciando la muerte que en todas direcciones la amenazaban, y que despues de rendida dicha Plaza se trasladó á la de Tortosa ejercitandose en iguales servicios". ${ }^{24}$

Similar situación en la que debía encontrarse María Paracuello, una viuda vecina de Zaragoza que también había perdido a su marido durante el segundo asedio a la ciudad. El general Palafox solicitó para ella la concesión de alguna limosna por los servicios que había prestado junto a su marido durante los Sitios. ${ }^{25}$

No menos importante que el propio interés de las protagonistas femeninas de las que venimos tratando fue el de las autoridades militares y civiles

21 AMZ, fondo Palafox, sig. 12/145-247, año 1814, sig. 10-1/29, año 1808, sig. 13-1/1-36, año 1815 y sig. 13-5/1-22, año 1815. Peticiones de premio a las que ni siquiera la ciudad fue ajena. Acabada la contienda, el consistorio zaragozano solicitaba al general Palafox su informe favorable a la petición de la capital aragonesa al rey para recibir los títulos de "muy noble, fidelísima y heroica". AMZ, fondo Palafox, sig. 13-2/1-2 y sig. 44-5/15, año 1817.

22 Gaceta de Zaragoza, 7 de enero de 1809, pp. 13-15.

$23 \mathrm{AMZ}$, fondo Palafox, sig. 3-7/3 y 4, año 1818 y sig. 3-7/8, año 1821.

$24 \mathrm{AMZ}$, fondo Palafox, sig. 3-8/72, año 1828, ff. $1 \mathrm{r}-2 \mathrm{r}$.

25 AMZ, fondo Palafox, sig. 46-17/45-46, año 1818. 
que quisieron extender el ejemplo de la población de Zaragoza y su tenaz resistencia a otras localidades y territorios peninsulares. ${ }^{26}$ La capital aragonesa se convirtió en paradigma de lucha, una pugna que había sido protagonizada por toda la sociedad, incluido el sector femenino. ${ }^{27}$ Así se certificó y publicó, para de ese modo provocar la movilización del esfuerzo popular (DE DIEGO, 2005: 15; CASTELLS, ESPIGADO y ROMEO, 2009: 16; FERNÁNDEZ, 201 1a: 45-46).

Fruto de aquel interés de las autoridades fue la construcción de auténticos mitos en torno a la figura de algunas de estas mujeres. La más clara muestra de ello fue, sin duda, Agustina de Aragón, cuya persona y actuación quedaron ensalzadas desde un primer momento por los propios protagonistas de los Sitios que compartieron lucha con ella. ${ }^{28}$ Posteriormente, Agustina ha sido citada y representada en todo tipo de obras, tanto literarias como historiográficas, pictóricas, escultóricas y cinematográficas, y por muy diferentes motivos, especialmente coincidiendo con la celebración de actos conmemorativos. ${ }^{29}$

De modo similar al caso de Agustina, otras mujeres que participaron en los Sitios de Zaragoza fueron, con nombres propios, ensalzadas como heroínas y su actuación sirvió como aglutinante de otras muchas acciones femeninas anónimas llevadas a cabo durante los enfrentamientos contra

26 Las diferentes tipologías de los diversos discursos patrióticos elaborados durante la Guerra de la Independencia española han sido analizadas por HOCQUELLET (2008: 11-15).

27 Como han señalado José Gregorio Cayuela y José Ángel Gallego, Zaragoza, además del mito popular y político que representó, destacó por suponer con su resistencia la continuación más destacada del 2 de mayo en Madrid, por primar el papel de la resistencia popular por encima del propio Ejército regular encabezado por el general Palafox y por convertirse en un importante referente no solo para el resto de poblaciones resistentes en la Península, sino para los propios franceses (CAYUELA y GALLEGO, 2008: 109-1 10). También resulta interesante, en este sentido, las vivencias expuestas por el oficial británico Charles Doyle, sobre la resistencia zaragozana que presenció en primera persona. Recogido en LASPRA (2010: 257).

28 En algunos casos, los testimonios procedieron incluso del bando francés, BELMAS (2003: 30); y LEJEUNE (2009: 14).

29 Entre los múltiples trabajos de análisis de estas obras, pueden ser de utilidad ÁLVAREZ BARRIENTOS (2009); SALAS (2007); ROMERO (2009); MARTíNEZ ÁLVAREZ (2010); y FREIRE (2014). El trato dado a las heroínas zaragozanas durante la conmemoración del centenario de la Guerra de la Independencia fue estudiado por MORENO LUZÓN (2004: 58 y ss.). María Pilar Queralt, por su parte, trató de separar, en su biografía de Agustina de Aragón, el papel histórico de la heroína y su personaje mitificado (QUERALT, 2008). 
los franceses en aquellos años (CAYUELA y GALLEGO, 2008: 115; SERRANO, 2010: 164-165). ${ }^{30}$ La actuación de todas estas mujeres valerosas fue un arma ampliamente utilizada por la propaganda patriótica y símbolo de la lucha popular por la libertad nacional (FERNÁNDEZ, 2009a: 794).

Obviamente, un análisis objetivo de este proceso mitificador también muestra ciertas fisuras en el mismo. La gesta de Agustina de Aragón, como ha puesto de manifiesto la historiografía, coincide con bastante fidelidad con el relato mítico de otras heroínas, como el de la norteamericana Molly Pitcher durante la Guerra de Independencia de las colonias británicas (CASTELLS, ESPIGADO y ROMEO, 2009: 29; UCELAY DA CAL, 2009: 213). ${ }^{31}$ Y tal como ha sido señalado por algún autor, algunas de las heroínas zaragozanas recibieron honores y pensiones tras realizar acciones corrientes entre los soldados, como reemplazar a un compañero caído, muestra de la excepcionalidad de ser protagonizados por mujeres y del interesado discurso movilizador de las autoridades (TONE, 1999: 263). María Pilar Queralt mostraba la mezcla de cotidianeidad y casualidad que se daba en la presencia de la propia Agustina en la capital aragonesa durante los Sitios de la ciudad. Al preguntarse qué hacía una joven catalana en Zaragoza, concluía: "Simplemente, seguir a su esposo. En la época era habitual que los soldados se trasladaran con sus esposas que, en caso de necesidad, colaboraban manteniendo la intendencia del regimiento". (QUERALT, 2005: 28-29). ${ }^{32}$

De igual manera, como puede observarse en lo tardío de algunas de las certificaciones citadas, el discurso mítico de la actuación de estas zaragozanas persistió bien entrado el siglo XIX, sirviendo de argumento al nacimiento del estado-nación liberal español (ÁLVAREZ JUNCO, 1994; 1997;

30 Mientras que en los primeros momentos de la Guerra de la Independencia la participación femenina tuvo algunos nombres propios, a lo largo del transcurso de la contienda, el discurso se fue alterando y se primó al grupo, dando prioridad a una iconografía de la feminidad menos amenazante (ESPIGADO, 2009: 722). Sobre la existencia de dos modelos de mujer, en buena medida antagónicos, en los discursos patrióticos de aquellos años, el de la matrona y el de la heroína, véase FERNÁNDEZ (2009a). También de interés, JIMÉNEZ (2005: 363-364); y ROMEO (2006: 63).

31 El papel femenino en la Guerra de la Independencia americana fue analizado por BOHRER (2003: 155 y ss.) y BERKIN (2005: 50-56).

32 En este caso, a su marido Juan Roca, implicado en varias de las acciones del Ejército en tierras catalanas y aragonesas. Sobre la llegada de Agustina a la Zaragoza, interesa QUERALT (2008: 71-72). 
2016: 155 y ss.; GARCÍA CÁRCEL, 2007; ÁlVAREZ JUNCO y DE LA FUENTE, 2017: 279-280). ${ }^{33}$ Roberto López Vela señalaba que: "En la mitología del siglo XIX los acontecimientos de la guerra contra los franceses ocupan un lugar central y en torno a su explicación se construye toda una imagen de la nación" (LÓPEZ VELA, 2004: 289). Una mitología nacionalista que los principales partidos decimonónicos supieron explotar en su beneficio. José Álvarez Junco observaba:

"La canonización del conflicto de 1808-1814 como Guerra de la Independencia, acabó dando lugar a un motín nacional casi perfecto, porque, tras ser una creación liberal, acabó sobrevolando por encima de los partidismos políticos. Los liberales siguieron basando en aquella actuación del pueblo su pretensión de construir un edificio político a partir del dogma de la soberanía nacional; pero los conservadores no dudaban en presentar la heroica pugna de 1808 como prueba de la fidelidad del pueblo español a la tradición heredada" (ÁLVAREZ JUNCO, 2001: 144). ${ }^{34}$

Además, el encumbramiento glorioso de las heroínas (como el que se hizo de destacados guerrilleros en particular y del pueblo en general) sirvió para desviar la atención sobre las deficiencias y carencias de las que adolecía el Ejército regular español, y su clara inferioridad frente al enemigo galo. ${ }^{35}$

Y, por último, no conviene olvidar el propio interés de algunas de las autoridades militares que generaron un discurso propagandístico que elevaba

33 La memoria de algunas heroínas se reavivó décadas después, en el momento de su deceso, como fue el caso de Manuela Sancho o el de la propia Agustina. AMZ, fondo Palafox, sig. 3-10/3, año 1863. De la primera se recordaba, en un artículo publicado con motivo de su óbito, "fué un ejemplo vivo y constante de patriotismo y de valor" durante los Sitios de la ciudad y se destacaba como en los momentos más dramáticos de la contienda "nuestra heroina empuña un fusil y olvidándose de su secso y recordando solo que es española, se bate vigorosamente por espacio de algunas horas y logra la dicha de que su nombre se cite como modelo en los partes del jefe del puesto y en los documentos oficiales de la época." Diario de Zaragoza, 2 de mayo de 1863.

34 También de interés FUENTES (2013: 183).

35 Sobre la situación del Ejército español que hubo de encarar la Guerra de la Independencia existe un interesante estudio en CASSINELLO (2008a: 231-235). 
la actuación de las zaragozanas y los zaragozanos al nivel de gesta épi$\mathrm{ca}$, para de ese modo ensalzar la suya propia o incluso hacer olvidar los posibles errores cometidos en el ejercicio del mando durante los célebres asedios a la ciudad.

El caso paradigmático, en este sentido, fue el del general Palafox, cuya figura y papel durante la Guerra de la Independencia han recibido una importante revisión historiográfica. ${ }^{36}$ Palafox ha sido definido como "un aristócrata militar dotado de mayor talento y vocación políticos que castrenses", empeñado, durante los años posteriores a la contienda, en un infructuoso intento de escribir unas memorias para justificar su actuación y engrandecer su carrera militar (que no fue brillante) con su protagonismo en los Sitios de Zaragoza (LAFOZ, 1992: 40; DURÁN, 2002: 73-74; CUENCA, 2006: 135).

El relato del General recoge su interés en encumbrar la resistencia al asedio de la capital aragonesa junto a los más relevantes episodios bélicos de este tipo acaecidos a lo largo de nuestra historia, remarcando su propio protagonismo en el mismo:

"La primera plaza, el primer pueblo, que sostuvo por dos veces el más heroico y empeñado sitio que cuentan nuestros anales militares, incluso Sagunto y Numancia, fue Zaragoza, siendo yo el encargado de dirigir su defensa".

Igualmente, Palafox trató de justificar su quizá excesivo entusiasmo a la hora de loar la resistencia zaragozana al ataque galo:

"Los dos Sitios de Zaragoza ocuparán siempre interesantes trozos de nuestra historia; nuestros hijos, al leerlos, se creerán mágicamente transportados a los tiempos heroicos, y es tolerable si nos exaltamos algún tanto al recordar memorias tan preciosas. Lícita le es al hombre la ambición de gloria, séale pues permitido igualmente el recordar a sus semejantes aquellos hechos en que tuvo tanta parte, señalándose en tan grandiosas hazañas" (PALAFOX, 1994: 34 y 36, respectivamente)..$^{37}$

36 Al respecto, son de interés ESDAILE (2004: 201); DURÁN (2008); y GARCÍA CÁRCEL (2010: 30).

37 Manuel Moreno Alonso destacaba la ausencia de cualquier autocrítica del General a su propia actuación al elaborar su relato autobiográfico (MORENO ALONSO, 2008: 23). 
Algún autor, incluso, ha destacado lo erróneo de su escasa actuación durante la Guerra de la Independencia, desde sus fracasos en los enfrentamientos regulares abiertos contra los franceses en el frente del Ebro, hasta la absurda decisión de atrincherarse en una ciudad como Zaragoza y mantener una defensa de la misma que supuso un enorme desgaste humano y que tuvo una nula utilidad militar (CASSINELLO, 2006: 71 y 76; 2008b: $131) .{ }^{38}$

Y haciendo referencia específicamente a la participación femenina en la contienda, la postura del general Palafox no debió ser muy favorable en principio, aunque también es cierto que no tardó en mudar su opinión. Gloria Espigado advertía:

"En verdad, las primeras reacciones ante la iniciativa femenina fueron, como cabría esperar, de rechazo. Las autoridades recriminaron, en primera instancia, la salida de tono de las mujeres y las conminaron a permanecer en su lugar dentro del recinto doméstico. Palafox, en los inicios del primer embate a la ciudad, también ordena que niños, mujeres y ancianos permanezcan en sus casas, pero he aquí que es el primero en cambiar de opinión y percatarse del potencial que encierra no sólo la participación femenina, sino la noticia de la participación femenina, para a partir de ahí aconsejar y animar su implicación" ${ }^{39}$

En cualquier caso, Palafox fue un personaje complejo cuyo origen nobiliar, su educación ilustrada y su defensa del rey despertaron desconfianzas entre los sectores populares y entre las élites, tanto liberales como conservadoras. Y aunque ocupó la Capitanía General de Aragón durante los Sitios y la recuperó tras la contienda, en 1815 se vio obligado a retirarse de la misma y fue viendo frustradas muchas de sus expectativas. Como indicó Pedro Rúiula: "Poco a poco Palafox tuvo que acostumbrarse a ocupar siempre aquella posición que no deseaba" (RÚJULA, 1994: 11).

No hizo, por otra parte, el antiguo Capitán General otra cosa que tratar de aprovecharse de los acontecimientos desarrollados durante los Sitios de Zaragoza y del ascendiente del que gozaban las mujeres que habían

38 Igualmente interesante la crítica realizada por PEIRÓ (2017). También existen estudios que defienden la labor militar de Palafox, como por ejemplo, PERLA (2009).

39 ESPIGADO (2009: 721). 
combatido en ellos. Poco difirió su actitud con la que tuvieron las diferentes facciones políticas que se disputaron el poder en la España del XIX, así como diversas instituciones, entre las que destacaron la Iglesia y la Corona.

\section{CONCLUSIONES}

Por lo hasta aquí visto, puede concluirse que la documentación conservada de los Sitios de la ciudad de Zaragoza en la Guerra de la Independencia española evidencia la participación de sus vecinas durante ambos asedios. Dicha participación se centró en labores logísticas y de apoyo a las tropas masculinas que hacían frente al enemigo francés. Sin embargo, la proximidad femenina a la primera línea de combate también les brindó la ocasión de sobresalir en las destacadas actuaciones militares que se desarrollaron durante los Sitios. Su participación y el sufrimiento que les acarrearon algunas de sus hazañas bélicas les permitieron salir del anonimato que caracterizaba la actuación femenina en las contiendas de aquellos siglos.

Además, tales acciones fueron reconocidas por las autoridades militares, quienes expidieron numerosos documentos certificando las hazañas realizadas por aquellas destacadas mujeres. Un buen número de estos documentos se debieron a un interés personal de las propias afectadas, que de esa manera justificaban la concesión de distinciones y pensiones que consideraban merecer por sus heroicas conductas durante la guerra. Buscaron con ello paliar la pobre situación en la que muchas de ellas quedaron tras la retirada francesa, agravada en muchos casos por la pérdida de familiares y bienes durante los Sitios.

En otras ocasiones, el interés provino de las propias autoridades militares y civiles que trataron de elaborar un discurso patriótico que en un primer momento sirviera de acicate movilizador de la mayor parte de la población contra la invasión napoleónica, para posteriormente utilizarlo en la propia construcción nacional del estado liberal a lo largo de todo el siglo XIX.

Frente a un enemigo netamente superior al Ejército español existente en la época, las autoridades hispanas trataron de movilizar a toda la población contra los franceses. Y en ese contexto, Zaragoza y sus habitantes, entre ellos y con nombre propio un buen puñado de mujeres, supusieron un ejemplo mitificado que corrió por la Península y se convirtió en símbolo de la resistencia de todo un pueblo contra la invasión.

Una labor propagandística de la resistencia de la capital aragonesa que tuvo como uno de sus principales promotores a quien encabezaba su Ejército, el general Palafox. Un militar cortesano al mando de una tropa muy inferior a la que tenía que hacer frente, con la necesidad de resistir el sitio de una ciudad mal fortificada, y en la que el impulso y sacrificio de la 
población explican buena parte del coste que la toma de la plaza supuso para los franceses. En las décadas siguientes, Palafox trató de manejar con astucia las circunstancias que caracterizaron los Sitios para justificar sus decisiones y añadir lustre a su propia actuación, encumbrando al tiempo a algunas de sus protagonistas a la categoría de mito.

Y ese mismo mito patriótico que había servido para movilizar a la población contra el invasor foráneo se utilizó a lo largo de todo el siglo decimonónico y los albores del XX para un discurso nacional que sirviera de justificación de la creación de un estado liberal.

\section{Bibliografía}

ALONSO BAQUER, Miguel (2009), "La conducción de las operaciones en la Guerra de la Independencia", en MARTíNEZ RODA, Federico (ed.), Actas del Congreso sobre la Guerra de la Independencia y los cambios institucionales, Diputación de Valencia, Valencia, pp. 29-49.

ÁLVAREZ BARRIENTOS, Joaquín (2009), "1808-1814. Escritores en guerra. El concurso literario por los Sitios de Zaragoza", en DE DIEGO, Emilio (dir.) y MARTÍNEZ SANZ, José Luis (coord.), El comienzo de la Guerra de la Independencia. Congreso Internacional del Bicentenario, Editorial Actas, Madrid, pp. 589-626.

ÁLVAREZ JUNCO, José (1994), "La invención de la Guerra de la Independencia", Studia Historica - Historia Contemporánea, vol. XII, pp. 75-99.

ÁlVAREZ JUNCO, José (1997), "El nacionalismo español como mito movilizado. Cuatro guerras", en CRUZ, Rafael y PÉREZ LEDESMA, Manuel (eds.), Cultura y movilización en la España contemporánea, Alianza, Madrid, pp. 35-67.

ÁlVAREZ JUNCO, José (2001), Mater dolorosa. La idea de España en el siglo XIX, Taurus, Madrid.

ÁlVAREZ JUNCO, José (2016), Dioses útiles. Naciones y nacionalismos, Galaxia Gutenberg, Barcelona.

ÁLVAREZ JUNCO, José y DE LA FUENTE, Gregorio (2017), El relato nacional. Historia de la Historia de España, Taurus, Madrid.

AYMES, Jean-René (2008), La Guerra de la Independencia: héroes, villanos y víctimas (1808-1814), Milenio, Lleida.

BECKSTRAND, Lisa (2009), Deviant Women of the French Revolution and the Rise of Feminism, Fairleigh Dickinson University Press, Madison.

BELMAS, Jacques (2003), Zaragoza, 1808 y 1809. Los Sitios vistos por un francés, Estudio, prólogo y notas de Herminio Lafoz, Editorial Comuniter, Zaragoza. 
BERKIN, Carol (2005), Revolutionary Mothers. Women in the Struggle for America's Independence, Knopf Book, Nueva York.

BEST, Geoffrey (1990), Guerra y sociedad en la Europa revolucionaria: 1770-1870, Ministerio de Defensa, Madrid.

BLACK, Jeremy (2000), War and the World. Military Power and the Fate of Continents, 1450-2000, Yale University Press, New Haven/Londres.

BOHRER, Melissa L. (2003), Glory, Passion and Principle. The Story of Eight Remarkable Women at the Core of the American Revolutions, Atria Books, Nueva York.

CASSINELLO, Andrés (2006), "El ejército español en la Guerra de la Independencia: un análisis militar", El Basilisco. Revista de Filosofía, Ciencias Humanas, Teoría de la Ciencia y de la Cultura, n 38, 2ª́poca, pp. 65-76. CASSINELLO, Andrés (2007), "Evolución de las campañas militares", en MOLINER PRADA, Antonio (ed.), La Guerra de la Independencia en España (1808-1814), Nabla Ediciones, Barcelona, pp. 73-122.

CASSINELLO, Andrés (2008a), "El ejército español en la Guerra de la Independencia", Revista General de Marina, vol. 255, pp. 23 1-242.

CASSINELLO, Andrés (2008b), "El mando supremo de los ejércitos españoles en la Guerra de la Independencia", en MIRANDA, Francisco (coord.), Guerra, sociedad y política (1808-1814), vol. I, Universidad Pública de Navarra/Gobierno de Navarra, Pamplona, pp. 121-150.

CASTELLS, Irene, ESPIGADO, Gloria y ROMEO, María Cruz (2009), "Heroínas para la patria, madres para la nación: mujeres en pie de guerra", en CASTELLS, Irene, ESPIGADO, Gloria y ROMEO, María Cruz (coords.), Heroínas y patriotas. Mujeres de 1808, Cátedra, Madrid, pp. 15-54.

CAYUELA, José Gregorio y GALLEGO, José Ángel, (2008), La guerra de la independencia: historia bélica, pueblo y nación en España (1808-1814), Ediciones Universidad de Salamanca, Salamanca.

CUENCA TORIBIO, José Manuel (2006), La Guerra de la Independencia: un conflicto decisivo (1808-1814), Encuentro, Madrid.

DE DIEGO, Emilio (2005), "La España de 1808: entre el mito y la realidad", Revista de Historia Militar, n extraordinario «Entre el Dos de Mayo y Napoleón en Chamartín: Los avatares de la guerra peninsular y la intervención británica», pp. 13-33.

DURÁN, Fernando (2002), "Las fuentes autobiográficas españolas para el estudio de la Guerra de la Independencia", en MIRANDA, Francisco (coord.), Fuentes documentales para el estudio de la Guerra de la Independencia, Ediciones Eunate, Pamplona, pp. 47-120. 
DURÁN, Fernando (2008), "Revolución busca caudillo: Palafox y los Sitios de Zaragoza", en ÁLVAREZ BARRIENTOS, Joaquín (ed.), La Guerra de la Independencia en la cultura española, Siglo XXI, Madrid, pp. 23-53.

ESCRIBANO, Francisco (2009), "Los Sitios en la Península Ibérica (18081814): mucho más que mitos", Revista de Historia Militar, $n^{\circ}$ extraordinario "La Guerra de la Independencia. Una visión militar», pp. 195-237.

ESDAILE, Charles J. (2004), La Guerra de la Independencia. Una nueva historia, Crítica, Barcelona.

ESPIGADO, Gloria (2009), "Armas de mujer: El patriotismo de las españolas en la Guerra de la Independencia", en DE DIEGO, Emilio (dir.) y MARTíNEZ SANZ, José Luis (coord.), El comienzo de la Guerra de la Independencia. Congreso Internacional del Bicentenario, Editorial Actas, Madrid, pp. 709-749.

FERNÁNDEZ GARCÍA, Elena (2009a), "Dos modelos de feminidad en las defensoras de la patria: las mujeres en los discursos patrióticos", en DE DIEGO, Emilio (dir.) y MARTíNEZ SANZ, José Luis (coord.), El comienzo de la Guerra de la Independencia. Congreso Internacional del Bicentenario, Editorial Actas, Madrid, pp. 773-798.

FERNÁNDEZ GARCÍA, Elena (2009b), Mujeres en la Guerra de la Independencia, Sílex, Madrid.

FERNÁNDEZ GARCÍA, Elena (2010), "Mujer y guerra. Un breve balance historiográfico", en VIGUERA, Rebeca (ed.), Dos siglos de historia: actualidad y debate histórico en torno a la Guerra de la Independencia (1808. 1814), Universidad de la Rioja, Logroño, pp. 195-210.

FERNÁNDEZ GARCÍA, Elena (201 la), "Historia y memoria de las mujeres asediadas", Cuestiones de género: de la igualdad y la diferencia, $\mathrm{n}^{\circ} 6$, pp. 35-50.

FERNÁNDEZ GARCÍA, Elena (2011b), "Mujeres sitiadas. La compañía de Santa Bárbara de Girona", Dossiers Feministes, n 15, pp. 63-75.

FREIRE, Ana María (2013), "La imagen de los personajes históricos de la Guerra de la Independencia en la literatura dramática del siglo XIX", Historia y Política, $n^{\circ} 29$, pp. 75-101.

FUENTES, Juan Francisco (2013), "Conceptos previos: Patria y nación en los orígenes de la España contemporánea", en MORALES MOYA, Antonio, FUSÍ, Juan Pablo y DE BLAS, Andrés (dirs.), Historia de la nación y del nacionalismo español, Galaxia Gutemberg, Barcelona, pp. 169-196.

GARCÍA CÁRCEL, Ricardo (2007), El sueño de la nación indomable. Los mitos de la Guerra de la Independencia, Temas de Hoy, Madrid.

GARCÍA CÁRCEL, Ricardo (2010), "Los mitos de la Guerra de la Indepen- 
dencia", en BORREGUERO, Cristina, La Guerra de la Independencia en el mosaico peninsular (1808-1814), Universidad de Burgos, Burgos, pp. 21-46.

HERRERO, José Vicente (2001), "La guerra de fortalezas en el periodo napoleónico (1796-1815)", Revista de Historia Militar, n 91, pp. 129-158. HOCQUELLET, Richard (2008), Resistencia y revolución durante la Guerra de la Independencia. Del levantamiento patriótico a la soberanía nacional, Prensas Universitarias de Zaragoza, Zaragoza.

HOCQUELLET, Richard y MICHONNEAU, Stéphane (2008), "Le héros de guerre, le militaire et la nation", Mélanges de la Casa de Velázquez, $\mathrm{n}^{\circ}$ 38:1, pp. 95-114.

HOWARD, Michael (2009), War in European History, Oxford University Press, Oxford.

JIMÉNEZ, Ana María (2005), "«Los otros combatientes» en la Guerra de la Independencia: el papel femenino", en CASTAÑEDA, Paulino (coord.), Las Guerras en el primer tercio del siglo XIX en España y América. XII Jornadas Nacionales de Historia Militar, tomo II, Deimos, Madrid, pp. 347-365.

KEEGAN, John (2014), Historia de la guerra, Turner, Madrid.

LAFOZ, Herminio (1992), José de Palafox y su tiempo, Diputación General de Aragón, Zaragoza.

LAFOZ, Herminio (1996), La Guerra de la Independencia en Aragón: del Motín de Aranjuez a la capitulación de Zaragoza (marzo 1808-febrero 1809), Institución Fernando el Católico, Zaragoza.

LASPRA, Alicia (2010), La Guerra de la independencia en los archivos británicos del "War Office": colección documental, Ministerio de Defensa, Madrid.

LEJEUNE, Louis-François (2009), Los Sitios de Zaragoza. Historia y pintura de los acontecimientos que tuvieron lugar en esta ciudad abierta durante los dos sitios que sostuvo en 1808 y 1809 , Edición de Pedro Rújula, Institución Fernando el Católico, Zaragoza.

LEVY Darline G. y APPLEWHITE, Harriet B. (1992), "Women and Militant Citizenship on Revolutionary Paris", en MELZER, Sara E. y KABINE, Leslie W (eds.), Rebel Daughters: Women and the French Revolution, Oxford University Press, Nueva York, pp. 79-101.

LÓPEZ VELA, Roberto (2004), "De Numancia a Zaragoza. La construcción del pasado nacional en las historias de España del ochocientos", en GARCÍA CÁRCEL, Ricardo (coord.), La construcción de las Historias de España, Fundación Carolina/Marcial Pons, Madrid, pp. 195-298. 
LYNN, John A. (2008), Women, Armies, and Warfare in Early Modern Europe, Cambridge University Press, Cambridge.

MARÍN ARRUEGO, Nuria (1999), La Condesa de Bureta, Comuniter, Zaragoza.

MARÍN ARRUEGO, Nuria (2009), Mujeres. Los Sitios de Zaragoza, Fundación Zaragoza 2008, Zaragoza.

MARTÍNEZ ÁlVAREZ, Josefina (2010), "La pervivencia de los mitos: la Guerra de la Independencia en el cine", Cuadernos de Historia Moderna. Anejos, n' IX, pp. 191-213.

MARTÍNEZ RUIZ, Enrique (2008a), "La Guerra de la Independencia española: planteamiento nacional y repercusión internacional", Monte Buciero 13. Cantabria durante la Guerra de la Independencia, Santander, pp. 17-43.

MARTÍNEZ RUIZ, Enrique (2008b), "La Guerra de la Independencia española (1808-1814): planteamiento y características de la crisis", Revista General de Marina, tomo 255, pp. 189-199.

MEDINA, Carlos J. (2009), "La artillería en la Guerra de la Independencia", Revista de Historia Militar, n extraordinario "La Guerra de la Independencia. Una visión militar», pp. 281-317.

MORENO ALONSO, Manuel (2008), "Prólogo", en PALAFOX, José de, Autobiografía, Ediciones Espuela de Plata, Sevilla, pp. 9-34.

MORENO LUZÓN, Javier (2004), "Entre el progreso y la virgen del Pilar. La pugna por la memoria en el centenario de la Guerra de la Independencia", Historia y Política, n 12, pp. 41-78.

NASH, Mary y TAVERA, Susana (2003), Las mujeres y las guerras, el papel de las mujeres en las guerras de la Edad Antigua a la Contemporánea, Icaria, Barcelona.

PALAFOX, José de (1994), Memorias, ed. de Herminio Lafoz Rabaza, Rolde de Estudios Aragoneses / Ayuntamiento de Zaragoza, Zaragoza.

PEIRÓ, Antonio (2017), El golpe de Estado del general Palafox, Prensas universitarias de Zaragoza, Zaragoza.

PERLA, José Luis (2009), "Estudio militar de la salida de Palafox de Zaragoza el día 4 de agosto de 1808", en VV.AA., La Guerra de la Independencia Española: una visión militar. Actas del VI Congreso de Historia Militar, vol. II, Ministerio de Defensa, Madrid, pp. 139-150.

QUERALT, María Pilar (2005), "Agustina de Aragón: entre la historia y el mito", Criaturas Saturnianas, n 3, pp. 25-35.

QUERALT, María Pilar (2008), Agustina de Aragón. La mujer y el mito, La Esfera de los Libros, Madrid. 
REYERO, Carlos (2008), "Visiones de la nación en lucha. Escenarios y acciones del pueblo y los héroes", en ÁlVAREZ BARRIENTOS, Joaquín (ed.), La Guerra de la Independencia en la cultura española, Siglo XXI, Madrid, pp. 105-129.

ROMEO, María Cruz (2006), "Destinos de mujer: esfera pública y políticos liberales", en MORANT, Isabel (dir.), Historia de las mujeres en España y América Latina, vol. 3, Cátedra, Madrid, pp. 61-83.

ROMERO, Leonardo (2009), "Los «Sitios de Zaragoza», tema literario internacional (1808-1814)", en DE DIEGO, Emilio (dir.) y MARTíNEZ SANZ, José Luis (coord.), El comienzo de la Guerra de la Independencia. Congreso Internacional del Bicentenario, Edirorial Actas, Madrid, pp. 571-588.

RUDORFF, Raymond (1977), Los Sitios de Zaragoza (1808-1809), Grijalbo, Barcelona.

RÚJULA, Pedro (1994), "Prólogo", en PALAFOX, José de, Memorias, edición de Herminio Lafoz, Rolde de Estudios Aragoneses / Ayuntamiento de Zaragoza, Zaragoza, pp. 9-14.

RÚJULA, Pedro (2009), "Guerra civil y pueblo en armas en los orígenes de la Guerra de la Independencia", en VV. AA., La Guerra de la Independencia Española: una visión militar. Actas del VI Congreso de Historia Militar, vol. I, Ministerio de Defensa, Madrid, pp. 43-52.

RÚJULA, Pedro (2012), "Zaragoza (1808-1809). El mito de la resistencia popular", en BUTRÓN, Gonzalo y RÚJULA, Pedro (eds.), Los sitios en la Guerra de la Independencia: la lucha en las ciudades, Sílex/Universidad de Cádiz, Madrid/Cádiz, pp. 15-37.

SALAS, María Pilar (2007), Descripción bibliográfica de los textos literarios relativos a los Sitios de Zaragoza, Institución Fernando el Católico, Zaragoza. SÁNCHEZ ARRESEIGOR, Juan José (2008), "Mujeres en la guerra", en MIRANDA, Francisco (coord.), Guerra, sociedad y política (1808-1814), vol. I, Universidad Pública de Navarra/Gobierno de Navarra, Pamplona, pp. 691-721.

SANTACARA, Carlos (2005), La Guerra de Independencia vista por los británicos (1808-1814), A. Machado Libros, Madrid.

SERRANO, Eliseo (2010), "Patriotas, héroes y vasallos. La Guerra de la Independencia en Aragón", en BORREGUERO, Cristina (coord.), La Guerra de la Independencia en el mosaico peninsular (1808-1814), Universidad de Burgos, Burgos, pp. 143-169.

TONE, John L. (1999), "Spanish Women in the Resistance to Napoleon 1808-1814", en ENDERS, Victoria Lorée y RADCLIFF, Pamela Beth (eds.), Constructing Spanish Womanhood. Female Identity in Modern Spain, State University of New York Press, Nueva York, pp. 259-282. 
UCELAY DA CAL, Enric (2009), "Agustina, la dama del cañón: el topos de la heroína fálica y el invento de patriotismo", en CASTELLS, Irene, ESPIGADO, Gloria y ROMEO, María Cruz (coords.), Heroínas y patriotas. Mujeres de 1808, Cátedra, Madrid, pp. 193-265.

YUVAL-DAVIS, Nira (1997), Gender \& Nation, Sage Publications, Londres. 


\title{
"SEREMOS HOMBRES Y FIERAS". MODELOS, ROLES Y ACTITUD DE LAS MUJERES DURANTE EL BLOQUEO Y ASEDIO AUSTRACISTA DE PENÍSCOLA (1706-1707)*
}

\author{
"WE WILL BE MEN AND BEASTS". MODELS, \\ ROLES AND THE ATTITUDE OF WOMEN DURING \\ THE AUSTRACISTS BLOCKADE AND SIEGE OF \\ PENÍSCOLA (1706-1707)
}

\author{
Javier Hernández Ruano \\ Universitat de València
}

\begin{abstract}
RESUMEN
Este trabajo analiza el significado de la actitud de las mujeres y la utilización propagandística de referentes simbólicos femeninos en la comunidad rural valenciana de Peníscola durante el período en que la fortaleza fue bloqueada en la Guerra de Sucesión Española. Para ese fin seguimos las aportaciones de la historiografía y utilizamos las dos únicas fuentes locales que lo permiten: una comedia proborbónica y el diario del comandante de la defensa. Finalmente se valora en qué medida las mujeres pudieron influir en el sostenimiento de la resistencia local.
\end{abstract}

Palabras clave: guerra de Sucesión, mujeres, historia de género, historia rural, Peníscola.

\begin{abstract}
This paper analyses the meaning of women's attitudes and the propagandistic use of female symbolic references in the rural Valencian community of Peniscola whose fortress was blocked during the Spanish Succession war. To that end we follow the contributions of historiography and use the only two local sources available: a pro-Bourbon comedy and the personal diary of the defence commander. Finally, the paper analyses the extent to which women could influence the maintenance of local resistance.
\end{abstract}

Key words: Spanish War of Succession, women, gender history, rural history, women, Peníscola.

\footnotetext{
Este artículo se enmarca en el proyecto de investigación del Departament d'Història Moderna i Contemporània de la Universitat de València "Privilegio, trabajo y conflictividad. La sociedad moderna de los territorios hispánicos del Mediterráneo occidental entre el cambio y las resistencias", PGC2018-094150-B-C21.
} 


\section{RESUM}

\section{"SEREM HOMES I FERES". MODELS, ROLS I ACTITUDS DE LES DONES DURANT EL BLOQUEIG I SETGE AUSTRACISTA DE PENÍSCOLA (1706-1707)}

Aquest treball analitza el significat de l'actitud de les dones i la utilització propagandística de referents simbòlics femenins en la comunitat rural valenciana de Peníscola durant el període en què la fortalesa va ser bloquejada en la Guerra de Successió Espanyola. Per a aquesta fi seguim les aportacions de la historiografia i utilitzem les dues úniques fonts locals que ho permeten: una comèdia proborbònica i el diari personal del comandant de la defensa. Finalment es valora en quina mesura les dones van poder influir en el sosteniment de la resistència local.

Paraules clau: guerra de Successió, dones, història de gènere, història rural, Peníscola. 
Si nos atuviésemos al discurso oficial que sobre lo femenino imperaba en la época de la Guerra de Sucesión Española (1702-1714) la mujer encauzaba su vida como esposa y madre, en una inseparable relación con un hombre. Era además una obligación que condicionaba su trabajo y función dentro de la familia. ${ }^{1}$ Este marco conceptual las apartó asimismo del interés de los historiadores coetáneos, y hasta no hace muchas décadas también de los contemporáneos, que negaban el papel de la mujer "como partícipe de la historia y no como uno de sus objetos". ${ }^{2}$ Sin embargo, como ha sabido mostrar la historiografía en los últimos decenios, las mujeres siempre habían participado incluso en el esfuerzo bélico. Los cronistas de la guerra de Sucesión no fueron ajenos a esa realidad y se refirieron a su participación activa. Sin embargo, la historiografía contemporánea las siguió ignorando durante mucho tiempo, olvidando la acertada mirada de los Brueghel y Grimmer al plasmar en sus pinturas escenas que evidenciaban con multitud de pormenores el protagonismo de la mujer también en la vida social y económica rural. ¿Desaparecían acaso del centro de la escena durante un tumulto, una revolución o en el transcurso de la guerra? Al margen del hito artístico, aquellas fidedignas representaciones reconocían a la mujer como sujeto histórico en igualdad con el hombre, y lo hacían además con las mujeres más olvidadas entre todas, las campesinas. Las mujeres cultas no dejaron de refugiarse durante los tres siglos siguientes en el teatro y la literatura frente a su confinamiento moral ${ }^{3}$ pero ya se había

1 HUFTON, Olwen (1992), "Mujeres, trabajo y familia", en DUBY, Georges y PERROT, Michelle (dir.), Historia de las mujeres en Occidente, Taurus, Madrid, pp. 23-66.

2 DAVIS, Natalie Zemon y FARGE, Arlette (1992), en DUBY y PERROT (dir.), Historia de las mujeres, p. 14.

3 DESAIVE, Jean-Paul (1992), "Las ambigüedades del discurso literario", en DUBY y PERROT (dir.), Historia de las mujeres, pp. 277-310. 
puesto en marcha la conocida como "querella de las mujeres", que conducirá a los ilustrados a proclamar la caducidad del concepto escolástico de la desigualdad inherente a los sexos, reformulándose simultáneamente los conceptos de masculinidad y feminidad. ${ }^{4}$

La historiografía no demasiado lejana en el tiempo presentaba al hombre como el auténtico hacedor de la Historia, más aún si el objeto de estudio era la guerra, un ámbito vinculado tradicionalmente al género masculino y sus pretendidas connotaciones asociadas al valor, lealtad, inteligencia, estrategia, liderazgo... Sin embargo, el nacimiento de la historiografía feminista rompió con ese molde en los años setenta del siglo pasado. En la actualidad, las investigaciones desde una perspectiva renovadora y de género sobre la mujer en cualquier etapa de la historia es una realidad consolidada en España, como nos muestran, por ejemplo, los estudios publicados en Asparkia y Arenal, ${ }^{5}$ cuya influencia alcanza a grupos de investigación de historia social no dedicados expresamente a una perspectiva de género. ${ }^{6}$ Estos planteamientos han desgranado la contribución femenina al desarrollo de la cultura occidental y su significado, lo que confirma que sólo una perspectiva que incluya a la mujer puede ayudarnos a conocer realmente "la sociedad del pasado". También la de una sociedad en guerra.

4 BOLUFER, Mónica (1995), "La construcción de la identidad femenina. Reformismo e llustración", Estudis. Revista de Historia Moderna, vol. 21, pp. 249-264; y BOLUFER, Mónica. (2000), "Galerías de mujeres ilustres o el sinuoso camino de la excepción a la norma cotidiana (ss. XV-XVIII)", Hispania. Revista Española de Historia, vol. 60, pp. 181-224.

5 CORONA, María Carmen y LÓPEZ, Antonio (2017), "Mujeres y saberes. En los límites de lo permitido: presentación", Asparkia, vol. 30, pp. 11-15; y MARTíNEZ, Cándida y NASH, Mary (2013), "ARENAL, 20 años de Historia de las Mujeres en España", Arenal, vol. 20, pp. $5-40$.

6 Como ejemplo, un reciente congreso sobre la sociedad moderna española. Cinco trabajos se ocupan de las mujeres: las empresarias de la confección y el abastecimiento en Madrid, la aportación de las mujeres al negocio familiar, el matrimonio en el mundo rural hispano, el protagonismo femenino en la concesión de encomiendas a través de la dote, y el espacio femenino ajeno a la casa. Véase AMELANG, James S., ANDRÉS, Fernando, BENÍTEZ, Rafael, FRANCH, Ricardo y GALANTE, Mirian (2018), (eds.), Palacios, plazas, patíbulos. La sociedad española moderna entre el cambio y las resistencias, Tirant Humanidades, Madrid.

7 LÓPEZ-CORDÓN, María Victoria (2014), "Los estudios históricos sobre las mujeres en la Edad Moderna: estado de la cuestión", Revista de Historiografía, vol. 22, 2015, p. 150. Un análisis sobre los estudios de género en relación a las aportaciones de la sociología, la antropología y específicamente sobre el mundo de lo privado y lo público en BOLUFER, Mónica y MORANT, Isabel (1998), "Historia de las mujeres e historia de la vida privada: confluencias historiográficas", Studia Historica. Historia Moderna, vol. 19, pp. 17-23. 
En el caso de Peníscola, una pequeña comunidad de labriegos y pescadores que en 1705 constaba de 200 vecinos o 890 personas, "sin contar los niños de leche ${ }^{\prime \prime}{ }^{8} \dot{\partial}^{\text {es }}$ posible emprender un estudio sobre el papel de las mujeres en el conflicto si, como ocurre en otros muchos casos, apenas existe rastro documental? Partimos de una dificultad añadida: la escasez de estudios sobre las comunidades campesinas en ese período. ${ }^{9}$ Como nos recuerda Pérez Aparicio son aún muchos los interrogantes que se derivan de la desaparición de la documentación y falta de estudios locales. ${ }^{10}$ Es cierto que la historiografía reciente ha subrayado el protagonismo femenino en la guerra de Sucesión, particularmente durante los asedios. ${ }^{11} \mathrm{Sin}$ embargo, la mayor parte de las noticias de las que disponemos pertenecen a los lugares más poblados, sobre todo en el muy documentado caso de Barcelona. ${ }^{12}$ Por otro lado, aunque abundan las pruebas del arrojo femenino en las localidades rurales sitiadas del resto de la Corona de Aragón y también en Castilla, no se conoce en profundidad la dinámica social cotidiana; menos aún el papel específico que jugaron las mujeres durante el conflicto sucesorio. Por ese motivo hemos tratado de indagar sobre el particular en el caso de Peníscola, que fue objeto de un bloqueo de 17 meses por tropas austracistas y un frustrado asedio, desarrollados

8 Testimonio de Sancho de Echeverría, designado comandante de la defensa de la plaza en octubre de 1705. ECHEVERRÍA, Sancho de (1705-1707), Diario de las operaciones militares exequtadas en la defensa de la plaza de Peñíscola en el Reino de Valencia, en Yale University Library, The Yale University Collection of Latin American Manuscripts. The Spain Collection, part 3, unit 1, reel 1, HM 249, s.f. El título del diario fue sobrescrito por el sobrino-nieto de Sancho de Echeverría, don Mariano de Echeverría y Veytia, al encontrarlo entre los papeles de su abuelo, que había emigrado a Puebla de los Ángeles (México). La transcripción en HERNÁNDEZ, Javier (2018), "Dos nuevas fuentes para el estudio de la Guerra de Sucesión en el Reino de Valencia", Boletín del Centro de Estudios del Maestrazgo, vol. 99, Benicarló, p. 56.

9 BORREGUERO, Cristina, (2003), "Imagen y propaganda de guerra en el conflicto sucesorio (1700-1713)", Manuscrits, vol. 21, p. 101.

10 PÉREZ APARICIO, Carmen (2008), Canvi dinàstic y guerra de successió. La fi del Regne de València, Tres i Quatre, València, vol. I, p. 166

11 FERNÁNDEZ, Elena (2011), "Historia y memoria de las mujeres asediadas", Cuestiones de Género: de la igualdad y la diferencia, vol. 6, pp. 35-50.

12 NASH, Mary (2000), "Género, identidad urbana y participación ciudadana: en torno al once de septiembre", Historia Contemporánea, vol. 21, pp. 315-331; MARTí, Maria A. (2006), "Les barcelonines durant el setge", en ALCOBERRO, Agustí, Catalunya durant la Guerra de Successió (II). La guerra dels catalans (1713-1714), Ara Llibres, Badalona, pp. 132-139; ALABRUS, Rosa M. (2010), "La opinión sobre las mujeres austracistas y el imaginario religioso en los sitios de 1706 y 1713-1714", Cuadernos de Historia Moderna, vol. 35, pp. 15-34; y ALABRUS, Rosa M. (2010), "Les dones austracistes i la Guerra de Successió", Pedralbes, vol. 30, pp. 245-266. 
en medio de una permanente guerra publicística. ${ }^{13}$ Esta "industria" de la literatura polémica, como la ha calificado Ettinghaussen, ${ }^{14}$ fue inherente a la estrategia de comunicación del poder en la edad moderna, desarrollada con profusión durante la guerra de Sucesión española. ${ }^{15}$ En la medida en que nos lo permitan las fuentes, el propósito de estas páginas es interpretar el papel que jugó la población femenina, también desde el punto de vista de la publicística, en la única plaza valenciana que durante toda la guerra permaneció fiel a Felipe $\mathrm{V}$, y si esta singularidad pudo deberse en algún sentido a su posicionamiento frente a la disyuntiva dinástica.

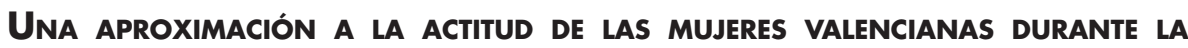 Guerra de Sucesión}

Como se ha adelantado en líneas anteriores los trabajos dedicados a la mujer en la guerra de Sucesión han revelado su implicación en tareas que la asignación tradicional de los roles de género reservaba a los hombres. Mary Nash comprobó en una primera investigación sobre el fenómeno la decisiva participación de las barcelonesas en la revuelta de septiembre de 1705 y durante los asedios de 1706 (en el que prometieron morir por su rey Carlos) ${ }^{16}$ y 1713-1714. De la polivalencia de su compromiso cabe destacar que tomaron las armas, espiaron al enemigo, incitaron a la pelea, alentaron la resistencia en las murallas, asistieron a los heridos, suministraron víveres, formaron parte del simbolismo bélico y su heroicidad fue celebrada por la publicística. ${ }^{17}$ Estudios posteriores como los de Martí

13 HERNÁNDEZ, Javier (2019), Guerras paralelas. Propaganda borbónica y austracista en Peñíscola (1700-1716), Diputación de Castellón, Castelló de la Plana.

14 ETTINGHAUSSEN, Henry (2005), "Informació, comunicació i poder a l’Espanya del segle XVII", Manuscrits, vol. 23, p. 45-58.

15 Sobre la publicística en la guerra de Sucesión véase PÉREZ, Ma Teresa (1966), La publicística española en la guerra de Sucesión, CSIC, Madrid; LÓPEZ-CORDÓN, Ma Victoria, (2007), "Defender a un rey, convencer a Europa: razones e imágenes de la propaganda castellana durante la contienda sucesoria", en GARCÍA, Francisco (coord.), La Guerra de Sucesión en España y la batalla de Almansa. Europa en la encrucijada, Sílex, Madrid; GONZÁlEZ, David (2009), Propaganda e información en tiempos de guerra, España y América (1700-1714), Sílex, Madrid; y BORREGUERO, "Imagen y propaganda".

16 BACALLAR, Vicente (1725), Comentarios de la guerra de España, e historia de su rey Phelipe $V$ el Animoso, desde principio de su reynado, hasta la Paz General del año 1725, dividido en dos tomos, vol. I, Génova, p. 247.

17 NASH, "Género", pp. 324-327. 
Escayol demostraron además que su papel fue igualmente principal en actos piadosos, rogativas públicas y procesiones, ${ }^{18}$ ceremonias religiosas que contribuían a la cohesión social, al consenso sobre la necesidad de resistir y la ratificación de la legitimidad de la lucha. Rosa M. Alabrús presentó nuevos hallazgos al conocimiento de la larga serie de actividades femeninas desplegadas durante este período. La autora analizó la utilización de la figura femenina combativa y el simbolismo de las mujeres santas catalanas como santa Eulalia y la Virgen, convertidas en capitanas. ${ }^{19}$ Esta idea seguía una antigua tradición publicística de los Habsburgo germánicos y españoles, que cultivó la poderosa imagen de una joven madre protectora que lucha contra sus enemigos y la herejía, ${ }^{20}$ referentes que contribuían al "proselitismo a través de la devoción". ${ }^{21}$ Muy significativo es el ejemplo de la santa local Maria de Cervelló, canonizada en 1693, cuyo cadáver se expuso al público, entre quien se hallaba el archiduque, que al posar su mano sobre ella "inflamó el ánimo de los asistentes". ${ }^{22}$

La expresión mitológica del simbolismo bélico femenino tuvo igualmente su espacio. No fue casual que la reina Cristina de Brunswick Wolfenbüttel fuera obsequiada en Barcelona por 12 amazonas, ${ }^{23}$ inequívoca imagen de la mujer guerrera, utilizada con fines propagandísticos también en la plaza de Peníscola para fomentar la causa borbónica como se analiza al final de este trabajo. En un sentido similar se buscó el impacto emocional en las conciencias a través del concepto de maternidad. Esto es lo que ocurrió sobre todo en los últimos meses de la resistencia de Barcelona en 1714, cuando los austracistas se refirieron a la ciudad como "capital madre" a la que debía auxiliarse. Por otro lado, la fuerza persuasiva de la arenga femenina para fomentar la subversión fue atestiguada por los cronistas borbónicos, reticentes a reconocer el influjo de las mujeres en la resistencia austracista. La implicación femenina con la idea de lucha incondicional

18 MARTÍ, "Les barcelonines", pp. 134-135.

19 ALABRÚS, "La opinión", pp. 24-26.

20 BERMEJO, José Luis (1990), "Símbolos de la Monarquía Española y de sus componentes territoriales en época barroca", en IGLESIA, Aquilino (dir.), Centralismo y autonomismo en los siglos XVI y XVII, Universitat Autònoma de Barcelona, Barcelona, pp. 67-100.

21 MARTíNEZ, Alfredo (1969), Religiosidad hispana y sociedad borbónica, Facultad Teológica del Norte de España, Burgos, p. 72, cit. en SURÉDA, François (2004), Le Théâtre dans la societé valencienne du XVIIle siècle, Presses Universitaires de Perpignan, Perpiñán, p. 409.

22 CASTELLVÍ, Francisco de (1998), Narraciones históricas, Fundación Francisco Elías de Tejada, vol. II, Madrid, p. 514.

23 CASTELLVÍ, Narraciones, vol. II, p. 500. 
fue tal que se tradujo en delaciones, incluso contra maridos que habían cambiado de bando. ${ }^{24}$

La participación femenina se extendía a todas las clases sociales y a los asuntos tanto políticos como militares. El tratamiento del conflicto dinástico y las eventualidades de la guerra en la correspondencia de damas, princesas y reinas seguía el patrón femenino que se esperaba de una mujer aristocrática: loar la valentía de los soldados, presumir la intervención de la providencia, practicar la resignación ante la adversidad y mostrar el horror ante las cifras de muertos en batalla. Pero entre esas aflicciones se descubre asimismo una tupida red de mujeres cortesanas que constituyó uno de los mecanismos de influencia política de la época. ${ }^{25} \mathrm{El}$ cronista Belando recordaba el doble juego de las nobles de Saboya, que prestaban obediencia al príncipe Eugenio tanto en público como en privado para "estar en ambos partidos". ${ }^{26}$ En efecto, las mujeres intervenían diariamente en los más altos asuntos públicos, protagonizaban estrategias políticas e influían en las decisiones militares. Son conocidos los ejemplos de Marie Anne de la Trémoille, princesa de Ursinos, que lideraba de manera personalista uno de los dos partidos de la corte madrileña en colaboración con el embajador francés Amelot, cuyas maniobras para sabotear las campañas militares del duque de Orleans nos desvela Francesc de Castellví en sus Narraciones Históricas, quien a su vez comentó la influencia en esa misma corte de madame Maintenon, aliada del duque. ${ }^{27}$ Pero las mujeres no privilegiadas, objeto de este estudio, también fueron protagonistas. Las mujeres campesinas, como se verá, llegaron a implicarse en los acontecimientos hasta el punto de formar líneas de combate.

En las páginas anteriores hemos esbozado las principales líneas de la contribución historiográfica al reconocimiento del papel femenino en la guerra de Sucesión, que se ha ocupado sobre todo del caso de Barcelona. ¿Qué ocurrió en el Reino de Valencia, en el que la dimensión de los combates y asedios alcanzó cotas realmente dramáticas en muchos casos? ¿̇ Hasta qué punto las mujeres valencianas se involucraron en los choques de las tropas, formaron parte del victimario y padecieron la represión? ¿Q Qué sabemos

24 ALABRÚS, "Les dones austracistes", pp. 249-263.

25 PÉREZ, Ma de los Ángeles (2007), "La batalla de Almansa en palabras de mujeres", en GARCÍA, Francisco (coord.), La guerra de Sucesión en España y la batalla de Almansa. Europa en la encrucijada, Sílex, Madrid, p. 531.

26 BELANDO, Nicolás de Jesús, frey (1740), Historia civil de España, sucesos de la guerra y tratados de paz, desde el año de mil setecientos hasta el de mil setecientos y treinta y tres, t. II, Madrid, p. 46.

27 CASTELlVí, Narraciones, vol. II, pp. 85, 336, 475 y 523. 
de los municipios y sociedades del mundo rural en ese contexto? Podemos adelantarlo ya, de la información que se encuentra en las páginas de los cronistas se desprende que las mujeres valencianas no se recluyeron en su domesticidad, aunque cronistas y comandantes se refiriesen a ellas mediante expresiones propias de la función social de género que nunca dejó de acompañarlas, como en los siguientes ejemplos. En la creencia de que al sexo femenino le es consustancial un pretendido carácter bondadoso López de Mendoza y Pons resaltó que las mujeres de Zaragoza se olvidaron de él en 1705 al enfrentarse al virrey y las tropas del mariscal Tessé. ${ }^{28}$ Las mujeres casi siempre son presentadas en los textos de la contienda acompañadas de sus hijos, como durante el motín antifrancés que se desató en Valencia al inicio de la sublevación. ${ }^{29}$ El conde de las Torres, general borbónico, escribió que había salvado por compasión a las "mujeres con sus niños" en el incendio de Vila-real, ${ }^{30}$ del que se conserva un relato estremecedor de una de las monjas dominicas del convento local, que describió el pánico sufrido por "mujeres y niños". ${ }^{31}$ El cronista proaustracista Francesc de Castellví aludió a que el destierro en 1710 de las mujeres partidarias del archiduque comprendió "al débil mujeril sexo", 32 fragilidad, más el llanto, que también atribuía al sexo femenino el cronista proborbónico Miñana. ${ }^{33}$ Y aunque suponía un claro testimonio de su valor, Castellví se hizo eco a su vez de la resistencia de las mujeres en la población alicantina de Planes con la siguiente expresión: "excedieron los límites de su sexo". ${ }^{34}$ Por tanto, los cronistas registraron episodios heroicos entre las mujeres valencianas, al mismo tiempo que les atribuían una congénita naturaleza poco apta para la guerra. Para valorar su papel analizaremos a continuación su determinación batalladora en los asedios de las poblaciones valencianas.

En principio debe advertirse que en la ciudad de Valencia no se reprodujeron las situaciones extremas propias de una ciudad sitiada, como sí ocurrió en Barcelona en tres ocasiones, lo que condicionó el carácter y cantidad

28 LÓPEZ DE MENDOZA Y PONS, Agustín (1882), Historia de las guerras civiles de España desde la muerte del señor Carlos II, que sucedió en $1^{\circ}$ de noviembre de 1700 distribuida en ocho libros por los mismos años regulados hasta el año de 1708, t. IV, Zaragoza, 1882, p. 258.

29 PÉREZ APARICIO, Canvi dinàstic, vol. II, p. 302.

30 PÉREZ APARICIO, Canvi dinàstic, vol. II, p. 363.

31 PÉREZ APARICIO, Canvi dinàstic, vol. II, p. 356.

32 CASTELLVÍ, Narraciones, vol. II, p. 477.

33 PÉREZ i DURÁ, F. Jordi y ESTELLÉS i GONZÁLEZ, José Mª (eds.) (1985) , José Manuel Miñana. La Guerra de Sucesión en Valencia, Alfons el Magnànim, Valencia, pp. 134 y 211.

34 CASTELLVÍ, Narraciones, vol. II, pp. 192 y 210. 
de noticias que sobre el esfuerzo femenino durante la guerra encontramos en la ciudad del Turia. Las tropas de Basset penetraron sin oposición en Valencia en diciembre de 1705 y al mes siguiente el ejército borbónico fracasó en su propósito de sitiarla, renunciando incluso a la organización de un bloqueo debido a las enormes dificultades de la operación. ${ }^{35}$ En este punto Francesc de Castellví enjuició la situación militar de forma errónea al afirmar que la ciudad del Turia quedó, desde luego, bloqueada en enero de $1706 .{ }^{36}$ Año y medio más tarde, tras la batalla de Almansa, los acontecimientos se precipitaron con tal rapidez que no fue necesario ni siquiera bloquear la ciudad, pues capituló el 8 de mayo de 1707. Que Valencia escapara de un cerco formal no significa, desde luego, que el desarrollo de la guerra y la cercanía de las tropas borbónicas no se vivieran con gran turbación o que no se desataran algaradas multitudinarias en las que estuvieron presentes las mujeres. Además, contribuyeron decisivamente en los actos públicos civiles y religiosos a promover la causa del archiduque.

Las anotaciones de un testigo de los acontecimientos, el dietarista Ortí i Major, nos remiten a la implicación femenina en la ciudad de Valencia. Intervinieron en las usuales mediaciones para resolver conflictos y la liberación de presos ${ }^{37}$ y en las acciones de protesta y reivindicación, como durante los disturbios desatados el 28 de diciembre de 1705, cuando una multitud persiguió a los franceses afincados en la ciudad. ${ }^{38}$ Pero su protagonismo fue mucho más allá. Denunciaron las atrocidades cometidas por las tropas borbónicas, contra las que se sublevaron, protestas que se extendieron en toda la región contra las contribuciones para mantener el ejército, al igual que había ocurrido en Lleida y Zaragoza. ${ }^{39}$ Acompañaron a los hombres en las recurrentes demostraciones populares de júbilo, como en la dedicatoria de "coplas laudatorias" al archiduque Carlos durante su apoteósico recibimiento el 30 de septiembre de $1706 .{ }^{40} \mathrm{Y}$ desde el punto de vista simbólico la imagen de protectoras mujeres santas fue evocada continuamente en las ceremonias públicas. Al igual que en el caso catalán en Valencia

35 PÉREZ APARICIO, Canvi dinàstic, vol. II, pp. 236-240 y 595.

36 Castellví afirma que Valencia fue bloqueada por el conde de las Torres y el duque de Arcos con 5300 tropas y 8 cañones, fuerzas insuficientes para tamaña empresa. Vid. CASTELLVí, Narraciones, vol. II, p. 39.

37 ESCARTí, Vicent Josep (2007), El Diario (1700-1715) de Josep Vicent Ortí i Major. Estudio y edición, Bancaixa, Valencia, p. 227.

38 ESCARTÍ, El Diario, n. 160, p. 95.

39 ALABRÚS, "Les dones austracistes", pp. 255-256.

40 PÉREZ APARICIO, Canvi dinàstic, vol. II, p. 514. 
fue recurrente la utilización por los austracistas de la devoción local a la Virgen de los Desamparados, a quien el archiduque visitó frecuentemente en su capilla durante el otoño de $1706 .{ }^{41}$ Esta estrategia simbólico-religiosa fue meticulosamente desarrollada por el comandante de la defensa de Peníscola para recabar igualmente el consenso de la comunidad local como se verá más adelante. Santa Ana fue saludada en Valencia el día 26 de julio de 1706 con salvas de artillería, como homenaje a la reina de Inglaterra, ${ }^{42}$ de donde provenía la mayor parte de los recursos monetarios para sostener la causa de los Habsburgo. La carga simbólica de estos actos devocionales alcanzó su cénit en una de las etapas de la guerra más comprometidas para los intereses austracistas. Desde octubre de 1706 las armas borbónicas habían comenzado a ganar posiciones en el sur del reino, amenazando la capital. El gobierno del archiduque organizó entonces un significativo acto de fervor mariano con la pretensión de redoblar la cohesión social. El 8 de diciembre, con la asistencia del archiduque, los Estamentos juraron defender en la capilla de la Virgen de los Desamparados la pureza de la inmaculada concepción. ${ }^{43}$

La respuesta de la mujer valenciana a las situaciones más peligrosas distó mucho de ser pasiva. Comprendió la arenga y el auxilio a las tropas y no faltaron ocasiones en las que ocuparon la primera línea de fuego para frenar a los sitiadores. Fueron cientos las mujeres campesinas que se unieron a las tropas de Basset en su avance hacia Valencia en diciembre de 1705.44 Alrededor de 600 mujeres fueron las que participaron en la defensa del baluarte alicantino de San Nicolás en el verano de $1706^{45}$ y decenas trabajaron en los muros de Xàtiva. ${ }^{46}$ En otras latitudes del Reino lucharon cuerpo a cuerpo cuando las circunstancias lo exigieron. Así sucedió en Benassal, Sant Mateu, Vila-real, Xàtiva, Planes, Ontinyent, Alzira, Dénia, Alacant, entre otras que padecieron asedios. También en Peníscola como se verá. En Sant Mateu, la primera población del norte valenciano que padeció un asedio, según refirió el gramático proaustracista Pere

41 PÉREZ APARICIO, Canvi dinàstic, vol. II, p. 193.

42 PÉREZ APARICIO, Canvi dinàstic, vol. II, p. 153.

43 Forma del juramento que en la capilla de Nuestra Señora de los Desamparados hizieron los eletos de los tres Estamentos, el día ocho de deziembre 1706, de defender la pureza de María en su Concepción Inmaculada. ESCARTí, El Diario, pp. 200-202.

44 PÉREZ DURÁ y ESTELLÉS i GONZÁLEZ, (1985), José Manuel Miñana. La Guerra de Sucesión en Valencia, p. 56.

45 ESCARTí, El Diario, p. 332.

46 CASTELLVÍ, Narraciones, vol. II, p. 363. 
Vincent Sabata los hombres lucharon enardecidos por la "fortaleza y animosidad de las mugeres", resistiendo con denuedo en enero de 1706 a las tropas del conde de las Torres, quien hubo de levantar el sitio. ${ }^{47}$ López de Mendoza, conde de Robres, relata en su Historia que esas mujeres lucharon en tejados y ventanas, participando del "furor del soldado". ${ }^{48}$ En Planes el arrojo femenino insufló valor a los sitiados por los borbónicos del conde de Chardy. ${ }^{49}$ Las mujeres combatieron también en primera línea durante los encarnizados asedios borbónicos de Vila-real, arrojando "piedras, aceite caliente y maderos" y Xàtiva, donde decenas de mujeres murieron bajo las descargas de los fusiles en mayo de 1707.50 Al parecer fue una mujer la que durante el asalto acabó con la vida del conde de Rosel tras arrojarle una piedra desde una ventana, aunque Miñana lo atribuyese a una muestra de "varonil atrevimiento". ${ }^{51}$ Estas pruebas de determinación se reprodujeron durante los ataques austracistas a Benassal, donde una de las defensoras perdió la vida de un disparo, ${ }^{52}$ así como en Morella, cuando arrojadas mujeres lanzaron piedras desde las murallas a las tropas del archiduque durante el sitio de octubre de $1710 . .^{53}$

Si las mujeres habían sido partícipes de todos y cada uno de los movimientos comunitarios de protesta y de numerosas acciones militares tampoco faltaron en los episodios de represión y muertes colaterales. Al igual que los hombres, forman parte del victimario del conflicto sucesorio. Los cronistas refieren abundante información sobre episodios trágicos en los que las mujeres de toda condición social sufrieron las mismas consecuencias que los hombres a los que alcanzó la represión. Alrededor de 60 damas de Valencia emprendieron el exilio por haber seguido junto a sus maridos el par-

47 SABATA, Pere Vicent (1706), Diaria y verídica relación de lo sucedido en el assedio de la villa y plaza de San Matheo, cabeza del Maestrado Viejo de Montesa, en el reino de Montesa, sitiada por las armas del señor Ludovico XIV, rey de Francia, en el año 1649; en la rendición de dicha plaza por las armas del señor don Carlos Tercero, rey de España, en el año 1705, y en su gloriosa defensa en la tercera vez que estuvo sitiada por las armas del Sereníssimo Señor Duque de Anjou en los años de 1705 y 1706, en QUEROL, Enric (2015), La presa de Sant Mateu del Maestrat pels anglesos a la Guerra de Successió, Onada, Benicarló, p. 63.

48 LÓPEZ DE MENDOZA, Historia de las guerras civiles, t. IV, p. 269.

49 CASTELlVÍ, Narraciones, vol. II, p.369, 374.

50 CASTELLVÍ, Narraciones, vol. II, pp. 57, 175, 264 y 364.

51 PÉREZ DURÁ y ESTELLÉS i GONZÁLEZ, (1985), José Manuel Miñana. La Guerra de Sucesión en Valencia, p. 78.

52 PÉREZ DURÁ y ESTELLÉS i GONZÁLEZ, (1985), José Manuel Miñana. La Guerra de Sucesión en Valencia, p. 220.

53 ESCARTí, El Diario, p. 298. 
tido austríaco. ${ }^{54} \mathrm{El}$ despótico general Basset se prodigó en azotar a mujeres sospechosas durante su mandato en la capital valenciana, e incurrió en los mismos desmanes en Xàtiva, uno de los motivos de su encarcelamiento, según el filoborbónico Miñana. ${ }^{55}$ Padecieron los estragos de asaltos encarnizados como el que dirigió el general Asfeld en noviembre de 1707 para rendir Dénia. ${ }^{56}$ Las tropas del conde de las Torres no perdonaron "edad ni sexo" tras el saqueo de Vila-real, ${ }^{57}$ donde según Bacallar pocas escaparon de la muerte; ${ }^{58}$ unos hechos dramáticos que vivieron seguramente las mujeres de Ontinyent pese a que Miñana no lo especificase. ${ }^{59}$ En Peníscola, las mujeres padecieron los rigores del bloqueo de la fortaleza junto al resto de la comunidad local pero examinemos ahora qué podemos saber de su significación en el desarrollo del conflicto al interpretar las fuentes conservadas.

\section{Actitud de las mujeres en peníscola frente al bloqueo de la plaza}

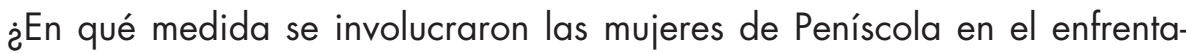
miento armado que se avecinaba una vez se estableció el cerco a la plaza el 14 de diciembre de 1705? Una de las primeras decisiones que tomó el nuevo comandante designado por Felipe $\mathrm{V}$ para defender la fortaleza, el guardia real vasco don Sancho de Echeverría (1674-1716), ${ }^{60}$ fue reclutar a las mujeres para labores logísticas mientras los hombres en edad de combatir fueron distribuidos en dos compañías armadas. Como la plaza carecía de frascos para la pólvora y balas Echeverría encargó a las mujeres fabricar bolsas para guardar munición. Dicha actividad no solo se había desarrollado para auxiliar a los soldados, sino que se esperaba que la dis-

54 PÉREZ DURÁ y ESTELLÉS i GONZÁLEZ, (1985), José Manuel Miñana. La Guerra de Sucesión en Valencia, p. 262.

55 PÉREZ DURÁ y ESTELLÉS i GONZÁLEZ, (1985), José Manuel Miñana. La Guerra de Sucesión en Valencia, pp. 70, 94 y 132.

56 PÉREZ DURÁ y ESTELLÉS i GONZÁLEZ, (1985), José Manuel Miñana. La Guerra de Sucesión en Valencia, p. 255.

57 CASTELLVÍ, Narraciones, vol. II, pp. 41.

58 BACALLAR, Comentarios, t. I, p. 310.

59 PÉREZ DURÁ y ESTELLÉS i GONZÁLEZ, (1985), José Manuel Miñana. La Guerra de Sucesión en Valencia, p. 91.

60 Una biografía sucinta en la web de la Real Academia de la Historia [http://dbe.rah.es/biografias/136851/sancho-de-echeverria-y-orcolaga]. Más extensa en HERNÁNDEZ, Guerras paralelas, pp. 38-45. 
tracción les ayudara a escapar del tedio o la turbación. Lo contrario podría contribuir al pesimismo, el desaliento y aún peor, a una conspiración que el conde de Cifuentes, comandante general aliado en las fronteras de la Corona de Aragón, se había propuesto fomentar por diferentes vías. En ocasiones Echeverría se sirvió de las danzas y la música para entretener a la población. ${ }^{61}$ Vigilar conversaciones y opiniones contrarias, especialmente tras un intento frustrado por descabalgarle del mando, se convirtió en rutina. Echevarría se las arregló posteriormente para atraerse la simpatía de los vecinos mostrándose dadivoso especialmente con las mujeres, a las que, en circunstancias comprometidas repartió "un refresco", consciente de que ellas agradecerían un gesto que suavizaría los rigores del racionamiento. Pero el vasco no sólo buscaba apaciguar los ánimos sino sobre todo que las mujeres determinaran en su favor la opinión de los hombres. Según las palabras de Echeverría el refresco hizo "más ynpresión en las mujeres, como tan madres de sus hijos", a las que calificaba de "despóticas en las voluntades de sus maridos". Es un testimonio que evidencia la obsesión del guardia real por mantener a raya la voluntad de los hombres a través de las mujeres, y evitar que el malestar femenino sugestionara negativamente la voluntad de toda la comunidad.

Resulta evidente que Echeverría temía los efectos del estado de ánimo y la transgresión femeninos sobre sus directrices. Esa preocupación tenía consecuencias incluso en el sentido de sus decisiones militares. Él mismo confesó que al ser consciente de "las malas consequencias del clamor de mujeres e hijos" en una ocasión cabalgó escoltado por un grupo de soldados de la guarnición para rescatar algunos vecinos que se habían quedado rezagados en una salida y estaban siendo hostigados por los migueletes. En otro momento alteró sus planes al no ser bien recibida entre las mujeres la idea de reclutar a unos marineros, a quienes había convencido para remar durante la noche en una de las múltiples salidas en barca que promovió para conseguir vituallas: "hubo de prevalecer el dictamen en ellos por no disgustarles, ni yo me empeñé sobre el caso por la fuerza que tenía".

Echeverría trató por todos los medios de escrutar la voluntad de las mujeres e incluso adelantarse a sus posibles reacciones. Por ese motivo describió el preludio de las acciones militares que desarrollaba fuera de las murallas como un momento de significado desasosiego, provocado no tanto por la incertidumbre de la batalla como por la inquietante perspectiva que podría 
generar en el estado de ánimo de las aldeanas la muerte de sus familiares. Le sobrecogía la idea (pensando en el control de la plaza) de que las mujeres acusaran la pesadumbre: "Al tiempo de mi partida, mi principal cuidado fue evitar algún estrago, y con el alarido de mujeres y niños". El recelo aumentó durante los crudos meses del verano de 1706, período en el que las privaciones y carestía comenzaron a ser intolerables. Los soldados regulares compartían su desmoralización (algunos comenzaron a desertar) en conversaciones con las mujeres. Mostrándose de nuevo sensible a las consecuencias de la opinión femenina Echeverría acusó a esos soldados de provocar preocupantes "lamentos" en las mujeres.

Las mujeres de la villa interpretaban los acontecimientos desde un punto de vista religioso y organizaron actos devotos, imprescindibles para aglutinar la voluntad popular. Aunque sólo disponemos de una noticia a este respecto, es seguro que las mujeres locales actuaron, como en otros lugares, de intermediaras entre la patrona local y la población en diferentes ocasiones. Así se desprende de una espontánea reacción por iniciativa femenina tras la victoria de Echeverría en una batalla contra una de las fragatas de la armada del archiduque, con base en Vinaròs, lo que nos remite de nuevo a la influencia femenina en la regulación del consenso comunitario a través de la piedad. Poco antes las mujeres se habían dirigido de manera espontánea al ermitorio de la patrona local, de donde extrajeron la imagen de la Virgen de la Ermitana y la colocaron en el exterior para rogarle por el comandante de la plaza: "puesta en la roca le pedían me librase del riesgo con los demás". ${ }^{62}$

\section{Roles tradicionales e idealización de la mujer de Peníscola. Referentes MITOLÓGICOS Y CRISTIANOS}

\section{Modelos literarios y propagandísticos previos}

La evidencia sobre la significativa contribución de las mujeres al esfuerzo bélico durante la guerra de Sucesión contrasta con el paradigma oficial de su función social. Por esa razón resulta paradójico que la literatura polémica del período auspiciada por el poder conceda a la mujer los rasgos propios del género masculino. Pero la necesidad de persuadir a la sociedad en su conjunto durante un conflicto bélico internacional que además presentaba en España rasgos de confrontación civil así lo exigió. Era una 
guerra total que movilizó al conjunto de la población, sin cuya anuencia gobernar o vencer resulta imposible a largo plazo. En la publicística del período los roles de género se diluyeron en pos de una causa superior que necesitaba del consenso de toda la sociedad. En este sentido los heterodoxos roles femeninos que desplegaba el teatro y la poesía fueron la plataforma perfecta para movilizar ideológicamente a la mujer. Como consecuencia, las comedias se convirtieron en uno de los instrumentos más eficaces en la guerra propagandística que se libraba. Las primeras referencias relativas a comedias surgidas en España en el contexto de la guerra de Sucesión datan de 1703 y tuvieron como escenario Barcelona. ${ }^{63}$ Se trata de cuatro piezas que criticaban el abandono portugués del campo borbónico. Otras comedias representadas en Madrid y Valencia expusieron los argumentos de las dos dinastías, ridiculizaron al enemigo, denunciaron sus atrocidades y ensalzaron las gestas de los ejércitos propios. Las composiciones poéticas participaron del mismo programa propagandístico. ${ }^{64}$

¿Qué modelo femenino proponía la publicística en esas composiciones teatrales? La respuesta nos permite ubicar en su contexto propagandístico los personajes femeninos de la comedia sobre el asedio de Peníscola que se analiza más abajo. Lógicamente la comedia de asedios se sirve de la imagen que mejor podía encarnar a la mujer guerrera, que no cede ante la proximidad de la muerte, idealizada en algunos casos mediante el recurso a la heroína clásica, la amazona, evocada como se ha mencionado más arriba también en actos públicos. Aun sin abandonar completamente la tradicional adscripción de los roles de género, la publicística elevó a la mujer a las mismas cotas épicas que conquistaba el hombre a golpe de gestas al igual que en la comedia barroca. ${ }^{65}$ En la proborbónica pieza Las lavanderas de Caravanchel: Mari García y su nuera Isabel (1706 o 1707) a las protagonistas les parece que a Cataluña conviene "darle un jabón", 66 pero esa adscripción arquetípica de una de las más reconocibles funciones so-

63 VALL, Francesc Xavier (2015), "La guerra de Successió en el teatre i la poesia catalans de l'època", Manuscrits. Revista d'Història Moderna, vol. 33, p. 142.

64 VALL, "La guerra de Successió", pp. 139-145. Ortí i Major anotó en su diario que en el verano de 1706 se representaban comedias "todos los días". ESCARTí, El Diario, p. 165.

65 En la Comedia del çerco de Numancia Cervantes dramatizó los últimos momentos de las "tristes madres" al ver morir a sus hijos. La angustia materna también ocupó los versos calderonianos de El Sitio de Breda (1685) en el personaje de la esposa de Enrique de Nassau. [http://www.cervantesvirtual.com/obra-visor/el-cerco-de-numancia-0/html/] y [http://www. cervantesvirtual.com/obra/el-sitio-de-breda-0/].

66 ESCARTí, El Diario, p. 341. 
ciales que se les atribuía en la época era la excepción. Las comedias, como un instrumento más de la publicística de guerra, exaltaron su determinación en los combates, como en los Goigs de Carles Tercer, pieza que encomiaba el sacrificio femenino al atribuirles la defensa de los hogares, aunque esa misma distribución del espacio contenga un evidente sesgo de roles. ${ }^{67}$ Estos rasgos de la mujer pendenciera se reforzarán con el transcurso del siglo. Prefiguraban la imagen de las "mujeres fuertes" de las comedias de guerra españolas de finales del siglo XVIII, protagonizadas por bravuconas heroínas varoniles de todos los grupos sociales que perseguían la gloria en la batalla. ${ }^{68}$ Se trata ahora de analizar los roles y modelos femeninos utilizados en la comedia destinada en Peníscola a la movilización popular durante la guerra de Sucesión. ${ }^{69}$

\section{Las mujeres de Peníscola según la comedia del asedio}

Una vez levantado el bloqueo austracista de la fortaleza de Peníscola el 14 de mayo de 1707 Sancho de Echeverría compuso seguramente la pieza teatral anónima titulada Comedia famosa en que se representa el asedio o sitio de Peñíscola (c. 1707). ${ }^{70}$ Hacía poco tiempo que se había representado en Valencia y Barcelona una comedia proaustracista, Comedia famosa del sitio de Barcelona, y fuga del duque de Anjou, inspirada en el fracasado asedio borbónico de mayo de 1706, que contenía referencias a la obstinación femenina en la defensa de la ciudad, su participación en la distribución de vituallas y auxilio a los heridos, pese a que su aliento se considerase "varonil". ${ }^{71} \mathrm{El}$ autor de la comedia peniscolana se extendió

67 ALABRÚS, "Les dones austracistes", p. 248.

68 FERNÁNDEZ, Rosalía (2003), "La mujer guerrera en el teatro español de fines del siglo XVIII", Anuario de Estudios Filológicos, vol. 26, pp. 117-136.

69 Sobre su contenido y relación con la publicística del período véase HERNÁNDEZ, Javier (2019), "Versos para Felipe V: propaganda borbónica en Peñíscola durante la Guerra de Sucesión Española", Millars. Espai i Història, vol. 46, pp. 169-193.

70 Biblioteca Nacional, Manuscrito 14931. Véase PAZ, Antonio (1989), Catálogo de piezas de teatro que se conservan en el departamento de manuscritos de la Biblioteca Nacional, Biblioteca Nacional, t. 3, Madrid. Echeverría era aficionado a la poesía. La pieza revela un conocimiento de la plaza de Peñíscola y su entorno que solo un testigo de los acontecimientos pudo haberla redactado. Además se trata de una hagiografía del propio Echeverría. HERNÁNDEZ, Guerras paralelas, pp. 168-169.

71 RIBES, Josep (1706), Comedia famosa del sitio de Barcelona, y fuga del duque de Anjou, Biblioteca de Catalunya, 83-12-C-51/6, f. 25r. La atribución más fundada de la obra se encuentra en SURÉDA, Le Théâtre, p. 403. Un análisis en FOGUET, Francesc (2015), "Nòtul. les sobre "Comedia famosa del sitio de Barcelona y fuga del duque de Anjou, de Josep Ribes (1706)" [https://ddd.uab.cat/record/130654? $\mid \mathrm{n}=\mathrm{ca}]$. 
con más profundidad en la construcción publicística de la mujer, con la particularidad de que no se trataba de mujeres de una gran urbe sino de aldeanas dispuestas a morir por la causa de Felipe $V$, un tipo específico de comedia, por su extensión (3702 versos) y focalización rural, que no tiene parangón en la publicística de la guerra de Sucesión.

La intención de Sancho de Echeverría no era otra que la de fomentar la resistencia recurriendo también a la literatura política desplegada por los filipistas, eclipsada hasta el desenlace de la batalla de Almansa (25 de abril de 1707) por una larga cadena de victorias aliadas en España y el resto de Europa. Recogiendo el fruto de ese empuje y el del levantamiento del cerco en Peníscola tres semanas después, comenzaría seguramente la redacción de la obra. Su finalidad adoctrinadora consistía en mantener movilizada a la población local en una guerra que no había concluido y que no lo hará sino hasta ocho años después. En ese contexto iba a ser esencial promover el consenso social en la fortaleza y asegurar así las posiciones borbónicas en la frontera entre Valencia y Cataluña. Con tal fin Echeverría pretendió enardecer a los campesinos y fomentar específicamente el espíritu combativo de las aldeanas. Al hacerlo, indirectamente nos transmitía la importancia que concedió a las mujeres para reforzar su propio ascendiente, demostrándonos de paso que las mujeres no sólo influyeron en las conciencias de sus maridos e hijos sino en la orientación de las decisiones políticas del gobernador de la plaza, quien supo aprovechar hábilmente esa característica para sus propios fines al combinar en la pieza teatral tanto referencias al estereotipo tradicional de la mujer como a su convicción por combatir a los sitiadores.

Era doble el motivo de esa distinción de roles. El rol femenino tradicional, por un lado, ubicaba a los personajes en un contexto verosímil que el público pudiera identificar, rasgo ya conocido del teatro barroco. Por ese motivo los tres personajes femeninos de la comedia de Peníscola, DOÑA MargaritA (esposa del comandante general aliado Peterborough, MILORT PREterbURCH), Beatriz (amada del labrador CeliO) y Graciosa Dragona responden a prototipos sociales. MARGARITA pertenece a la alta nobleza inglesa, quien pondera con recurrencia el valor del gran conquistador inglés, tal y como se espera de ella. BeATRIZ, típicamente "hermosa", representa a la aldeana peniscolana idealizada que vela por su esforzado amado CELIO, personaje que se inspira en un labrador que efectivamente murió en una escaramuza. BeATRIZ y MARGarITA, siguiendo fielmente las pautas reconocibles de su relación con sus esposos sufren la adversidad y temen los peligros a los que se enfrentan estos, a los que saludan como valientes (v. 682 y v. 1032)..$^{72}$ 
La Graciosa Dragona es de baja condición social, en este caso una pobre moza, y forma pareja dramática con el insolente REGAÑ́́N, que se dirige a ella denigrándola, reproduciendo los peores prejuicios históricos sobre las mujeres. En sus imprecaciones no solo la tilda de "maldita moza fregona" y le reprocha su aspecto físico (la llama "pandorga" o gruesa) sino que la compara con una prostituta, la peste y el demonio. ${ }^{73}$ La función de esta pareja dramática es simplemente la de dotar de coherencia a la estructura y desarrollo de la pieza barroca.

Un primer uso publicístico de la concepción tradicional en torno a los roles masculinos y femeninos fue el que proporcionaba la simbología materna y paterna, recurso común promovido por las dos dinastías y los comandantes del ejército de ambos bandos en sus intentos por persuadir al enemigo. Fue prolífico en su empleo uno de los más destacados publicistas proborbónicos del conflicto, el obispo de Cartagena, quien se dirigía continuamente a sus fieles como a hijos. ${ }^{74}$ En el escenario de la pequeña península el conde de Cifuentes, que había visitado la plaza en su infancia, propuso a sus habitantes el mismo trato que un padre debía dispensar a sus hijos y hermanos, eso sí, siempre y cuando se rindiesen para evitar su ira. $^{75}$ Sancho de Echeverría no se quedó atrás en su estrategia de comunicación y no dejó de mostrarse ante sus gobernados, a quienes frecuentemente se refería como a sus "hijos", como un abnegado padre, aunque aplicase los procedimientos más expeditivos contra los disidentes. ${ }^{76}$ Entre otros momentos, fue crucial la apelación paternofilial que profirió durante el consejo general celebrado en la población el 10 de noviembre de 1706, cuando los defensores apenas eran ya capaces de sostener un día más la capacidad de resistencia ante la escasez de vituallas. ${ }^{77}$ Al elaborar la trama de

73 HERNÁNDEZ, Guerras paralelas, pp. 229-230.

74 Carta que el ilustrísimo señor don Luis Belluga, obispo de Cartagena, del Consejo de su Majestad, escribe a los fieles de su obispado, principalmente a la gente sencilla, previniéndoles del riesgo de dar crédito a una falsa doctrina y error que en conversaciones privadas, y hasta en el confesionario mismo en esta ciudad y algunos lugares de la diócesis se ha pretendido sembrar, en DÍAZ-PLAJA, Fernando (1986), Historia de España en sus documentos. Siglo XVIII, Cátedra, Madrid, p. 45.

75 Archivo Histórico Nacional, Estado, leg. 2902, s.f. HERNÁNDEZ, Guerras paralelas, p. 90.

76 Por ejemplo, cuando amenazó con ahorcar al gobierno local si se implicaba de nuevo en una conjura o al desterrar a sus adversarios junto al exgobernador. HERNÁNDEZ, Guerras paralelas, p. 106.

77 FEBRER, Juan José (2010), Peñíscola. Apuntes históricos. (Edición ortiginal de 1924), Diputación de Castellón, Castelló de la Plana, p.252. 
la Comedia famosa de Peníscola empleó igualmente ese vínculo familiar para atraer la voluntad de vecinos y autoridades locales. Es evidente la capacidad persuasiva de los lazos consanguíneos en un texto que aspiraba a reforzar la autoridad del comandante de la defensa y fomentar la lealtad, como si se tratara de la obediencia debida por los hijos a un padre. DoN SANCHO, protagonista de la pieza, trasunto del propio Echeverría, esgrime que la causa de Felipe V es "hija de Dios" (v. 611) y con el mismo sentido paternalista arenga a la comunidad: " ${ }^{E}$ Ea hijos, los fusiles / disparad todos a un tiempo!" (vv. 1540-1541). ${ }^{78}$

Las características intrínsecas a las de un valeroso soldado sirvieron a Echeverría como segundo recurso publicístico, que concedió circunstancialmente a las idealizadas aldeanas locales. Era consciente de la insustituible colaboración de las mujeres para recabar el consenso social y continuar la lucha. Sus versos evocan personajes femeninos que históricamente habían encarnado el espíritu más beligerante de la mujer en defensa de un pueblo en trance de ser vencido. La mitología grecorromana y el Antiguo Testamento suministraron al autor de la comedia los personajes adecuados para transmitir aquel estado de ánimo. Al referirse al motivo que perturbaba su pensamiento el labriego Cello invocó a "Venus" con flechas y aljaba (atributos que corresponden en realidad a Diana) para convencer a BEATRIZ de que ese estado de ánimo no era resultado del desamor. La situación del cerco y el escenario se comparan con las agresiones a los hebreos que recogen los textos bíblicos, y Peníscola se presenta como una suerte de refugio del pueblo elegido de la misma forma que lo fueron los israelitas. DoN SANCHO infiere que si Israel fue favorecida "por hacer de Dios la causa" (v. 3020) al igual le ocurrirá a Peníscola, aislada completamente en mitad de la Corona de Aragón. Se colige, por tanto, que el ahora flamante brigadier y gobernador de la plaza (ascendido a mariscal de campo en 1709) se presenta como una suerte de Moisés en quien recae la salvación de un peñón por cuya encomiable lealtad vela el cielo. En la relación que establece entre la providencia y Peníscola compara a la patrona local Virgen de la Ermitana, con dos personajes bíblicos femeninos que, en su defensa de Israel, habían encarnado históricamente la osadía de las mujeres en la guerra: Jael y Judit. La primera asesinó a Sísara, general cananeo, para salvar de su ejército a los israelitas. La segunda degolló al general babilónico Holofernes, a la que DON SANCHO asimila a la Virgen local, la "nueva Judit María". Al igual que Judit, la Virgen de la Ermitana es la "Señora" que "ha de vencer" como "gobernadora" de Peníscola (vv. 868-923)..$^{79}$

78 HERNÁNDEZ, Guerras paralelas, p. 240.

79 HERNÁNDEZ, Guerras paralelas, pp. 217-219 y p. 286. 
La intención era crear una aureola de invencibilidad a través de figuras femeninas poderosas y a la vez carismáticas que han pasado a la historia como salvadoras del pueblo oprimido que sustentaba la verdadera fe, la causa que por analogía los habitantes de Peníscola debían identificar con la suya propia en la defensa de Felipe $V$ frente al general Peterborough, el nuevo Holofernes.

El destino fatal de CELIO sirve en la obra para constatar que el coraje de los naturales puede igualar al de cualquier soldado regular, exhibiendo su muerte como prueba definitiva. En ese momento BEATRIZ expresa su dolor en una sucesión de estrofas que ratifican su amor abnegado, prometiendo "fielmente" mantener sus sentimientos con "dulce cadena". El autor recurre entonces a la mitología griega y la figura trágica de la Filomela ovidiana para evocar la tristeza inconsolable: "y tu muerte lloraré / yo cual otra Filomena" (vv. 2880-2881). Pero el autor no acota el papel de BEATRIZ a una mera intérprete de sentimientos trágicos, sino que la convierte en copartícipe del ardor campesino para reducir a los sitiadores. Como se ha adelantado más arriba, al escribir para ellas y sobre ellas el autor de la comedia reconoce su inexcusable implicación en la persuasión del conjunto de la comunidad local. Ellas opinaban y conferían con sus palabras y proceder legitimidad a las acciones del grupo, de manera que su inclinación partidista y actitudes no pueden desgajarse de cualquier intento por comprender la ideología moral de la multitud. Por ese motivo BEATRIZ, erigiéndose en intérprete y portavoz del resto de la comunidad femenina local, asegura a DON SANCHO que tomarán las armas con un ímpetu equiparable al de los hombres, incluso si estos faltaban a su deber. Al formular esa declaración de principios el autor de la comedia acudió de nuevo a la mitología como fuente alegórica de la mujer guerrera ideal, la amazona:

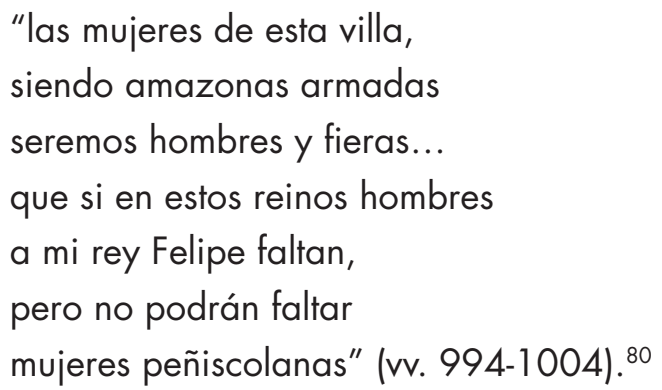




\section{La Virgen de la Ermitana como paradigma femenino para la guerra legítima y la movilización}

En líneas anteriores se ha hecho referencia a la recurrente utilización del culto mariano por la publicística en la guerra de Sucesión. La figura de la Virgen es el referente femenino preferido, pues su condición de madre de Dios le otorga un notorio poder de sugestión al proyectar cualidades que según el consenso social incumbían a la mejor de las madres: comprensión, mediación, protección y amparo. La publicística manipuló la fe y convirtió las particulares representaciones locales de la Virgen en partícipes partidistas del conflicto, intercediendo ante la providencia, obrando prodigios y decantando el desenlace de las batallas. Cuando en el norte del Reino la población de Sant Mateu resistía el asedio borbónico la versión proaustracista del choque contempló que la huida de las huestes borbónicas fue el colofón de un castigo divino por haber saqueado la ermita de Nuestra Señora de los Ángeles. El sacrilegio había provocado la "intercessión y poderosa mano de la Virgen" en favor de los sitiados. ${ }^{81}$ Esa misma mano prodigiosa es la que reclamó Felipe $V$ tras la batalla de Almansa con la esperanza de que "María Santíssima Protectora de España" interviniese en el campo de batalla "hasta la entera exterminación de los enemigos". ${ }^{82}$

En el contexto de Peníscola la Virgen de la Ermitana no es una excepción en esa misma faceta de protección e intervención mediante prodigios que le asigna la publicística de ambos bandos. Va a formar parte además del núcleo de la estrategia de control social y movilización que desplegó Sancho de Echeverría a lo largo del litigio sucesorio. El oficial real concedió una extraordinaria importancia a la ecuación que relacionaba Peníscola con la patrona local y Felipe $V$ con la voluntad divina. No se trataba solo de convencer a la población de que iba a ser auxiliada por la providencia sino de otorgar a la resistencia el carácter de legítima reacción frente al oponente porque contaba con su consentimiento. Bajo estas premisas Echeverría se afana en identificar la centenaria piedad que profesa la población a su patrona con la fidelidad a Felipe V. El resultado esperado consistía en comprometer a la comunidad local con una incondicional lealtad a la dinastía borbónica y, por consiguiente, asegurar la resistencia a ultranza. Ese es el propósito que persigue DON SANCHO al arengar a la población invocando a la patrona local y evocando la figura paternal que

81 QUEROL, La presa de Sant Mateu, p. 60.

82 GUILLAMÓN, F. Javier y MUÑOZ, J. David (2006), "La lealtad castellana en la Guerra de Sucesión. Movilización social y representación del poder en una sociedad en guerra", Revista de Historia Moderna, vol. 24, p. 527. 
él mismo encarnaría: "Ea hijos, que la Virgen / de la Hermitana da favor." (v. 2130 ). La superación del final del asedio inglés de marzo de 1706 probaría a su vez la connivencia divina: "cuan de nuestra parte Dios, / y su madre soberana / para darnos favor son" (vv. 2161-2163). ${ }^{83}$ Advirtamos que la figura trascendente que tiene el poder de intervenir milagrosamente es la "madre" de Dios, por eso es "soberana" y actúa efectivamente sobre los asuntos terrenales como "gobernadora".

Echeverría demostró una gran habilidad para inclinar la devoción popular a su favor, ya que al llegar a la plaza en octubre de 1705 era un completo desconocido, y las circunstancias militares que sobrevendrán en el conjunto del Reino tampoco contribuyeron a que fuera fácil que los naturales aceptaran su voluntad sin más. Lo demuestra el hecho de que tratase de congraciarse con los peniscolanos desde los primeros días. Tras haberse formado el cerco delante de la fortaleza Echeverría concibió una temeraria expedición militar, cuyo pío propósito era rescatar del convento de trinitarios (que se encontraba extramuros) unas figuras de Cristo y la Virgen de Gracia con el Niño. No cabe duda de que el éxito de la operación le granjeó las primeras simpatías entre la población. Que Echeverría buscase la complicidad de los naturales mediante acciones que contemplasen la devoción local no significa que la religión y el mensaje de que Dios favorecía la causa de Peníscola fueran exclusivamente armas ideológicas oportunistas. Eso se desprende de las reiteradas alusiones que pueden leerse en el diario de Echeverría al favor que le otorgaba la Virgen, a la que llamaba "Madre Santísima" ${ }^{84}$ En una carta a José de Grimaldo, secretario de guerra de Felipe $V$, el oficial vasco se mostró convencido de que el airoso encadenamiento de choques con el enemigo evidenciaba que la mano de Dios intervenía a través de la patrona local. La batalla librada contra la fragata la atribuyó a un "prodigio", que interpretaba como "evidentes señales de que Dios quiere guardarme para ser, aunque tan dévil, ynstrumento para preservar a esta peña". ${ }^{85}$ En su diario anotó de manera más personal que el desenlace debía atribuirse realmente a la asistencia de la Virgen de la Ermitana, a quien le mostró su gratitud con la celebración de una misa solemne en la parroquial, que igualmente contribuía al adoctrinamiento y propaganda. No cabe duda de que la ceremonia, que debió congregar a la mayor parte de la población, contó con la participación femenina en un momento de la contienda que supuso un aldabonazo para la estrategia de control social emprendida por Echeverría.

83 HERNÁNDEZ, Guerras paralelas, p. 259-260.

84 HERNÁNDEZ, "Dos nuevas fuentes", pp. 74 y 77.

85 HERNÁNDEZ, Guerras paralelas, p. 96. 
La relación del gobernador con la Virgen será constante hasta su inesperado fallecimiento en 1716, pues había patrocinado la construcción de un templo bajo su advocación para la exaltación de la dinastía borbónica, cuya decoración pétrea de la fachada es todo un panel narrativo del asedio a la plaza y protagonista de los acontecimientos. La memoria del asedio y el sagrado auxilio de la Ermitana contribuyeron además a la perpetua exaltación de los hechos del oficial real vasco. La misión política de la devoción a la Virgen local no terminó, desde luego, con los tratados de Utrecht-Rastatt ni con la muerte de Echeverría. Las necesidades políticas de la nueva dinastía, que iniciaba su gobierno en España con una paralela obra de legitimación, más la importancia concedida a fortalezas como la de Peníscola para la custodia de las fronteras de la monarquía, prolongaron en el tiempo la representación de la imagen de la Ermitana en estampas, grabados, patentes de sanidad, licencias de publicación e incluso en la letra local de los gozos que todavía hoy se canta. Evoca el dominio austracista de los territorios peninsulares de la Corona de Aragón a excepción de las plazas de Rosas y Peníscola y el auxilio de la Virgen: "De Rosas a Cartagena / todos los pueblos del mar / vinieron a peligrar, / rindiéndose a mano ajena; / Peñíscola fue Azucena / que por Vos se libró ufana". ${ }^{86}$

\section{Conclusiones}

En este artículo hemos tratado de demostrar, pese a las limitaciones que imponen las fuentes, que las campesinas de Peníscola merecen un lugar en la historia de la guerra por un doble motivo: su contribución a la publicística borbónica del período de la guerra de Sucesión y el papel que ejercieron en la comunidad local durante el desarrollo del bloqueo y asedio de la plaza, tanto para cohesionar a los vecinos como participando en tareas de auxilio a los soldados. El estudio supone también un llamamiento a la realización de otros estudios locales que permitan profundizar en el conocimiento de las campesinas en este período.

La mujer de Peníscola fue idealizada en una pieza de teatro escrita seguramente por Sancho de Echeverría y Orcolaga, guardia real de origen vasco, comandante de la defensa y premiado con el título de mariscal de campo,

86 Sobre la perpetuación de la legitimidad borbónica en Peníscola a través de la construcción de la memoria, arte y religión en HERNÁNDEZ, Guerras paralelas, pp. 154-160. 
para construir un relato borbónico de fidelidad a Felipe $\mathrm{V}$ y fomentar la lucha. Esta comedia no sólo recoge el arquetipo de la abnegada enamorada a través del personaje de BEATRIZ, sino que esta es ejemplo de compromiso al espolear a su amado para que luche en favor de Felipe $V$, a la vez que manifiesta la voluntad de todas las mujeres de la población por luchar como amazonas. En auxilio de la movilización popular el autor recurre en la obra a personajes de la mitología clásica y del Antiguo Testamento, tanto masculinos como femeninos, en este último caso a Venus (por Diana), Jael y Judit.

Cabe resaltar el protagonismo que cobró tanto en la Comedia famosa como en los hechos que se desarrollaron en Peníscola la patrona local, Virgen de la Ermitana, modelo cristiano de perfección femenina, cuya devoción fue utilizada con habilidad por Echeverría, en pos del consenso de la comunidad en favor de Felipe V. Esa voluntad demuestra la constante preocupación del oficial real frente a la opinión y reacción de las mujeres a los eventos que se van sucediendo. Echeverría estaba convencido de su determinante influencia sobre el resto de vecinos. Al dirigir su atención hacia las aldeanas desplegó toda una serie de gestos amables para aplacar su malestar, suministrando más alimentos $u$ organizando eventos de danza y música. También evitó acciones arriesgadas para no provocar el desaliento entre ellas. Echeverría las temía, y al temerlas nos ha legado en su diario y obra teatral la relevancia que él mismo otorgó a la mujer rural como pieza clave para comprender el posicionamiento de una pequeña comunidad campesina en la guerra moderna, su labor para mantener unidos los lazos intercomunitarios y los consensos vecinales e incluso para condicionar las decisiones militares. En definitiva, la resistencia y victoria final de Peníscola en mayo de 1707 no puede disociarse del crucial concurso de sus mujeres, sin las cuales Echeverría no podría haber concitado el consenso social imprescindible para mantener de manera sostenida la resistencia de una población sitiada y sometida durante más de un año al racionamiento, las enfermedades y la guerra viva. 



\title{
AGUSTINA DE ARAGÓN IN CAIRO. WOMEN WARRIORS AND NATIONAL HEROES IN GLOBAL HISTORY*
}

\author{
AGUSTINA DE ARAGÓN EN EL CAIRO. MUJERES \\ GUERRERAS Y HÉROES NACIONALES EN LA \\ HISTORIA GLOBAL
}

\author{
Adrian Shubert \\ York University
}

\begin{abstract}
This article uses recent findings from studies of women warrior and national heroes as an enduring and complex transnational and global phenomenon to re-examine the figure of the iconic Spanish example of such a figure: Agustina de Aragón. Specifically, it explores how and why she, and not others, was turned into a national hero, how Spaniards managed the subversion of gender roles that a woman warrior represented, the effect of her long outliving the events of 1808 that made her famous, and the extent to and ways in which her figure as a woman warrior circulated beyond Spain.
\end{abstract}

Keywords: Warriors, heroes, women, gender, global history

\section{RESUMEN}

Este texto se construye a partir de estudios recientes centrados en las mujeres guerreras y los héroes y heroínas nacionales como un fenómeno transnacional y global duradero y complejo con el fin de reexaminar la figura del icónico ejemplo español de Agustina de Aragón. De forma concreta se explora cómo y por qué ella, y no otras, se convirtió en una heroína nacional, cómo los españoles lograron la subversión de los roles de género que representaba una mujer guerrera, el impacto de su prolongada supervivencia a los acontecimientos de 1808 que la hicieron famosa y el alcance y las formas en que su figura como mujer guerrera circularía más allá de la propia España.

Palabras clave: Guerreras, heroinas, mujeres, género, historia global

* This is an expanded and reelaborated version of an earlier article published as "Women Warriors and National Heroes: Agustina de Aragón and Her Indian Sisters" in the Journal of World History, June 2012, pp. 279-313. 


\section{RESUM \\ AGUSTINA D'ARAGÓ A EL CAIRE. DONES GUERRERES Y HEROÏNES NACIONALS A LA HISTORIA GLOBAL}

Aquest text es planteja a partir dels recents estudis centrats a les dones guerreres i els herois i heroïnes nacionals com a un fenomen transnacional i global durador i complex amb la finalitat de reexaminar la figura de l'icònic exemple espanyol d'Agustina d'Aragó. De forma concreta explorem cóm i per què ella, i no d'altres, va convertir-se en una heroïna nacional, cóm els espanyols generaren la subversió dels rols de gènere que representava una dona guerrera, l'impacto de la seua prolongada supervivència als esdeveniments de 1808 que la van fer famosa i l'abast i les formes en que la seua figura com a dona guerrera circularà més enllà de la mateixa Espanya.

Paraules clau: Guerreres, heroïnes, dones, gènere, historia global 
The eighty prints of Francisco Goya's Disasters of War present a panorama of virtually unrelieved horror and barbarism. French and Spaniards, men and women, soldiers and civilians: all are perpetrators and victims of savage violence. There is very little that is redeeming here. One exception is print number seven. A single woman in a white dress, bodies at her feet, stands beside a cannon which she is about to fire. Goya's lapidary caption: "Qué valor!", provides a discordant positive comment.

The woman in the print has her back to us but she is far from anonymous. Unlike the other scenes Goya portrays, either of generic violence or actual events involving nameless - and faceless - people, the protagonist of print number seven has a name, and one which has a distinguished place among Spain's pantheon of national heroes. She is Agustina de Aragón.

The topic of hero cults in modern Europe has attracted considerable attention: Special issues of European History Quarterly in October 2007 and July 2009 are but two indications.' This literature has repeatedly highlighted the

1 October 2007 on gender war and the nation in the period of the Revolutionary wars, and July 2009 on hero cults and the nation. 


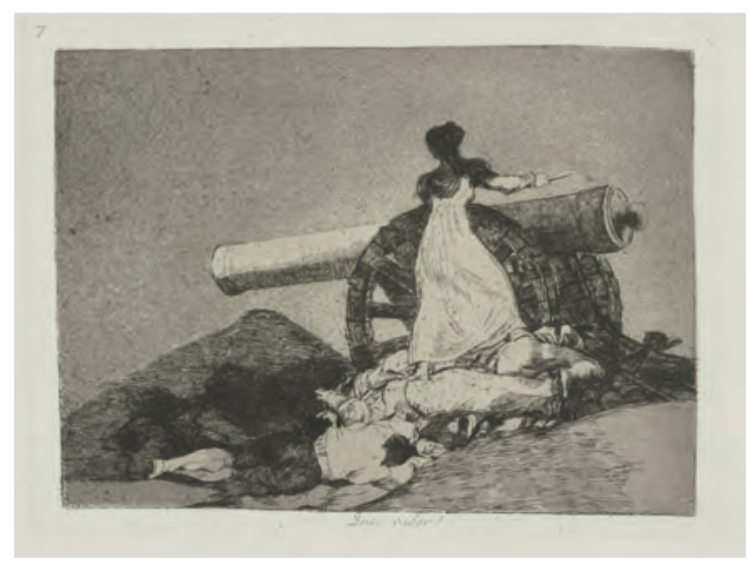

Fig. 1. Photo credit: Yale University Art Gallery.

role of gender: in the European context, heroes have been "overwhelmingly male" and that "most national hero cults in modern Europe emphasized male virility and strength while the unheroic 'other' against whom the narrative was principally directed was often feminized". ${ }^{2}$ They have also pointed out that "war, along with revolution unsettled gender norms in ways that could not be undone" and produced the apparently paradoxical trends of the establishment of complementary and separate spheres of male and female activity, alongside the presence of women engaged in a range of public activities during the war". ${ }^{3}$ The literature on heroes has gone beyond studies of individual nations to look at the broader European context. As Robert Gerwarth puts it in his introduction to the recent special issue of European Historical Quarterly devoted to hero cults and the nation, one of the editors' objectives was to begin to develop "a more integrated, Europeanized perspective on the politics of the past". ${ }^{4}$

2 GERWARTH, Robert (2009) "Introduction", European Historical Quarterly, vol. 39, p. 385.

3 HAGEMANN, Karen, AALESTAD, Karen and MILLER, Judith (2007), "Introduction", European Historical Quarterly, volume 37, p. 504, and HAGEMANN, Karen, AALESTAD, Karen and MILLER, Judith A. (2007), "Preface", Historical Quarterly, vol. 37, p. 499.

4 GERWARTH, "Introduction", p. 383. 
The recently-published collective volume Women Warriors and National Heroes: Global Histories has taken the question much further, approaching it as an enduring and complex transnational and global phenomenon that contains both "common patterns that have emerged across cultures through the telling and retelling of these stories, and pointsof divergence that reveal the specificities of each local context". Its twelve contributors explore cases from Canada, Chile, China, Greece, India, Japan, Mexico, the Ottoman Empire, Peru, Spain, the United States, Vietnam, and Zimbabwe that give rise to a number of questions: how these figures are made and unmade over time; how the "critical disjuncture" of violent women is negotiated; how their subverting of gender roles is managed; and what happens when the women warriors who are turned into heroes outlive the events that made them famous. As well as emerging in separate places around the world, some of these figures were also transnational in that they traveled beyond the borders in which the actual flesh-and-blood women lived. They also cluster in two historical moments: the period of nation building and heightened nationalism in the last third of the $19^{\text {th }}$ century and first third of the $20^{\text {th }}$ and the years of unprecedented warfare, occupation and resistance of World War II and the decades of anti-colonial conflict that followed it. ${ }^{5}$ Agustina de Aragón is not the subject of a comprehensive study in that volume but she mentioned a number of times. ${ }^{6}$

Agustina de Aragón has been the subject of considerable historical writing recently, but she is almost exclusively considered within a purely Spanish national context. ${ }^{7}$ My 2012 article in the Journal of World History that was the seed of the collective volume did analyze her experience in a comparative frame, alongside those of two figures from India's First War of Independence against the British in 1857: Lakshmibai, the Rani of Jhansi, and Jhalkaribai. ${ }^{8}$ This paper proposes to revisit this classic example of a woman warrior and

COTHRAN, Boyd, JUDGE, Joan and SHUBERT, Adrian (eds.) (2020), Women Warriors and National Heroes: Global Histories, Bloomsbury, London, pp. 3 and 7-8.

COTHRAN, JUDGE and SHUBERT (eds.), Women Warriors, pp. 1, 2, 6, 7, 13, 59, 61, 162 and 163.

7 TONE, John Lawrence (2007), "A Dangerous Amazon: Agustina Zaragoza and the Spanish Revolutionary War, 1808-1814", European History Quarterly, vol. 37, pp. 548-61; UCELAY DA CAL, Enric (2009), "Agustina, la dama del cañón", in CASTELLS, Irene, ESPIGADO, Gloria and ROMEO, Mari Cruz (eds.), Heroínas y patriotas. Mujeres de 1808, Cátedra, Madrid, pp. 193-265; and QUERALT DEL HIERRO, María Pilar (2008), Agustina de Aragón, la mujer y el mito, La Esfera de los Libros, Madrid.

8 SHUBERT, Adrian (2012), "Women Warriors and National Heroes: Agustina de Aragón and Her Indian Sisters", Journal of World History, vol. 23, pp. 279-313. 
national hero in the light of what has been learned through this new global approach. Specifically, in this article I will explore the Agustina phenomenon in terms of how she, and not others, was turned into a national hero; how Spaniards managed the subversion of gender roles that a woman warrior represented; the effect of her long outliving the events of 1808 that made her famous; and the extent to and ways in which her figure as a woman warrior traveled.

\section{Agustina's STORY}

What did Agustina de Aragón do to become famous? In June 1808, a French army under General Lefebvre undertook a siege of the city of Zaragoza in northeastern Spain. Despite being vastly outnumbered and seeing much of the city laid to waste by the French assault, a junta under the command of Captain General José Palafox resisted the siege and compelled Lefebvre to lift it. Among the residents of the city was a young woman by the name of Agustina Saragossa y Domènech. Born in Barcelona in 1786, Agustina, with her young son, had gone to Zaragoza in the spring of 1808 , following her husband, a junior artillery officer. Women played an important role in defending cities against sieges, especially carrying water and other provisions to the men who were fighting. Agustina was occupied in these tasks when the heroic moment presented itself. One British observer described Agustina: "Her countenance is mild and feminine; her smile pleasing and her face altogether the last I should have supposed to belong to a woman who had led troops through blood and slaughter and pointed the cannon at the enemy". ${ }^{9}$ General Palafox arrived at the scene shortly after Agustina's exploit, giving her a decoration and inducting her into the artillery as a soldier.

Historians rarely have the privilege of hearing women such as Agustina de Aragón express themselves in their own words, but in August 1809 she recounted the exploit that made her famous in a petition to the king. Agustina signed the petition but it was almost certainly drafted by someone else, presumably a lawyer or notary. Still, it contains touches one would not expect to find in a document addressed to the king and which may well be the sound of Agustina's own voice. "Pregúntese, Señor, quien hizo los primeros fuegos de la batería de la puerta del Carmen... Pregúntese quien se presenta delante de nuestra Tropa cuando... se trató de desalojar [a los

9 Cited in FRASER, Ronald (2008), Napoleon's Cursed War, Verso, London, p. 165. 
Franceses] ... Pregúntese, Señor, que hizo esta Artillera a los tres o cuatro días que se repitió la misma salida...". ${ }^{10}$

Agustina "salió de Barcelona hacia la capital de Aragón a principios de Junio de 1808" and arrived "quando empieza a ser atacada por los Franceses. She immediately became involved in the defence of the city, taking up the usual women's role of encouraging the soldiers by "sirviendo tacos y otras provisiones". When the French began to bombard the Portillo gate, Agustina "pónese entre los Artilleros, los socorre, los ayuda y dice 'aquí hay mugeres cuando no podáis más'". Then came the key moment.

No había pasado mucho rato quando cae de un balazo en el pecho el cabo que mandaba al favor de otro jefe, al qual se retiró por muerto, y caen también de una Granada y abrasados de los cartuchos que volan casi todos los Artilleros, quedando por esta desgracia inutilizada la batería y espuesta a ser asaltada. Con efecto, ya se acercaba una columna enemiga quando tomando la Esponente un botafuego pasa por entre muertos y heridos, descarga un canon de a 24 con bala y metralla aprovechada de tal manera que levantándose los pocos Artilleros de la sorpresa en que yacían a vista de tan repentino azar, sostiene con ellos el fuego hasta llegar un refuerzo de otra puerta y oblige al enemigo a una vergonzosa y precipitada retirada.

Shortly afterwards, "la condecora el General [Palafox] con el título de Artillera y sueldo de seis reales diarios".

This was not the end of Agustina's service. She continued to work "en esta batería y en las demás a donde cargaban los Franceses". In addition, she would leave the battery "por auxiliar donde más era necesario, con municiones, víveres y demás" When Palafox saw her at this work "la concede los dos escudos con el lema Defensora de Zaragoza y Recompensa al Valor y Patriotismo". With her "entusiasmo patriótico" still strong, Agustina remained in the city when the second siege began at the end of December 1808 , and she continued to act valiantly. "La Esponente, deteniéndose en medio de tanto peligro, quitó a un tambor francés la caja, cogía dos fusiles de los muertos y lo presenta todo al Comandante de su bateria". Only "la cruel peste" that hit city could do what the French had been unable to: "hacerle desistir de su empeño de resistir a tan vil cañalla". Agustina was

10 Archivo General Militar, Segovia, Celeb., Caja 176, exp. 4. The following quotations are from this same document. Emphasis added. 
on her sickbed when she heard the news that the city had finally fallen: "Pónese en pie, consigue que la ayuden a vestir, y también a su hijo de cinco años que se hallaba en igual estado, quiere salir huyendo, cae en manos del enemigo, y no falta quien dice 'ésta es la Artillera'". She and her son were forced to march with the other prisoners. They managed to escape but the child died soon afterwards "a la fuerza del contagio, fatiga del camino y falta de recursos para su asistencia". Agustina made it to Tervel, where the Governor gave her travel documents for Seville and two generals provided introductions to people there. "Señor, En vista de estos y otros hechos que no puede menos de gloriarse la Artillera Zaragoza con toda la Nación, qué no debe esperar de la generosidad con que VM sabe premiar el valor y el patriotismo más acendrado??" The petition bears a marginal note signed by Palafox confirming that what Agustina says in the document is true; "ha merecido por su valor y Buenos servicios las distinciones que usa y que es muy merecedora a la gracia que solicita".

Agustina's account is long on details of her exploits; indeed, those in the second siege receive more attention than her famous firing of the cannon during the first. It is, in contrast, short on her motivations. The French are frequently described as "el enemigo" and once as "vil canalla". Patriotism is mentioned twice. More ideological motives, such as defence of religion or the legitimate king, are totally absent. And personal motives, including romantic love or defence of family are equally scarce. Indeed, Agustina's references to her young son are minimal and tangential. Even his death is mentioned in a totally matter-of fact-way.

Up until the moment she fired the cannon, Agustina de Aragón was engaged in the well-established role of women in early modern European siege warfare. Sieges were considered attacks "on the community, and as on other occasions when the community required protection, such as food riots", women took an active part. ${ }^{11}$ This view is shared by Irene Castells, Gloria Espigado and María Cruz Romeo in their introduction to a volume on Spanish women during the war against Napoleon. The power vacuum caused by the invasion and the rhetoric about "the Spanish people" made a space for women, who were stimulated by the political and cultural implications of the conflict: religion and family as well as the monarchy. "Por

11 HOPKIN, John David Hopkin (2007), "Sieges, Seduction and Sacrifice in Revolutionary War: the 'Virgins of Verdun'", European History Quarterly, vol. 37, p. 531. Also LYNN II, John A. (2008), Women, Armies and Warfare in Early Modern Europe, Cambridge University Press, Cambridge, pp. 164-165. 
eso, y desde el principio, la prensa, los manifiestos, los proclamas, las representaciones plásticas de los acontecimientos de la Guerra, al tiempo que modulaban una idea de nación, se hacían eco de las gestas femeninas. Comenzó entonces un proceso de glorificación de las heroínas". ${ }^{12}$

\section{Why Agustina? Making a Hero}

However, very few European women were subsequently elevated to their country's pantheon of national heroes. Agustina de Aragón was immediately celebrated for her role in the defence of Zaragoza against the French in 1808 and has retained a place as a national icon, perhaps the only individual Spanish woman to do so. How did this happen? How was Agustina made as a national hero and why has she remained one?

Turning a woman warrior into a national hero "is not a straightforward process" and once attained "heroic status remains both contingent and contested". ${ }^{13}$ Agustina was far from being the only woman who took part in the defence of Zaragoza; nor was she the only one who was recognized at the time for her contributions or memorialized in visual representations. These began to appear almost immediately. The commander of Zaragoza, José Palafox, was unusually attentive to public relations and after the first siege had been lifted he invited a number of artists, Goya among them, to the city. Juan Gálvez and Fernando Brambila also went, and the visit led to the "popularísima" Las Ruinas de Zaragoza, which was one of the very first artistic renderings of the sieges. Their album consisted of 24 prints of the siege, followed by twelve "retratos de los principals heroes y heroínas, elegidos entre las personalidades que más se distinguieron en el primer $\mathrm{Si}$ tio", among them Agustina and three other women heroes: María Agustín, Casta Alvarez and the Countess of Bureta, as well as a battle scene entitled Combate de las zaragozanas con los dragones franceses. ${ }^{14}$ Yet it was

12 CASTELLS, Irene, ESPIGADO, Gloria, and ROMEO, Mari Cruz (2009), "Heroinas por la patria, madres para la nación: mujeres en pie de guerra", in CASTELLS, ESPIGADO and ROMEO (eds.), Heroínas y patriotas, pp.22-23 and 43.

13 COTHRAN, JUDGE and SHUBERT, "Introduction", in COTHRAN, JUDGE and SHUBERT (eds.), Women Warriors, p. 1.

14 GASCA, Cecilio,(1905), Album de los Sitios de Zaragoza, Tipografía de Mariano Salas, Zaragoza p. ix. The defence of Zaragoza was also immediately glorified in other media as well. As early as 1809, audiences in Madrid could see performances of Gaspar de ZAVALA'S play, Los patriotas de Aragón, Ramón Ruiz, Madrid. There were also numerous epic poems. GARCÍA CARCEL, Ricardo (2007), El sueño de la nación indomable, Planeta, Barcelona, p. 168, fn 10. 
Agustina alone who stuck in the national memory and achieved the status of national hero, while the others were all but forgotten. ${ }^{15}$ She remained a popular subject throughout the $19^{\text {th }}$ century and into the present, ${ }^{16}$ and she has been represented in a wide range of media, both visual and otherwise: painting, sculpture, music, theatre, fiction, advertising, movies and, most recently, graphic novels. ${ }^{17}$

The answer to "why Agustina?" has various components. In part, it lies in timing. The high point of her importance and popularity came in the century between 1850 and 1950 when she was the subject of innumerable history paintings, zarzuelas, and two movies.

The upsurge in Agustina's popularity coincided with the take-off in interest in the national history in the second half of the $19^{\text {th }}$ century. This fits with the global chronology mentioned earlier. The publication of Modesto Lafuente's multi-volume Historia General de España, which began in 1857, marked what José Alvarez Junco has called "a veritable collective obsession" for history writing in Spain, one that engaged a multi-generational group of intellectuals and produced "the canonical version of the past in national terms". ${ }^{18}$ And this national version of the past needed "heroic figures who defended their nationor community against an invading force and thus came to personify the nation-state". ${ }^{19}$ That Goya's Desastres de la Guerra, with its representation of Agustina firing the cannon, was finally published in 1863 supports this argument. In 1870, her remains were transferred from Ceuta, where she had died, to Zaragoza. They landed on the peninsula at Cádiz, where "fueron escoltados y conducidos con la mayor pompa possible a la iglesia de San Juan de Dios". The colonel in charge of receiving the remains

15 Not entirely forgotten, though: the Aragonese artist Marcelino de Unceta painted a portrait of Casta Alvarez in 1875. The mausoleum in which her remains were interred in 1908 was not for Agustina alone: it was called the Panteón de las Heroínas, and here she rejoined the other women who had stood out in the defence of Zaragoza.

16 In January 2010, Rosa Crespo, a female police officer who was serving with the United Nations in Haiti and died in the earthquake was described as an Agustina de Aragón. El País, January 20, 2010 [www.elpais.com/articulo/internacional/Rosa/era/solidaria/siempre/estaba/dispuesta/colaborar/elpepiint/20100120elpepiint_3/Tes].

17 During the 1808 bicentenary celebrations, there was also a Facebook page - now extinct -(http://www.facebook.com/pages/Agustina-de-Aragon/126322070592) about her.

18 ÁlVAREZ JUNCO José (2001), Mater Dolorosa: la idea de España en el Siglo XIX, Taurus, Madrid, pp. 201-202.

19 COTHRAN, JUDGE and SHUBERT (eds.), Women Warriors, p. 7. 
described as Agustina as "la ínclita heroína", "esa gloria nuestra, que lo es nacional" and "inmortal heroína". ${ }^{20}$

A second factor was the political malleability of Agustina's act, a valuable quality in a country with competing visions of the national history. ${ }^{21}$ She became, to use Marina Warner's description of Joan of Arc, "a diviner's cup, which reflects on the surface of the water the image that the petitioner wants to see". ${ }^{22}$ Joan herself has been claimed by clericals and republicans in the nineteenth century, by Vichy and the Resistance during the Second World War, and, most recently, by both the far-right Front National and gay rights activists. The selection of a mixed-race girl to portray Joan in the annual Joan of Arc festival in Orléans in February 2018 generated a torrent of racist abuse. ${ }^{23}$ Agustina has been almost as malleable. Even during the Spanish Civil War, she was used as an example by both sides. For the Republic, which put out a stamp to her in 1939, Agustina was "la primera miliciana sobre el solar ibérica, una mujer del pueblo que legó a los españoles su ejemplo "luchando heroicamente por nuestras libertades". One Communist Party leaflet from December 1937 called on the women of Madrid, as "descendants of AGUSTINA DE ARAGÓN", to inspire "a tu compañero, hijos y hermanos, aunque en la ruda pelea dejes jirones en tu propia vida".

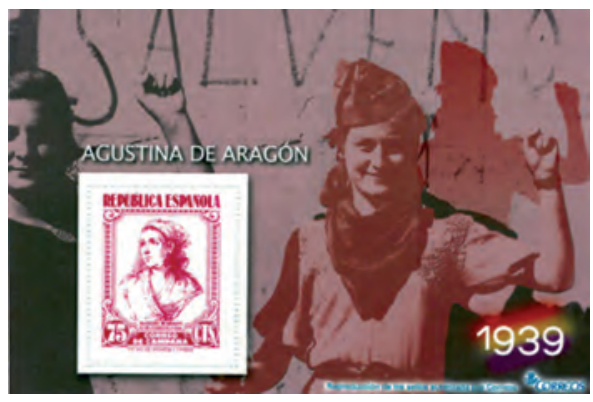

Fig. 2. Author's collection.

20 Twenty years later, her grandson donated her medals and other souvenirs to the state. His mother, he said, motivated by "rectos principios del Patriotismo", had refused various purchase offers from foreigners. The grandson proposed that the donation take place on May 2, and that the military parade be extended the short distance from the monument to the heroes of the Dos 
For the Nationalists, she was an icon of the national struggle against the foreign invader, a precursor to the Generalísimo himself:

Agustina de Aragón, la heroína del primer Alzamiento Nacional General Francisco Franco, director del Segundo Alzamiento Nacional. ${ }^{24}$

Finally, and perhaps most significantly, there was the nature of Agustina's heroism. The interest in national history extended to the arts, especially painting, and Agustina's moment, a single, highly dramatic act, leant itself perfectly to visual representation.

Agustina benefitted from the tremendous surge in importance of history painting in the second half of the $19^{\text {th }}$ century, a surge prompted by the inauguration of the Exposiciones Nacionales de Bellas Artes in 1856. According to one art historian, these Exhibitions were responsible for history painting taking the place of religious painting. The prize money offered certainly supports this claim: the winning painting in the history category received 90,000 reales, compared to 35,000 for religious paintings and only 17,500 for landscapes. Over the life of the Exhibitions, artists entered 625 works with historical themes, of which 52 dealt with the War of Independence. Of these, the sieges of Zaragoza, with eleven paintings, were the favoured theme, eclipsing even the uprising of May 2, 1808 in Madrid and in this work Agustina was the most frequently repeated icon. ${ }^{25}$

de mayo to the Military Museum. The second part of the request was rejected and the ceremony took place at the monument.

21 BOYD, Carolyn (1997), Historia Patria: Politics, History, and National Identity in Spain, 1875 1975, Princeton University Press, Princeton.

22 WARNWER, Marina (1999), Joan of Arc: The Image of Female Heroism, University of California Press, Berkeley, p. 7.

23 "French Far Right Attack Choice of Mixed-Race Girl for Joan of Arc Role", The Guardian, February 23, 2018 [https://www.theguardian.com/world/2018/ feb/23/french-far-right-targets-mixed-race-teen-playing-joan-of-arc] (accessed February 19, 2020).

24 NÚÑEZ SEIXAS, Xosé Manoel (2006), Fuera el invasor, Marcial Pons, Madrid, pp. 87-88, 232-33; UCELAY DA CAL, "Agustina, la dama del cañón", in CASTELLS, ESPIGADO and ROMEO (eds.), Heroínas y patriotas, p. 211 ; and CARBAYÓ-ABENÁZAR, Mercedes (2001), "Shaping Women", National Identity through the use of Language in Franco's Spain", Nations and Nationalism, vol. 7, p. 86. 
This iconography was highly standardized: other than in the Disasters of War, which were not known until 1863, Agustina is shown from the side with her face plainly visible, either in profile or facing the viewer. The only significant difference was whether or not a priest was included, and in this regard the outliers have been by two foreign artists. In his Defence of Zaragoza, Englishman David Wilkie put a priest in a prominent position, crouching close to Agustina, engrossed in writing while she fires the canon. ${ }^{26}$

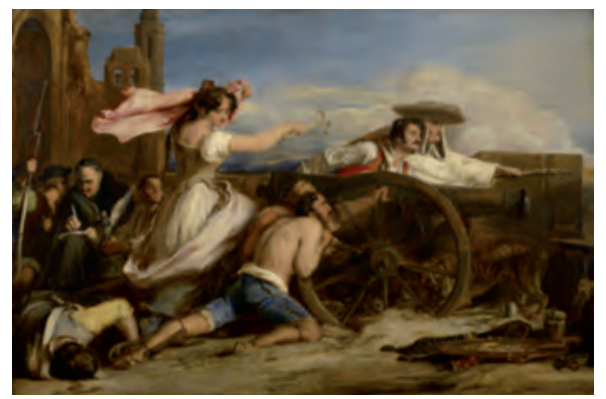

Fig. 3. https://www.rct.uk/collection/405091/the-defence-of-saragossa.

The French artist, Augustin Burdet, makes the priest more prominent still: standing next to Agustina, cross raised and pistol is his belt. While clergy did play a role in the resistance to Napoleon, and some even became guerrilleros, the fact that no representation by a Spanish artist includes them

25 GUTIÉRREZ BURÓN, Jesús (1989), "La Fortuna de la Guerra de la Independencia en la Pintura del Siglo XIX", Cuadernos de Arte e Iconografía, volumen 2, p. 350-54; ÁLVAREZ JUNCO, Mater Dolorosa, p. 251; and REYERO, Carlos (1985) "Los sitios de Zaragoza", in Actas III Coloquio de Arte Aragonés", Diputación General de Aragón, Zaragoza, p. 325.

26 Enric Ucelay da Cal argues that Wilkie's Agustina is "highly sexualized, the negation of the embodiment" of the nation. UCELAY DA CAL, "Agustina, la dama del cañón", pp. 204-205. 
suggests that Wilkie and Burdet may well have been motivated by either the common foreign view that Spaniards were a particularly priest-ridden people or the Romantic image of the warrior priest. Agustina firing the cannon is the moment shown in virtually all the visual representations. Only a couple of portraits, both of which show her in uniform, do not refer to it. Even Juan Gálvez's 1810 portrait, which does not portray the battle but puts Agustina in a pastoral setting, has her leaning against a cannon with dead bodies at her feet.

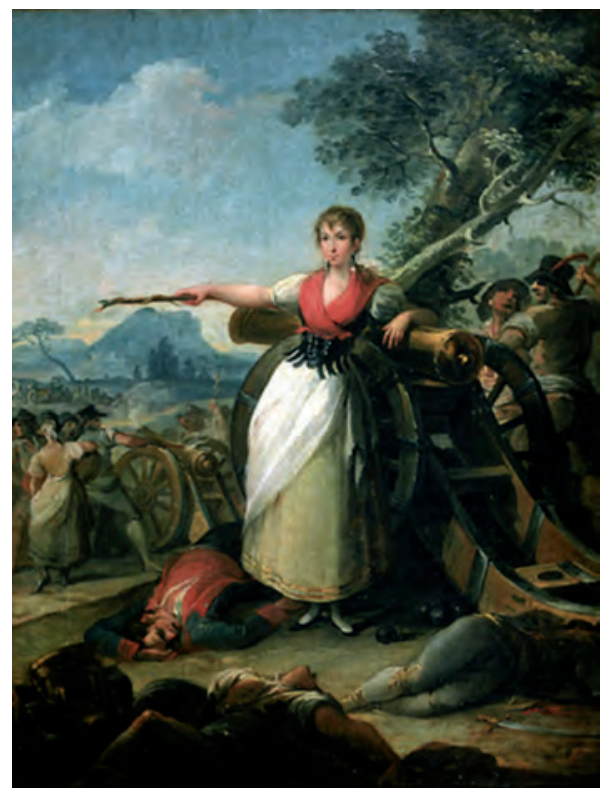

Fig. 4. Juan Gálvez, Agustina de Aragón

(C) Museo Lázaro Galdiano. Madrid.

What was true of painting was also true of monuments. The late $19^{\text {th }}$ and early $20^{\text {th }}$ centuries were the moment that Carolyn Boyd has called "monument mania" and Carlos Reyero and Ignacio Peiró Martín see as a "Golden Age of the public monument" that contributed to the creation of a "landscape of official memory". ${ }^{27}$ This is part of what Joep Leerssen has presented as 
the continent-wide phenomenon of "Romantic Nationalism" which included, among many other things, making public spaces "increasingly nationalized and historicized by architectural, pictorial and sculptural means". ${ }^{28}$

The celebration of the first centenary in 1908 gave Agustina's public profile a major boost. Zaragoza was the "epicenter" of the celebrations and the only place in the country to receive funding from the national government. (This supports Stephane Michonneau's findings for Barcelona between 1830 and 1930 about the primacy of local rather than state initiative in Spanish memory politics before the Primo de Rivera dictatorship. ${ }^{29}$ Most of the events emerged from local initiatives and the celebration reflected the struggle between Catholics and liberals and republicans. The Church made a major effort to infuse the centennial with a religious flavor and it succeeded quite well. ${ }^{30}$ King Alfonso XIII and most leading politicians were in the audience when Canon Florencio Jardiel gave the eulogy for the heroes of the sieges in which he described patriotism as the "baluarte" of religious faith. For his part, the Cardinal-Archbishop of Zaragoza described the struggle against Napoleon as less a patriotic war than a religious crusade. The celebrations also stressed local heroes, especially the women, and here Agustina had pride of place. Her act of glory filled one face of the monument to the heroes of the siege that was inaugurated in the presence of Alfonso XIII, and he presided over the transfer of her remains from the cathedral to a specially constructed mausoleum in the church of Our Lady of the Portillo. ${ }^{31}$

27 BOYD, Carolyn (1999), "Statue-mania in 19th-century Spain", Paper delivered at the annual meeting of the Society for Spanish and Portuguese Historical Studies, April 1999; REYERO, Carlos (2009), "El reconocimiento de la nación en la historia. El uso espacio-temporal de pinturas y monumentos en España", Arbor, vol. 185, p. 1206; and PEIRÓ, Ignacio (2017), En los altares de la patria, Akal, Madrid. See also CASTELLS, Luis (2010), "Celebremos lo local, celebremos lo nacional. Política estatuaria en el País Vasco (1860-1923)", in Procesos de nacionalización en la España contemporánea, Universidad de Salamanca, Salamanca, pp. 355-378.

28 LEERSSEN, Joep (2014), "When was Romantic Nationalism? The Onset, the Long Tail, the Banal", NISE Essays, 2 [http://nise.eu/news/new-publication-on-romantic-nationalism/], p. 13.

29 MICHONNEAU, Stéphane (2007), Barcelone: Mémoire et identité 1830-1930, Université de Rennes, Rennes, p. 13.

30 MORENO LUZÓN, Javier (2007), "Fighting for the National Memory: The Commemoration of the Spanish 'War of Independence', 1908-1912", History and Memory, vol. 19, pp. 75-80.

31 Cited in PEIRÓ, Ignacio and RÚJULA, Pedro (2000), Trabajo, Sociedad y Cultura. Una Mirada al Siglo XX en Aragón, Publicaciones Unión, Zaragoza, p. 282. 
Agustina's moment appears on the monument to the sieges of Zaragoza, and it is also the subject of the monument in Fulleda, her parents' home town. Mariano Belliure's 1902 statue in the Zaragoza city hall is a partial exception. It does not show Agustina firing the canon but does make reference to it. The statue consists of a bust of Agustina perched atop a vertical canon covered in wreaths. ${ }^{32}$ The image proved so powerful that it was quickly co-opted for other purposes, including the cover of the sheet music for Justo Blanco's jota "Agustina de Aragón", published in 1893, which before was illustrated with a drawing of Agustina firing the canon; the dead soldiers at her feet were accompanied by a crossed rifle and guitar.

Just as Spain has had competing nationalisms, Agustina's role as a national icon has not gone uncontested. Basque nationalism, with its particular take on the role of women, has been keen to create its own pantheon, including creating its own women warriors. In his role as playwright, Sabino Arana would create the figure of Libe as a genuine Basque woman warrior; twelve years later she would be cast as a much more feminine figure by Manuel de la Sota. In the meantime, Sorne Untzueta, leader of the Basque nationalist women's organization Emakume Abertzale Batza declared that the movement had no need for figures like Agustina de Aragón or Joan of Arc: the "total volume of work undertaken" by Basque women was more "interesting." ${ }^{33}$

\section{Representing - and Domesticating - Agustina}

How did Spaniards manage the subversion of gender roles that a woman warrior represents? The most common strategy is "to have these intrepid heroines revert to their feminine roles shortly after performing their feat of bravery". ${ }^{34}$ Many visual representations did just this, portraying Agustina in the women's clothes she would have worn at the time. Both David Wilkie and Agustin Burdet do so, as do almost all of the Spanish artists who rendered her, such as Juan Gálvez and Goya himself. Miguel Navarro Cañizares' Defence of Zaragoza (1862), which was later used on a sherry label by the Fuentes Parrilla company, is an excellent example. The posters for both movies about her show Agustina in woman's clothes, although the one for Florian Rey's 1928 film represents her as almost masculine in her ferocity.

32 Cited in Zaragoza y los sitios, (Zaragoza, 1952), p. 35.

33 ARESTI, Nerea, "Women Warriors or Mothers of the Fatherland: Hero Cults and Gender in Basque Nationalism", in COTHRAN, JUDGE and SHUBERT (eds.), Women Warriors, pp. 59-61. 


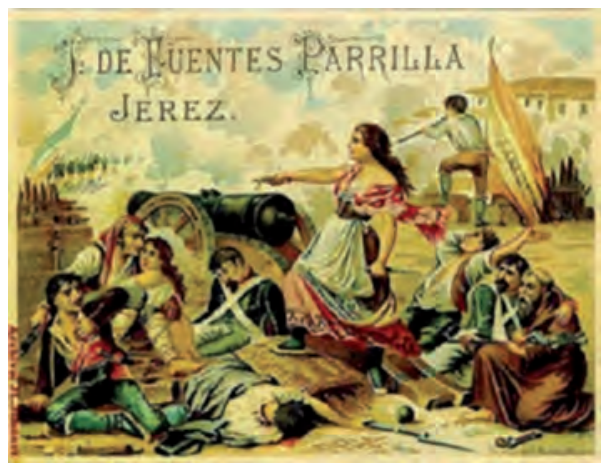

Fig. 5. Early twentieth-century sherry label based on The Defence of Zaragoza by Miguel Navarro Cañizares (1862).

Courtesy of José Luís Jiménez.

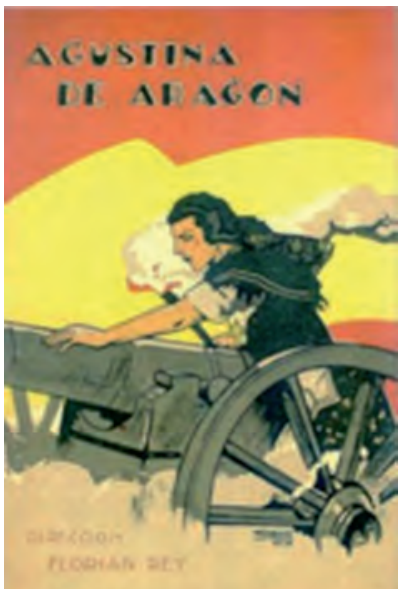

Fig. 6. Biblioteca Nacional de España.

There are also a number of exceptions, including what was likely the first portrait of Agustina ever done. In a miniature painted by a Col. Landmann while she was in Gibraltar in 1809 she appears wearing a military tunic. Another exception was the portrait painted by Lucio Rivas, now exhibited in the Museo del Ejército in Toledo, that shows her standing next to a cannon wearing a military tunic, her medals, and a sword. In 1885, Agustina's granddaughter, Agustina Atienza Cobos, painted another portrait of her in military uniform. A commission from the ayuntamiento of Zaragoza, the painting and was exhibited in the Exposición Aragonesa of 1885-1886. ${ }^{35}$

34 COTHRAN, JUDGE and SHUBERT, "Introduction", p. 11.

35 In 2009, the city of Zaragoza named a street after Agustina Atienza Cobos. It had previously born the name of a Francoist officer, Coronel Arce [https://www.elperiodicodearagon.com/ noticias/temadia/coronel-arce-nieta-agustina_492335.html]. In 2017, the mayor of Zaragoza, Pedro Santisteve (Podemos) replaced the portrait of King Felipe VI in his office with the portrait of Agustina de Aragón. [https://intereconomia.com/noticia/alcalde-zaragoza-cambia-retrato-del-rey-despacho-agustina-aragon-20170210-1333/]. 


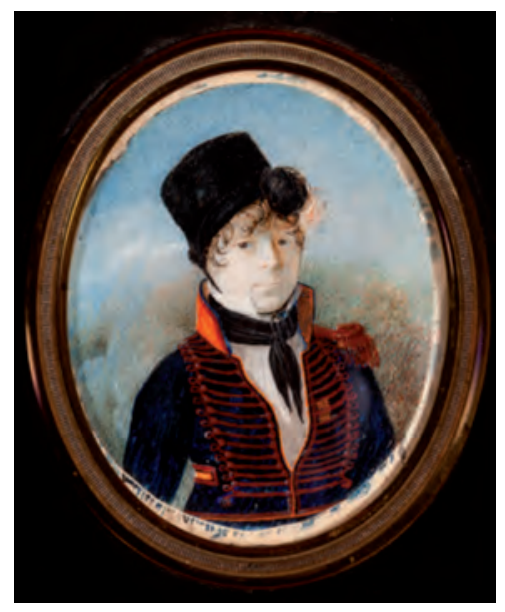

Fig. 7. Anónimo

Retrato de Agustina de Aragón, h. 1809.

Acuarela. Fundación Ibercaja. Museo

Goya, Zaragoza.
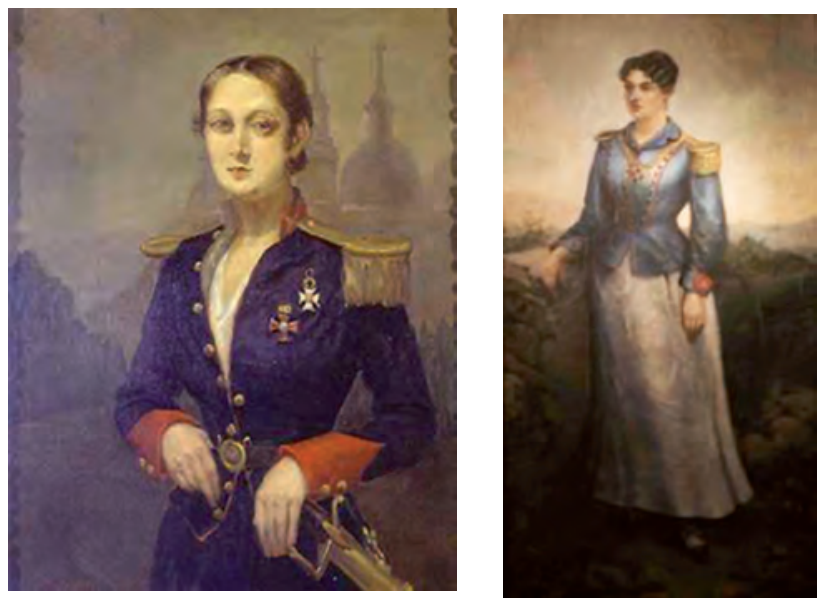

Fig. 8. Left: https://www.alamyimages.fr/agustina-saragosse-je-domenech-conocidacomo-agustina-de-aragon-1786-1857-subteniente-infanteria-auteur-lucio-ribas-emplacementalcazar-museo-del-ejercito-coleccion-toledo-espagne-image208186218.html

Fig. 9. Right: http://www.zaragoza.es/ciudad/cultura/patrimonio/detalleBien_ PatrimonioCulturaleid $=513$ 
Two monuments in Zaragoza inaugurated during the 1908 centennial give contradictory images. The monument to the Sieges contains a conventional Agustina, dressed in women's standing beside the cannon she is about to fire. (This is also how she appears in the statue in her home town of Fulleda.) In the monument to Agustina herself, however, she stands atop a cannon, a dead civilian at her feet, wearing a military tunic with prominent epaulettes and her medals.

Other forms of representation: history writing, fiction, theatre and film address Agustina's motivations in crossing the line that separated the "normal" behaviour of women during a siege from the man's role of direct military action. They provide two conflicting answers. The Agustina we find here is driven either by the feminine motivation of love or the masculine motivation of patriotism.

The first important account came from Palafox, the commander at Zaragoza, and he attributed her heroic act to a motivation he himself invented: Agustina was moved to act by the death of her lover, an artillery sergeant. This fiction would have a long afterlife, starting with Lord Bryon:

Her lover sinks- she sheds no ill-timed tear;....

Who can appease like her a lover's ghost?...

Yet are Spain's maids no race of Amazons

But form'd for all the witching arts of love.

This version was repeated by Emilio Castelar in a book on Spanish women published shortly before he became President of the First Republic in 1873. Before describing Agustina's actions, he says that Aragonese women in general "undoubtedly have something manlike about them". Yet, "her first impulse was that of a woman: seeing the sargeant whom she loved dead at her feet" she grasped the fuse from his hands and fired the cannon "with genuine fury" ${ }^{36}$ Writing in 1868, Carlos de Rada said Agustina acted with "noble love for the Fatherland and love for her chosen one in her heart". He then added religion: after firing the canon, she invoked the Virgin of the Pillar. Agustin Coy Cotonat directly rejected Palafox's version; Agustina was not moved by the death of a lover but "solely and exclusively by the duty of a wife and patriot". ${ }^{37}$

36 CASTELAR, Emilio (1873), "La mujer de Zaragoza", in Las mujeres españolas portuguesas y americanas, Miguel Guijarro, Madrid. 
The latest literary Agustina is very different from all her predecessors. The protagonist of the 2009 comic by Fernando Monzón and Enrique Mendoza is very much a $21^{\text {st }}$-century heroine who bears a much greater resemblance to Lara Croft "Tomb Raider" than to her own previous incarnations. The authors describe their Agustina as "Far removed from the archetype of a docile, complacent wife, she embodies values that in literature have traditionally been associated with male characters: taking the lead rather than staying in the background, courage rather than the need to be protected.... She is a woman with a burning desire for freedom, prepared to fight for it till the very last breath". In this version, Agustina's historic heroism is the reaction of a moment, "no decision. It is a reflex". After Zaragoza, she joins the guerrilla and becomes its leader, giving orders to the men in her unit. After an attempt to capture Napoleon's brother, King José, goes awry, she is captured by the French, but manages a daring escape and rides off into the sunset. ${ }^{38}$ Interestingly, this very modern Agustina dresses as a woman, albeit a risqué one.

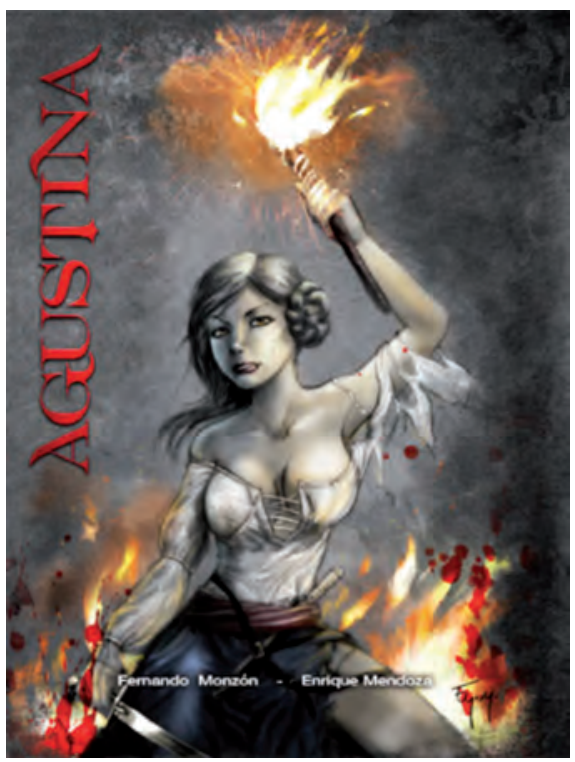

Fig. 10. https://www.fernandomonzon.com/agustina-de-aragon/

37 DE LA RADA, Carlos (1942), Mujeres Célebres de España y Portugal, Espasa-Calpe, Buenos Aires, p. 164; and COY, Agustín (1914), Agustina Saragossa Domenech, Imprenta José Guerra, Ceuta, p. 103.

38 MONZÓN, Fernando and MENDOZA, Enrique (2009), Agustina, 3lemon Soluciones Tecnológicas, Zaragoza. 
Agustina has also been the subject of at least two zarzuelas. The first, $\mathrm{Se}$ bastián Alonso Gómez's Agustina de Aragón, debuted in Zaragoza in June 1907, just before the centenary of the siege. This Agustina is motivated primarily by love, for her husband, for her father and her friend's love for a French sympathizer. The opera begins with Agustina's wedding. A messenger arrives ordering all men under forty to report to the city for military duty. Agustina tries to convince her husband not to go but finally relents, telling him to go "to kill and if necessary to die". Her husband is soon killed; Agustina then goes in search of her father and follows him to the Portillo gate. When he dies manning a canon, she steps up and fires it shouting "Father, you are avenged!" There is also a romantic subplot: Agustina's friend María is in love with Belfort, who has been arrested as a French spy. Agustina agrees to help free him because, as she proclaims: "What heart can be unmoved when love is invoked!" She succeeds, but Belfort breaks his promise not to participate in the attack on the city. Religion has an important role in this zarzuela. The messenger who calls the men to the army says that it is "Our Captain, La Pilarica, [the little Virgin of the Pillar"] who "calls us to her defence". And when Agustina agrees to help Belfort she places her hope in the assistance of "La Pilarica". ${ }^{39}$ Much of this is invented. Agustina was already married and a mother when she arrived in Zaragoza; her husband was a serving soldier; and her father was not in the city during the siege.

The second zarzuela, Agustina de Aragón (La Heroína del Pilar), also debuted in Zaragoza, but half a century later. This Agustina is a very different type of woman: she is driven not by romance but by patriotism, which she places even above religion. She first appears in scene 13, bandaging Pedro, a wounded artillery sergeant. When she has finished she tells him that she has done her duty "as a woman and a Spaniard". Later, she talks of fighting for Spain and for the Fatherland, and when a nun makes a group of women kneel and pray for the Church Agustina adds "and for Spain". Before the big battle, Pedro asks Agustina for a kiss but he is rebuked: if she has to kiss a man, she tells him, "it will be when I'm dead or at the foot of the altar". After General Palafox promotes Pedro, Agustina does fall in love with him. The operetta ends with Agustina telling a group of French officers to let Napoleon know that: 
There is in Spain a fierce and strong people

That knows how to fight to the death...

Tell him that, after winning this campaign

The living who defeated him,

With their bodies will block the road

Of Your Emperor!... This is Spain! ${ }^{40}$

The War of Independence has also been a popular topic for filmmakers, both Spanish and foreign. ${ }^{41}$ Two of these films are about Agustina. The first was made in 1928 by Florian Rey, one of the dominant figures of early Spanish movies, a screenwriter and director committed to building a national cinema. Rey was particularly interested in history as the subject for his work, and his Agustina was one of the first history films made in Spain. Rey was commissioned by a group from Aragon, who provided the backing for the production based on a script that Rey himself wrote. ${ }^{42}$

Only a few minutes of this film remain, but its messages can be reconstructed through the "novelized version" that was published in La novela semanal cinematográfica in 1929. Starting with the siege of Zaragoza, Rey "[i]ntroduces a melodramatic vein, the love story between a Spanish woman and a Frenchman, and the conflicts between duty and emotion that affect the protagonists... This is essential for the development of the character of Agustina because it allows an exploration of her double condition as woman and soldier, which then articulate the film's overall narratives: Spanish national exaltation and a discourse of peace with France" ${ }^{43}$ The message is that Spaniards acted unanimously to defeat the French and that civilians were the real heroes.

40 DE MENDIZÁBAL Federico (1965), Agustina de Aragón (La Heroína del Pilar), Imp. Taravilla, Madrid.

41 Bernard Cornwell's Sharp novels, set during the War of Independence, were made into a 16part television series. There was a French film made in 1909 and an Italian one the following year [http://www.bne.es/es/Micrositios/Guias/Guerra_independencia/GICine/].

42 GARCÍA CARRIÓN, Marta (2008), "Por qué me habéis hecho soldado si no podía dejar de ser mujer. El mito de Agustina de Aragón en su primera recreación cinematográfica", in CASTELLS, ESPIGADO and ROMEO (eds.), Heroínas y Patriotas, pp. 133-135.

43 GARCÍA CARRIÓN, "Por qué me habéis hecho soldado", p. 137. 
Rey's film champions the conservative and, above all, Catholic vision of Spanish identity. The weight of religion was evident even before audiences entered the cinema. The poster showed Agustina wearing a cross, and in the film itself her outsized cross is very visible. A priest has a major role in the movie and Agustina is shown as religiously, even divinely, inspired: in one scene, the Virgin of the Pillar, the patroness of Zaragoza, appears to her and this apparition prompts her to act. The film also presented a Spanish nationalism that also drew on regional identities. Rey emphasized the Aragonese nature of the resistance, using the word baturra, which was evolving from meaning simply a farmer from the region to referring to the region as a whole; having his actors dressed in identifiably Aragonese clothing; and showing the people of the city celebrating their victory with by dancing a jota. ${ }^{44}$

Gender is absolutely central to Rey's film. The battle scene is the climax, and Agustina emerges as the personification of "the Spanish nation in arms... the representation of Spanishness". General Palafox appears to make her an officer, after which she dresses in military uniform. But the roles of woman and patriot do not go together easily. Agustina is shown as a mother and at a key moment her maternal feelings trump her patriotic ones: she frees the French soldier with whom her daughter was in love. Palafox pardons this act of treason when he accepts her explanation that for a woman there is a "law stronger than the law of war". ${ }^{45}$

The second movie about Agustina, the 1950 version directed by Juan de Orduña and starring Aurora Bautista, the Spanish box office star of the day, is much better known. It was one of a large number of history films made in the early Franco period and which presented the regime's National Catholic view of the nation's past. In this Catholic charge, as well as a strong folkloric vein, it resembled Rey's film, but it differed from it in a number of key ways. Where Rey sought to promote French-Spanish friendship, Orduña is strongly

44 In 1935, Rey released Nobleza Baturra, in which Aragonese folklore was central. On the way in which regional sentiment could contribute to a Spanish nationalism see ARCHILES, Ferran (2006), "Hacer región es hacer patria. La región en el imaginario de la nación española de la Restauración", Ayer, vol. 206, pp. 121-147. Agustina herself was the subject of a dispute between Aragonese and Catalans over her origins. In 1914, Agustín Coy Cotonat, an army captain, published a book in which he disputed claims that Agustina was born in Zaragoza. She was, he argued, born in Barcelona of Catalan parents, so that "the blood which ran in her veins was clearly Catalan... she is a pure-blooded daughter of Barcelona". COY, Agustina Saragossa, pp. 4 and 90.

45 GARCÍA CARRIÓN, "Por qué me habéis hecho soldado", pp. 147-148. 
anti-French. And while both films include an important - and completely fictional - love interest, one that conflicts with patriotic duty, they resolve the conflict in opposing ways. The 1950 film shows Agustina going to Zaragoza to join her fiancé. When she arrives, she finds that he is pro-French, which leads her to break off their engagement and take part in resisting the siege. Here she again meets Juan, the guerrilla leader who had saved her from being raped by French soldiers. They fall in love, but Juan is killed in battle. Unlike Rey's Agustina, Orduña's puts patriotism ahead of love. In a striking inversion of the usual gender roles, she is "better than the men at putting the political before the personal: both Agustina's lover and her fiancé... state that their political decisions are motivated by love for her, while she repeatedly takes political decisions on patriotic grounds knowing they threaten the lives of the men she loves". ${ }^{46}$ The film ends with Ferdinand VII giving her a medal and declaring "You are the symbol of all the heroes of Spain".

Agustina was not the only such female protagonist in early Francoist cinema. Strong women were common, at least in the historical films, something surprising for a regime that had systematically turned back the clock on the status of women. It was women who embodied typically male virtues, not men, who were given the role of representing the nation. The Franco regime was far from consistent in this respect. Women "wielding swords not needles" appeared in collections of exemplary women's lives directed at schoolgirls, and Agustina was one of the most popular. However, these women were "represented as taking up arms because their husbands, or other male figures, are either absent, wounded, or recently dead. However bravely... they were forced into their historic role by circumstance, not perceived choice." 47

While there has been no single representation of Agustina, the predominant response to her transgression of fundamental gender norms has been to domesticate her, assigning her motivations such as love and religion,

46 LABANYI, Jo (2016), "Feminizing the Nation: Women, Subordination and Subversion in Post-Civil War Spanish Cinema", in SIELGLOHR, Ulrike (ed.), Heroines without Heroes: Reconstructing Female and National Identities in European Cinema, 1945-1951, Bloomsbury, London, pp. 175-176.

47 ALONSO LÓPEZ, Jesús (2009), "1808-1950: Agustina de Aragón, estrella invitada al cine histórico franquista", in ÁLVAREZ BARRIENTOS, Joaquín (ed.), La Guerra de la Independencia en la Cultura Española, Siglo XXI, Madrid, pp. 379-400; and HARVEY, Jessamy (2007), "Domestic Queens and Warrior Wives. Imperial Models for Spanish Schoolgirls during the Early Francoist Regime", History of Education, vol. 36, pp. 289-290. 
which were characteristically female, even when this had no documentary basis and meant ignoring the actual facts of her life, including the rest of her military activities, of which she herself was so proud but which would not fit these explanations.

\section{Outliving the Heroic Event}

Agustina lived for almost half a century after the events of Zaragoza. What did this mean for her fame? Was she one of those "women who outlive their deeds [and] pose significant challenges"? 48

Agustina was certainly far from shy about using her service in the war to request compensation. She was an active agent in advancing her interests, and the military authorities took her very seriously, as the copious documentation makes clear. (To begin with, her file describes her as: "Branch: Infantry, Title: Heroine, Rank: Junior Lieutenant".) ${ }^{49}$ Thus, in 1814 , she wrote to King Ferdinand, newly returned to Spain after his enforced stay in France, requesting additional funds because her salary was not enough to support her. The king granted her an additional 100 reales per month. In 1822, she successfully to request that her salary be increased, in line with laws passed in 1820 and 1822, and following the death of her husband in 1823 she sought, and received, two payments that were owing to her. Four years later she requested that her salary not be subject to the standard 12 per cent deduction for the Montepío Militar. This requested was denied, on the grounds that she was "bastante recompensada", but she petitioned again, this time successfully, in 1847. Then in 1852, she requested an exemption from the 15 per deduction levied on retirees and that she be declared to be on active duty. The military authorities agreed that such a "mujer singular, sobreponiéndose a su sexo, ha inmortalizado su nombre, ligandose con el hecho más glorioso de nuestra historia contemporánea" should receive the sought-after exemption. ${ }^{50}$ She petitioned yet again the following year, complaining that the exemption was not being honoured by the military authorities in Ceuta, where she was living. Her final petition, again successful, came in 1853 when she requested that her salary be raised to that of a lieutenant. ${ }^{51}$

48 COTHRAN, JUDGE and SHUBERT, "Introduction", p. 11.

49 Her grandson Francisco de Paula Atienza y Cobo was an army officer and is listed in the files as "Grandson of the Heroine Agustina of Aragón". Archivo General Militar, Segovia, Celeb., Caja 176, exp. 4.

50 Boletín Oficial del Ejército, agosto de 1852.

51 These petitions and related documents are in her personnel file, Archivo General Militar, Sego- 
In her successive petitions, Agustina also alluded to her motives, and in the process revealed some ability in maneuvering through Spain's complex and changing political landscape. Her original petition, addressed to the King, although he was captive in France, mentioned only patriotism and hatred of the French. (In his memoirs, Palafox claimed that as she lit the cannon, Agustina cried "Viva España! Viva mi Rey, Fernando VII" It would have been to her advantage to have included this in her petitions to Ferdinand, had she in fact said it.) In her petition of 1814, however, Agustina announces her "decidido amor a su real persona" and says that she had been moved by the desire to "ser útil a VM y a la justa causa que se defendía en 1808 ". The "justa causa", a wonderfully ambiguous phrase that. Writing to Isabella II in 1845, Agustina refers to her innato patriotismo" and her desire to "ser útil a su Rey y a su Patria". ${ }^{52}$

Petitions were private documents but Agustina also sought to shape her image publicly. She wore her medals and military uniform until her death in 1857. There are also unsubstantiated reports that at times she put on a false moustache. ${ }^{53}$ The historical novel La ilustre heroina de Zaragoza, - la célèbre Amazona de la Guerra de la Independencia, by Agustina's daughter, Carlota Cobo, to which Agustina contributed as an interviewee, provides a very different picture from that offered by many male authors. Her Agustina is a real Romantic heroine, with "una fisomanía marcada por el dolor, una belleza que presagia desgracias, un aspecto que infunde respeto. Es generosa y nunca se mueve por intereses materiales". Instead, she is a patriot first and foremost, although one who fights for a traditional Spain and its conservative ruler, Ferdinand VII. For her part, Carlota Cobos had a well-developed sense of public relations, perhaps an inheritance from her mother: as well as enjoying the patronage of Queen Isabel II, she donated her receipts from sales to the army that was fighting a colonial war in Morocco. ${ }^{54}$

via, Celeb., Caja 176, exp. 4. The petitions did not end with Agustina's death. Her daughter Carlota Cobos requested and was granted a pension of 3,300 reales per year for life in 1860, and in 1877 Carlota wrote again requesting payment of money that was owing to her mother when she died. Then in 1895, her grandson, Francisco Cobos, wrote to the army and the parliament on behalf of two of Agustina's grandaughters, who were suffering financially; they were both granted a pension of two pesetas a day by King Alfonso XIII.

52 Archivo General Militar, Segovia, Celeb., Caja 176, exp. 4.

53 GARCÍA CARCEL, Ricardo (2007), El sueño de la nación indomable: los mitos de la Guerra de Independencia, Ariel, Madrid, p. 174 [https://www.elmundo.es/suplementos/croni$\mathrm{ca} / 2007 / 617 / 1187474408 . \mathrm{html}]$.

54 SIMÓN PALMER, María del Carmen (2001), "Agustina de Aragón novelada por su hija", in Homenaje a Elena Catena, Castalia Ediciones, Madrid, pp. 487 and 490. 
Agustina struggled to shape her own image in the remaining fifty years of her life, and she would have been pleased with the immediate response to her death in Ceuta in August 1857. All officers in the garrison were ordered to attend her funeral. There would be "un piquete para hacerle los honores fúnebres que corresponden á la clase de la ilustre finada, con arreglo a lo prevenido en el art. 58, tratado $3 .^{\circ}$, tt. v de la Ordenanza, con el cual irá la banda de música del propio cuerpo, asi como la charanga del batallón cazadores de Barcelona, romperá el corteje fúnebre". ${ }^{55}$ However, Agustina died just at the moment that she and her famous deed would be propelled into public memory like never before. And in this process, she would have no say.

\section{Agustina Circulates}

The figure of Agustina de Aragón circulated beyond Spain. As early as 1813 a young German woman would refer to the exploits of Spanish women as an inspiration: "I have been a soldier for four weeks now! ... In my innermost being I was convinced of committing no bad or hasty act; one need only look to Spain and the Tyrol, and the conduct of their women and girls!" ${ }^{\prime 6}$ Agustina was powerfully present in the Anglophone world. Famously, she appeared in Lord Byron's poem Childe Harold's Pilgrimage (181214). She was also at the centre of prominent British artist David Wilkie's 1828 painting, The Defence of Saragosa. Between 1830 and 1940 she appeared in many of the more than 900 collections of female biographies published in the United States and Great Britain. ${ }^{57} \mathrm{~A}$ very feminine and distinctly unwarlike "Maid of Saragossa" also formed part of a group of "warriors" that included Jeanne d'Arc, Boadicea, Agnes of Dunbar, Emilie Plater, the Rani of Jhansi, Christian Davies, Hannah Snell, and Mary Ann Talbot, in suffragette Cicely Hamilton's stage spectacle, A Pageant of Great Women, which was performed across Britain in 1909. ${ }^{58}$

55 La Esperanza, 16 de julio de 1857

56 HAGEMANN, Karen (2007), "'Heroic Virgins' and 'Bellicose Amazons': Armed Women, the Gender Order and the German Public during and after the Anti-Napoleonic Wars", European History Quarterly, vol. 37, p. 507.

57 BOOTH, Alison (2004), How to Make It as a Woman. Collective Biographical History from Victoria to the Present, University of Chicago Press, Chicago, p. 2.

58 HAMILTON, Cicely (1910), Pageant of Great Women, The Suffrage Shop, London, p. 41. 


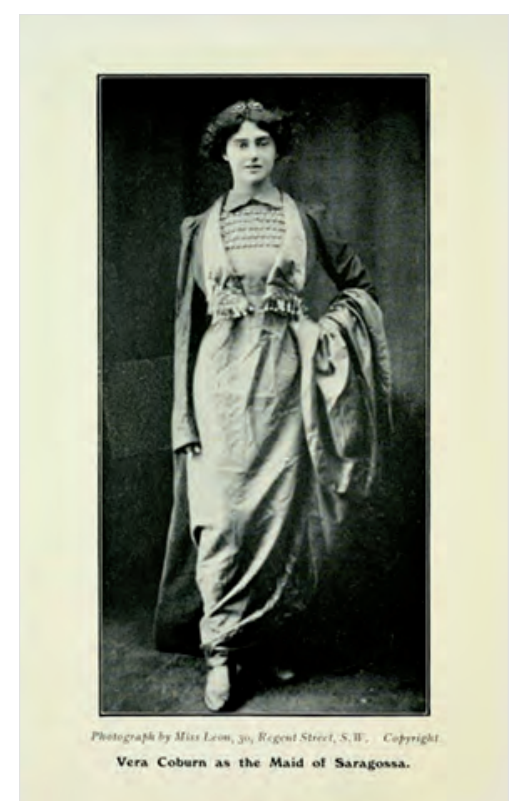

Fig. 11. https://archive.org/details/pageantofgreatwo00hami/page/n57/ mode/2up/search/Saragossa

Agustina also circulated outside the West, appearing in at least two compilations in the late $19^{\text {th }}$ and early $20^{\text {th }}$-century Ottoman world. Butrus alBustani included her in his eleven-volume encyclopedia published in Beirut and Cairo between 1876 and 1900. "When the French besieged the city ... she participated in the defence, growing famous for the courage she displayed. She was called 'Artillery woman' because she wrested a fuse from an artilleryman's hand ... and fired cannon at the besiegers. As reward for her service ... she was given leadership of a soldiers' unit and several medals." She was also among the 456 famous women, including a number of women warriors, in Zaynab Fawwaz's biographical dictionary The Book of Scattered Pearls Regarding Categories of Women. These figures "combined smart strategy-reversing misogynistic notions of 'women's wiles' deployed in Arabo-Islamic polemics to demolish women's public activitieswith strength and loyalty to family and 'nation.' Often, they succeeded to leadership because of kinship ties to men. But they succeeded in leadership through their own abilities". 59 


\section{CONCLUSION}

Agustina de Aragón in Cairo? What is this iconic Spanish figure doing in the early $20^{\text {th }}$ century Ottoman Empire? This unexpected incident becomes intelligible only in the context of an important and enduring global phenomenon: the woman warrior who is made into a national hero. Placing her in this wider frame allows us to understand why the figure of Agustina circulated so widely. It also allows us to ask new questions about the Agustina cult, its creation, evolution and persistence, to see those aspects of it that are widely shared and those that are specific to the local context. This global gaze brings new depth to the history of Spain while, at the same time, taking it out into the wider world. ${ }^{60}$

59 BOOTH, Marilyn Booth, "Jeanne d'Arc, Arab Hero: Warrior Women, Gender Confusion, and Feminine Political Authority in the Arab-Ottoman Fin de Siècle", in COTHRAN, JUDGE and SHUBERT (eds.), Women Warriors, pp. 162-163.

60 For another approach to this question, see LUENGO, Jorge and DALMAU, Pol (2018), "Writing Spanish history in the global age: connections and entanglements in the nineteenth century", Journal of Global History, vol. 13, pp. 425-445. 



\title{
"SI PUDIERA CONVERTIRME EN HOMBRE". GÉNERO, POLÍTICA Y SOCIEDAD: LA REDEFINICIÓN DE LO FEMENINO EN EL LARGO 48 ITALIANO
}

\author{
"IF I COULD BECOME A MAN". GENDER, POLITICS \\ AND SOCIETY: THE REDEFINITION OF FEMININITY \\ DURING THE LONG 1848 IN ITALY
}

\author{
Matteo Morandini \\ Università Roma II, Tor Vergata
}

\section{RESUMEN}

Durante la revolución italiana y europea de 1848, hicieron su aparición nuevos medios o estilos artísticos que entraron rápidamente en el arsenal político que caracterizó la oposición ideológica entre el movimiento nacionalista italiano y la Curia romana. Del análisis de tipologías documentales específicas e inusuales (caricatura, pintura y ficción ficticia), emergen claramente algunos núcleos temáticos que estructuran, en ambos lados, la retórica política y la disputa ideológica: la noción de personas, el anticlericalismo o el anti-republicanismo, pero sobre todo la nueva definición de masculinidad y feminidad, con la definición de los roles correspondientes. A este respecto, la atención obsesiva a la corporeidad femenina y su exposición pública no deseada, que se puede encontrar en ambas producciones, parece referirse al fenómeno más amplio de la afirmación progresiva de la sociedad burguesa y su sistema de valores (nacionalismo) así como la tenaz resistencia del clero destinado a mantener el control sobre las instituciones, la familia ante todo, que consideraba el verdadero depósito de la fe y la base de las relaciones sociales.

Palabras clave: Risorgimento, mujeres, sociedad burguesa, Iglesia católica, Nacionalismo, Caricatura, Novela.

\footnotetext{
ABSTRACT

During the Italian and European revolution of 1848, new artistic fields and styles appeared which rapidly became part of the political arsenal which characterised the ideological opposition between the Italian nationalist movement and the Roman Curia. From the analysis of specific and unusual documental typologies (caricature, painting and fiction), some thematic cores clearly emerge which structure, on both sides, the political rhetoric and the ideological dispute: the notion of people, anticlericalism or anti-republicanism, but above all the
} 
new definition of masculinity and femininity, with the corresponding definition of roles. In this respect, the obsessive attention to feminine corporality and its undesired public explosion, which can be found in both productions, appears to refer to the wider phenomenon of the progressive affirmation of bourgeois society and its system of values (nationalism) and so the tenacious resistance of the clergy aimed at maintaining control over institutions, above all the family, considered to be the true holder of faith and the base of social relations.

Keywords: Risorgimento, women, bourgeois society, Catholic Church, nationalism, cartoon, novel.

\section{RESUM \\ "SI POGUÉS CONVERTIR-ME EN HOME". GÈNERE, POLÍTICA I SOCIETAT: LA RE-DEFINICIÓ D'ALLÒ FEMENÍ EN EL LLARG 48 ITALIÀ}

Durant la revolució italiana i europea de 1948, van aparèixer nous medis o estils artístics que entraren ràpidament a l'arsenal polític que va caracteritzar l'oposició ideològica entre el moviment nacionalista italià i la Cúria romana. Des de l'anàlisi de tipologies documentals específiques e inusuals (caricatura, pintura i ficció fictícia), emergeixen clarament alguns nuclis temàtics que estructuren, en ambdues bandes, la retòrica política i la disputa ideològica: la noció de persones, l'anticlericalisme o l'antirepublicanisme, però sobretot la nova definició de masculinitat i feminitat, amb la diferenciació dels rols corresponents. A aquest respecte, l'atenció obsessiva a la corporeïtat femenina i la seva exposició no desitjada, que es pot trobar en ambdues produccions, pareix referir-se al fenomen més ampli de l'afirmació progressiva de la societat burgesa i el seu sistema de valors (nacionalisme) així com la tenaç resistència del clergat destinat a mantenir el control sobre les institucions, la família abans de res, que considerava el veritable dipòsit de la fe i la base de les relacions socials.

Paraules clau: Gènere, revolució 1948, art, feminitat, Itàlia. 
La revolución de 1848 en la península italiana ha centrado la atención historiográfica en los últimos años, después de haber sido un objeto de investigación soslayado durante mucho tiempo, considerado poco estimulante, o incluso propicio a resbalones retóricos nada convenientes. ${ }^{1}$ La atención renovada que ha despertado la unificación nacional está en deuda con la llamada Nueva historiografía sobre el Risorgimento. A su vez, ésta debe mucho a Alberto Mario Banti, ${ }^{2}$ que ha tenido el mérito de haber presentado una nueva propuesta interpretativa tomada del giro lingüístico, llegado a ltalia unos años más tarde que al norte de Europa. En este nuevo panorama, se ha reservado un amplio espacio para la idea de nación, la antropología, la religión política y, por último, pero no menos importante, para el género. Simonetta Soldani e llaria Porciani, entre otras, han subrayado la importancia de la cesura del siglo XIX en la redefinición del papel

1 Cf. BANTI, Alberto Mario et alii (2011), Atlante culturale del Risorgimento. Lessico del linguaggio politico dal Settecento all'Unità, Bari, Laterza, 2011; y BANTI, Alberto Mario y GINSBORG, Paul (eds.) (2007), Storia d'Italia. Annali 22, Il Risorgimento, Einaudi, Turín.

2 BANTI, Alberto Mario (2011), La nazione del Risorgimento, Einaudi, Turín. 
femenino, en el disciplinamiento, ${ }^{3}$ como escribe la primera historiadora, que las mujeres italianas sufrieron en el momento de la eclosión nacional y, sobre todo, para ese momento. Su enfoque se remite a las enseñanzas de George Mosse, a las herramientas heurísticas de Michel Foucault y a las contribuciones de la historia de género.

La presente contribución retoma ese hilo en un intento de vincular a él tipografías documentales poco explotadas y que casi siempre se tratan de manera exclusiva e independiente. En otras palabras, se pretende analizar cómo las caricaturas, las pinturas y la literatura de ficción han narrado o utilizado lo femenino en los trastornos revolucionarios y nacionales, y tanto en la acción concreta de las mujeres en la escena revolucionaria como en su dimensión simbólica. En este sentido, también pretendemos ampliar el análisis a las producciones de carácter reaccionario vinculadas de diversos modos a la Curia romana y a sus portavoces, un aspecto bastante silenciado en la historiografía reciente.

Como tendré la oportunidad de mostrar, las convergencias y la intertextualidad entre las dos corrientes opuestas no fueron nada infrecuentes, muy al contrario, revelan una repetición clara -y sorprendente- de patrones y estrategias de comunicación, teniendo en cuenta las distancias ideológicas y la búsqueda de objetivos políticos antitéticos. Esta confrontación se centra en la mujer entendida como alma de lo doméstico, el tejido de la familia, y a fin de cuentas como un territorio de enfrentamiento entre el movimiento nacional y la jerarquía eclesiástica en la cuestión más amplia del surgimiento de la sociedad burguesa, que a través de los mitos del nacionalismo y de la nueva moralidad familiar comenzaron a erosionar las bases tradicionales de la devoción y el control del clero. ${ }^{4}$ Por lo tanto, aquí se subrayará cómo se estructuró, en medio de la disputa ideológica, una

3 SOLDANI, Simonetta y PORCIANI, llaria (1999), "Donne e nazione nella rivoluzione italiana del 1848", Passato e Presente, vol. 46 (1999), p. 84; SOLDANI, Simonetta y PORCIANI, llaria (2002), "Italiane! Appartenenza nazionale e cittadinanza negli scritti di donne dell'Ottocento", Genesis, vol. 1, pp. 85-124; y PORCIANI, Ilaria, "Disciplinamento nazionale e modelli domestici nel lungo Ottocento: Germania e Italia a confronto", en BA. Como tendré la oportunidad de ilustrar las convergencias, la intertextualidad entre las dos partes opuestas será todo menos rara y señalará una repetición evidente y repetitiva de patrones y estrategias de comunicación, teniendo en cuenta las distancias ideológicas y los objetivos políticos antitéticos.

4 Cf. ISNENGHI, Mario y CECCHINATO, Eva (eds.) (2008), "Fare I'Italia: unità e disunità nel Risorgimento", en Gli italiani in guerra. Conflitti, identità, memorie dal Risorgimento ai nostri giorni, vol. I, Utet, Turín. 
fuerte convergencia retórica entre los contendientes que certifica la existencia de un discurso efectivo, de una metodología narrativa considerada unánimemente ganadora, inaugurada primero por los actores revolucionarios y luego adoptada por oradores eclesiásticos y reaccionarios. Mediante el uso de la idea de la mujer, se libró la batalla por la imposición de una determinada opción ideológica y la afirmación del sistema de valores burgués, entre cuyos puntos clave figuraban la familia y el papel exclusivamente doméstico reservado a las mujeres.

\section{LA EBRIEDAD EFIMERA DE LAS BARRICADAS: LA MEMORIALÍSTICA}

Un elemento que recorre transversalmente todas las obras de memorias escritas después del 48 por actores revolucionarios más o menos prominentes es la atmósfera de concordia y unanimidad momentáneas que acompañaron a los trastornos políticos en toda la Península, desde el Milán de los Cinco Días a la Roma republicana de 1849. Como escribe Giovanni Visconti Venosta, observador participante en la revolución milanesa

Dappertutto era la stessa cosa; come in una polveriera dove si fosse dato fuoco a una miccia nel tempo stesso, in ogni città, in ogni borgata, in ogni villaggio, ognuno a suo modo aveva fatto la sua rivoluzione, quasi vi fosse stata un'intesa, e con gli stessi caratteri di concordia, di entusiasmo, e talora di imprevidenza generosa e ingenua. ${ }^{5}$

En este ejemplo queda claro que se invoca a la patria mediante un llamamiento retórico a la unidad, la suspensión de altercados y la superación temporal de las barreras sociales y culturales tradicionales. Incluso aquellos que, por razones de edad, religión o género, estaban tradicionalmente excluidos de la vida pública encontraron su espacio en la celebración unánime del cuerpo de la nación. También les ocurrió a las mujeres en armas, desde Rosa Verza hasta Domenica Luigia Sassi, que vivieron un momento contradictorio e inesperado de protagonismo entre los silbidos de las balas en las barricadas. El caso de Sassi es sintomático: casada y de 24 años de edad, "fu la prima a fare le barricate nel suo quartiere, strappata di mano una pistola ad un soldato, intimò ad altri cinque d'arrendersi, i quali presi, furono consegnati nella caserma dei finanzieri [...]. Vestitasi da vomo, al

5 VISCONTI VENOSTA, Giovanni (1904), Ricordi di gioventù. Cose vedute o sapute 18471860, Tip. Ed. L. F. Cogliati, Milán, 1904, pp. $115-116$. 
borgo di S. Croce arrestò tre guardie di polizia" y "fattasi conduttrice di circa 100 vomini, insegui una mano di fanti e di cavalieri, e questo sotto una pioggia di palle", hasta que por fin sostuvo "una lunga fucilata contro i croati". ${ }^{6}$

Esta mujer, la del 48 italiano, aparece dividida entre su papel de madre/ hermana/esposa y las ansias políticas y de autonomía personal que aquellos primeros espacios de libertad parecían propiciar. Así, la joven romana Colomba Antonietti, "già avvinta con nodi maritali, soccorreva lo sposo che a riparar le breccie era andato, e con ardore s'adoprava là dove più ferveva il pericolo, lasciando incerto il riguardante se in lei potesse più l'amore che al suo sposo l'arvinceva o quello fortissimo che alla sua patria la lega$v a^{\prime \prime}$. Dividida entre la vocación pública y los deberes conyugales, seguía a su marido "in tutte le fazioni di guerra, a cui per l'Italia s'avventurava, dividendo con lui fatiche e pericoli". En el fragor de la batalla mantuvo una calma inusual, "serena, tranquilla, impavida ella rimaneva al suo posto, ed ogni volta che i suoi sguardi s'incontravano in quelli del suo sposo [...] una fiamma di contento parea salirle al viso quasi inorgoglito avesse di quella sua carita di patria. Alcuni soldati caddero in quella morti a suoi piedi, né per le nuove istanze fattele ella volle ritirarsi; vi fu un momento anzi in cui alla fe' un passo verso il marito per fornirlo degli strumenti che aveva addimandati, e una palla di cannone la percosse adempiente quell'atto di amore coniugale". La conducta ejemplar y patriótica de esta mujer culminó plenamente con su dramática despedida del mundo: hincada de rodillas, "levò le mani e gli occhi al cielo e spirò dopo un minuto gridando 'Viva I'Italia'. I suoi leggiadri lineamenti si copersero del pallore della morte, ma il sorriso non si scompagnò dalle sue labbra che anche in quell'eterno silenzio esprimer pareano l'amore e la fede, che collegata l'aveano in vita alla sua famiglia e alla sua patria". En el cortejo fúnebre que se improvisó en su honor en Roma, "il popolo trasse in folla dietro al feretro coperto di bianche rose, simbolo del candore di lei spenta sì crudelmente nel fiore della giovinezza" ${ }^{\text {? }}$

6 CATTANEO, Carlo (1850-51), Archivio triennale delle cose d'Italia dall'avvenimento di Pio IX all'abbandono di Venezia, Tipografia Elvetica, Capolago, vol. I, p. 396.

7 RUSCONI, Carlo (1850), La Repubblica romana (del 1849), Editore Cassone, Turín, vol. II, pp. 158-159. Otro caso famoso es el de Battistoni-Sassi, también una mujer en armas, que treinta años después de los acontecimientos seguía sorprendiendo a Giuseppe Bollini. El relato retoma algunos de los temas centrales sobre el papel de las mujeres en el Risorgimento, su raro- protagonismo y las formas en que se expresó su voluntad: "poco dopo sortì dalla stessa casa n. 23 una donna (brunetta) vestita da vomo [...] che andò a sedersi accanto all'vomo che 
Con mucha más frecuencia, no obstante, el papel reservado al género femenino era más tranquilo y se representaba en la sombra, desde la confección de cartuchos hasta los trabajos de costura. ${ }^{8}$ Pasado el primer entusiasmo, en los meses siguientes los espíritus más fogosos y conflictivos tuvieron que replegarse a la plácida vida cotidiana. Se acabó la efervescencia del estallido revolucionario, en que todos esos nuevos actores habían sido momentáneamente lanzados al centro de la arena política, a las calles y barricadas. ${ }^{9}$ En Venecia, la petición de un grupo de mujeres de ser admitidas en la Guardia Cívica, símbolo y emblema de la identidad política y militar, se consideró inapropiada y fue rechazada, mientras que en Roma la participación femenina en la guerra patria se recondujo y se restringió a la confección de banderas, a la recaudación de fondos y a servicios más femeninos, como la asistencia a los heridos y enfermos. ${ }^{10}$ De hecho, los recientes y fugaces momentos de liberación y licencia hicieron que las mujeres constatasen y padecieran más su condición. En Como, la republicana Luisa De Orchi, apasionada seguidora de Garibaldi, que pintó y vendió acuarelas para financiar las empresas del héroe, al escribir a una amiga le confesaba: "Se potessi diventar vomo, sarei soldato, così mi tocca d'ingojare il calice amaro delle dure abnegazioni, cui donna è condannata" . ${ }^{11}$ Eso no quita que, durante ese momento de apogeo nacional, se abriesen a las mujeres, siquiera momentáneamente, espacios temporales de discurso y acción y, en cualquier caso, se les reconociera un papel visible en las liturgias civiles y las ocasiones solemnes, así como un lugar en la celebración

la stava aspettando. Di un tratto si senti gridare il solito 'armi da fuoco in Borgo S. Croce'. La brunetta, che seppi poi essere la Sassi, scattò in piedi, tolse il fucile di mano al suo compagno e passò ridendo nella barricata di S. Croce. La vidi poi sopra un ballatoio di legno dirigere colpi di fucile sul bastione" (citado en BORTOLOTTI, Michela ("Le piazze e le barricate nel Quarantotto",en Fare I'Italia, p. 504).

8 VISCONTI VENOSTA, Ricordi, p. 113

9 Sin embargo, poco después, "i nobili tornarono a sentirsi diversi dai cittadini, i ricchi dai poveri, gli aristocratici della moda dagli vomini tagliati alla buona; ricomparvero le livree e gli stemmi sulle carrozze, la sostenutezza coi dipendenti; i titoli". También los judíos, acogidos por el fervor revolucionario en la celebración de la familia patria y en los abrazos de marzo, experimentarían de nuevo la hostilidad popular tras su incorporación a las filas de la Guardia Cívica. AMBROSOLI, Luigi (ed.) (1969), La insurrezione milanese del marzo 1848, Ricciardi, Milán-Nápoles, pp. 103-104.

10 FRANCIA, Enrico (2012), 1848: la rivoluzione del Risorgimento, II Mulino, Bolonia, pp. 283 296.

11 BORTOLOTTI, Le piazze e le barricate nel Quarantotto, p. 508. 
de la cuerpo de la nación junto con otros actores generalmente excluidos de la vida pública. ${ }^{12}$ En los desfiles, en los Te Deum y en las procesiones, las mujeres no sólo intervinieron como espectadoras, sino que formaron junto a los representantes de las instituciones y participaron activamente en las mismas actividades públicas que los hombres. Esta presencia visible de las mujeres fue considerada legítima, e incluso necesaria, por algunos líderes patriotas. La inclusión en la vida pública de quienes normalmente eran ajenos a ella confirmaba y reforzaba la tendencia a la unanimidad de la vida política del Risorgimento, al menos en sus fases revolucionarias. La legitimidad de un papel público para las mujeres se inscribe plenamente en ese discurso nacional-patriótico "che attribuisce alla rinascita della nazione un carattere morale e civile ancora che politico" ${ }^{13}$ que llama a toda la comunidad a participar activamente..., pero que al mismo tiempo define rígidamente los roles de género. ${ }^{14}$ Por lo tanto, a las mujeres se les concedió un papel patriótico que desempeñaron principal, si no exclusivamente, en el ámbito doméstico, como madres, esposas o hermanas: ${ }^{15}$ "L'Angelo della Famiglia è la Donna. Madre, sposa, sorella, la Donna è la carezza della vita" ${ }^{16}$ Su aparición en la escena debía basarse en estos valores y le-

12 FRUCl, Gian Luca (2006), "Cittadine senza cittadinanza. La mobilitazione femminile nei plebisciti del Risorgimento (1848-1870)", Genesis, vol. 2, pp. 21-55; y FRUCl, Gian Luca (2007), "Il sacramento dell'unità nazionale. Linguaggi, iconografia e pratiche dei plebisciti risorgimentali (1848-1870)", en BANTI y GINSBORG (eds.), Storia d'Italia. Annali 22, pp. 567-605.

13 Citado en FRANCIA, 1848: la rivoluzione del Risorgimento, p. 284.

14 BIZZOCCHI, Roberto (2007), "Una nuova morale per la donna e per la famiglia", en BANTI y GINSBORG (eds.), Storia d'Italia. Annali 22, pp. 87 y ss.; y BANTI, Alberto Mario (2005), L'onore della nazione. Identità sessuali e violenza nel nazionalismo europeo dal XVIII secolo alla Grande Guerra, Einaudi, Turín,.

15 Es el caso, por ejemplo, de las mujeres de Dolo, que con motivo de la organización del plebiscito de anexión de 1866, presentaron sus solicitudes de participación basando la legalidad de su discurso en haber compartido emocionalmente el destino de sus padres, hijos y hermanos: "Le donne del distretto di Dolo che divisero i dolori e le umiliazioni dei padri, dei fratelli, degli sposi, dei figli durante l'austriaca tirannia, vollero pure partecipare della gioia del sesso maschile chiamato alla fortuna di dichiarare la sua volontà" (Aviso a la población de la comisión dfemenina por el plebiscito de Dolo, Venecia) también: "Anche noi donne italiane abbiamo diritto e dovere di esprimere il nostro voto [...]. Abbiamo diviso i dolori, i tormenti, le umiliazioni dei nostri padri, dei fratelli, degli sposi dei figli, abbiamo pianto con essi e forse più di essi [...] perché oggi non prenderemmo parte attiva alla loro gioia?". En MINISTERIO (1968), Gli Archivi dei regi commissari nelle province del Veneto e di Mantova 1866, II, Documenti, Ministero dell'Interno, Roma, p. 138.

16 MAZZINI, Giuseppe (1860), Doveri dell'uomo, [s. e.], Londres [Lugano], p. 66. 
gitimarse por ellos, sin subvertirlos desde un punto de vista político y social. Así, en el periódico romano La donna italiana se pedía a las lectoras que animaran a sus padres, hijos y consortes "a volare sui campi di battaglia" y "a cogliervi o la palma del martirio o il lauro della vittoria". ${ }^{17}$

Para corroborar el poder evocador de esta llamada, se proponía el modelo ejemplar de una madre de Brescia que había exhortado a sus hijos de este modo: "salvate la patria, e non tornate nelle mie braccia che morti e vincitori. ${ }^{18}$ El surgimiento de protagonismos femeninos como los de Caterina Franceschi Ferrucci y Cristina di Belgioioso aparece como diametralmente opuesto. En toda la Península, un gran número de mujeres se alzaron en armas y decidieron participar, como sus esposos y hermanos, en la virilidad guerrera y patriótica, y a pesar de ello las mismas heroínas combatientes vivieron con incomodidad o disgusto su condición de mujeres en armas, hasta el punto de elegir vestirse de hombres para participar en las acciones bélicas. ${ }^{19}$ Incluso las mujeres a las que no se les permitió este tipo de protagonismo expresaron esa desazón respecto a su condición femenina. Por ejemplo, la veneciana Maddalena Montalban Comello confesaba dolorosamente a Garibaldi su impotencia, porque "la natura mi fece il torto di farmi donna, perché il nostro sesso è pieno di schiavitü". ${ }^{20}$

La necesidad de disfrazarse de hombre o de externalizar el rechazo a la propia condición de género manifiestan la conciencia de que la rígida dicotomía de los roles sexuales ahogaba el potencial femenino, en un disciplinamiento que llevó a "avvertire alle donne [...] un senso di ingiustizia per

17 DE LONGIS, Rosanna (2002), "La donna italiana. Un giornale del 1848", Genesis, vol. 1, p. 262.

18 DE LONGIS, "La donna italiana. Un giornale del 1848", p. 289.

19 Así ocurrió con Domenica Luigia Sassi, piamontesa de veinticuatro años que "fu la prima a fare le barricate nel suo quartiere [...] vestitasi da uomo, al borgo si S. Croce arrestò tre guardie di polizia" e "fattasi conduttrice di circa 100 uomini, inseguì una mano di fanti e cavalieri, e questo sotto una pioggia di palle [...] e sostenne, unita a vari pompieri, una lunga fucilata contro i croati" (Archivio triennale, III, p. 396). Se pueden hallar otros rastros -no muchos, a decir verdad- en monumentos patrióticos: el protagonismo guerrero de Rosa Verza, que murió como mártir, asesinada por los disparos de cañones de los austriacos, o el heroísmo, dividido entre el deber conyugal y la exposición política y militar, de Colomba Antonietti. Véanse respectivamente MONTANELLI, Giuseppe (1853), Memorie sull'Italia e specialmente sulla Toscana dal 1814 al 1850, Società Editrice Italiana, Turín, vol, II, p. 439; y RUSCONI, La repubblica romana, pp. 157-159.

20 FRANCIA, 1848: la rivoluzione del Risorgimento, p. 293. 
l'esclusione [...]. Di qui il paradosso [...] di percepirsi come cittadine senza cittadinanza, costantemente in bilico fra comunità egualitaria immaginata e aspirazioni emancipazioniste". ${ }^{21}$

\section{El 48 en IMÁGeNeS: eNTRE GÉNERO Y POLÍTICA}

Ahora bien, el largo 48 italiano y su relato no fueron prerrogativa única de las memorias; muy al contrario, tanto la caricatura, un formato que nace y se expande en este momento, ${ }^{22}$ como la pintura $^{23}$ dedicaron, a pesar de sus importantes diferencias técnicas e iconográficas, una atención especial a los trastornos políticos que tenían lugar y al papel desempeñado, concreta o simbólicamente, por las mujeres. Aquí el análisis se centra en la producción de los soldados-pintores, unas figuras decisivas, porque combinaron la pintura en el campo de batalla con el activismo democrático y nacionalista, concretamente en cuatro publicaciones periódicas de caricaturas de particular interés. A excepción del milanés Lo Spirito Folletto, se trata de dos periódicos satíricos ilustrados romanos que establecen entre sí un constante juego de espejos, con alusiones y respuestas polémicas y políticas: Don Pirlone, ${ }^{24}$ revista democrática que acompañó y celebró la efímera República Romana de 1849, y su contrapunto reaccionario, la Grande Riunione, ${ }^{25}$ una obra anónima y colectiva que nació con el objetivo declarado de refutar y criticar al periódico satírico republicano y, por ende, la obra de la revolución romana. Por último, se tendrá en cuenta Don Pirlone a Roma, ${ }^{26}$ una obra colectiva publicada en varios volúmenes

21 FRUCl, "Cittadine senza cittadinanza", p. 23.

22 MORACHIOLI, Sandro (2013), L'Italia alla rovescia. Ricerche sulla caricatura giornalistica tra il 1848 e l'Unità, Edizioni della Normale, Pisa; AAVV (1998), Le rivoluzioni del 1848. L'Europa delle immagini:caricatura e illustrazione tra storia e arte, Associazione Torino Ccittà Ccapitale Europea, Turín; MAGGIO SERRA, Rosanna (2005) "Disegno, grafica e fotografia tra lotta ideologica, comunicazione mediatica e nuovi saperi", en HANSMANN, Martina (ed.), Pittura italiana dell'Ottocento, Marsilio, Venecia, 2005, pp. 349-366; y MAGGIO SERRA, Rosanna (1980), "La naissance de la caricature de presse en Italie et le journal turinois 'll Fischietto'", Histoire et Critique des arts, vol. 13-14, pp. 135-158.

23 MARINI CLARELLI, Maria Vittoria, SISI Carlo y MAZZOCCA, Fernando (eds.) (2008), L'Ottocento. Da Canova al Quarto stato, Skira, Milán; y MAZZOCCA, Fernando (ed.) (2010), 1861. I pittori del Risorgimento, Skira, Milán.

24 Don Pirlone: giornale di caricature politiche, Roma, 1848-1849.

25 Grande riunione tenuta nella sala dell'ex Circolo popolare in Roma, Roma, 1849.

26 PINTO, Michelangelo (1853), Don Pirlone a Roma. Memorie di un italiano dal 1 settembre 1848 al 31 dicembre 1850, Tipografia del Progresso, Turín, vol. I. 
en Turín en los años inmediata posteriores al colapso del 48 italiano y que, al completar los propósitos de su antecesor romano, se presenta como una interpretación general, una colección de juicios sobre los acontecimientos políticos romanos e italianos, así como una respuesta democrática a las invectivas clericales y antirrepublicanas de la Grande Riunione.

A primera vista, la producción caricaturesca del 48 y su retrospectiva parecen ignorar por completo lo femenino: son pocas las ilustraciones donde aparecen las mujeres, que muy raramente constituyen el objeto principal del discurso. Sin embargo, existen algunas excepciones, tanto más significativas cuanto que se refieren a la condición de las mujeres en el Risorgimento y al papel que se les reservó: obsérvese por ejemplo la ilustración de Don Pirlone a Roma titulada "Una generosa vendetta":

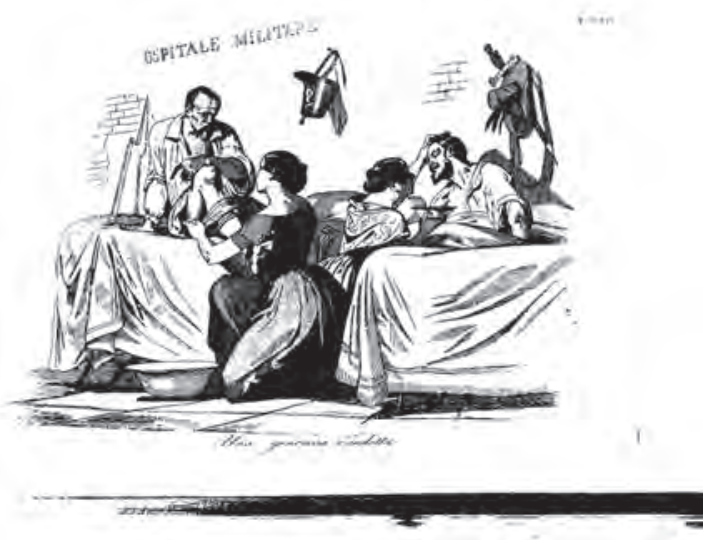

Fig. 1.

Estamos ante un juego continuo de alusiones mutuas entre las dos publicaciones posteriores al 48 , y por ellas el grabado puede interpretarse como una respuesta a la calificación nada amable que la Grande Riunione había reservado para las organizadoras ${ }^{27}$-entre ellas, una admiradora entusias-

27 No era un caso aislado. Baste con observar la sabrosa ilustración que la Grande Riunione dedicó a los principales actores revolucionarios de la Roma republicana (entre los que destacan los triunviros Mazzini, Armellini y Saffi), retratos como de costumbre caricaturescos, con rasgos zoomórficos, entre los que destaca la principal organizadora del servicio de ambulancias, la famosa patriota Cristina Trivulzio di Belgioioso: ella y sus asociados son retratados, en una alusión misógina no demasiado refinada, como gansos. 
ta de Garibaldi, la americana Margaret Fuller- del comité de gestión de las ambulancias. Léase el diálogo que sostienen Cassandrino, un personaje popular de orientación reaccionaria, y su interlocutor Apollonio:

APOL. Ma per i Feriti v'erano ampli e moltiplici Ospedali con medici, Chirurghi, e Farmacisti, e Donne

CAS. Eh! Capisco: le sorelle della carità...

APOL. Carità? Non erano Sorelle, no; erano in grandissima parte, non tutte, mogli da maritarsi a chi le voleva, senza testimoni, e senza curati. Femine dissolute, la cui Biografia dovrebbe scriversi dal Casti; la cui fama le circonda costante, come un aureola, come un nembo, che è il distintivo dei servi di Dio, per esse, è una riputazione da Lupanara, che si odora da lontano, come quel Cavallo che da lunge odora la Guerra. Pio IX che in Gaeta sapeva le più intime particolarità di questi Satanici Ospedali [...] scriveva agli arcivescovi e Vescovi d'italia in queste precise tremende parole: "Spesse volte gli stessi sciagurati infermi, privi affatto d'ogni soccorso religioso, nell'istante supremo della morte furono costretti ad esalare l'ultimo sospiro in mezzo alle inique seduzioni d'una meretrice sfacciata". So, e con certezza io so, che queste parole abbiano fatto effetto d'una spina di pesce in gola a molte signore, che si erano recate dai Malati Militari; ma direi loro che fu improvvido assai quell'andare ove dominava una Belgioioso, una...una...

CAS: Non mormorate fra i denti. Dite apertis verbis.

APOL: Non posso. Perché sono nomi di amiche vostre. Una è certa vedova maritata vecchia matta..

CAS: Ho capito. Ho capito. Mi pare l'ultimo giorno della Fiera di Sinigaglia: quello ch'è fatto, è fatto.

APOL: L'altra è una bella Matrona Girovaga. Non vi dico fosse impudica; no, ma..è certo, che procurava ai malati Libri disonesti, e anticattolici [...] V'era qualche comica, che arrendevole si prestava a carezze indecenti. Che vi si fossero introdotte delle Donne da prezzo è noto pur troppo! ${ }^{28}$

Es bastante probable que la "vedova maritata vecchia matta" fuese Fuller, corresponsal del periódico neoyorquino Tribune y casada hacía poco con el marqués Giovanni Angelo Ossoli. Resulta evidente que el texto está re- 
pleto de dobles sentidos y de referencias sexuales veladas o explícitas, así como que éstas son los vectores principales del mensaje, al mismo tiempo político y social: el libertinaje revolucionario se presenta como el mayor obstáculo para la convivencia promiscua de hombres y mujeres. La ilustración de Masutti parece revisar, aunque no desmentir, el sobrentendido. En realidad, y a pesar de ser enemigos, los militares franceses "indistintamente confortati dalle stesse attenzioni", 29 son púdicamente vendados y curados por las voluntarias organizadas por Cristina Belgioioso, una tarea que, diga lo que diga la publicación reaccionaria, se encuentra entre las pocas socialmente aceptadas durante el Risorgimento. Aunque sea a duras penas. Como ya se ha dicho, se reserva a las mujeres la gestión más segura del ámbito doméstico, desde el papel de engendradora al de educadora en los valores nacionales, así como, a lo sumo, las labores de costura de uniformes y banderas o de confección de cartuchos, tareas rigurosamente confinadas a la oscuridad del hogar. Otros protagonismos -excepciones aparte- estaban severamente prohibidos o se mirababn con malos ojos, como demuestran las ilustraciones irónicas y machistas aparecidas en 1848 en Lo Spirito Folletto sobre la Guardia Civica Femminile, un cuerpo que, de todos modos, no llegó a organizarse.

Aquí, al activarse una analogía poco sorprendente con el lenguaje reaccionario de la Grande Riunione, el rasgo humorístico se vincula a lo sexual, a la fragilidad emocional de las mujeres, al riesgo de promiscuidad y, en última instancia, a la incompatibilidad congénita e irremediable de lo femenino con la esfera pública. Es elocuente la ilustración maliciosamente titulada "II Rapporto" (Figura 2), que representa a una guardia cívica en pose de saludo militar a su superior, la cual yace en un diván con mirada lánguida, el pecho entreabierto y un ramo de flores en la mano; un sombrero masculino sobre el lecho revela la presencia de un hombre apenas oculto. El diálogo inserto al pie como subtítulo completa la poco velada alusión:

Cittadina generale, hanno deciso per l'unione immediata!.. Vi era già predisposta... 


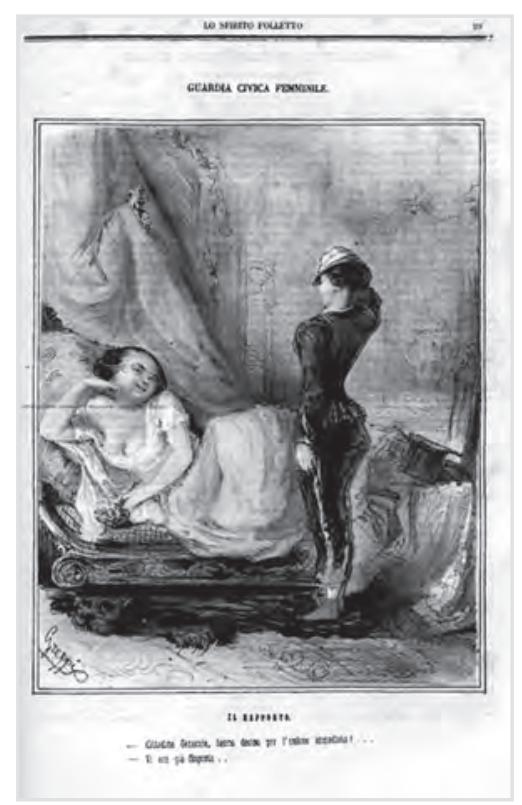

Fig. 2.

La ironía misógina de la ilustración resulta aún más estridente si se considera la situación política del Milán de aquel tiempo, ferozmente dividido por la elección entre la unión inmediata al Piamonte o el aplazamiento de la decisión hasta después de la guerra (por cierto, la posición que sostuvo ese periódico), así como la brecha entre el Gobierno provisional y una gran parte de la opinión pública de la ciudad. ${ }^{30}$ Para confirmar el tono misógino y segregacionista de los dibujos del periódico milanés, unos días antes se había publicado otra ilustración (Figura 3) -de las cinco en total que componen la serie sobre la Guardia Civica Femminile- que representa a las cívicas enfundadas en uniformes especialmente estrechos -para subrayar deliberadamente las formas femeninas-e intentando seguir las órdenes de una superior, seguramente en el contexto de un desfile o una parada.

30 CATTANEO, Carlo (1849), Dell'insurrezione di Milano e della successiva guerra, Tipografia della Svizzera Italiana, Lugano, pp. 107 y ss. 


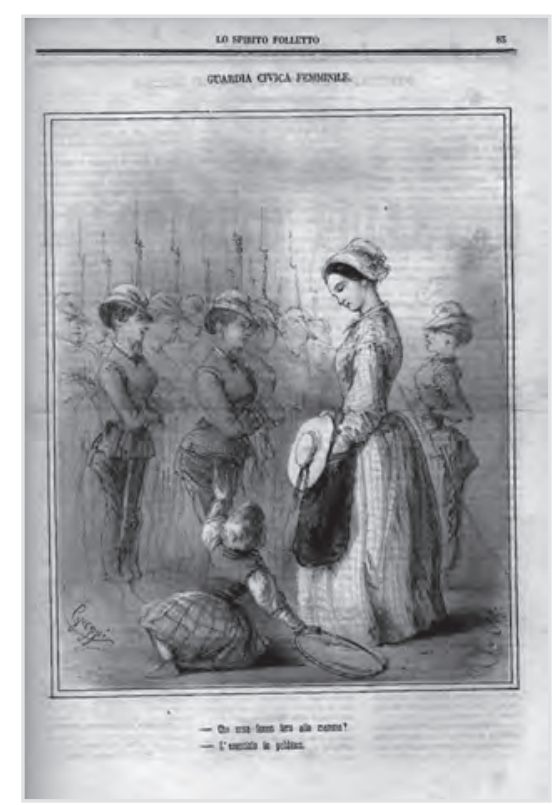

Fig. 3.

Una niña le pregunta a su nodriza, esta sí, vestida casta y correctamente, "che cosa fanno fare alla mamma?". La respuesta, que redondea el significado del grabado, contiene y al mismo tiempo muestra la peligrosidad del momento: "L'esercizio in pubblico", responde plácidamente la mujer. Como en "Il Rapporto", se subraya la dimensión antisocial de la presencia pública visible de las mujeres, pero en este caso no se invoca el amor erótico -aun así, presente en el resaltado de la sinuosidad de los cuerpos-, sino los aspectos familiares, resaltando los riesgos de la promiscuidad y del protagonismo femenino en el ámbito público y, como sucede aquí, en el privado. Como explicaré más adelante, este énfasis es sustancial.

De todos modos, la mujer, entendida como asunto o tema ilustrativo, no se limita a esta finalidad. Más bien, y como exponente de las características de los diversos aspectos de lo femenino (debilidad, vanidad, falta de autocontrol, ausencia de autonomía), las mujeres se convierten en actrices que se mueven en una escenografía enmarcada en el canon nacional-patriótico y que tiene el cometido de impulsar y conservar el honor de Italia. Por ejemplo, en "Oltraggio e punizzione" (Figura 4), de Massutti, aparecida en Don Pirlone a Roma, la presencia de una mujer, indefensa y molesta ante la imagen salvaje de un invasor con aspecto diabólico, ofrece una oportunidad para el rescate del honor privado y del nacional. El grabado se libera 
esta vez del componente alegórico, residual, en beneficio de un discurso descriptivo que obtiene su fuerza del sistema narrativo de la referencia, de la alusión evidente a la tradición de las Vísperas Sicilianas. ${ }^{31}$ Aparece así en escena la masa popular, como héroe impostado. Ante la insoportable visión de las

vittime quotidiane [inmoladas] alla vendetta dei barbari, e la libidine soldatesca invidiava ai cittadini più che la vita, attentando all'onor delle donne con inaudita violenza. Ma il braccio del popolano fece più d'una volta giustizia della insana licenza, e nel sangue dell'osceno croato lavò sovente l'oltraggio. ${ }^{32}$

El valore italiano, como lo llama el tándem en el grabado ilustrativo, surge aquí en defensa del honor, tanto de las mujeres como, en respuesta explícita a la acusación de afeminamiento, de los hombres en el campo de batalla.

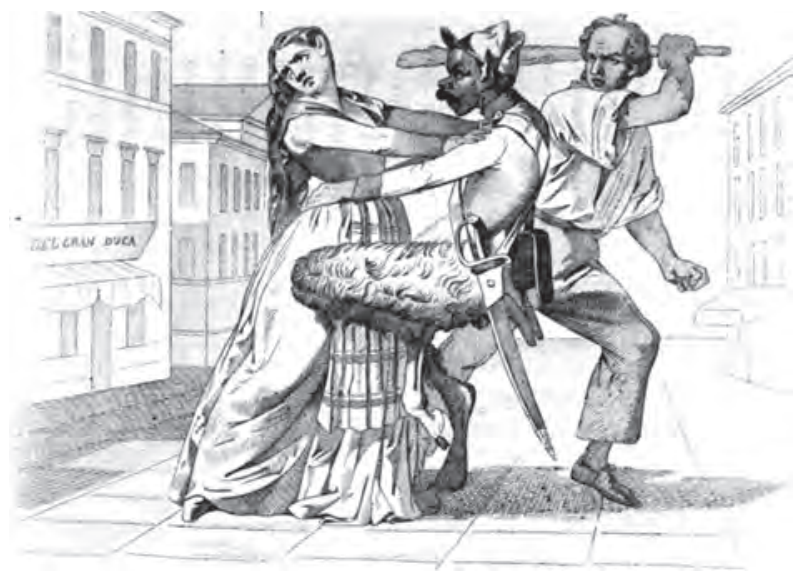

Fig. 4.

Al pasar de la caricatura al ámbito pictórico, el papel que representa el tema femenino en el esquema figurativo de las propuestas artísticas de los pintores-soldados se sitúa en línea de continuidad de ideas con lo que se ha visto en la ilustración satírica. Bastará observar la Trasteverina colpita da una bomba, de Gerolamo Induno (Figura 5) y el famoso cuadro de Odoardo Borrani Le Cucitrici (Figura 6).

31 MAZZOCCA, Fernando (1982), Invito a Francesco Hayez, Rusconi, Milán.

32 PINTO, Don Pirlone a Roma, vol. III, p. 109. 
Se trata de representaciones fuertemente imbuidas de sentido patriótico, donde el sujeto retratado es, justamente, femenino, y en las que el papel discursivo en/de la femineidad surge con total claridad. En el primer caso, la sorpresa y el horror desatados por la crudeza del cuadro residen tanto en el registro realista de Induno como, sobre todo, en la identidad de género de la víctima. Estamos, en suma, ante la representación del cuerpo sin vida de una joven mujer romana víctima de una bomba francesa, a pesar de que se mantuviera a cobijo, en la cocina de su propia casa. ${ }^{33}$ La efímera experiencia republicana había tenido lugar hacía poco, así que la presentación del cuadro en Brera logró un gran efecto, que impactó en la crítica y obtuvo -aspecto éste del todo relevante- un gran éxito de público. ${ }^{34}$

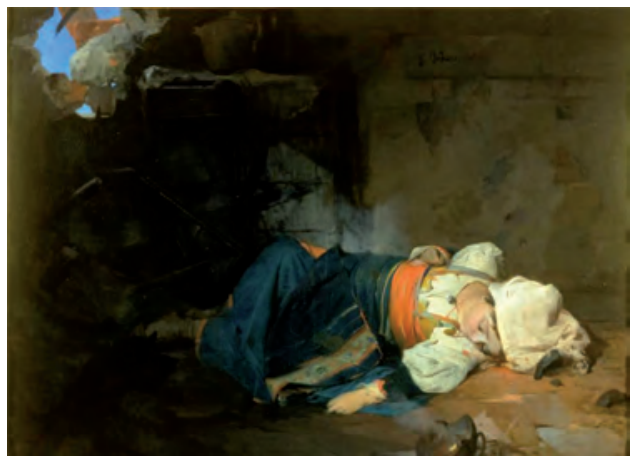

Fig. 5.

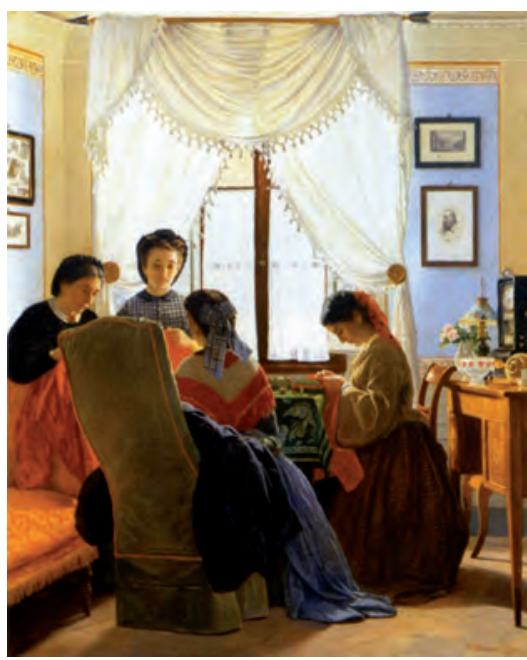

Fig. 6.

33 En palabras de Giuseppe Rovani, "Nella sua semplicità [la pintura] rappresenta un grande momento della vita contemporanea e l'immaginazione, per quell'unica figura, si vede innanzi la vasta scena delle solenni sventure dell'eterna città assediata" (ROVANI, Giuseppe (1860), "Esposizione di Belle Arti nel palazzo nazionale di Brera", Gazzetta di Milano, 259, 18 de septiembre de 1860. Es del mismo parecer la citada reseña publicada en La Società, que describe la imagen como un "episodio del glorioso assedio fatto dalle armi francesi a Roma [...] una bomba penetra nella stanza di una povera fanciulla e questa sta rovesciata in sul terreno immersa nel proprio sangue. II soggetto benissimo eseguito fa raccapricciare l'osservatore e deplorare le umane miserie" ("L'esposizione di Belle Arti", La Società, p. 53). Véase también la crítica del académico Antonio Zoncada, que volvió sobre el tema-la muchacha-, por bien 
Como escribió el crítico de arte Rovani, el de Induno era "un quadro che ti si imprime nella memoria e ti comanda la meditazione intorno ai fatti più tremendi della vita pubblica" 35 y que quedaba grabado tanto por su fuerza expresiva, su brutalidad y su "raccapriccio" (horror), , 36 como por el franco reconocimiento artístico de la contribución de todo el pueblo, mujeres incluidas, en la defensa de la Ciudad Eterna; de la puesta en escena, en fin, de los postergados y los olvidados. El éxito de público y el gran eco de la Trasteverina fue refrendado por la crítica oficial que publicó el periódico gubernamental Gazzetta Ufficiale di Milano y por los dictámenes de los expertos del ramo, ${ }^{37}$ como Carlo Tenca en las páginas de Crepuscolo. ${ }^{38}$ La eficacia del mensaje político -la brutalidad de los sitiadores y la justicia de la causa republicana y nacional- se aseguró mediante el recurso a la congénita debilidad femenina, a la mujer como depositaria del honor y garante de la descendencia patria; por lo demás, la juventud y la apelación a la tradición étnica romana incrementaban más si cabe la carga evocadora y emocional de la imagen. La de Induno es, en esencia, una construcción comunicativa que se mueve entre el plano racional -estilístico, técnico, temático, político...- y otro semiconsciente y atávico -lo que Ginsborg y Banti llaman el "spazio delle figure profonde" $-{ }^{39}$ de forma que se establece un vínculo entre la elección estilística y la temático-emotiva que garantiza la atención y el éxito del cuadro.

ejecutado, armónico y expresivo (ZONCADA, Antonio (1850), "Appendice. Esposizione di Belle Arti nel palazzo di Brera IV", Gazzetta Ufficiale di Milano, vol. 264, 21 de septiembre de 1850, p. 1.231). Cf. REGONELLI, Silvia (2006), "Risorgimento intimo. La trasteverina uccisa da una bomba di Gerolamo Induno", L'uomo nero. Materiali per una storia delle arti della modernità, III, vol. 4-5, pp. 357-373.

34 MAZZOCCA, 1861. I pittori del Risorgimento, p. 114.

35 ROVANI, Giuseppe (1850), Una parola sulla pubblica esposizione di Belle Arti, 1850, p. 293.

36 "L'Esposizione di Belle Arti del 1850", en La Società. Giornale di Letteratura, Arte, e Scienze Sociali, I, vol. 12, 8 de septiembre de 1850, p. 53.

37 Citado en MAZZOCCA, 1861. I pittori del Risorgimento, p. 114.

38 TENCA, Carlo (1850), "Esposizione di Belle Arti nel Palazzo di Brera. III", II Crepuscolo. Rivista Settimanale di Scienze, Lettere, Arti, Industria e Commercio, I, vol. 33, 22 de septiembre de 1850; citado en MAZZOCCA, 1861. I pittori del Risorgimento, p. 114.

39 GINSBORG, Paul y BANTI, Alberto Maria (2007), "Per una nuova storia del Risorgimento", en BANTI y GINSBORG (eds.), Storia d'Italia. Annali 22, pp. XXIII-XLI. 
Si en la Trasteverina el discurso sobre la femineidad se contrapone a un segundo nivel de lectura, más denso y de apreciación menos inmediata, se vuelve más didáctico en la pintura de Borrani: aquí, los sujetos femeninos se ven limitados a colaborar con la causa patriótica cosiendo banderas o camisas rojas en el seno de la plácida y segura calma doméstica, mientras a su alrededor otros elementos del mobiliario -la estampa de Garibaldi en la pared o la enseña tricolor- proporcionan indicaciones precisas para la interpretación. Es, en suma, el reconocimiento del papel femenino en las batallas, o quizá sería mejor decir para las batallas, del Risorgimento. Los hechos de armas y el protagonismo de Cristina Belgioioso y sus compañeras -aceptadas, aunque sea a disgusto y tan solo como excepcionesestán, en realidad, a años luz de distancia, y se permite la participación del universo femenino en el gran drama nacional solo a través de tareas honorables que se lleven a cabo en la penumbra del hogar. Aunque el panorama aparezca muy fragmentado y haya que rehuir cualquier generalización forzada, la donna nuova invocada, esperada (más probablemente, temida) que se plasma sobre el ideal de la virilidad masculina y difunden algunos periódicos patrióticos, parece más una abstracción literaria que el registro de una realidad efectiva, de forma que el protagonismo femenino adquiere un carácter de excepción.

\section{LA LITERATURA DE FICCIÓN}

En paralelo al resurgimiento del interés por la historia del Risorgimento, en los últimos veinte años, la novela histórica también ha entrado en el debate historiográfico, por un lado suscitando encendidas disputas metodológicas y por el otro alcanzando por diversas razones la categoría de fuente histórica creíble. ${ }^{40}$ De forma análoga a lo que se ha visto en la ilustración, también la producción literaria contribuyó de manera significativa a la lucha ideológica que se libraba aquellos años y estableció una asonancia

40 Se trata de un asunto complejo y muy debatido. Aquí me limito a señalar a GAY, Peter (2004), Nello specchio del romanzo. Dickens, Flaubert, Thomas Mann, Carocci, Roma; GAY, Peter (2002), Schnitzler's Century: the making of middle-class culture, Norton \& Co, Nueva York; HARLAN, David (ed.) (2005), Rethinking History, vol. 2-3 (2005), con textos de diversos autores; FOUCAULT, Michel (1996), "Che cos'è un autore?", en Scritti letterari, Feltrinelli, Milán; AUERBACH, Erich (1968), Mimesis: la représentation de la réalité dans la littérature occidentale, Gallimard, París; WATT, lan (2017), Le origini del romanzo borghese: studi su Defoe, Richardson e Fielding, Bompiani, Milán; y CAGLIOTTI, Daniela Luigia (2005), "In evidenza. Introduzione. Romanzo e storia", Contemporanea, vol.VIII:4. 
sintomática entre las consignas y las estrategias comunicativas en juego, lo que restituyó una cierta homogeneidad al discurso. Inmediatamente después del fracaso revolucionario, tanto los individuos más prominentes del nacionalismo moderado y democrático (Garibaldi, Sebregondi, Capranica, etc.) como el nuevo periódico La Civiltà Cattolica se consagraron a la producción del género literario más de moda, la novela histórica, un producto muy solicitado por un público -burgués- voraz y en expansión. En este contexto, la Curia romana comprendió perfectamente la importancia estratégica de este nuevo medio, y lo empleó para transferir contenidos políticos y morales entre líneas, casi al descuido, entreteniendo y dejando que los objetivos ideológicos se deslizaran por canales más ligeros, menos polvorientos y exigentes que las disquisiciones teológicas, y en consecuencia más eficaces y exitosos para la difusión pública. En este terreno, las dos plumas más célebres del periódico jesuítico fueron las de Antonio Bresciani y Giuseppe Franco, incansables soldados de Pío IX en la guerra sin cuartel contra la modernidad. Una gran parte de los temas que se han analizado en los apartados anteriores se hallan también en las páginas y las frecuentes conexiones intertextuales que estructuraron los textos reaccionarios y del Risorgimento.

George Mosse ha rastreado en el período napoleónico y revolucionario el surgimiento de un nuevo ideal europeo de virilidad heroica, cristalizado en las características masculinas del valor, la intrepidez y el autocontrol. Estos se consolidarían como elementos definitorios a lo largo del siglo XIX, en estrecha relación con la formación de los estados nacionales de base étnica, los cuales estaban intrínseca y necesariamente volcados en la búsqueda de las señas de identidad que caracterizasen la definición del relato, decisivo en el discurso nacionalista, de exclusión/inclusión. ${ }^{41}$ Por otra parte, Lucy Riall sostiene que a través de la acción bélica -sea en las filas del ejército regular o de las unidades de voluntarios- el sistema de valores viriles se define en términos físico-corporales, ya que "il guerriero moderno si pone al fianco del giovane greco", aunque se enriquece con narraciones artísticas y funcionales que definen un "mito dell'esperienza della guerra"

41 MOSSE, George (1997), L'immagine dell'vomo. Lo stereotipo maschile nell'epoca moderna, Einaudi, Turín, pp. 66 y ss. Véase también RIZZO, Domenico (2003), "Mariti e mogli adultere in età liberale", Genesis, vol. II, pp. 15-32; LANZINGHER, Margaret y RIZZO, Domenico (eds.) (2014), Il corpo della famiglia, II Mulino, Bolonia; BENADUSI, Lorenzo y CARAVALE, Giorgio (eds.) (2012), Sulle orme di George L. Mosse: interpretazioni e fortuna dell'opera di un grande storico, Carocci, Roma; y BENADUSI, Lorenzo (2015), Ufficiale e gentiluomo: virtù civili e valori militari in Italia (1896-1918), Feltrinelli, Milán. 
que "guarda al conflitto come a un evento carico di senso, positivo e anzi sacro". ${ }^{42}$ Sostiene Mosse que el estereotipo -producto de la hegemonía masculina-43 mantuvo su continuidad "dalla Francia rivoluzionaria fino alla seconda guerra mondiale". ${ }^{44}$ Por lo tanto, y en paralelo, como ha hecho notar Roberto Bizzocchi, ${ }^{45}$ durante el Risorgimento se asiste a una normalización de los equilibrios familiares y de la moral sexual y de género (fidelidad, independencia, roles, exposición pública), que se caracteriza por una progresiva erosión de la autonomía femenina y una rígida definición de roles, en el contexto más amplio de la afirmación de la sociedad burguesa: "polemica contro i valori cetuali di antico regime, adesione in chiave liberale e progressista al Romanticismo, importanza cruciale della maternità, serietà sentimentale e impegno di fedeltà fra coniugi con il rifiuto del cicisbeismo, severità dei costumi" ${ }^{46}$

Entrando ya en materia, lo que sorprende a un lector de hoy en el análisis de las novelas populares de fondo histórico o ideológico es la omnipresencia de la sexualidad, el recurso constante a las alusiones sexuales y la insistencia sobre la dimensión corporal de los personajes. En este aspecto no hay diferencias entre los textos reaccionarios y las obras patrióticas. En el universo del discurso de las novelas analizadas, lo físico-corporal es más que una figura retórica-una metonimia-: es una descripción o alusión que está ahí para otra cosa. En general, la belleza expresada literariamente es la medida de la catadura moral del personaje y, en consecuencia, el primer dispositivo de separación entre nosotros y los otros, entre personajes positivos y figuras antagonistas, lo que lo convierte en un instrumento, tan banal como eficaz, de búsqueda de empatía con el lector (y, claro, de persuasión ideológica). Sin embargo, la apelación a la belleza como termómetro ético y garantía de probidad -así como de afinidad ideológica- no debe entenderse en términos exageradamente esquemáticos, muy al contrario.

Un exponente revelador a este respecto son las descripciones de la femineidad, donde a menudo el énfasis en la belleza del personaje incorpora

42 RIALL, Lucy (2007), "Eroi maschili, virilità e forme della guerra", en BANTI y GINSBORG (eds.), Storia d'Italia. Annali 22, p. 257.

43 CONNELL, Raewyn W. (1996), Masculinities, Polity Press, Cambridge. Plantea un análisis cultural de la masculinidad nacionalista realizado a partir del modelo analítico gramsciano y de la noción de hegemonía.

44 MOSSE, George (1990), Le guerre mondiali. Dalla tragedia al mito dei caduti, Laterza, Roma-Bari, p. 7.

$45 \mathrm{BIZZOCCHI,} \mathrm{"Una} \mathrm{nuova} \mathrm{morale} \mathrm{per} \mathrm{la} \mathrm{donna} \mathrm{e} \mathrm{la} \mathrm{famiglia",} \mathrm{pp.} \mathrm{69-96.}$

46 BIZZOCCHI, "Una nuova morale per la donna e la famiglia", p. 90. 
un juicio de signo negativo, que se vuelve legible a través de un repertorio específico de señales, referidas de diversos modos a la sensualidad. Así, la belleza ya no es una metonimia, sino que se limita a ser una propiedad de lo femenino, y las señales interpretativas -la sensualidad insinuantedesempeñan una función de indicadores de moralidad. En este sentido, la ausencia o presencia de connotaciones explícitamente sexuales insertas en la descripción indican la posición que ocupa el personaje femenino en la estructura narrativa y en el sistema de valores de la novela. En el Prode di Roma de Francesco Sebregondi, la duquesa, figura negativa y tentadora, se distingue por su belleza femenina y por su-asimismo femenina- peligrosa e impía frivolidad:

Alta della persona, il moto del suo passo avea qualche cosa del maestoso, che nulla toglieva alle grazie irrequiete di due anche da statua greca, [...] la vedemmo appoggiata all'angolo di quel camino, con uno sguardo forse troppo curioso, indovinammo a bella prima che, nelle sue pose, la nobil donna sapea accoppiare la severità del sussiego all'enigmatico vezzo di una plastica piaggeria. [...] Ella rivolse a Ugo tale uno sguardo pieno di fascino e di passione, che parea volesse tradurre l'atto d'amnistia in un abbandono di tenerezza. Le sue labbra si apersero ad un sorriso di voluttà indescrivibile; il bulbo di quegli occhi divini nuotava nel glutine azzurro della donna che si oblia [...] appoggiando lievemente la sua bella testa sul dossiere del divano, parea dicesse: la schiava perdona al suo dominatore. ${ }^{47}$

El fragmento citado es emblemático porque condensa el arsenal narrativo y estratégico que se reserva a lo femenino en la novela histórica de actualidad, una panoplia discursiva que, vista la omnipresencia explícita o latente de la sexualidad y la centralidad de la mujer, configura esta tipología textual como un decálogo de deberes y prohibiciones de género.

Es asimismo representativo de la función novelesca de la feminidad el capítulo "Le due cognate", que Bresciani incluyó en su best seller para proporcionar, desde la óptica de la mujer, una lectura política autoevidente, que se logra gracias a la yuxtaposición de dos modelos femeninos antitéticos. Como ha señalado Paolo Orvieto, las dos cuñadas romanas Laura y Metilde, "una tutta bianca e una tutta nera", brindan el "pretesto per una

47 SEBREGONDI, Francesco (1864), Un prode di Roma (1849-1862), G, Brigola, Milán, pp. 214 y 247. 
infervorata discussione" política y antifeminista: en las mujeres, sostiene el jesuita, "le idee sbagliate si radicano più facilmente e sono più difficilmente estirpabili, perché le donne, meno intelligenti, meno razionali e assai più cocciute dell'vomo, sono più facili da convincere e più difficili a ravveder-

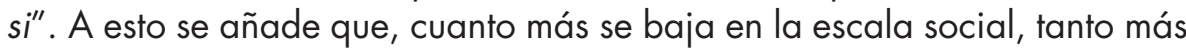
las mujeres son de "corti intelletti", por ello de más fácil conversión a las ideas liberales $y$, en fin, argumenta Bresciani con una vena misógina nunca desmentida, equiparables a "galline che covano vova di serpenti". ${ }^{48}$

Los personajes femeninos brindan, por tanto, la oportunidad de una definición del campo de supremacía política y las connotaciones de moralidad de una opción ideológica respecto a la otra: una moralidad reafirmada por la señalización de tipo sexual. Así, la mujer maléfica -sea la reaccionaria duquesa del Prode di Roma o la infernal mazziniana Babette- se vincula necesariamente a actitudes sensuales y a prácticas impropias -como la lectura de obras prohibidas: "ciò che per Eva fu il pomo vietato, per Eleonora è stata invece la cronaca dell'OEil de boeuf" $-{ }^{49}$ o la exposición pública del propio cuerpo en el caso de la bailarina Polissena. Como contraste, en los textos jesuíticos las figuras femeninas positivas son la base para la recomposición del equilibrio novelesco, que se consigue con el arrepentimiento, y la consiguiente confesión y/o conversión. Por otro lado, el análisis intratextual de las novelas históricas revela una meticulosa enumeración de los elementos de la conducta femenina aceptable. Las lecturas francesas son catalogadas como "pessimi libri", 50 porque representan para las muje-

48 ORVIETO, Paolo (201 1), Buoni e cattivi del Risorgimento: i romanzi di Garibaldi e Bresciani a confronto, Salerno Editrice, Roma, p. 121.

49 SEBREGONDI, Un prode di Roma, p. 217. Otro pasaje del texto confirma la insistencia en la dimensión sexual de la mujer y el peligro de su lascivia apasionada. El uso de un registro hiperbólico y alusivo transforma un pensamiento romántico en la transposición literaria del orgasmo: "L'Olimpo schiude le porte; Ebe versa nelle coppe dei nimbiferi immortali il nettare celeste; ai concenti della lira d'Orfeo risponde dal bosco il verso fescennino sacro al figlio di Urano e di Vesta. Le orgiasti sacerdotesse scuotono il tirso a iniziano il mistero di Bacco; la bianca Giunone scioglie la chioma profumata; Minerva lascia cadere sul pavimento dell'egiaco padre il rabescato peplo; gli dei tripudiano, e il bellissimo torso dell'Apollo di Belvedere stupendamente inciso da bulino maestro, e su cui la stanca sognatrice lasciò cadere la vellutata carta velina, a poco a poco scompare dietro una nebbia biancastra.... si sfuma... l'apoteosi della materia si compie sotto le volte dell'empireo pagano. I contorni dell'antica scollatura ammaliarono l'incauta: la materia soffoca, si contorce, divampa; il pensiero crea, soffre e si corrompe" (p. 218).

50 PICCHIORRI, Emiliano (2008), La lingua dei romanzi di Antonio Bresciani, Aracne, Roma, p. 25. 
res lo que "fu per Eva il pomo vietato" e inducen a las lectoras inexpertas, "siccome è uso al gentil sesso", 51 a la ligereza frívola, en tanto que el teatro, la música y sobre todo el baile son nada menos que lo propio de una "diavolessa" o una "baccante". ${ }^{52}$ La exclusión del elemento femenino de la vida social activa, prerrogativa masculina, queda plenamente de manifiesto en un fragmento del Prode di Roma. Aquí la duquesa, acostumbrada a las lascivias de las lecturas frívolas, mancilla doblemente el sagrado pacto matrimonial: no solo trastoca la natural subordinación respecto al marido, sino que llega a atentar contra su honor al ofrecerse carnalmente al revolucionario Ugo:

La duchessina [...] si scioglieva le ordelline dell'angusto corsetto per svestirsi [...]. Era elaterio dell'animo, era fuoco delle vene quello che placava la dea magnanima? Lo sapremo: il fatto sta che si diede ad ondeggiar tra il bene e il male, come una nuova Eva pronta ad ascoltare per una seconda volta il serpente; e ad ogni gonna che leggiadramente le cadea giù dalle duttili anche per aggrovigliarsi attorno ai piedi d'avorio, dessa diveniva sempre più mite e men fiera. Quando sentì il diffuso volume delle sue chiome sciogliersi sulle spalle nevose, provò un brivido per tutte le ossa, mandò un sospiro e strinse finissime le labbra. ${ }^{53}$

El protagonista Ugo, no hará falta decir que dotado de la contención viril que caracteriza a los personajes positivos de la literatura de consumo, resiste a la tentación, "perdonandola" ${ }^{54}$ La convicción de lo peligroso de la libertad extradoméstica femenina presupone la de su minoría de edad intrínseca y confirma el riesgo que representa la subversión de los roles. Los modelos positivos que se proponen son, en realidad, argumentos para propugnar y estimular el "pudore di donna", ${ }^{55}$ la morigeración,, la hu-

51 GARIBALDI, Giuseppe (1870), Clelia, ovvero il governo del monaco (Roma nel XIX secolo), Fratelli Rechiedei, Milán, p. 169.

52 SEBREGONDI, Un prode di Roma, p. 65.

53 SEBREGONDI, Un prode di Roma, p. 113.

54 SEBREGONDI, Un prode di Roma, p. 114.

55 GARIBALDI, Clelia, p. 176.

56 PICCHIORRI, La lingua dei romanzi di Antonio Bresciani, p. 388. 
mildad como esencia de la femineidad y, por ende, la sumisión esencial al marido. Todo ello queda modélicamente sintetizado en la figura de la púdica Irene de Clelia -una novela escrita nada menos que por Giuseppe Garibaldi-, cuando al hablar de su consorte asegura "sentivo di esser sua, ed egli avrebbe potuto disporre di me come d'una schiava" ${ }^{57}$ En lo que a la condición femenina respecta, los textos aquí considerados consiguen un efecto paradójico: a la centralidad (aunque casi nunca protagonismo) de las mujeres, siempre muy clara en la arquitectura novelesca, le corresponde sin embargo su marginación social y de género.

Hay que hacer también una breve mención al honor y a la pureza de sangre cuando se trata del papel de las mujeres en la trama romántica. Como ha subrayado Banti, que en esto se alinea con George Mosse, la femineidad representa la estratagema para trazar rígidas líneas de división y selección étnicas, la contraposición biológica y sexual entre nosotros y los otros, con una función nacional y xenófoba (el croata, los franceses de las Vísperas Sicilianas, etc.) o, en los casos aquí examinados, con finalidades políticas (demostrar la abyección del jesuita o la inmoralidad del sectario). La violación o el intento de violación, contempladas como prácticas asiduas, se reservan para la demonización del adversario ideológico, con su representación caricaturesca e inhumana: baste pensar en el mazziniano Lionello, que comete infanticidio tras un rechazo carnal. ${ }^{58}$ Se hallará la misma respuesta en las páginas de Clelia donde, además de delinearse los rasgos satánicos y amorales del violador adversario, se toma del canon el imperativo categórico de la pureza, hasta llegar al suicidio por deshonor:

Invano egli la supplicò, adoperando tutte le lusinghe di cui era capace - sempre più fieramente le rispondeva la nostra eroina - laonde - furioso il prete che vedeva scorrere il tempo senza approdare a nulla [...]. Clelia trasse risolutamente il pugnaletto - e mentre furibonda e con voce commossa esclamava: "Piuttosto m'immergerò questo ferro nel cuore. ${ }^{59}$

57 GARIBALDI, Clelia, p. 177.

58 Por otra parte, Lionello o delle società segrete ha sido interpretado como una respuesta a la Vita di Garibaldi de Giovanni Battista Cuneo. PICCHIORRI, La lingua dei romanzi di Antonio Bresciani, p. 47.

59 GARIBALDI, Clelia, cit. p. 91. 
Como han sostenido Banti y Bizzochi, durante el siglo XIX se establece una nueva moral familiar, que se contrapone a las licenciosas costumbres aristocráticas del Ancien Régime, bien documentadas en los estudios de Michel Vovelle o Robert Darnton. ${ }^{60}$ La nueva perspectiva de lo doméstico responde a la necesidad de dar a los hijos una educación hecha de cuidados amorosos y no de liviandades, que sea capaz de forjar -no necesariamente solo en un sentido nacional- una nueva generación de hombres ( $y$, funcionalmente, de mujeres). No se hacen concesiones a los placeres carnales extraconyugales, a los que se considera una práctica antisocial: así, la mujer tiene que ser "pudica", ${ }^{61}$ "umile", 62 "pura", "casta, ideale", tiene que rechazar la lascivia, la indolencia y la frivolidad que en principio le son congénitas, ${ }^{64}$ para consagrarse a su mayor deber. Es de lo más explícito este fragmento de la obra de Sebregondi, que combina lo naïf con el orgullo patriarcal:

Povera creatura che è la donna! Ella non vede che famiglia e pace, non riposa il suo pensiero che negli affetti materni, e noi se l'incontriamo in un ballo non le parliamo altro che della sua eleganza e delle sue grazie, e non mai de' suoi figli; e sì che in essi sta tutta la sua esistenza! 65

La moralización de la sociedad se liga doblemente al discurso nacional, que tiene su más firme puntal en la regeneración biológica de la especie y en la figura normalizada de la mujer-madre; el atentado contra la sexualidad femenina representa una amenaza para toda la comunidad de

60 DARNTON, Robert (1997), Libri proibiti: pornografia, satira e utopia all'origine della rivoluzione francese, Mondadori, Milán; VOVELLE, Michel (1989), "La "coda" di Danton o massacro e sessualità: violenza e fantasmi erotici nelle letture della Rivoluzione francese", en Immagini e immaginario nella storia. Fantasmi e certezze nelle mentalità dal medioevo al Novecento, Editori Riuniti, Roma, pp. 239-247; y BANTI, Alberto Mario (2016), Eros e virtù. Aristocratiche e borghesi da Watteau a Manet, Laterza, Roma-Bari (edición digital), 2016.

61 GARIBALDI, Clelia, p. 176.

62 SEBREGONDI, Un prode di Roma, p. 56.

63 GARIBALDI, Giuseppe (1870), Cantoni il volontario. Romanzo storico, Kaos edizioni, Milán, (ed.2006), p. 240.

64 CAPRANICA, Luigi (1857), Giovanni delle bande nere, Dalla Tipografia del Commercio, Venecia, vol. II, p. 116.

65 SEBREGONDI, Un prode di Roma, pp. 396-397. 
sangre y se convierte en un motor retórico del nacionalismo y de toda su eficacia comunicativa. La dimensión familiar de la mujer se combina con la vocación y las necesidades de la nación, que recaen en la figura de la esposa y madre, de la que se espera, además de otros cometidos biológicos esenciales, que inculcará el amor a la patria. Así, "la creatura santa delle pareti domestiche" 60 que con "il primo bacio della madre incide sulla fronte dell'vomo l'onore", 67 es compelida a celebrar " $i$ valorosi, $i$ vincitori dell'oppressore" -"beateli!"-, ya que estas"[queridas mujeres] son degni di voi, del vostro sorriso, del vostro amplesso e dell'amor vostro! Essi sparsero il loro sangue, cimentarono la loro vita per non lasciarvi ludibrio a sgherri". ${ }^{68}$

Ilaria Porciani ha escrito que "un momento centrale -forse il più decisivo- per la costruzione della coppia famiglia-nazione è il 1848", ${ }^{69}$ no solo porque las mujeres estuvieron en las barricadas y tomaron parte en las grandes liturgias públicas, sino porque en esta divisoria histórica se consolidó y certificó una refundación de las costumbres, una redefinición de los roles acuñados sobre las virtudes privadas que, al hilo de las reflexiones de Rousseau y Montesquieu, pasaron a considerarse "una conquista indispensabile a restituire dignità e credibilità alla comunità di appartenenza" ${ }^{70}$

Bien mirado, el análisis intertextual de novelas ligeras con antecedentes históricos ofrece una definición rígida del papel de la mujer en una perspectiva social y étnico-nacional más amplia. Las figuras femeninas positivas se mueven en el escenario único de la intimidad familiar, a cubierto de "occhi indiscreti", ${ }^{71}$ se dedican a engendrar hijos, a educarlos y a confortar, en funciones estrictamente auxiliares, a maridos, padres y hermanos. Lo que más sorprende, sin embargo, es la casi total coincidencia a este respecto entre los registros utilizados en los textos reaccionarios y en los patrióticos. La mujer -un lexema que en las figuras positivas conoce una transfiguración sinonímica que lo transforma en madre- es el "cuore d'angiolo per le delizie della sua famiglia", ${ }^{72}$ vive su "apostolato di amore celestiale"

66 SEBREGONDI, Un prode di Roma, p. 488.

67 SEBREGONDI, Un prode di Roma, p. 464.

68 GARIBALDI, Cantoni, p. 213.

69 PORCIANI, "Disciplinamento nazionale e modelli domestici nel lungo Ottocento", p. 115.

70 SOLDANI, Simonetta (2007), "II Risorgimento delle donne", en BANTI y GINSBORG (eds.), Storia d'Italia. Annali 22, p. 185; y McCLINTOCK, Anne (1993), "Family feuds: gender, nationalism and the family", Feminist Review, vol. 44, pp. 61-103.

71 SEBREGONDI, Un prode di Roma, p. 83

72 GARIBALDI, Clelia, p. 7. 
como "pura consolatrice dell'vomo" y educadora en la "santa famiglia".$^{74}$ Para corroborar esa centralidad asignada a la dimensión doméstica valga el caso de Beniamina, de Giovanni Giuseppe Franco: aquí las peripecias, las vicisitudes y los sufrimientos que envuelven a la piadosa protagonista se imputan, no solo a la indudable seducción liberal, sino también y sobre todo a la labor educativa y de control que ha descuidado la madre de Luisella, la antiheroína. Por eso, en el epílogo pedagógico que sigue a la muerte, una vez convertida, de la antes sectaria Luisella, Franco hace pronunciar a don Catone unas palabras que suenan a la vez como una advertencia y como una conminación

Fatta celebrare per l'anima di lei una Messa di requiem, nella quale tutte e quattro si comunicarono, furono poscia in sagrestia per depositarvi le candele, che doveano ardere all'altare della Vergine. Fra Catone, che era venuto apposta per confortarle, ed avea offerto il Sacrifizio, cercava di loro suggerire alcune ragioni di rassegnazione: la Marianna gli rispose: - Padre, voi speravate che la Madonna avrebbe ricondotto quella poveretta pentita a suoi piedi. Ora, bontà di Dio, pentita e ravveduta è stata; ma á piedi della Madonna non potendo essa, ha desiderato prima di morire, che venissimo noi in sua vece; ed ecco che fare quel pellegrinaggio fallito allora...- Volea dire di più; ma fu interrotta da singhiozzi, ai quali si accoppiarono le lagrime ancora delle fanciulle. Il buon religioso si argomentò di racconsolarle del suo meglio; e fini col dire: - Basta! Se non ci fossero i grandi peccati, noi neppure conosceremmo le grandi misericordie; e ad ogni modo i traviamenti di quella poveretta potranno servire alla istruzione di molte madri. - La quale ultima parola fra Catone proferì con particolare espressione, affissando severamente la Marianna, certo per ammonirla, che delle colpe e delle sventure della figlivola una qualche ammenda restava a fare anche a lei. ${ }^{75}$

73 FRANCO, Giovanni Giuseppe (1863), Le cospiratrici, Immacolata Concezione, Módena, p. 170.

74 GARIBALDI, Clelia, p. 3.

75 FRANCO, Giovanni Giuseppe (1866), "Beniamina", en Sei racconti, Pietro di G. Marietti, Turín, (3a ed.), vol. I, p. 337. 


\section{CONCLUSIONes}

Las tipologías documentales analizadas devuelven el uso de lo femenino en la historia revolucionaria con una frecuencia casi obsesiva, una insistencia que se despliega en al menos tres niveles. Primero, el de los elementos estilísticos figurativos, que ven la patria representada alegóricamente en el cuerpo de una mujer con el pecho descubierto y la cruz en la mano (Figura 7), un emblema artístico del nacionalismo italiano del siglo XIX que se refiere a la función generadora y educativa de la patria. En segundo lugar, lo femenino se usa como una estratagema narrativa (vuélvase a los textos de Bresciani analizados en este ensayo) para definir la bondad o no de cada opción ideológica, enriqueciendo la moralidad con el elemento político a través del comportamiento, bueno o malo, de los protagonistas. Así, las lecturas peligrosas e indecorosas en francés sancionaron el engaño de Mazzini "della infernale Babette", mientras que el digno y modesto rechazo del adulterio de la Clelia garibaldina confiere virtud y honor, no solo al protagonista, sino también a la causa nacional.

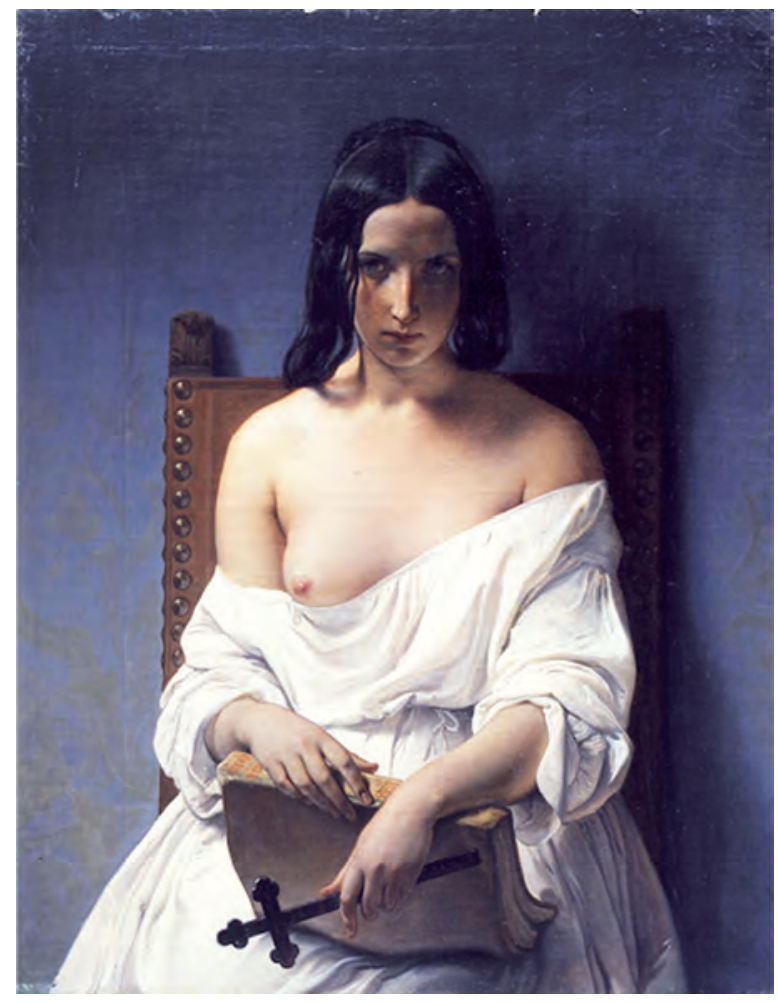

Fig. 7. 
La última consideración permite pasar al tercer y más importante punto de partida hermenéutico, que es la fisionomía social que estos medios parecen postular y/o proponer y en los cuales la mujer aparece como el eje indiscutible. La figura femenina queda encerrada, pues, en los muros domésticos, donde encuentra su lugar de elección y su realización, como generadora y educadora de los niños -"I'angello della famiglia" según Mazzini-, a los que la retórica nacionalista quiere saludables, fuertes y viriles, capaces de crear esa comunidad de armas requerida para construir y defender la patria. Esta, además, se configura como un territorio de hegemonía exclusivamente masculina. Salvo algunas excepciones esporádicas, la presencia de las mujeren en público y su participación activa en la vida política y social se consideraron inconvenientes, cuando no peligrosas y antisociales, tanto por la insuficiencia femenina congénita para administrar la res publica (Figura 2) como por el riesgo de presentarse ante la mirada del otro (Figura 3), arriesgándose a violar el vínculo sagrado del matrimonio, el fundamento de la familia nuclear burguesa y la comunidad de sangre invocada por el nacionalismo. Así adquieren significado las apelaciones obsesivas a la pureza de la sangre y la defensa del honor, tanto en la función xenófoba (Figura 4) como en lo tocante a la respetabilidad familiar. La cuidadosa atención y la convergencia que se registran en las diversas producciones y que atraviesan todos los medios aquí explorados certifican el papel central -aunque, por supuesto, en una función pasiva y subordinada- reconocido a las mujeres, comow ángeles guardianes del universo doméstico y familiar, que tanto el nacionalismo como el clericalismo valoraron como el cimiento de la nación y su reserva espiritual. 


\title{
LA PARTICIPACIÓN DE LA MUJER EN LAS DISTINTAS FORMAS DE RESISTENCIA DURANTE LA OCUPACIÓN DE GRECIA POR LAS FUERZAS DEL EJE (1940-1944)
}

\author{
WOMEN'S PARTICIPATION IN DIFFERENT FORMS \\ OF RESISTANCE DURING THE OCCUPATION OF \\ GREECE BY THE AXIS POWERS (1940-1944)
}

Maila García Amorós

Universidad de Granada

\section{RESUMEN}

Desde los primeros momentos de la Ocupación las mujeres se organizaron para emprender acciones destinadas a paliar la situación que trajo a la nación la invasión de las fuerzas del Eje o para combatir al invasor directamente. En un primer momento su participación en actos de Resistencia, podrían considerarse una extensión de las labores que tradicionalmente había desempeñado, haciéndose cargo de la atención de los soldados y de la población civil que había permanecido en los pueblos y ciudades. Paulatinamente, las mujeres fueron asumiendo roles hasta ese momento restringidos a los hombres. Fueron muchas las que a través de diversas agrupaciones participaron activamente en la Resistencia. Muchas de ellas emprendieron iniciativas particulares mediante las cuales salvaron numerosas vidas o infringieron daño al enemigo. No faltaron, por otro lado, las que incorporándose al ejército lucharon como partisanas y tomaron parte en la batalla al lado de los hombres. Objetivo de este trabajo es destacar la labor de todos estos grupos de mujeres que de un modo u otro presentaron resistencia contra el invasor.

Palabras clave: Ocupación, resistencia, mujer, partisana, emancipación.

\begin{abstract}
From the very beginning of the Occupation, women organized themselves to carry out acts in order to alleviate the situation brought upon the nation by the Axis powers, or to directly fight against the invader. Initially, their participation in these actions could be considered an extension of the tasks they had traditionally carried out but they were no less important because of that. In this way,
\end{abstract}


they began to take care of the soldiers and civilians who stayed in the villages and towns. The women gradually took on roles which until then had been restricted to men. Many women enlisted and contributed to the resistance struggle through the different groups they established. There was also an important number of women who were posted in the mountains and took part in the fighting alongside the men. Nor should we forget those who undertook specific initiatives, by means of which they saved many lives or inflicted injury on the enemy. The aim of this essay is to highlight the work of all these groups of women who in one way or another showed resistance against the invader.

Keywords: Ocupation, resistence, women, partisan, emancipation.

\section{RESUM \\ LA PARTICIPACIÓ DE LA DONA EN LES DIFERENTS FORMES DE RESISTÈNCIA DURANT L'OCUPACIÓ DE GRÈCIA PER LES FORCES DE L'EIX (1940-1944)}

Des dels primers moments de l'Ocupació, les dones s'organitzaren per a emprendre accions destinades a pal.liar la situació que va portar a la nació a la invasió de les forces de l'Eix o per a combatre a l'invasor directament. En un primer moment la seua participació en actes de Resistència, podria considerar-se una extensió de les tasques que tradicionalment havien desenvolupat, fent-se càrrec de l'atenció dels soldats i de la població civil que havia restat en els pobles i ciutats. Gradualment, les dones assumiren rols fins eixe moment restringits als homes. Van ser moltes les que a través de les diverses agrupacions participaren activament a la Resistència. Moltes d'elles van emprendre iniciatives particulars mitjançant les quals salvaren nombroses vides o van infringir mal a l'enemic. No faltaren, per altra banda, les que incorporant-se a l'exèrcit lluitaren com a partisanes i van prendre part a la batalla al costat dels homes. L'objectiu d'aquest treball és destacar la feina de tots aquests grups de dones que d'una manera o altra presentaren resistència contra l'invasor.

Paraules clau: Ocupació, resistència, dona, partisana, emancipació. 
"Cuando hablamos de Resistencia, nuestra mente no ha de ir sólo a la lucha armada, al frente y a las montañas. Cuando hablamos de Resistencia nacional no nos referimos sólo a aquellos que participaron activamente en el combate o que pertenecieron a organizaciones. Entre los miembros de la Resistencia no hemos de contar sólo a aquellos que se jugaron la vida todos los días o a los osados jóvenes que iban a la vanguardia. Cuando hablamos de Resistencia griega, no nos referimos sólo a los prisioneros, a los rehenes, a los ejecutados, sino que incluimos a todos aquellos que se opusieron de alguna manera al invasor. Incluimos a aquellos que con su desobediencia a las órdenes del invasor, con su negativa y su oposición a aceptar cualquiera de sus disposiciones, no se rendían sino que luchaban. Resistencia presentó el combatiente, pero también aquel que no creyó en lo que dictaba el opresor. Presentó resistencia aquel que daba un trozo de pan al hambriento y un vaso de agua al sediento para calmar su sed".

1 GLEZOS, Manolis (2009), EӨvıkń Avtíotaбıs, tomo I, Stochastís, Atenas, p. 61. 
Como señala con estas palabras el autor de uno de los primeros actos de resistencia en la Grecia ocupada, Manolis Glezos, ${ }^{2}$ la Resistencia no consistió sólo en la lucha armada o en las acciones de sabotaje llevadas a cabo contra el invasor, sino que también hemos de considerar actos de resistencia todos aquellos gestos y acciones gracias a los cuales esta lucha pudo sostenerse. Nos referimos con esto a las muchas iniciativas de las personas que permanecieron en las ciudades y los pueblos para hacer frente a la situación, paliar los efectos de la invasión y combatir, cada uno en la medida de sus posibilidades, al invasor. La mayoría de estas iniciativas fueron promovidas por mujeres, que fueron quienes se quedaron al cargo, no sólo de sus propias familias, sino también de la población civil en general. A lo largo de estas páginas, iremos viendo en qué consistió esta labor y cómo paulatinamente las mujeres fueron involucrándose en actividades hasta entonces llevadas a cabo por hombres, como la colaboración en la Resistencia y la participación como partisanas en las guerrillas.

\section{LA INVASIÓN DE GRECIA Y SU ENTRADA EN LA SEGUNDA GUERRA MUNDIAL}

Tras el estallido de la guerra en Europa, el dictador griego loannis Metaxás, ${ }^{3}$ en el poder desde 1936, trató de llevar a cabo una política neutral tanto con Inglaterra como con Alemania, con la voluntad de mantener a Grecia apartada del conflicto. Sin embargo, las provocaciones por parte de Italia para que Grecia entrara en la guerra eran continuas. A principios de 1940 Italia torpedeó el Crucero griego Elli, mientras que el 28 de octubre de 1940 el gobierno de Mussolini lanzaba un ultimátum al gobierno griego, según el cual éste debía ceder a los italianos algunas bases militares y territorios de los que harían uso hasta el final de la guerra. Este ultimátum fue rotundamente rechazado por Metaxás, quien no pudo evitar

2 La noche del 30 de mayo de 1941, dos jóvenes estudiantes escalaron la roca en la que se erige la Acrópolis de Atenas, arriaron la bandera alemana con la esvástica que los alemanes habían colocado tras su entrada en Atenas e izaron la bandera griega. Este fue considerado el primer acto de resistencia contra el invasor. Uno de esos jóvenes era Manolis Glezos, quien continuó participando en actos de resistencia durante toda la Ocupación y fue detenido y torturado en varias ocasiones, logrando siempre salvar su vida. Después de la guerra civil griega (1946-1949) se dedicó a la política militando en la izquierda y siendo diputado en varias ocasiones, la última en 2014. A día de hoy, a sus 96 años, Siguió participando en mitines políiticos y publicando libros y artículos de opinión en la prensa griega hasta su muerte a los 97 años, el 30 de marzo de 2020, durante el confinamiento del COVID-19.

3 Esta negativa rotunda de Metaxás, conocida como "El Gran No", sigue celebrándose hoy día en Grecia como fiesta nacional cada 28 de octubre. 
que pocas horas más tarde, las tropas italianas pasaran por la fuerza a Grecia a través de la frontera con Albania y el país entrara así en la guerra del lado de los aliados. ${ }^{4}$

Inmediatamente después de la declaración de guerra, el ejército griego se concentró en la frontera de Albania, donde logró frenar a las tropas italianas y las hizo retroceder. Los éxitos militares del ejército griego fueron tales, que llegaron a conquistarse algunas ciudades fronterizas de Albania en las que había una importante población griega. Sin embargo, la llegada del invierno puso fin a las campañas militares. Entretanto, Inglaterra había ofrecido colaboración a Grecia, colaboración que fue rechazada por Metaxás en la idea de que, de esta manera, podría evitar el conflicto con Alemania. ${ }^{5}$ No obstante, al morir Metaxás en enero de 1941, su sucesor, Aléxandros Korizis, no tuvo tales miramientos. La ayuda prometida por los ingleses llegó, pero muy tarde, cuando ya no había forma de frenar a las tropas alemanas que finalmente entraron a Grecia por la frontera con Yugoslavia y Bulgaria el 6 de abril de 1941.6

En medio del caos que sobrevino, Aléxandros Korizis se suicidó. La mayor parte de la fuerza expedicionaria inglesa fue evacuada junto con el Gobierno y la Casa Real, que marcharon a Creta con el fin de proteger la isla de la invasión y organizar desde allí la Resistencia. Sin embargo, la isla cayó poco tiempo después, en mayo del 41 , tras una sangrienta batalla de la que las fuerzas alemanas salieron debilitadas. ${ }^{7}$ La Casa Real y el Gobierno marcharon entonces a Oriente Próximo, estableciéndose en Grecia un gobierno colaboracionista encabezado por el general Yorgos Tsolázoglu. ${ }^{8}$ A principios de junio de 1941, la totalidad de Grecia se encontraba ya sometida por Alemania, que ocupó Atenas, Macedonia, la frontera con Turquía y parte de la isla de Creta, por Italia, que ocupó el Peloponeso y

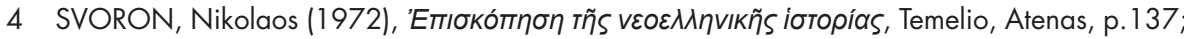

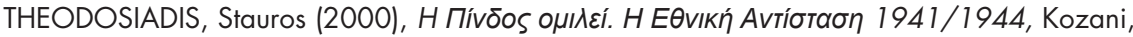

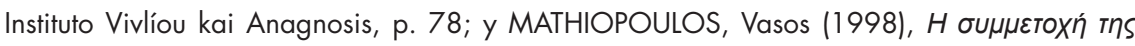

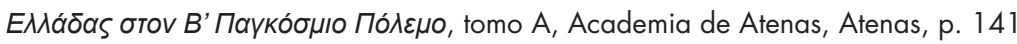

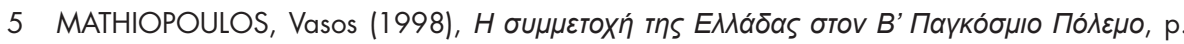
256.

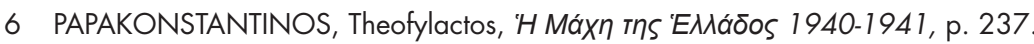

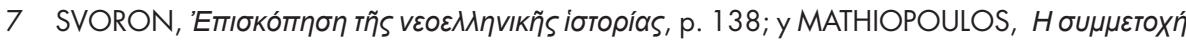

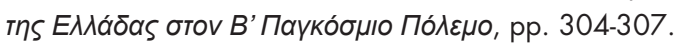

8 El 23 de abril, tres días antes de la entrada de las tropas en Atenas, Yorgos Tsolázoglu había pactado con los alemanes un armisticio sin la autorización gubernamental. Tras la marcha de la familia real y el contingente británico, formó un gobierno colaboracionista. CLOGG, Richard (1998), Historia de Grecia, Cambridge University Press, Cambridge, p. 121. 
Grecia Central y por Bulgaria, a quien se le permitió ocupar la Tracia Occidental y parte de Macedonia, donde la población griega fue víctima de persecuciones y exterminios. ${ }^{9}$

\section{LABOR ASISTENCIAL DE LAS MUJeres tRAS LA ENTRADA DE GRECIA EN LA GUERRA}

Poco después del primer acto simbólico de resistencia perpetrado por Manolis Glezos y Apóstolos Santas con el izado de la bandera griega en la Acrópolis, comenzó a gestarse la idea de una Resistencia griega. En julio de 1941 habían tenido lugar algunas reuniones clandestinas con el fin de analizar la situación y empezar a organizarse. Sin embargo, los desacuerdos surgidos entre los líderes de las distintas orientaciones políticas dieron al traste con la idea de una Resistencia sólida y unida. ${ }^{10}$ Aprovechando esta situación de desacuerdo, el Partido Comunista (KKE) creó la agrupación EAM, ${ }^{11}$ de la que a finales de 1941 surgiría el ELAS, ${ }^{12}$ su brazo militar, que comenzó a desarrollar una intensa actividad. Otros oficiales del ejército griego fueron fundando grupos de resistencia no comunistas como el EDES, ${ }^{13}$ bajo el mando del general Napoleón Zervás, quien se apostó

9 La cifra de víctimas griegas a manos de los búlgaros ascendía a unas 15.000 , tras las matanzas colectivas perpetradas en Drama, Kavala, Doxato y otros pueblos. VAKALÓPULOS, Apóstolos (1995), Historia de Grecia Moderna (1204-1985), Universidad de Chile, Santiago, p. 324; y CONDOGEORGIS, Georgios (1992), Histoire de la Grèce, Hatier, París, p. 405.

10 VAKALOPULOS, Historia de Grecia moderna, p. 325; y GASPARINATOS, Spyros (1998), 'H

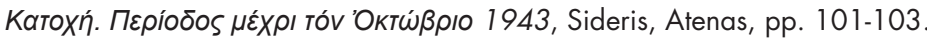

11 El EAM (Frente Nacional de Liberación) tenía dos objetivos fundamentales, en primer lugar, organizar la Resistencia y, en segundo lugar, consolidar una posición política preponderante que le permitiera, una vez terminada la guerra, asumir el poder político. CLOGG, Historia de Grecia, pp. 122 y 125; VAKALÓPULOS, Historia de Grecia moderna, p. 326; SVORON, iñs

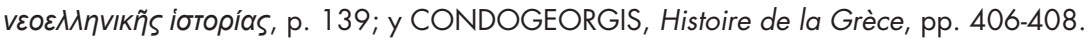

12 El ELAS (Ejército Popular de Liberación Nacional) aprovechó el vacío político originado en tiempos de Metaxás y su experiencia en la clandestinidad para organizarse como la mayor fuerza militar de la Ocupación. Esta ambición militar, pero también política, llevó al ELAS a numerosas confrontaciones y ataques contra otros grupos de la Resistencia no comunistas. CLO-

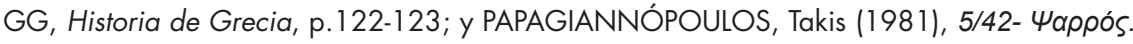

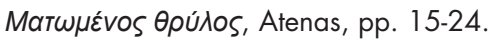

13 El EDES (Ejército Nacional Democrático Griego) fue la segunda agrupación de la Resistencia más fuerte después del EAM. Era de inspiración venizelista y socialista y se posicionó en contra de la monarquía, aunque posteriormente su líder Napoleón Zervás se declararía a favor del regreso del rey Jorge II. Entre sus logros más importantes destaca la destrucción del viaducto de Gorgopótamos el 25 de noviembre de 1942, que puso freno al paso de los suministros del Mariscal Rommel por Grecia. CLOGG, Historia de Grecia, pp. 219-220; y GASPARINATOS, 'H Kaтохи́, pp. 307-310. 
en las montañas a mediados 1942 y la EKKA, ${ }^{14}$ liderada por el coronel Dimitrios Psarós.

Con la marcha de los hombres al frente enrolados en las distintas agrupaciones de la Resistencia, las mujeres no tardaron en organizarse para tratar de cubrir las numerosas carencias de organización y medios materiales. Ya hacia 1939, en previsión de la guerra que se avecinaba, se habían puesto en marcha escuelas de enfermería, donde muchas jóvenes acudían a formarse a fin de prestar sus servicios en la guerra. Entre los organismos que ofrecían esta formación cabe destacar el Instituto de la Mujer Griega, ${ }^{15}$ que se comprometió desde el principio con la causa del apoyo al ejército. De esta manera, en octubre de 1940, 2.836 mujeres con formación en enfermería siguieron al ejército griego al frente de Albania para asistir a los soldados heridos o enfermos. Estas enfermeras, movilizadas por la Cruz Roja Griega, dotaron los 58 hospitales militares, las unidades avanzadas de salud pública, los hospitales móviles y los centros de primeros auxilios. ${ }^{16}$ El apoyo material a los soldados y guerrilleros constituyó desde el principio una de las preocupaciones más inmediatas tras el estallido de la Guerra. Iniciativa del Instituto de la Mujer Griega fue también la institución Franela para el Soldado, cuyo fin era proveer de ropas y mantas al ejército griego apostado en las montañas, donde el frío del invierno estaba haciendo estragos. Esta iniciativa se puso en marcha por un grupo de mujeres presidido por Elmina Votsi ${ }^{17}$ y funcionaba bajo los auspicios de la entonces princesa Federica. Franela para el soldado constituyó el principal esfuerzo

14 EKKA (Liberación Nacional y Social) fue una agrupación de inspiración socialdemócrata fundada por el coronel venizelista Dimitrios Psarrós. Llevó a cabo grandes avances militares, logrando liberar la zona de Ánfisa en noviembre del 43. Sin embargo, repetidos enfrentamientos con el ELAS llevaron a su disolución y al asesinato de su líder y fundador. PAPAGIANNÓ-

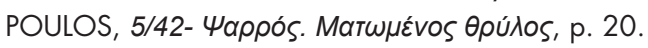

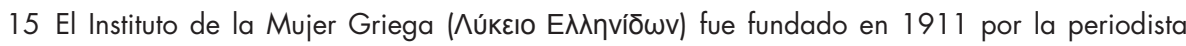
Calirroe Parén, una de las primeras feministas griegas, con el objetivo de combatir la xenofilia y preservar los usos y costumbres de Grecia. Ya en el periodo de entreguerras era un vestigio del antiguo feminismo y considerado bastante conservador. AVDELA, Efi y PSARRÁ, Angélica

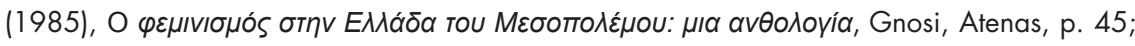

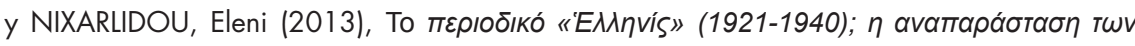

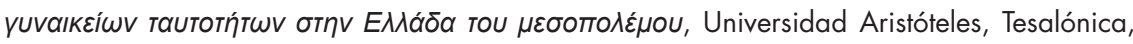
Tesis doctoral, p. 31.

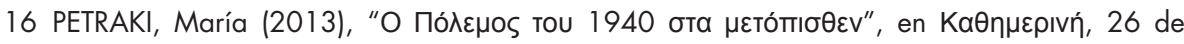
octubre de 2013 [https://www.kathimerini.gr/502233/article/epikairothta/ellada/o-polemos-toy-1940-sta-metopis8en] (última consulta 8 de julio de 2019).

17 La institución fue fundada ya en 1938 por Elimna Votsi, Alexandra M. Melá y Amalia Likou- 
y también el más efectivo para suplir las enormes carencias indumentarias del ejército griego ${ }^{18}$ e involucró a la inmensa mayoría de la población griega femenina de todos los rincones del país. ${ }^{19}$ Desde señoras de las grandes ciudades hasta aldeanas de las zonas agrícolas más aisladas, todas participaron aportando lo que cada una podía: materias primas, como lana de sus propias ovejas, sus telares para la elaboración de los tejidos o sus manos para la confección de las prendas. Se ha calculado que la producción de ropas y mantas ascendía a las tres mil piezas diarias. ${ }^{20}$

En lo que se refiere al apoyo material, no podemos dejar de hacer alusión a las mujeres de Pindos, cordillera montañosa al sureste de la frontera albanesa, que cargaron con el armamento y las provisiones para los soldados apostados allí y se lo hicieron llegar por caminos intransitables por donde no era posible el paso de las mulas que solían transportar estos materiales. ${ }^{21}$ En las ciudades, las mujeres asumieron la administración, la protección y el sustento de la población. Su actividad en un principio fue de naturaleza puramente asistencial y consistió en una extensión de los roles tradicionales que habían venido desempeñando y que pasaron del ámbito particular del hogar y la familia al ámbito general y más extenso de los pueblos y ciudades y de la población civil. Esta labor, sin embargo, no debe subestimarse, pues era completamente necesaria y fue determinante para la protección y la supervivencia de muchos colectivos en situación de vulnerabilidad, como los niños y los ancianos.

rezou, y en un principio de dedicó al dar aliento a los soldados mediante cartas y envíos de pequeños paquetes con comida u objetos de utilidad en el frente. No obstante, hacia 1939, cuando el estallido de la guerra parecía ya inminente, empezó a desarrollar una importante actividad destinada a dotar al ejército de una indumentaria adecuada al clima y a la oro-

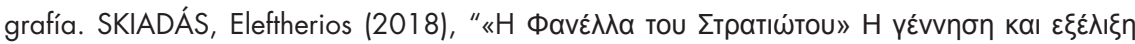

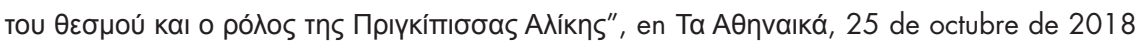
[https://www.taathinaika.gr/i-fanella-tou-stratiotou/].

18 Los uniformes del ejército griego eran de la Primera Guerra Mundial con polainas y botas que no se adecuaban al terreno montañoso donde se combatía. Había además una gran escasez

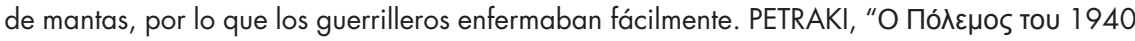
бта $\mu \varepsilon т о ́ т ı \sigma \theta \varepsilon v^{\prime \prime}$.

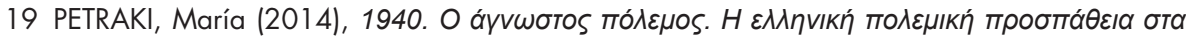

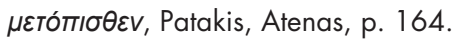

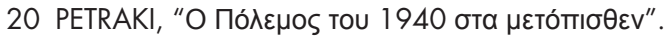

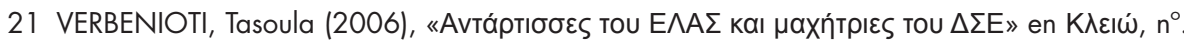
3, Epikentro, Tesalónica, p. 163. 
Lo más urgente e inmediato era alimentar a la población, sobre todo durante el periodo de la gran hambruna del invierno de 1941 y $1942 .{ }^{22}$ Una de las primeras iniciativas llevadas a cabo en Atenas para intentar paliar esta situación fue la institución Vida al niño, ${ }^{23}$ que consistió en organizar un sistema de atención a los niños, de modo que cada familia pudiente del barrio de Plaka se encargara de dar al menos una comida diaria a un niño. Este sistema fue concebido por un grupo de mujeres del ateniense barrio de Plaka, encabezado por loanna Tsatsos ${ }^{24}$ y funcionó durante todo el periodo de hambruna en Atenas. La propia loanna Tsatsos, se encargó poco después, y con el amparo del Arzobispado de Atenas, de poner en marcha el primer comedor público. ${ }^{25}$ Poco a poco y también por iniciativas individuales o colectivas de mujeres, se fueron abriendo comedores públicos en otras ciudades y pueblos de toda Grecia. El abastecimiento de estos comedores se hacía por medio de colectas o de intercambios. En Euritania, por ejemplo, las jóvenes que se ocupaban del comedor preparaban representaciones teatrales, para asistir a las cuales pedían al público que

22 Tras la entrada de los alemanes, las reservas de alimentos y las materias primas de Grecia, así como sus principales fuentes de ingresos habían sido requisadas como botín de guerra, de manera que la población griega quedó rápidamente desabastecida. Los productos de primera necesidad que se producían en Grecia eran trasladados a Alemania o acababan en el mercado negro. Esta situación acabó causando, pocos meses después de la entrada de los alemanes, la total devaluación de la moneda e imponiendo el sistema del trueque. La consecuencia más grave de todo ello fue, sin duda, la gran hambruna que se desató y que se cobró unas 300.000 víctimas en el invierno de 1941 y 1942. VAKALÓPULOS, Historia de Grecia, p. 322; GASPARINATOS, 'H Katoxń, pp. 46-56; y CONDOGEORGIS, Histoire de la Grèce, p. 406.

23 Esta institución estuvo presidida por loanna Tsatsos y constituida por Rita Liambei como secretaria, Irini Tsimbuki, Alexandra Miloná, Irini Jrisikopoulou, Lena Zaná, Miranda Ikonomou, Pan-

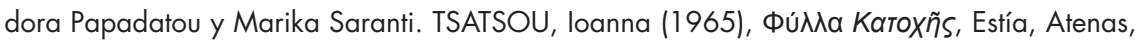
p. 32.

24 loanna Tsatsos era hermana del poeta Georgios Seferis. Nació en Esmirna en 1902 y se trasladó a Atenas con su familia en 1914. Tras la ocupación de Grecia por las fuerzas del eje, llevó a cabo actividades de apoyo a la Resistencia como facilitar la huida de oficiales aliados o trasladar información entre sus miembros. Junto con su marido Constantinos Tsatsos, colaboró estrechamente con la agrupación EKKA, así como con el coronel loannis Tsigantes. Llevó a cabo también una importante labor social y humanitaria en colaboración con el arzobispo de Atenas Damaskinós. En 1965 publicó su obra Diario de la Ocupación, un interesante documento sobre ese periodo de la historia de Grecia. GARCÍA AMORÓS, Maila, Autobiografía e historia en la obra de loanna Tsatsos, Universidad de Granada, Granada, 2008.

25 TSATSOU, Фú $\lambda \lambda \alpha$ Katoxñ , р. 30. 
llevara alubias o maíz para abastecer los comedores en lugar de pagar una entrada. ${ }^{26}$

No podemos dejar de hablar en este punto de la importante labor humanitaria llevada a cabo en el seno del Arzobispado de Atenas, donde se desarrolló una intensa actividad de apoyo a las familias. Tras los primeros fusilamientos, que empezaron en Grecia el 5 de octubre de 1941, pronto se hizo evidente la situación de indefensión y de necesidad en la que quedaban sus familias. ${ }^{27}$ De esta manera, el arzobispo Damaskinós concibió la idea del Servicio de Asistencia a las Familias de los Ejecutados, que empezó a funcionar en marzo de 1942. Damaskinós ${ }^{28}$ delegó la dirección del Servicio en loanna Tsatsos, quien a su vez se rodeó de un grupo de mujeres que lo gestionó durante toda la Ocupación. ${ }^{29}$ Este servicio consistía en llevar un minucioso registro de las personas que ingresaban en prisión y de aquellas que eran ejecutadas, con la finalidad de poder facilitar la información necesaria a las familias. ${ }^{30}$ El objetivo último, no obstante, era establecer un sistema de pensiones para las familias de los rehenes y de los ejecutados. De esta manera, en un principio, el Arzobispado dio cober-

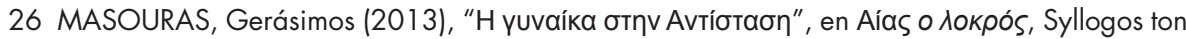
en Athinais kai Apantaxou Martinaion, n' 33 [http://www.martino.gr/images/pdf/AIAS_33. pdf) (última consulta 07 de julio de 2019).

27 La situación de necesidad en que quedaban las familias y la tremenda hambruna de 1941 empujaron a muchas mujeres a la prostitución. Como sucedió también en otros países ocupados, aquellas que ofrecieron sus servicios a soldados $u$ oficiales alemanes o italianos pagaron tras la Ocupación un precio muy caro, la exclusión social y el escarnio público, entre otros

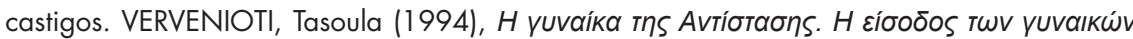

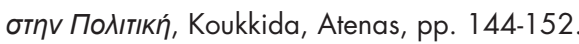

28 Dimitrios Papandreou nació en Ełolia en 1891. Se ordenó sacerdote en 1917, adoptando el nombre de Damaskinós. Fue nombrado arzobispo de Atenas tras la entrada en Grecia de las fuerzas del Eje. Al frente de este cargo llevó a cabo una importante actividad en favor de las víctimas de la Ocupación y de los judíos, por lo que fue declarado uno de los «Justos entre las Naciones». Al finalizar la Ocupación ejerció el cargo de Primer Ministro en funciones.

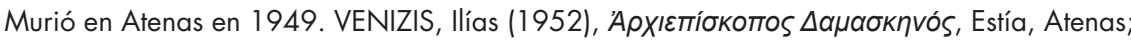

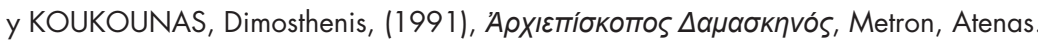

29 Entre estas mujeres se encontraban Lilika Teotokás, Anna Alevrás, Sosó Stupatis, Lula Trilivas, María Kútsikos y María Papadakis. TSATSOU, Фú $\lambda$ a Katoxñs, p. 85.

30 La lista de ejecutados elaborada por loanna Tsatsos sirvió como prueba en los Juicios de Nuremberg y se publicó en 1947 con el título de Ejecutados durante la Ocupación. TSATSOU,

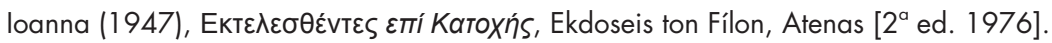


tura económica a numerosas familias atenienses. Algo más tarde, a partir de 1943, estas pensiones empezaron a concederse de manera legal ${ }^{31}$ y pudieron llegar a muchas familias de las provincias. El dinero se obtenía a través de colectas organizadas por el grupo de mujeres a cargo del servicio. ${ }^{32}$ La concesión de estas ayudas molestaba tremendamente a los mandos italianos, quienes sospechaban que el arzobispo estaba recibiendo dinero de Oriente Medio. En 1943, el propio Damaskinós fue sometido a arresto domiciliario y loanna Tsatsos fue llamada a un interrogatorio, del que pudo salir indemne. ${ }^{33}$

Dentro de la labor humanitaria llevada a cabo por el Arzobispado, no podemos dejar de aludir a sus esfuerzos por salvar a la población judía. Cuando el 17 de abril de 1943 comenzó la persecución de judíos en Grecia, con la noticia de que todo hebreo que no fuera de origen griego debía marcharse a su país y que los hebreos griegos debían marchar a Polonia, Damaskinós, junto con 27 representantes políticos y académicos, firmó una carta en la que se hablaba de «los griegos de la comunidad judía» y defendía que éstos debían ser considerados griegos sin distinción alguna de raza o de religión. loanna Tsatsos, que estuvo en esos momentos al lado del arzobispo, da testimonio de los certificados de nacionalidad griega falsos y de las partidas bautismales que entregaban a los judíos a fin de hacerlos pasar por griegos ortodoxos. ${ }^{34}$

En relación con las iniciativas de socorro a las víctimas de la Ocupación, hemos de destacar la labor desempeñada por la organización Solidaridad Nacional, que estuvo funcionando desde el principio de la Ocupación y en la que participaron mujeres de todos los lugares del país. Solidaridad Nacional surgió por inspiración del EAM y se fundó en mayo de 1941. En sus comienzos se dedicó a ofrecer apoyo y facilitar la huida a los griegos perseguidos, a organizar visitas a las prisiones para llevar ropas y alimentos a los presos y a paliar los efectos de la hambruna de 1941-1942. Paulatinamente, la agrupación fue ampliando su campo de actuación y empezó a prestar también servicios médicos y educativos. De esta manera, se fundaron hospitales para la atención de los soldados heridos, pero también de la población civil, así como guarderías y escuelas para garantizar la educación durante este periodo, principalmente en las zonas rurales. ${ }^{35}$

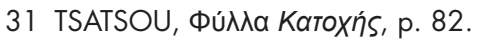

32 TSATSOU, Фú $\lambda$ a Katoxńs, p. 72.

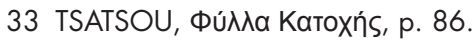

34 De los 62.700 hebreos que vivían en Grecia antes de la Ocupación, sobrevivieron tan sólo 10.000 .

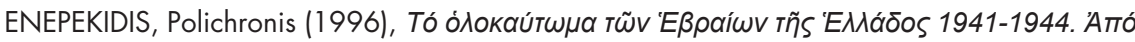

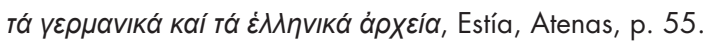

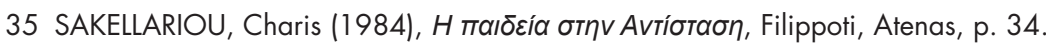


La Solidaridad Nacional se extendió rápidamente por toda la geografía griega, desde las ciudades más importantes, hasta los pueblos más remotos y estaba integrada en su inmensa mayoría por mujeres. La participación en la Solidaridad Nacional estaba relativamente bien considerada por la sociedad, porque se veía como el modo más adecuado en que una mujer podía contribuir a la lucha, ya que podían hacerlo sin salirse de sus roles tradicionales. La organización alcanzó su mayor número de participantes el último año de la Ocupación, hecho que se ha asociado precisamente a la revalorización del papel de la mujer. ${ }^{36}$ Hay que añadir, no obstante, que para colaborar con esta organización, las mujeres tuvieron que superar numerosos prejuicios, no sólo por parte de los hombres y de la sociedad en general, sino también por parte de las propias mujeres de otras generaciones que no comprendían su participación en la lucha.

\section{Participación de las mujeres en la resistencia}

Conforme se prolongaba la Ocupación, las mujeres fueron involucrándose de manera cada vez más activa en la lucha por la liberación y participando en actividades tradicionalmente restringidas a los hombres. Fueron muchas las que, abandonando sus hogares y rompiendo, en muchas ocasiones, los lazos familiares, ${ }^{37}$ se enrolaron en diversas agrupaciones de la Resistencia. Como ya señalamos al comienzo, el EAM era, con diferencia, la agrupación más fuerte de la Resistencia. Hacia finales de 1941 se había creado su brazo militar, el ELAS, que en diciembre de 1942 se había extendido ya por gran parte de Grecia y en cuyas filas fueron enrolándose rápidamente no sólo partisanos de ideología comunista, sino también muchos otros de otras ideologías. El EAM, a pesar de su actitud hostil hacia otras agrupaciones de la Resistencia, ${ }^{38}$ contó con un enorme apoyo popular que se granjeó gracias a sus promesas de un futuro más halagüeño para las gentes de las áreas rurales, para los jóvenes y para las mujeres. ${ }^{39}$ Del EAM surgieron dos

36 VERVENIOTI, H yuvaíka tns Avtíotaons, p. 229.

37 No fueron pocas las mujeres de familias acomodadas y conservadoras que se enrolaron en agrupaciones de Resistencia de izquierdas, lo que provocaba, en la mayoría de los casos, una enorme brecha en sus relaciones familiares.

38 Representativos de la actitud hostil del ELAS con los otros grupos de Resistencia son los numerosos ataques perpetrados contra ellas, como el de octubre de 1943 contra el EDES o los continuos ataques contra la EKKA, provocando su desintegración en varias ocasiones y que culminarían con el asesinato de su líder, Dimitrios Psarós el 17 de abril de 1944. Estos ataques ponían en evidencia su fuerte deseo de hacerse con el poder político una vez terminada la guerra. CLOGG, Historia de Grecia, p. 220; PAPAGIANNÓPOULOS, 5/42$\theta$ oúlos, p. 84; y CONDOGEORGIS, Histoire de la Grèce, p. 408.

39 CLOGG, Historia de Grecia, p. 128. 
agrupaciones de juventudes que en sus comienzos disgregaron a hombres de mujeres. Así, la agrupación Joven Libre estaba constituida exclusivamente por mujeres, mientras que el EAM Joven estaba formado únicamente por varones. Ambas agrupaciones terminarían confluyendo en febrero de 1943 en una sola que se llamó EPON. ${ }^{40}$

Joven Libre, cuyo nombre revelaba claramente tanto las promesas del EAM con respecto a la emancipación como las expectativas de las jóvenes que se incorporaban a la agrupación, se gestó en el ámbito universitario y brindaba a sus jóvenes integrantes la oportunidad de cambiar su modo de vida y de asumir nuevas responsabilidades más allá de aquellas a las que parecían estar destinadas. No hay que olvidar que hablamos, en la mayoría de los casos, de mujeres que provenían de familias conservadoras -las familias que podían costear estudios a sus hijas eran también las más conservadoras de la sociedad-sujetas a tradiciones ancestrales que mantenían a la mujer atada al matrimonio y al cuidado del hogar y de los hijos. La agrupación fue creciendo en número de integrantes y extendiéndose por las provincias incluyendo en sus filas a mujeres de toda Grecia, que deseaban contribuir a la lucha y reivindicar, de este modo, que también ellas eran capaces de organizarse y de emprender acciones por la liberación de la nación. La agrupación estuvo dirigida por un importante miembro de la Resistencia, Electra Apostolou (1912-1944), responsable también de la elaboración del material propagandístico ilegal del Partido Comunista, lo que le costó ser apresada y ejecutada por miembros de la Seguridad Especial Griega $^{41}$ en julio de 1944. La participación de la mujer en actos de resistencia asociados a esta agrupación fue activa y consistía fundamentalmente en hacer pintadas en las calles o repartir propaganda ilegal, transportar armas y alimentos o transmitir información y mensajes. Algunas, como es el caso de Hero Constantopoulou participaron también en actos de sabotaje. Además de la agrupación Joven Libre, en Atenas operaba también la orga-

40 En el EPON (Organización Panhelénica Unida de Juventudes) terminarían por confluir también numerosas organizaciones de Resistencia nacionales y regionales que decidieron la desintegración de todas ellas para formar una sola organización.

41 La Dirección de Seguridad Especial del Estado, más conocida como Seguridad Especial, era un ala de las Fuerzas de Seguridad griegas creado en 1929 con objeto de perseguir las organizaciones comunistas. Durante la Ocupación colaboró estrechamente con las fuerzas de Ocupación y participó en detenciones, torturas y ejecuciones de miembros de la Resistencia griega. Fue desintegrada en septiembre de 1944. GEORGÍOU, Vasos (ed.) (1979), Iбторía ins Avtíotaons 1940-45, Aulós, Atenas, p. 1442. 
nización de sabotaje PEAN, ${ }^{42}$ que registró una alta participación femenina. Digno de mención es el caso particular de loulía Bimba (†1943), una sencilla empleada de hogar ${ }^{43}$ procedente de Samos, quien tras ingresar en el PEAN, ofreció su casa como taller para la fabricación de bombas. Ella misma fue la encargada de transportar hasta el centro de Atenas y de colocar la bomba de 10 kilos con la que se voló la sede de la ESPO ${ }^{44}$ en diciembre de 1942. Este hecho es considerado uno de los más importantes actos de sabotaje infringidos al enemigo. loulía Bimba fue apresada junto con otros miembros de la organización y ejecutada a principios de 1943. En relación con la participación de la mujer en la Resistencia, no se puede dejar de hablar de Eleni Karagianni (1898-1944), más conocida con el hipocorístico de Lela, considerada una de las grandes figuras de la Resistencia griega. Lela Karagianni creó y lideró una de las primeras agrupaciones de Resistencia que empezaron a operar en Grecia y la llamó Bubulina. ${ }^{45}$ Se trataba de una pequeña, pero sumamente eficaz organización, integrada por unas 150 personas, cuyo núcleo lo conformaban ella misma, su marido Nikólaos Karagiannis y sus siete hijos. La organización se dedicó principalmente a facilitar la huida de oficiales británicos atrapados en la

42 El PEAN (Unión Panhelénica de Jóvenes Cambatientes) fue una pequeña organización de la Resistencia constituida por pocos miembros y dedicada al sabotaje. Estaba dirigida por Constantinos Perikos y era de inspiración progresista y socialista. Entre sus golpes más importantes destaca la explosión de la sede del ESPO. LIMPERATOS, Michalis (2007), Oı opyavẃozıs thS Avtíotaons, t.III, parte II, Vivliorama, Atenas, p. 50; y HATZIVASILÍOU, Evanthis (2004), ПEAN

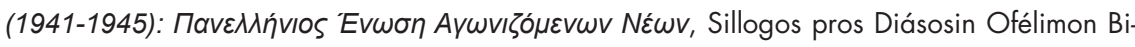
blion, Atenas, p. 114.

43 Aunque loulía Bimba es conocida como "la maestra de la Resistencia", en realidad no era maestra. No obstante, durante la Ocupación impartía clases en su tiempo libre en la escuela de San Nicolás, de ahí que se la conozca con este apelativo. VATAKIS, Pantelís, LAGÓS,

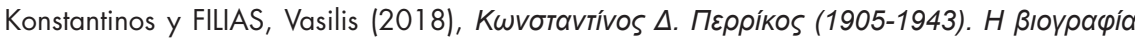
Evós ńpwa, Menandros, Atenas, p. 654.

44 La ESPO (Organización Nacional Socialista y Patriota) había sido creada por los alemanes con la finalidad de enrolar a griegos y crear un pelotón colaboracionista que luchara contra Rusia del lado de los alemanes. GASPARINATOS, 'H Катохи́, p. 238

45 El nombre elegido era el de la célebre heroína de la Guerra de la Independencia griega Laskarina Bubulina (1771-1825) que, al mando de su propio buque, el Agamenón, sembró el terror entre la flota otomana en el Mar Sarónico. No en vano, además, Lela Karagianni era bisnieta de Laskarina Bubulina. Para más información sobre Lela Karagianni y la agrupación Bubulina

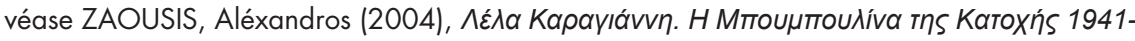
1944, Okeanida, Atenas. 
Grecia Ocupada. ${ }^{46}$ Es preciso señalar que la ayuda, que los miembros de la Resistencia ofrecían a los aliados, los ponía en serio peligro, sobre todo a partir del 8 de diciembre de 1941, cuando los alemanes comenzaron a aplicar una nueva ley, según la cual, quien fuera descubierto escondiendo o prestando auxilio a los ingleses sería ejecutado. ${ }^{47}$ Lela Karagianni fue, de hecho, detenida acusada de estar escondiendo a oficiales aliados y pasó siete meses en prisión antes de ser liberada por falta de pruebas. Al poco de ser liberada retomó su actividad al mando de la agrupación. Con recursos propios, se hizo con cuatro barcos en los que trasladaba clandestinamente, no sólo a oficiales aliados, sino también a griegos perseguidos y a judíos cuando empezaron las persecuciones en Grecia. La agrupación Bubulina tendió, además, una importante red de espionaje. Lela Karagianni poseía una personalidad increíblemente carismática y logró granjearse la colaboración y el apoyo de algunos oficiales alemanes e italianos contrarios al nazismo. El objetivo de esta red de espionaje era, entre otros, recabar información sobre los movimientos de los buques alemanes, sustraer planos de aeropuertos y transmitir a sus colaboradores información sobre los mandos de la Ocupación. La agrupación tenía también contacto con agentes del ejército aliado en Oriente Medio. A partir de 1943, empezó a prestar su colaboración a la organización de sabotaje APOLON. ${ }^{48}$ En julio de 1944 fue traicionada y detenida, para ser ejecutada poco después, tan sólo un mes antes de la retirada de las tropas alemanas de Grecia. Lela Kariagianni coincidió en prisión con la jovencísima Hero Constantopoulou (1927-1944) de 17 años, miembro de la agrupación EPON, que había sido detenida por su participación en la explosión de un tren que transportaba armamento alemán. Aunque pertenecían a agrupaciones de distinta ideología, entre ambas surgió una fuerte relación de amistad. Hero Constantopoulou fue ejecutada tres días más tarde que Karagianni.

La participación de las mujeres en la Resistencia no se limitó a la capital griega, sino que también en las provincias se emprendieron iniciativas, ya en el seno de las agrupaciones existentes, ya a nivel particular, como fue el caso de María Dimadi que merece la pena mencionar. María Dimadi (1907. 1944) procedía de una familia acomodada de Agrinio, en Etolo-Acarnania,

46 Aunque el contingente británico había sido evacuado con el gobierno en abril de 1941, meses más tarde todavía quedaban muchos oficiales ingleses dispersos que no habían podido huir antes de la entrada de las tropas alemanas.

47 VAKALÓPULOS, Historia de Grecia, p. 325.

48 La organización de sabotaje APOLON se dedicó a volar buques enemigos hacia finales de

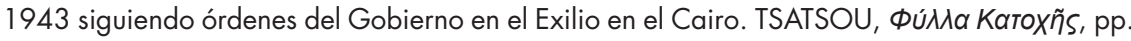
$119-121,166,167$ y 173. 
y había recibido una formación esmerada, por lo que dominaba varias lenguas, entre ellas, el alemán. Cuando los alemanes entraron en Agrinio y pidieron un intérprete, María Dimadi acudió voluntaria, lo que le dio acceso a mucha información sobre la estrategia militar alemana en la zona. María sacaba la información del cuartel alemán en las hojas de carboncillo que utilizaba para hacer las copias de los documentos que mecanografiaba. A través del pope de la ciudad, Constantinos Papavalis, que hacía de enlace, estos documentos oficiales llegaban hasta los guerrilleros y miembros de la Resistencia de la zona de Agrinio. Fue de esta manera como la Resistencia (el ELAS), informada del ataque sorpresa que los alemanes preparaban en la zona, pudo organizarse, atajar el ataque e infringir un daño importante al enemigo el 10 de julio de 1943. Esta fue, de hecho, la primera empresa exitosa de la Resistencia griega en la zona de Agrinio. Tras estos hechos, María pasó a estar en el punto de mira, no sólo de los alemanes, sino también de los Batallones de Seguridad, ${ }^{49}$ quienes finalmente la apresaron y la ejecutaron. ${ }^{50}$

\section{LAS PARTISANAS}

En la lucha por la liberación no faltaron tampoco mujeres que, tras recibir instrucción militar, se incorporaron como oficiales a las filas de guerrilleros y combatieron junto a ellos tomando parte en los ataques de las guerrillas. El ELAS había creado una Escuela de Oficiales en la que en 1941 había matriculados 350 hombres y 2 mujeres. Sin embargo, hacia el final de la guerra, el número de mujeres matriculadas había ascendido a 65 . Entre las filas del ELAS se encontraban 13 mujeres que se habían licenciado en la Escuela de Oficiales de Rentina con el grado de subteniente y que se hacían cargo de la gestión de los pelotones de mujeres. ${ }^{51}$ Hay que señalar, en este punto, que pasar a formar parte de las filas de partisanos del ELAS

49 Los batallones de seguridad se crearon en abril de 1943 y eran unidades militares integradas por voluntarios griegos y armadas por Alemania con el fin de combatir a los grupos de guerrilleros del EAM. Los primeros voluntarios eran gentes sin recursos que trataban así de evitar ser enviados a Alemania, criminales o miembros amenazados por la Resistencia. Empezaron a crecer, sobre todo, tras la rendición italiana en septiembre de 1943. Los Batallones de Seguridad colaboraron en el traslado de judíos griegos a Auschwitz y en general sembraban el terror entre la población civil, ya que junto a la Seguridad Especial tomaban rehenes que eran ejecutados como represalia de los ataques de la Resistencia. MAZOWER, Mark (1995), Inside Hitler's Greece: The Experience of Occupation (1941-44), Yale University Press, New Haven, pp. 334-358.

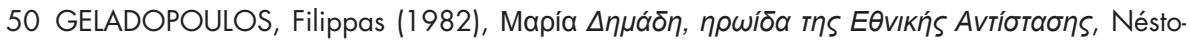
ras, Atenas.

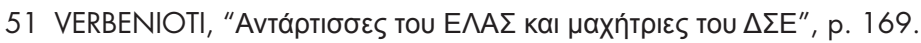


no resultaba fácil para las mujeres, ya que además de la autorización de los mandos del propio ejército del ELAS, necesitaban una autorización paterna. Evidentemente muchos padres se negaban a mandar a sus hijas a la guerra. Para ser consideradas partisanas necesitaban, además, disponer de su propia arma, cosa que tampoco resultaba fácil, pues el ejército no proporcionaba armas a mujeres. La mayoría de ellas tuvieron que procurarse su propia arma. ${ }^{52}$ Es paradigmático el caso de Melpómene Papailíou, apodada Thyela (tempestad), que portaba una automática y unos pantalones que le había quitado a un soldado alemán al que había dado muerte. En un primer momento, las guerrilleras participaron de manera desorganizada junto con los hombres. Posteriormente se fueron organizando en pelotones constituidos exclusivamente por mujeres. Estas mujeres guerrilleras se convirtieron así en una especie de propaganda para la exhortación a la lucha, pues constituía una forma de demostrar que podían actuar $y$, por lo tanto, que las gentes de los pueblos (hombres y mujeres) podían sumarse también a la lucha contra el invasor. Este tipo de propaganda servía además para tratar de lavar el nombre del EAM, tras sus numerosos ataques contra agrupaciones de Resistencia no comunistas.

La actividad de las guerrilleras que integraban los pelotones estaba muy unida a la de los jóvenes guerrilleros del EPON. Sus obligaciones eran militares, políticas y culturales. Evidentemente, tomaban parte en las batallas junto con los hombres, se hacían cargo de la vigilancia de la División, hacían rondas en los pueblos e informaban a las gentes sobre el avance de la guerra. Las guerrilleras colaboraban también organizando representaciones culturales, teatros, bailes, etc. y a la vez recogían provisiones. Una vez creado el EPON en 1943, no hubo disgregación de género y hombres y mujeres convivían como iguales, lo cual pronto creó un fuerte espíritu de camaradería entre ellos. Existía, no obstante, una ley no escrita, según la cual no podían establecer relaciones amorosas entre ellos hasta que no terminara la guerra..$^{53}$ En el material fotográfico conservado de aquella época puede verse a las jóvenes partisanas con el cabello recogido a fin de no constituir una provocación para sus compañeros varones. Esta norma se mantuvo con mucha disciplina y severidad, tanto es así, que en la División 13 expulsaron a una muchacha por considerar que su belleza constituía una provocación para los oficiales del ejército local. Así mismo, en septiembre de 1944 en una zona recién liberada, una guerrillera fue acusada de mantener relaciones sentimentales con un hombre y condenada a deponer 
el arma. La condena suponía un agravio tan grande, que la muchacha se suicidó con su propia arma antes de que se la quitaran. ${ }^{54}$

Aunque la participación de las mujeres en las guerrillas se ha asociado normalmente a convicciones de izquierdas, ${ }^{55}$ es preciso señalar que no todas estas mujeres -ni tampoco todos los hombres- abrazaban ideales comunistas, sino que una gran parte de sus integrantes se enrolaban por considerar que era una forma de luchar contra el invasor de manera organizada, independientemente de sus ideas políticas. ${ }^{56}$ Así pues, las mujeres veían en el EAM una forma de abandonar los roles tradicionales a los que estaban sometidas y de emanciparse en una sociedad que, sobre todo en las zonas más rulares, era todavía acusadamente patriarcal. ${ }^{57} \mathrm{~A}$ pesar de ello, muchos de ellos, hombres y mujeres, sufrieron persecuciones y castigos al terminar la guerra y sobre todo tras la derrota comunista en la guerra civil griega que sucedió a la Ocupación. ${ }^{58}$

\section{Conclusiones}

Es muy importante hacer énfasis en que la participación de la mujer en la Resistencia les brindó la oportunidad de asumir nuevos roles y de sentirse no sólo partícipes en la lucha por la liberación de la nación, sino también de su propia liberación. De esta manera, las mujeres emprendieron iniciativas, empezaron a tomar decisiones propias, a reafirmar su autoestima y a desarrollar una nueva identidad femenina, que adquirió nuevas dimensiones: la de combatiente, la de mujer que asume la administración y la gestión de las ciudades y de los servicios, la de quien tiene en su mano salvar la vida de otras personas. Fue de este modo como se hizo patente que las mujeres desempeñaban un importante papel en la vida de un estado. A través de su participación en la Resistencia las mujeres adoptaron, además, conciencia política, de una u otra ideología, y poco a poco fueron asumiendo responsabilidades. Su participación en las decisiones políticas se fue normalizando, no en vano durante la Ocupación las mujeres participaban de las decisiones y votaban igual que los hombres. La primera vez que las mujeres ejercieron su derecho el voto en Grecia fue en las votaciones celebradas en abril de 1944 para la creación de un Consejo Nacional en las zonas de Grecia controladas por el EAM. ${ }^{59}$ Todo ello acabaría abrien-

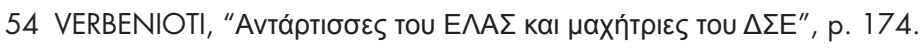

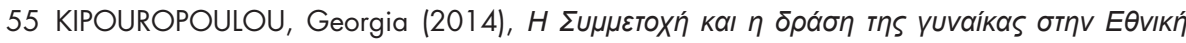

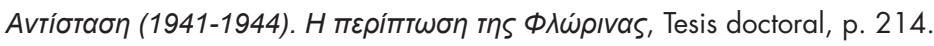

56 VAKALÓPULOS, Historia de Grecia, p. 326.

57 CLOGG, Historia de Grecia, p. 123. 
do finalmente el camino a su emancipación social y al reconocimiento de su derecho al voto en 1956.60

La mujer, no obstante, tendría que superar otro duro obstáculo antes de poder emanciparse y ejercer sus derechos en plena libertad: la guerra civil griega (1946-1949), que dividió al país durante más de tres años y que trajo unas consecuencias funestas. ${ }^{61}$ No cabe ahora detenerse en el papel que desempeñó la mujer en esta otra guerra, la mayoría de ellas, no obstante, siguieron desarrollando actividades parecidas a las que habían estado desarrollando durante la Ocupación, en el marco ahora, de una confrontación civil, con todas las implicaciones que este hecho conlleva. ${ }^{62}$ Podemos afirmar, a modo de conclusión que, con la participación de la mujer en las diversas formas de Resistencia, se superaron numerosas dudas y prejuicios que imperaban en la sociedad hasta ese momento y que las mujeres lograron ganarse en parte el respeto de sus compañeros masculinos abriendo así el camino hacia su emancipación social y su participación política. Durante este difícil momento de la historia de Grecia, habían demostrado con creces que eran capaces de hacerse cargo de la administración de las ciudades, de la protección de las familias, que eran capaces también no sólo de colaborar en actos sabotaje, sino también de crear y dirigir organizaciones de Resistencia y redes de espionaje y finalmente, que eran capaces de luchar al lado de los hombres empuñando su propia arma. En esos momentos, ya nadie podía dudar de la igualdad entre hombres y mujeres, era una igualdad de facto.

58 Precisamente la política vengativa del Partido Popular, vencedor en las primeras elecciones libres tras la Ocupación, acrecentó la crispación política y culminó con la formación de un ejército comunista llamado Ejército Democrático, liderado por Markos Vafiadis, antiguo líder del ELAS, y el estallido de la Guerra Civil Griega, que se prolongó hasta 1949, con la derrota del Ejército Democrático, gracias a la colaboración de los Estados Unidos. MAZOWER, Mark (2000), After the war was over, Princeton University Press, Princeton; y RIZAS, Sotiris (2011),

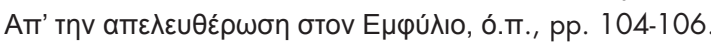

59 CLOGG, Historia de Grecia, p. 128.

60 VERVENIOTI, H yuvaíka ths Avtíotaons, pp. 260-270.

61 Además de las pérdidas humanas, la Ocupación y la posterior guerra civil dejaron al país en una situación lamentable. La marina mercante quedó totalmente destrozada, así como la producción agrícola e industrial y gran parte de las infraestructuras. También fueron arrasados pueblos enteros, de manera que al final de la guerra había cerca de 1.200 .000 personas $\sin$ hogar. CONDOGEORGIS, Histoire de la Grece, pp. 414-415.

62 Muchas de las mujeres guerrilleras pasaron entonces a las filas del Ejército Democrático Grie-

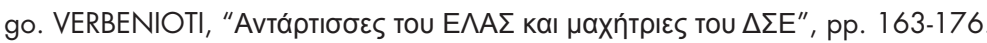





\title{
LAS DINÁMICAS DE GÉNERO EN LAS BRIGADAS FEMENINAS DE LA GUERRA SIRIA
}

\section{GENDER DYNAMICS IN THE WOMEN'S BRIGADES OF THE SYRIAN WAR}

\author{
Isabel García \\ Universidad Nacional de Educación a Distancia
}

\section{RESUMEN}

Tras el estallido de la guerra siria en el año 2011 varios grupos que se dan cita en el contencioso crearon sus propias brigadas femeninas, consiguiendo una rápida proyección internacional y un interés inusitado por los medios de comunicación de masas. Este artículo contribuye a explicar este repentino aumento de mujeres combatientes dentro del contexto del país árabe. Para ello se llevará a cabo una comparación entre los cuatro principales grupos que se dan cita en la guerra: Daesh, el Ejército Libre Sirio, las Unidades de Protección Popular y las fuerzas gubernamentales. El artículo aborda la ideología de género de estas organizaciones y explica las posibles razones que les han llevado a contar con presencia femenina en sus filas.

Palabras clave: mujer, género, Siria, guerra, terrorismo.

\begin{abstract}
After the outbreak of the Syrian war in 2011 , several groups created their own women's brigades. As a result, there was a rapid rise in the international coverage and an unexpected interest from the mass media. The aim of this article is to shed light on this phenomenon within the context of the Arab country. To that end this, the research will make a comparison between the four main groups in the war: Daesh, the Free Syrian Army, the Syrian Kurdish Force and the Assad regime. Finally, the article deals with the gender ideology of these organizations and explains the possible reasons which have led them to have a female presence in their ranks.
\end{abstract}

Keywords: women, gender, war, Syria, terrorism. 


\section{RESUM \\ LES DINÀMIQUES DE GÈNERE A LES BRIGADES FEMENINES DE LA GUERRA A SIRIA}

Després de l'esclat de la guerra siriana l'any 2011 diversos grups que es donen cita en el contenciós crearen les seues pròpies brigades femenines, aconseguint una rápida projecció internacional i un interès inusitat pels mitjans de comunicació de masses. Aquest article contribueix a explicar aquest augment sobtat de dones combatents dins del context del país àrab. Amb la qual cosa, es durà a terme una comparació entre els quatre principals grups que es donen cita a la guerra: Daesh, I'Exèrcit Lliure Sirià, les Unitats de Protecció Popular i les forces governamentals. L'article aborda la ideología de gènere d'aquestes organitzacions i explica les possibles raons que els han portat a comptar amb presència femenina a les seves files.

Paraules clau: gènere, Siria, guerra, terrorisme. 
Las mujeres han participado a lo largo de la historia en diferentes conflictos armados y pese a que, generalmente, su actuación ha estado relegada a la retaguardia, existen ejemplos de mujeres que tuvieron una parte más activa en el combate. Algunas de estas pioneras figuras de la época contemporánea fueron las francotiradoras soviéticas o las mujeres británicas que sirvieron como pilotos durante la II Guerra Mundial (VINOGRADOVA, 2017; YEGINSU, 2018). Tampoco se quedaron atrás las mujeres que participaron en las diferentes luchas anticoloniales, siendo el caso de Argelia uno de los más reconocidos (DJAMILA y ABU-HAIDAR, 1999: 62). Sin embargo, el papel de estas ha ido evolucionando en función de la cultura propia del entorno donde se disputaba la acción y conforme las contiendas tradicionales iban dando paso a los conocidos como conflictos asimétricos. El rol que ha desempeñado la mujer en estas ofensivas se ha analizado desde diferentes perspectivas sin embargo, su contribución a la lucha armada sigue siendo desconocida pese a que su presencia es cada vez más relevante, sobre todo dentro de grupos insurgentes o de carácter terrorista. Así, El Ejército Rojo Japonés, ETA, Sendero Luminoso o Los Tigres de Liberación de Eemal Tamil (LTTE, por si siglas en inglés) son solamente algunos 
ejemplos de las organizaciones que han contado con mujeres entre sus miembros. No obstante, la gran mayoría de las investigaciones sobre el fenómeno han centrado su atención en los hombres, asumiendo que el papel que desempeñaban las mujeres era secundario (CUNNINGHAM, 2003).

Las primeras investigaciones en los años 70 y 80 pusieron su foco de atención en la participación femenina en la revolución rusa y en las guerrillas de América Latina. Una década después la comunidad científica amplió su atención de forma visible hacia las mujeres que eran miembros del IRA. Durante los años 90 solamente se publicaron dos libros que se adentraban en explicar la participación de mujeres en movimientos extremistas y las razones psicológicas y sociológicas que había detrás de su adhesión a los grupos (MCDONALD, 1991; DE CATALDO y TITIANA, 1992).

Es a partir del año 2000 cuando aumenta el número de publicaciones, fecha que coincide con la perpetración de actos terroristas suicidas por parte de mujeres de forma asidua. Se trata de uno de los temas que más ha preocupado a la comunidad internacional y hay varios autores que han tratado de estudiar esta emergencia en conflictos como Chechenia, Palestina o Irak (SPECKHARD, 2008; O'ROURKE, 2009). No obstante, hay una discrepancia patente sobre cuáles son las principales motivaciones que conducen a las mujeres a verse envueltas en actos violentos. Una de estas corrientes sostiene que la principal razón atiende a la vertiente personal y que los vínculos familiares, la pérdida de un ser querido o haber sufrido una agresión sexual son los motivos más recurrentes (VICTOR, 2004).

Esta relevancia dentro del campo académico por la mujer y la violencia volvió a despuntar tras el estallido del conflicto sirio gracias a la creación de diferentes brigadas femeninas. En 2013 la cifra de mujeres que se había unido a grupos rebeldes en la región se estimaba en 5.000 (SHOLMAN, 2013). La investigadora Sjoberg sostiene que la participación de las mujeres en el contencioso ha conseguido más cobertura mediática que la mayoría de las guerras civiles pero que aún se desconocen las motivaciones que han tenido para vincularse a los diferentes grupos dentro del conflicto (SJOBERG, 2018).

Este artículo contribuye a explicar este repentino aumento de mujeres combatientes dentro del contexto del país árabe. Para ello se estudian las razones que propiciaron el cambio a través de los cuatro principales grupos que se dan cita en el contencioso. Estas organizaciones son: Daesh, Unidades de Protección Popular (YPG, en sus siglas en kurdo), El Ejército Libre Sirio (ELS) y las fuerzas gubernamentales de Bashar al-Asad. Se han elegido estos grupos debido al interés mediático que han suscitado las mujeres de estas organizaciones, en especial las militantes de Daesh (SJOBERG, 
2018: 301). El artículo aborda, siempre que se cuente con información disponible, el papel beligerante de la mujer dentro de estos grupos y la ideología de género que estas organizaciones han trasladado a la opinión pública.

Resulta imprescindible señalar que la investigación se enfrenta con una importante dificultad a la hora de recopilar información ya que hay pocos estudios al respecto debido al reciente suceso de los acontecimientos. Se ha tratado de solventar esta problemática analizando la propaganda vertida por cada uno de los actores analizados, como las revistas oficiales de Daesh (Dabiq o Rumiyah). También han servido de base documental diferentes fuentes secundarias, bases de datos e informes de reputadas organizaciones internacionales como Freedom House, Naciones Unidas o Human Rights Watch. El artículo comienza con el estallido de la revolución y una aproximación a la situación de la mujer en la región antes y durante el inicio de las protestas.

\section{EL ESTALLIDO DE LA REVOLUCIÓN Y LA CONQUISTA DE NUEVOS ESPACIOS FEMENINOS}

El conflicto sirio estalló en el año 2011 al amparo de las manifestaciones populares conocidas como Primaveras Árabes. Pese al carácter pacífico y democrático que tuvieron las primeras protestas en el país, lo cierto es que poco a poco fueron derivando en una confrontación civil a gran escala. La población ha sido masacrada durante ocho años y se ha cobrado la vida de alrededor de 511.000 personas. Además, la violencia y el sectarismo característicos del conflicto han provocado el desplazamiento de casi siete millones de personas dentro de Siria y de más de cinco fuera de sus fronteras, desencadenando en una de las mayores crisis humanitarias que se recuerdan en pleno siglo XXI (HRW, 2018).

En este contexto de caos se han dado cita una gran diversidad de actores que no han hecho más que recrudecer la fragmentación social que impera en el país. Así, coexisten diferentes milicias armadas como el Ejército Libre Sirio (ELS), facciones como los peshmerga kurdos o las Unidades de Protección Popular (YPG). Estas, a su vez, disputan protagonismo con los dos principales grupos yihadistas que operan en la zona: Daesh y Jabhat al-Nusra, filial de Al Qaeda en Siria y recientemente bautizado con el nombre de Hayat Tahrir al-Sham (ÁLVAREZ-OSSORIO, 2016). Mientras, las fuerzas gubernamentales de Bashar al-Asad intentan recuperar el control de un territorio roto.

La reciente creación de brigadas femeninas por parte de estos grupos ha permitido a las mujeres escalar posiciones dentro de la esfera pública siria. Hasta ese momento dominada por los hombres, debido, en parte, a que la 
sociedad siria se rige por unas normas culturales bastante conservadoras (CHARLES y DENMAN, 2012: 205). Así, aunque la constitución garantiza la igualdad de género, lo cierto es que algunas leyes siguen perpetuando la discriminación femenina en la República árabe. Por ejemplo, aún en el año 2011 el régimen permitía penas indulgentes para los delitos cometidos en nombre del conocido como 'crimen de honor'. Además, en el país no se contempla el delito de violación dentro del matrimonio e incluso existe la posibilidad de que los violadores puedan casarse con su víctima para conmutar su pena (UNICEF, 2011).

No existe una brecha de género con respecto a la educación. El 92\% de las mujeres y el $97 \%$ de los hombres poseen estudios de educación primaria en el país (CHARLES y DENMAN, 2012: 204). Estas, además, representan el $46 \%$ del alumnado universitario aunque sus preferencias a la hora de elegir carrera siguen centrándose en campos asociados a la Educación y la Literatura. Los estudios vinculados con ingenierías o Medicina cuentan con menor presencia femenina (Freedom House, 2010). Estos datos de representación no se trasladan al mercado laboral (NASSER y MEHCHY, 2012: 2). Y es que un año antes de que estallaran las protestas, solamente el 12 , $9 \%$ de mujeres mayores de 15 años eran población activa. Los autores de dicho estudio sostenían que el matrimonio era un factor determinante para explicar dicha exclusión. ' No se trata de ninguna coincidencia, por tanto, que el país ostentara el puesto 124 de 135 países en el Índice Global de la Brecha de Género del año 2011 (HAUSMANN, TYSON y ZAHIDI, 2011). El estallido de la revolución rompió con tabúes arraigados en la sociedad siria y durante los primeros meses del levantamiento las mujeres participaron activamente en las protestas. ${ }^{2}$ Estas formaron parte de las demostraciones públicas, se organizaron alrededor de diferentes grupos como Syrian Women for the Syrian Intifada, establecieron redes para abastecer de ayuda humanitaria a la población civil (GHAZZAWI, 2014) e incluso denunciaron públicamente las atrocidades del régimen. Este fue el caso de la activista Razan Zaitouneh (CHARLES y DENMAN, 2012: 197), que se

1 Siria es uno de los países árabes que registra mayor tasa de matrimonios infantiles. Para más información consultar "A profile of child marriage in the Middle East and North Africa" (2016), Unicef.

2 Las mujeres sirias han estado involucradas en el activismo durante años y las organizaciones feministas tuvieron un considerable crecimiento durante la presidencia de Bashar al-Asad. Para más información sobre el tema consultar a Jeanne, 2015. 
vio obligada a vivir en la clandestinidad por temor a las represalias del régimen. Asimismo, fue una mujer, la abogada Muntha al-Atrash, la primera que se atrevió a pedir públicamente la dimisión del presidente sirio en abril de 2011 (JEANNE, 2017: 236). Este gesto sirvió de inspiración para muchas mujeres que con el incremento de la violencia y de la represión ejercida en numerosas ocasiones por parte del Estado, fueron adaptándose a las nuevas circunstancias del conflicto, asumiendo en algunos casos el rol de combatientes.

\section{LAS MILITANTES DE DAESH: LA NUEVA ERA DEL YIHADISMO FEMENINO}

Daesh es un grupo terrorista de carácter transnacional que propone, con unas técnicas depuradas y modernas, un modelo de Estado en el que son necesarios hombres y mujeres para su puesta en marcha. Su origen fundacional es Al Qaeda en Irak (AQI). Este grupo insurgente iraquí, que se encontraba en declive en el año 2011, ve una oportunidad de expansión en territorio sirio tras el estallido de la Primavera Árabe en la nación vecina. El grupo supo aprovechar el caos en el que estaba sumido Siria, así como el descontento de gran parte de la población de la zona rural con las políticas de Bashar al-Asad para ganar apoyos y apoderarse de un amplio territorio.

La organización consiguió una conquista relativamente rápida y en junio de 2014 Abu Bakr al-Baghdadi se autoproclamó líder de todos los musulmanes y anunció el establecimiento de un califato cuya capital se asentaría en la ciudad siria de Raqa. Desde entonces y hasta el año 2016, fecha en la que comienza su declive territorial, la organización llegó a controlar varias provincias de Siria e Irak y ciudades tan importantes como Mosul. El grupo gestionó esta región, compuesta por seis millones de habitantes, con un sistema administrativo bastante eficiente, fundamentado en su estricta interpretación de la sharía (AVILÉS, 2017: 176). Así, la organización impuso normas sociales de segregación por sexo, estableció estrictos códigos de vestimenta para las mujeres y prohibió escuchar música occidental o consumir alcohol. Bajo el califato también se instauró un mercado de esclavas sexuales cuyas víctimas fueron principalmente mujeres y niñas pertenecientes a la minoría yazidí. ${ }^{3}$

3 Los yazidíes pertenecen a una minoría religiosa preislámica. Hasta el siglo VII d.C fue la religión oficial de los kurdos. 
Daesh ha regulado su política de género a través de su aparato de propaganda y su visión con respecto a la violencia ejercida por las mujeres también ha quedado reflejada en su estrategia de comunicación. El artículo $A$ jihad withouth fighting (AL-MUHAJIRAH, 2015: 40-45) apunta de manera explícita que su ideal es que las mujeres deben estar alejadas del campo de batalla. No obstante, el grupo sostiene también a través de varios documentos que la violencia es una opción para las mujeres en caso de defensa propia o si no hay hombres suficientes para proteger el territorio del califato (WINTER y MARGOLIN, 2017: 26). Además, el grupo ensalza el valor de las musulmanas que ejercieron misiones suicidas en los casos de Irak y Chechenia.

El grupo se muestra tan abierto a que esta posibilidad surja que, incluso, creó al menos una escuela, al-Zawra, para proporcionar, entre otras labores, formación militar a las mujeres que integraban el califato (DAVIS, 2018). El Ejército Libre Sirio (ELS) también denunció la creación de un batallón compuesto por 200 mujeres cuyo objetivo era llevar a cabo misiones suicidas en los territorios controlados por el grupo. Existen pocos datos sobre mujeres que hayan llevado a cabo operaciones de martirio en nombre de Daesh pero al menos una mujer consiguió inmolarse en una base de las fuerzas kurdas en Kobane en el año 2014 (BBC monitoring, 2014). Este hecho fue posteriormente reivindicado por el grupo en la serie Stories of the Mujahideen (JAWAD AL-TAMIMI, 2017). Otra mujer tunecina fue detenida en el año 2014 portando un cinturón explosivo en Bab al-Hawa, cruce entre Siria y Turquía (BBC monitoring, 2014).

De ser ciertos, estos ataques no suponen una novedad en un grupo yihadista y están en consonancia con la línea iniciada por al-Zarqawi y con la que Daesh comulga. Resulta factible pensar que las actuaciones llevadas a cabo por estas mujeres respondían también a una necesidad del grupo debido a la zona donde se libraba la batalla y en la que Daesh contaba con menos recursos. Más innovadores son los datos recogidos por fuentes secundarias y que apuntan a que durante los primeros años de vida del califato las mujeres han podido frecuentar el campo de batalla. Se tiene constancia de que al menos una mujer de origen canadiense enviaba tuits desde zonas donde Daesh ha librado cruentos combates como Kobane o Deir Ezzor. En estos mensajes deja claro que "los insurgentes la trataban con el respeto que merece una hermana" (TRAC, 2014). Su presencia no obstante, podía estar relacionada con otro tipo de actividades como es el suministro de víveres. La detención de la viuda de un alto mando de Daesh conocida como Umm Sayyaf continuó reforzando esta hipótesis de que las mujeres estaban más involucradas en la militancia armada. Sayyaf aseguró que Daesh cuenta con todo un comando de mujeres en labores de inteligencia (YOUSSEF y HARRIS, 2015). 
Tras el recrudecimiento de la guerra a finales de 2016 el grupo cambia su concepto de estrategia ofensiva a defensiva y emplaza por primera vez y de manera abierta a las mujeres a la lucha. El llamamiento a las armas tiene su precedente en diciembre de 2016 en el noticiero semanal al-Naba, también del grupo y cuyo idioma de difusión es el árabe. En el recuerda que pese a que la yihad no es una obligación para las mujeres, las musulmanas deben saber que si el enemigo entra, la yihad es tan necesaria para ellas como para los hombres y debe repeler el ataque con cualquiera de los medios disponibles (WINTER y MARGOLIN, 2017: 24). Este mensaje se traslada a su público occidental en el número 11 de Rumiyah en el que la organización anima a las mujeres al final del ensayo Our journey to Allah a "levantarse con coraje y sacrifico en esta guerra, no por la falta de hombres sino por su amor a la yihad". El artículo, que sale a la luz en julio de 2017, utiliza a referentes clásicos como Umm Umara para justificar su participación en la lucha armada. Conforme iba avanzando la contienda, el grupo llegó a recrudecer aún más su mensaje señalando que "era necesario y obligatorio para las mujeres luchar en la yihad" (DEARDEN, 2017). Un hecho que supone el quebrantamiento de una de sus normas sociales básicas.

En junio de 2017 varios medios de comunicación occidentales publicaron que 38 mujeres se habían inmolado en Mosul. Un total de 20 lo hicieron entre el 2 de julio de 2017 y el 5 del mismo mes como último esfuerzo para tratar de frenar las tropas iraquíes (ENSOR, 2017). Estas operaciones, no obstante, no han sido reivindicadas por el grupo terrorista (WINTER y MARGOLIN, 2017: 23) y según un informe del Instituto Nacional de Estudios de Seguridad Israelí (INSS) tan solo 7 han podido ser verificadas (SCHWEITZER y MENDELBOIM, 2018). Una de estas misiones pudo registrarse gracias a una instantánea tomada momentos antes de que una mujer se inmolara acompañada de un niño pequeño. Esta hizo estallar una bomba que llevaba debajo del niqab justo cuando pasaba delante de los miembros de seguridad iraquíes (BLOOM y COTTEE, 2017). El acto supone una evolución con respecto a $\mathrm{AQI}$ ya que solamente Boko Haram ha llegado a utilizar a mujeres con sus hijos en una ofensiva. ELS denunció también el uso de mujeres suicidas en la provincia de Deir EzZor en 2019 (ABU AL-KHAIR, 2019).

Diversas fuentes apuntan a que una mujer de origen ruso combatió como francotiradora en la batalla de Mosul (OLTERMANN y HAWRAMY, 2017) y varias mujeres de diferentes nacionalidades fueron encontradas en un bunker con un gran arsenal de explosivos (SLAWSON, 2017). Asimismo, algunos corresponsales señalaron también que había mujeres luchando de manera activa en el campo de batalla de la ciudad Siria de Deir Ezzor 
(MCKERNAN, 2017). Estos datos supusieron un revulsivo para la comunidad académica, que se mostró escéptica por el origen de las fuentes y pidió cautela (LAHOUD, 2017). Sin embargo, el grupo confirmó este rumor con la difusión en febrero de 2018 de un vídeo a través de su aparatado de propaganda en el que podía verse a mujeres luchando junto a hombres en un campo de batalla (DEARDEN, 2018).

Se trata de la primera vez en la historia que un grupo yihadista emitía imágenes de mujeres participando activamente en una contienda y empuñando armas. El vídeo llegó a través de Al Hayat Media Center y mostraba a mujeres usando niqab, por lo que a diferencia de otros vídeos protagonizados por hombres no podía extraerse la identidad de estas. El documento hacía alusión a al-Zarqawi y señalaba que las mujeres estaban luchando para vengar la pérdida de honor sufrido por "sus hermanas musulmanas" debido a los abusos de la comunidad internacional y del régimen de Bashar al-Asad. Además, reconocía con esta participación "la entrada en una nueva era" (PEARSON, 2018). Las evidencias que respaldan esta nueva tendencia han quedado registradas en más de un documento visual. En marzo de 2019 la agencia Amaq News difundió un vídeo en el que se ve a mujeres luchando en al Baguz, uno de los últimos bastiones de Daesh (ENSOR y LUHN, 2019). Un insurgente ruso también inmortalizó esta lucha grabando a una mujer en primera línea de combate. La militante se dirige a la cámara señalando que "las balas de estos infieles son débiles". El hombre que capta la escena ensalza el valor de la mujer con la siguiente afirmación: "estas hermanas son más útiles que algunos hermanos". ${ }^{4}$

Esta incursión supone la entrada en una nueva era para la violencia política ejercida por una mujer en un grupo yihadista tal y como remarca el mismo Daesh en su aparato de propaganda. Se trata de un deseo cumplido por parte de las mujeres seguidoras de esta corriente yihadista $y$, más concretamente, de los postulados de Daesh. Estas han mostrado su predisposición y deseo de poder luchar y utilizar armas asegurando que su único freno residía en contar con el beneplácito de la organización. Así lo han manifestado en sus perfiles sociales varias jóvenes occidentales que llevaron a cabo la migración (HOYLE et. al., 2015). El grupo se ha hecho eco de estas aspiraciones a través del semanal Al-Naba (LAHOUD, 2017) y lo han registrado periodistas después de entrevistarse con mujeres desplazadas a los territorios controlados por el grupo (THOMPSON, 2016).

4 Perfil de Twitter @alg_hismendi, (2019, 21 de marzo), el vídeo puede verse en la red social Twitter el siguiente enlace: https://twitter.com/werej_1/status/1 108738701406949377 (última consulta: 24 de diciembre de 2019). 


\section{LAS FUERZAS KURDAS DE SIRIA}

Los kurdos están considerados como el mayor grupo étnico sin estado del mundo y su población está repartida entre Turquía, Irán, Irak o Siria, país en el que alcanza el 10\% de la población (The World Factbook, 2019). El movimiento nacional kurdo existe en el país desde hace al menos un siglo e históricamente ha estado más fragmentado que sus homólogos en las sociedades turcas e iraquíes (SZEKELY, 2019: 7). Las divisiones entre zonas urbanas y rurales durante el periodo otomano y francés en Siria impidieron el surgimiento de un movimiento político unificado. No es hasta el año 2003 cuando se forma el Partido de la Unión Democrática Siria (PYD, en sus siglas en kurdo), con claros vínculos al Partido de los Trabajadores del Kurdistán (PKK, en sus siglas en turco). Su brazo armado en la guerra se constituyó como las Unidades de Protección Popular (YPG) y las Unidades de Protección Femenina (YPJ, en sus siglas en kurdo).

EI PYD aboga por un modelo político regido por la igualdad de género. El feminismo se ha convertido en la bandera identificativa de la constrainsurgencia y son numerosos los medios de comunicación occidentales que se han hecho eco de esta inclusión en las filas del grupo. Sin embargo, este componente identitario en torno a la ideología de género está presente en el movimiento desde el comienzo gracias a sus raíces marxista-leninistas (DAVIS, 2017). El líder teórico del movimiento, Abdullah Öcalan, considera que la opresión y la injusticia social están relacionadas directamente con la jerarquía de género y apuesta por la liberación de las mujeres como medio para poder superarlas (SIMSEK y JONGERDEN, 2018: 13). De hecho, Öcalan propone una percepción nueva a través de 'jinoloji', un concepto que se construye a partir de la palabra jin (mujer en kurdo) y loji (del griego razón) y que se traduciría como la ciencia de la mujer.

Estas han jugado un rol importante en la política kurda a lo largo de la historia. Öcalan funda junto a su mujer, Kesire Yildirim, el PKK y cuenta desde sus orígenes con mujeres entre sus miembros. La presencia femenina está garantizada en diferentes roles dentro del campo de la logística, de la propaganda o la financiación e incluso en posiciones de liderazgo estratégico (DAVIS, 2017: 79). En los órganos mixtos del PKK y el PYD existe además una cuota de género y los puestos de liderazgo deben estar compuestos, al menos, por un $40 \%$ de mujeres (DE JONG, 2016). No obstante, hay autores que señalan que la sociedad kurda ha estado tradicionalmente dominada por una estructura patriarcal (TASTEKIN, 2014) en la que es bastante común para las mujeres, por ejemplo, contraer matrimonio a corta edad. Luchar se ha convertido para muchas de ellas en la manera de escapar de los roles tradicionales que se presupone para ellas (LAZARUS, 2019). 
El brazo armado kurdo se creó en el año 2012 con el objetivo prioritario de defender a su población de los ataques de Daesh y del régimen de Bashar al-Asad. En esos primeros meses se establecieron comandos mixtos para todos los que querían alistarse. Es tras la incorporación de mujeres combatientes y experimentadas del PKK en el año 2013 cuando finalmente se crean las Unidades de Protección Femenina (YPJ) (SZEKELY, 2019: 8). Según algunos autores, con la intención de romper con la jerarquía de género imperante en los grupos mixtos (DE JONG, 2016) y de evitar el acoso sexual que sufrieron las primeras milicias mixtas del PKK (CRAGIN y DALY, 2009: 67). La brigada no solamente está formada por kurdas sino que también cuenta con una presencia minoritaria de europeas, estadounidenses o árabes de las regiones liberadas de Daesh (LAWRENCE, 2019). Es difícil estimar el número aproximado de combatientes ya que no existen datos debidamente contrastados, aunque algunas fuentes han apuntado que son 10.000 las mujeres que sirven a la causa kurda (COGHLAN, 2016).

Durante el conflicto las mujeres han tenido un rol operativo también importante y hay varios ejemplos de ello. La contienda de Kobane fue liderada por la comandante Meysa Abdo, conocida por el nombre de guerra de $\mathrm{Na}$ arin Afrin (GORMAN, 2017: 32). No es la única figura femenina relevante del conflicto, la comandante Rojda Felat también lideró la campaña para expulsar a Daesh de Raqa. Felat tenía a su mando un contingente mixto de 15.000 combatientes kurdos y árabes. Además, también contaba con el respaldado de las fuerzas especiales de Estados Unidos (COGHLAN, 2016).

Las operaciones de suicidio han sido una de las tácticas empleadas de forma habitual durante las ofensivas. Así, fuentes kurdas señalan que de los primeros 20 ataques que llevó a cabo el grupo durante la batalla de Kobane, 10 eran mujeres. Las mismas fuentes confirman que durante el año 2013 se realizaron 700 atentados suicidas en nombre de las YPG, 200 de los cuales fueron protagonizados por mujeres. La primera en inmolarse fue la joven Selmo Guliselmo en el año 2012 en la ciudad de Alepo (TASTEKIN, 2014). Sin embargo, esta táctica no es una novedad para los kurdos, el Partido de los Trabajadores del Kurdistán creó en el año 1996 un ala militar compuesta por mujeres para llevar a cabo principalmente ataques suicidas.

La mayoría de estos primeros ataques fueron protagonizados de manera desproporcionada por mujeres, un 73\% del total (CRAGIN y DALY, 2009: 67). A este respecto, la investigadora Whaley Eager manifestó que estas provenían, principalmente, de familias con escasos recursos y solían ser reclutadas con 10 años. A esa edad comenzaban un entrenamiento alejadas de su familia con el fin último de dar la vida por la causa kurda (EAGER, 
2008). Estos abusos también han sido puestos en evidencia en el conflicto sirio. Así, en el año 2014 The Syrian Network for Human Rights, reveló el secuestro y el reclutamiento forzado de 69 mujeres, 34 menores de edad, por las milicias kurdas (SN4HR, 2015).

Las mujeres han demostrado a lo largo de la historia ser más efectivas perpetrando ataques suicidas que los hombres debido a que su uso ha sido inesperado por los soldados o los cuerpos de seguridad. Gracias a este factor sorpresa las mujeres cuentan con un mayor índice de letalidad que sus compañeros varones (O'ROURKE, 2009: 682). Además, su participación en actos violentos también adquiere mayor cobertura en los medios de comunicación, circunstancia que es aprovechada por los grupos para lograr notoriedad (SPECKHARD, 2008: 42). El rol de mujeres combatientes dentro de las fuerzas kurdas ha sido el principal mensaje propagandístico difundido por la contrainsurgencia a los medios de comunicación occidentales. La caracterización que se ha hecho de ellas ha sido de valientes e independientes, al contrario que la imagen que se ha trasladado de las mujeres que se han unido a Daesh. La cobertura que se ha hecho de estas últimas ha potenciado su imagen de víctimas, difundiendo reportajes que en gran medida versaban sobre su papel como "las novias de la yihad" (SJOBERG, 2018: 303).

No ha sido el único mensaje que han transmitido. Existen también vídeos, documentales y reportajes exponiendo que los miembros del grupo terrorista Daesh tienen la creencia de que no podrán acceder al Paraíso si les mata una mujer. ${ }^{5}$ Se han recogido varios testimonios apuntando que estos huyen despavoridos si son conscientes de que se trata de una mujer la que empuña un arma. "Monitoreamos sus llamadas de radio. Cuando escuchan la voz de una mujer se ponen histéricos" (TASTEKIN, 2014). El destacamento de mujeres kurdas iraníes también es consciente de esta ventaja operativa e incluso han llegado a entonar canciones por los altavoces antes de entrar en batalla con el objetivo de desestabilizarlos (DEHGHANPISHEH y GEORGY, 2016).

\section{Otras brigadas femeninas en la guerra siria}

La presencia femenina en el campo de batalla no se ha limitado en el conflicto sirio a Daesh y a las fuerzas kurdas sino que hay al menos otros dos actores relevantes que cuentan con mujeres en sus filas. Estos han experimentado menor trascendencia mediática en Occidente pero también son

5 Uno de estos documentales puede verse en https://www.youtube.com/watch? $v=y b c s R b h n p n c$ 
relevantes a la hora de analizar el papel que está teniendo la mujer en la contienda y cuál es el propósito de esta repentina apuesta por la inclusión. A continuación, se analizan las brigadas femeninas del todavía presidente de la República, así como las del Ejército Libre Sirio.

\section{Las leonas de al Asad para la Defensa Nacional}

Las mujeres sirias han estado marginadas de la esfera política y del gobierno del país. La primera vez que una mujer fue electa para el Parlamento fue en el año 1973. En la actualidad, las mujeres ocupan 31 de los 250 escaños de dicha institución y solo el $5 \%$ ha alcanzado un puesto en algún ministerio (CHARLES y DENMAN, 2012: 202). No reflejan datos mejores la representación femenina dentro del poder judicial. Hasta 1975 las mujeres tenían prohibido ejercer la abogacía y en el año 2010 solamente el $13 \%$ de los jueces y los fiscales del país eran mujeres (UNICEF, 2011). Asimismo, la discriminación legislativa contra las mujeres en el país aún sigue evidente en derechos relacionados con la libre circulación por el territorio nacional, el reparto equitativo de la herencia o la poligamia (ALSABA y KAPILASHRAMI, 2016: 9). Las Fuerzas Armadas sirias cuentan con cientos de mujeres en el Ejército pero la mayoría ocupan puestos administrativos que no están muy bien remunerados (ATASSI, 2012).

Tras el estallido de la guerra Bashar al-Asad tampoco ha demostrado respeto por los derechos de las mujeres sirias. Así, diversos organismos se han encargado de denunciar las agresiones sexuales que han padecido cientos de mujeres en el conflicto por parte del régimen, que incluso emplea la violación como medio de tortura en las cárceles, en redadas dentro sus propios hogares o en puestos de control (HRW, 2012). Un informe del Consejo de Derechos Humanos de las Naciones Unidas del año 2018 recoge decenas de testimonios de mujeres que han sufrido este tipo de violencia. Una mujer denuncia en este mismo documento que un grupo de soldados de las fuerzas gubernamentales entraron en su casa en Homs y violaron a su hija. Tras matarla a ella y a su marido, la madre también acabó siendo violada por dos soldados (HRC, 2018: 7).

Dentro de este contexto, la Guardia Republicana Siria crea en el año 2013 el primer batallón femenino conocido como Las Leonas para la Defensa Nacional (SZERLY, 2019). Se trata de un cuerpo de élite cuya principal función es proteger los puestos de control fronterizos. En el año 2013 el 5\% de los soldados que ocupaban los puestos de control eran mujeres (SOHLMAN, 2013) y estas en raras ocasiones han sido vistas en primera línea de fuego (VOA News, 2013, 5 de junio). La formación está compuesta por unos 800 soldados pertenecientes, en su mayoría, a la minoría alauí. No es la 
única facción, en el año 2017 el gobierno crea un nuevo batallón llamado Jansawat Suriya. Está formado por unas 150 mujeres de la ciudad de Qamishli, en el norte del país (MCKERNAN, 2017).

Algunos autores señalan que la repentina incorporación responde más a una estrategia del presidente de la República que a una verdadera política de inclusión, sobre todo debido al contexto expuesto en Siria (SZEKELY, 2019). Al-Asad, con este viraje, está utilizando a las mujeres para promover una imagen de modernidad con el objetivo de diferenciarse de uno de sus máximos oponentes en el campo: Daesh (LEDUC, 2015). Asimismo, en la esfera mediática también necesita hacerle frente a la contrainsurgencia kurda. Para lograrlo varios medios afines al régimen han publicitado la labor de estas mujeres y en Youtube se pueden encontrar una gran variedad de vídeos que muestran entrevistas y grabaciones de estas entrenando, montando camiones y utilizando armas, generalmente con música (SCOTT, 2014).

Asimismo, otra de las razones que apuntan a esta nueva inclusión de las mujeres dentro del Ejército sirio se debería a la escasez de hombres dentro del cuerpo. Entre las deserciones, que comenzaron al poco de iniciarse las hostilidades en el año 2011 y las bajas producidas durante la guerra, que ascendían a unas 44.000 en el año 2014, el presidente ha visto mermado el número de sus fuerzas de 325.000 a 150.000 (KOZAK, 2014). Con estos datos el régimen estableció una campaña de reclutamiento desesperada, deteniendo incluso a jóvenes universitarios en Damasco o Dera y promulgando varios decretos para restringir la capacidad de los hombres en edad militar de abandonar el país (KOZAK, 2014).

\section{Ejército Libre Sirio: Nuestra madre Aicha}

Un grupo de oficiales desertores del Ejército sirio creaba el 29 de julio de 2011 el Ejército Libre Sirio (ELS). El coronel Riad al-Asad se situaba a la cabeza de la formación y declaraba que la misión de la fuerza armada era combatir al régimen de Bashar al-Asad y proteger a la ciudadanía de las masacres de las que estaba siendo objeto. Asimismo, el coronel también hacía un llamamiento animando a miembros del Ejército a que desertaran y se unieran a su causa (LAYLA, 2013). Zubaida al-Meeki fue la primera mujer con rango de oficial que desertaba de las filas de las fuerzas gubernamentales y se insertaba en el ELS en el año 2012. Al-Meeki, perteneciente a la minoría alauí, declaró públicamente que le era imposible permanecer en el Ejército sirio después de los crímenes que estaba perpetrando el régimen (ATASSI, 2012). Se unió a la oposición en un pueblo al sur de Damasco después de que el ELS tomara el control de la mayor parte de esta región (ATASSI, 2012). 
Al-Meeki nunca ha participado en un combate y su principal función en las filas del ELS consiste en entrenar a los nuevos combatientes voluntarios que se unían sin ningún tipo de bagaje castrense. La oficial preparó, por ejemplo, a los miembros de la brigada Yund Ala (Soldados de Alá) para entrar en batalla pese a que en Siria no sea frecuente que las mujeres entrenen a los hombres. Tan solo un año más tarde de su deserción comenzaron a aparecer varias brigadas femeninas vinculadas al ELS. Una de las más importantes es Nuestra Madre Aicha, que debe su nombre a la segunda mujer del profeta Mahoma y que lideró la conocida como batalla del Camello (656).

La brigada está constituida, principalmente, por mujeres universitarias del país y es una unidad que funciona de manera independiente en el aspecto formal. Entre sus funciones destaca proporcionar ayuda a la población civil, también están a cargo de dos hospitales de campaña para los heridos y tienen presencia en una estación de policía para mujeres detenidas (Reuters, 2015). En una sociedad patriarcal, donde los hombres y las mujeres suelen contar con espacios separados para evitar interacciones, resulta indispensable contar con presencia femenina para conseguir llegar a toda la población sin quebrantar las costumbres culturales. No es la única brigada femenina en la oposición, aunque el resto cuenta con un número menor de militantes y son más explícitas con su ideario islamista (HEFFEZ, 2013). Por ejemplo, la brigada femenina Sumayya bint Jayyat, ${ }^{6}$ aliada con la ELS, publicó en su perfil de Facebook una imagen de una mujer armada con banderas sirias en la que podía leerse su oposición a "los enemigos del Islam", catalogados como judíos, comunistas, rusos e infieles. ${ }^{7}$

También se dieron a conocer durante el conflicto la brigada suní Ikhlas, operativa en Alepo. Pese a que existen vídeos en los que se las puede ver ejerciendo labores de combate, lo cierto es que su función principal es llevar a cabo registros a otras mujeres en puestos fronterizos. La brigada Daughters of al-Walid en Homs, anunció en el momento de su fundación a través de YouTube que su misión era "cuidar a los heridos y ayudar a los refugiados". Miembros de las dos brigadas coinciden en que la brutalidad

6 La carga simbólica del nombre elegido para la brigada da buena cuenta de su base doctrinal ya que se trata de la primera mujer que se convirtió en mártir en tiempos del Profeta.

7 Perfil de Facebook @ktybtSmyhBntAlkhyat, (3013, 10 de marzo), el enlace para la página puede encontrarse aquí: https://www.facebook.com/KtybtSmyhBntAlkhyat/photos /a.594228527273470/631933690169620/?type=3\&theater (última consulta 24 de diciembre de 2019). 
del régimen y las agresiones sexuales que han sufrido las mujeres les han obligado a desafiar las normas tradicionales, apoyar la lucha armada así como aprender a defenderse (HEFFEZ, 2013).

Sin embargo, un ex oficial del Ejército sirio, que se unió a los rebeldes, señala en una entrevista que es escéptico sobre el valor que las mujeres tienen en los puestos de primera línea de combate y considera que su papel es, en gran medida, simbólico. El hombre pregunta de manera retórica al periodista que si se imaginaba a las mujeres peleando (SOHLMAN, 2013). Un activista de Homs también señalaba que el papel de las mujeres es puramente ornamental. "Los vídeos de brigadas femeninas a veces tienen la intención de avergonzar a los hombres para que se movilicen y participen en la lucha" (ATASSI, 2012). Este es el caso de un vídeo producido por facciones del ELS en el que puede verse a una mujer con un arma pronunciando un discurso en el que afea la conducta de los hombres que no están participando en las hostilidades. ${ }^{8}$

\section{CONCLUSIONES}

Los cuatro principales grupos que han sido objeto de análisis tienen diferentes enfoques en cuanto a la política de género, pero lo cierto es que su apuesta por la incursión femenina parece responder más a razones estratégicas o prácticas que a una verdadera búsqueda de igualdad entre hombres y mujeres. Así, pese a que Daesh se ha convertido en la primera organización yihadista que permite a sus mujeres entrar en batalla, esta circunstancia solamente se ha producido cuando el fin del califato estaba cerca y necesitaban recursos para poder defenderse.

Las mujeres kurdas se han convertido en un símbolo feminista en la esfera occidental gracias a la cobertura mediática que ha tenido su rol como combatientes y a la propaganda vertida por la contrainsurgencia kurda. Esta exposición mediática potenciando el lado femenino de las hostilidades no tiene precedentes en la organización y ha logrado construirle al grupo una narrativa para diferenciarse de Daesh, uno de sus grandes enemigos en el combate así como contar con una estrategia para desestabilizar su amenaza en el campo de batalla.

Por su parte, el gobierno de Bashar al-Asad no podía quedarse al margen de lo que parece una competición por trasladar a la audiencia una imagen

8 Sham qamshlo Sham, (2012, 20 de octubre), el vídeo se encuentra en https://www.youtube. com/watch?v=z1U2D4Ufdq8 (última consulta 24 de diciembre de 2019). 
de inclusión en la esfera internacional. Las políticas del régimen en cuanto a las mujeres, la obvia discriminación institucional y las agresiones que han sufrido durante la contienda son un claro indicador de que las razones para incluirlas en su Ejército responden más a una campaña de marketing que a una nueva política de igualdad. De hecho, si el presidente de la República considerara a estas capacitadas para el combate hubiera extrapolado los decretos promulgados para el servicio militar también a las mujeres.

Asimismo, hay otra razón que explica este florecimiento de las brigadas femeninas. Tal y como ha quedado patente a lo largo del artículo, la sociedad siria se rige por unas costumbres claramente conservadoras, aún más potenciadas en el caso de los grupos islamistas. Estos necesitan emplear a las mujeres para asegurarse que las normas patriarcales por las que se rigen no corren el riesgo de quebrantarse. Por eso, tal y como se ha descrito, el principal papel de las mujeres es abastecer a la población o hacer registros en los puestos de control. Este papel que asumen las mujeres en las filas de la oposición no tiene por qué estar reñido con su deseo de participar en la contienda en la medida que sus convicciones se lo permitan.

Por último, es pertinente señalar que queda mucho por conocer acerca de las motivaciones que han llevado a estas mujeres a participar en cada uno de los grupos que se han analizado, así como el papel que han tenido dentro de los mismos. La posguerra traerá consigo las verdaderas consecuencias de esta inclusión y se podrá observar si su rol estuvo motivado por las circunstancias y las dinámicas de la guerra o si era el comienzo de una ruptura con las costumbres que imperan en la sociedad y puedan liderar la construcción de una Siria en paz.

\section{Bibliografía}

ABINGTON, Timothy (2019), "Armies of women: The Syria crisis and the new war thesis", E-international Relations Students [https://www.e-ir. info/2019/03/27/armies-of-women-the-syria-crisis-and-the-new-warthesis/]

AL-MUHAJIRAH, Umm Summayyah (2015), "A jihad without fighting", From the battle of Al-Ahzab to the war of coalitions, Dabiq, al Hayat Media Center, $n^{\circ} 11$, pp.40-45.

AL-KHAIR, Waleed (2019, 2 de febrero), "Isis deploys female bombers in last Syria bastion", Diyaruna [https://diyaruna.com/en_GB/articles/ cnmi_di/features/2019/02/15/feature-02].

AL- AZMI, Hamad; ZAKARIYA, Ahmad (2014, 29 de octubre), "Syria's FSA officer says Kuwaiti women fighting alongside Islamic State", Al Watan (recuperado con BBC Monitoring). 
ALSABA, Khuloud; KAPILASHRAMI, Anuj (2016), "Understanding women's experience of violence and the political economy of gender in conflict: the case of Syria", Reproductive Health Matters, vol. 24:47, pp.5-17

ÁlVAREZ-OSSORIO, Ignacio (2016), Siria, revolución, sectarismo y yihad, Los Libros de la Catarata, Madrid.

ATASSI, Basma (2012, 23 de octubre), "Defected women general trains Sirya's rebels", Al Jazeera [https://www.aljazeera.com/indepth/features/2012/10/20121022105057794364.html]

AVILÉS, Juan, (2017), Historia del terrorismo yihadista: de Al Qaeda a Daesh, Síntesis, Madrid.

BLOOM, Mia (2011), Bombshell: Women and terrorism, University of Pennsylvania Press, Filadelfia.

BLOOM, Mia y COTTEE, Simon (2017, 8 de septiembre), "The myth of the ISIS Female Suicide Bomber", The Atlantic [https://www.theatlantic.com/ international/archive/2017/09/isis-female-suicide-bomber/539172/].

CHARLES, Lorraine y DENMAN, Kate (2012), "Every knot has someone to undo it. Using the capabilities approach as a lens to view the status of women leading up to the Arab Spring in Syria", Journal of International Women's Studies, vol. 13:5.

CHINKIN, Christine y KALDOR, Mary (2013), "Gender and new wars", Journal of International Affairs, vol. 67:1, pp.167-187

COGHLAN, Tom (2016), "Revolutionary kurdish feminist leads assault on Raqqa", The Times [https://www.thetimes.co.uk/article/revolutionary-kurdish-feminist-leads-assault-on-raqqa-29kdsrgpc].

CRAGIN, Kim y DALY, Sara (2009), Women as terrorists, Mothers, recruiters, and martyrs, Preager, California.

CUNNINGHAM, Karla J. (2003), "Cross-Regional Trends in Female Terrorism", Studies in Conflict \& Terrorism, vol, 26:3, pp.171-195.

DAVIS, Jessica (2017), Women in modern terrorism: from liberation wars to global jihad and the Islamic State, Rowman \& Littlefiel, Maryland.

DAVIS, Jessica (2018), "Women and the Isil phenomenon: from recruiters to suicide bombers and everything between" [https://www.researchgate.net/ publication/322505279_Women_and_the_ISIL_phenomenon_from_recruiters_to_suicide_bombers_and_everything_in_between].

DE CATALDO, Luisella y TIZIANA, Valentini (1992), Il filo di Arianna. Donne, eversione armata e pentitismo, CEDAM, Padua.

DE JONG, Alex (2016), "¿A commune in Rojava?", New Politics, vol. XV:4 [https://newpol.org/issue_post/commune-rojava/]. 
DEARDEN, Lizzie (2017, 6 de octubre), "Isis calls on women to figth and launch terror attacks for the first time", Independent [https://www.independent. co.uk/news/world/middle-east/isis-war-syria-iraq-women-call-to-arms-islamic-state-terror-attacks-propaganda-change-ban-frontline-a7986986.html].

DEARDEN, Lizzie (2018, 8 de febrero), "Isis propaganda video shows women fighting for the first time amid desperation to bolster ranks", Independent [https://www.independent.co.uk/news/world/middle-east/isis-video-women-jihadis-female-fighters-recruitment-syria-iraq-islamic-state-propaganda-a820062 1.html].

DEHGHANPISHEH, Babak y GEORGY, Michael (2016, 3 de noviembre), "Kurdish women fighters battle Islamic State with machineguns and songs", Reuters [https://www.reuters.com/article/us-mideast-crisis-mosul-womenfighters/kurdish-women-fighters-battle-islamic-state-with-machineguns-and-songs-idUSKBN12Y2DC].

DJAMILA, Danièle y ABU-HAIDAR, Farida (1999), "Women and politics in Argelia from the war of independence to our day", Research in African Literatures, vol. 30:3, pp. 62-77, Indiana University Press.

DOOLEY, Stacey (2018, 6 de marzo), "Meet the former sex slaves fighting IS on the front line", BBC [https://www.bbc.co.uk/bbcthree/article/647a4bda-f52b-4642-a39b-bde3e6ec8f14].

EAGER, Paige (2008), From freedom fighters to terrorists: women and political violence, Routledge, Londres.

ENSOR, Josie (2017, 10 de julio), "Chilling picture shows female Isil fighter holding child moments before detonating suicide vest", The Telegraph [https://www.telegraph.co.uk/news/2017/07/08/chilling-picture-shows-female-isil-fighter-holding-child-moments/].

ENSOR, Josie y LUHN, Alec (2019, 22 de marzo), "Women take to the front lines as desperate Isil fights to the end", The Telegraph [https://www. telegraph.co.uk/news/2019/03/22/isil-relaxes-rules-let-women-takearms-jihadists-final-stand/].

FREEDOM HOUSE (2010, marzo), "Women's Rights in the Middle East and North Africa 2010 - Syria" [https://www.refworld.org/docid/4b9901 ldc.html].

GHAZZAWI, Razan (2014, 8 de abril), "Seeing the women in revolutionary Syria", Open Democracy [https://www.opendemocracy.net/en/north-africa-west-asia/seeing-women-in-revolutionary-syria/]

GORMAN, Shawn. E (2017), Are female counterinsurgency units effective? A case study of the female kurdish militias of Iraq and Syria, Georgetown University, Tesis de Licenciatura. 
HAUSMANN, Ricardo; TYSON Laura D. y ZAHIDI, Saadia (2011), "The Global Gender Gap Report", World Economic Forum [http://reports.weforum.org/global-gender-gap-2011/].

HEFFEZ, Adam (2013, 29 de julio), "When women joined the jihad in Syria", Haaretz [https://www.haaretz.com/opinion/.premium-adam-heffez-women-warriors-in-syria-1.53 14117 ].

HOYLE, Carolyn; BRADFORD, Alexandra y FRENETT, Ross (2015) "Becoming Mulan? Female Western Migrants to ISIS", Institute for strategic Dialogue [https://www.isdglobal.org/wpcontent/uploads/2016/02/ ISDJ2969_Becoming_Mulan_01.15_WEB.pdf ].

HUFF, Zach, (2017, julio), "Exclusive: Christian Women Up Against ISIS", Clarion Project [https://clarionproject.org/christian-women-against-isis/].

HUMAN RIGHTS WATCH (2012, junio), Syria: sexual assault in detention [https://www.hrw.org/news/2012/06/15/syria-sexual-assault-detention].

HUMAN RIGHTS WATCH [HRW], World report 2019: events of 2018 [https://www.hrw.org/sites/default/files/world_report_download/hrw_ world_report_2019.pdf].

HUMAN RIGHTS COUNCIL (HRC) (2018, marzo), "I lost my dignity": sexualy and gender-based violence in the Syrian Arab Republic, A/HRC/37/ CRP.3

JAWAD AL-TAMIMI, Aymenn (2016, 17 de octubre), "The Archivist: Stories of the Mujahideen: Women of the Islamic State", Jihadology [http://www. aymennjawad.org/19291/the-archivist-stories-of-the-mujahideen-women].

JEANNE, Billie (2017), "Revolutionary damascene roses: women and media in the Syrian conflict", en PROFANTER, Annemarie y MAESTRI, Elena (eds.), Arab women and the media in changing landscapes: realities and changes, Palgrave Macmillan, Londres, pp. 229-244.

KOZAK, Christopher (2014, diciembre), "The Assad Regime Under Stress: Conscription and Protest among Alawite and Minority Populations in Syria", Institute for the Study of War [http://iswresearch.blogspot.com/2014/12/ the-assad-regime-under-stress.html].

LAHOUD, Nelly (2017), "Can women be soldiers of the Islamic state?", Survival. Global Politics and Strategy, vol. 59:1, pp. 61-78.

LAYLA, Karel, (2013), "Mothers at home and activists on the street?". The role of women in the Syrian revolution of 2011-2012, MIR, vol 2:3, pp. 16. LAWRANCE, Joey $(2019,26$ de junio), "Faces of war: Kurdistan's armed struggle against Islamic State", The Guardian [https://www.theguardian.com/world/2019/jun/26/faces-of-war-kurdistan-armed-struggle-against-islamic-state]. 
LAZARUS, Sarah (2019, 27 de enero), "Women. Life. Freedom. Female fighters of Kurdistan", CNN [https://edition.cnn.com/2019/01/27/homepage2/kurdish-female-fighters/index.html].

LUCAS, Scott (2014, 9 de abril), "Syria video: women, join the militia!", EA World Video [https://eaworldview.com/2014/04/syria-video-women-join-militia/].

MCDONALD, Eileen (1991), Shoot the Women First, Random House, Nueva York.

MCKERNAN, Bethan (2017, 2 de febrero), "Syrian army creates new women's unit to fight Isis", Independent [https://www.independent.co.uk/ news/world/middle-east/syrian-army-creates-womens-unit-fighting-isis-islamic-state-bashar-al-assad-regime-terror-group-a7558896.html] .

NASSER, Rabie y MEHCHY, Zaki (2012), "Determinants of Labour Force Participation in Syria (2001-2010)", Economic Research Forum, Working Paper $n^{\circ} 698$ [http://erf.org.eg/publications/determinants-labor-force-participation-syria-2001-2010/].

O'ROURKE, Lindsey (2009), "What's Especial about Female Suicide Terrorism?", Security Studies, vol. 18:4, pp.681-718

OLTERMANN, Philip y HAWRAMY, Fazel (2017, 19 de julio), "Suspected Isis fighter seized in Mosul may be missing German girl, 16", The Guardia[https://www.theguardian.com/world/2017/jul/19/isis-mosul-missing-german-girl-linda-wenzel].

REUTERS, (2015, 4 de enero), "Politics civil unrest conflict" [https://pictures.reuters.com/archive/SYRIA-CRISIS-GM1EB 1507BX01.html].

RUMIYAH (2017, julio) "Our journey to Allah", The ruling on ghanimah, fay and ihtitab, Rumiyah, al Hayat Media Center, n¹1, p.12-15

SCHWEITZER, Yoram y MENDELBOIM, Aviad (2018), "Report on suicide attacks in 2017: Fewer attacks, more women bombers", Instituto of National Securities Studies (INSS), n 1008 [http://www.inss.org.il/publication/ report-suicide-attacks-2017-fewer-attacks-women/].

SIMSEK, Bahar y JONGERDEN, Joost (2018), "Gender revolution in Rojava: The voices beyond tabloid geopolitics", Geopolitics.

SJOBER, Laura. (2018), "Jihadi brides and female vounteers: reading the Islamic State's war to see gender and agency in conflict dynamics", Conflict and management and peace science, vol. 35:3, pp. 296-311.

SLAWSON, Nicola (2017, 22 de julio), "German girls arrested in Mosul is missing Linda Wenzel, say authorities", The Guardian [https://www. theguardian.com/world/2017/jul/22/german-girl-arrested-mosul-isis-missing-linda-wenzel-16]. 
SOHLMAN, Eva (2013, 11 de abril), "Sisters in arms join the fighting in Syria", The New York Times [https://www.nytimes.com/2013/04/11/ world/middleeast/sisters-in-arms-join-the-fighting-in-syria.html].

SPECKHARD, Anne (2008), "The emergence of female suicide terrorists", Studies in Conflict and Terrorism, vol. 31:11, pp. 995-1023.

SYRIAN NETWORK FOR HUMAN RIGHTS (SN4HR) (2015), Syrian women in the eye of the storm [http://sn4hr.org/wp-content/pdf/english/Syrian_women_in_the_center_of_the_hurricane_en.pdf].

SZELKY, Ora (2019), "Fighting about women: ideologies of gender in the Syrian civil war", Journal of Global Security Studies, Oxford University Press, pp. 1-19

TASTEKIN, Fehim (2014, 8 de octubre), "Kobani is becoming Turkey's war", Al Monitor [https://www.al-monitor.com/pulse/originals/2014/10/ turkey-syria-kurds-isis-kobani-war.html].

TERRORISM RESEARCH \& ANALYSIS CONSORTIUM (2014), From Canada to the Islamic State: a Canadian woman on the frontlines with Isis [https://www.trackingterrorism.org/article/canada-islamic-state-canadian-woman-frontlines-isis ].

THOMSON, David, (2016), Les Revenants, Le Seuil, París.

UNICEF (2016), "A profile of child marriage in the Middle East and North Africa" [https://www.unicef.org/mena/media/2641/file/MENA-ChildMarriageReport.pdf.pdf].

UNICEF (2011), "SYRIA, MENA Gender Equality Profile. Status of girls and Women in the Middle East and North Africa" [https://www.unicef.org/ gender/files/Syria-Gender-Eqaulity-Profile-2011.pdf].

VICTOR, Barbara (2004), Army of Roses. Inside the World of Palestinian Women Suicide Bombers, Constable \& Robinson, Londres.

VINOGRADOVA, Lyuba (2017), Ángeles vengadores: las francotiradoras soviéticas en la Segunda Guerra Mundial, Pasado \& Presente. Barcelona. VOA NEWS (2013, 5 de junio), "Women a Small, Symbolic Part of Syrian Fighting Force" [https://www.voanews.com/world-news/middle-east-dontuse/women-small-symbolic-part-syrian-fighting-force].

WINTER, Charlie y MARGOLIN, Devorah (2017, 3 de agosto), "The mujahidat dilemma: Female combatants and the Islamic State", CTC Sentinel, pp. 23-33.

YEGINSU, Ceylan (2018, 26 de julio), "Mary Ellis, who flew british spitfires in World War II, diez at 101", The New York Times [https://www. nytimes.com/2018/07/26/obituaries/uk-mary-ellis-dead.html]. 
YOUSSEF, Nancy y HARRIS, Shanae (2015, 7 de mayo), "The women who secretly keep Isis running", The Daily Best [https://www.thedailybeast. com/the-women-who-secretly-keep-isis-running].

ZAMAN, Amberi, (2017, 6 de noviembre), "Syria's Arab, Kurdish women join forces to fight for future", Al Monitor [https://www.al-monitor.com/ pulse/originals/2017/11/syria-raqqa-fight-kurds-women-sdf-islamic-state. html\#ixzz5t67cZRDO]. 
Estudis 



\title{
LAS ÚLTIMAS GIRAS DE LOS BAILES RUSOS DE DIAGHILEV EN ESPAÑA: BARCELONA (1924- 1927)*
}

\section{THE LAST TOURS OF DIAGHILEV'S RUSSIAN DANCES IN SPAIN: BARCELONA (1924-1927)}

\author{
Pedro Castillo Palomares \\ Doctor en Historia
}

\section{RESUMEN}

El presente trabajo analiza la cobertura mediática de la prensa publicada en Barcelona en los años que van de 1924 a 1927 del espectáculos de los bailes rusos del empresario Sergue Diaghilev y su reaparición en el Gran Teatre del Liceu desde su última actuación en el año 1918. Se describen las sesiones y la composición de los programas de los días de actuación junto con las impresiones de la crítica teatral sobre las representaciones de los ballets russes.

Palabras clave: Sergue Diaghilev, ballets russes, Liceu, Artes Escénicas, Historia de la Cultura.

\section{ABSTRACT}

The present work analyses the media coverage in the press published in Barcelona during the period from 1924 to 1927 regarding the Russian dance shows organised by the businessman Sergue Diaghilev and its reappearance in the Gran Teatre del Liceu since the last performance in 1918. The sessions are described, as is the composition of the programmes of the performances and the impressions of the theatrical reviews of the ballets russes productions.

Keywords: Sergue Diaghilev, ballets russes, Liceu, Performing Arts, History of Culture.

* El presente artículo es una ampliación los puntos 3 y 4 del capítulo 4 de la Tesis doctoral defendida en el año 2017, Crónicas españolas de los bailes rusos de Diaghilev (1916-1927), y que inexorablemente mantiene la estructura del calendario de los días de sesiones correspondientes a las programaciones de la compañía de Diaghilev en el Gran Teatro del Liceo los años 1924, 1925 y 1927. Desde el respeto a las fuentes y a la ética científica se ha visto la necesidad de presentar esta propuesta complementaria con material inédito no publicado para ampliar y entender mejor la acogida de compañía rusa por parte de la crítica de espectáculos de la prensa de Barcelona. 


\section{RESUM \\ LES DARRERES GIRES DELS BALLS RUSSOS DE DIAGHILEV A ESPAÑA: BARCELONA (1924-1927)}

El present treball analitza la cobertura mediàtica de la premsa publicada a Barcelona en els anys que van de 1924 a 1927 de l'espectacle dels balls russos de l' empresari Sergue Diaghilev i la seva reaparició al Gran Teatre del Liceu des de la seva última actuació en l'any 1918. Es descriven les sessions i la composició dels programes dels dies d'actuació juntament amb les impressions de la crítica teatral sobre les representacions dels ballets russes.

Paraules clau: Sergue Diaghilev, ballets russes, Liceu, Arts Escèniques, Història de la Cultura. 
La compañía de ballets russes del empresario Serge Diaghilev a partir de su presentación en Paris en mayo de 1908 llevó a cabo diferentes giras artísticas por Europa, Estados Unidos y Suramérica durante la segunda y tercera década del siglo XX hasta la muerte de su creador y director el 19 de agosto de 1929. Durante este periodo de tiempo visitaron España en diferen- tes ocasiones entre los años 1916 y 1927.

Las primeras giras españolas fijadas en varios momentos temporales de mayo 1916 a junio 1918 vienen determinadas por la Primera Guerra Mundial, la neutralidad de España en el conflicto y las consecuencias económicas y artísticas que la contienda tiene para el devenir organizativo de la compañía rusa. El proyecto empresarial y artístico de los ballets russes llegó casi a su disolución en el verano de 1918. ' Después de esta gira se descolgaron varios componentes del cuerpo de baile del ya casi insolvente proyecto diaghileviano al finalizar el verano de 1918.como Valentina Kachouba, ${ }^{2}$ Alexander Gavrilow, ${ }^{3}$ Nicola Zverev o Vera Nemtchinova. ${ }^{4}$

1 Diaghilev tras unos años de reajuste organizativo en Londres tras el fin de la Primera Guerra Mundial en los que recuperó la iniciativa empresarial de los ballets russes, las pérdidas materiales y personales sufridas durante 1918, su compañía de bailes rusos afrontó los retos de un renovado mercado escénico surgido a comienzos del periodo de entreguerras en Europa. Al acabar el conflicto bélico la historiadora Lynn Garafola observó la llegada de la paz a Europa trajo consigo una expansión de la danza por el continente con el nacimiento de nuevas compañías de ballets en diferentes países que imitaban al estética de los bailes rusos y que empezaron a disputarle el protagonismo a Diaghilev dentro del mercado del espectáculo. En los años previos del armisticio solo Valentina Palvlova había experimentado con producciones entre la ópera y el music-hall, a partir de la década de los veinte surgieron nuevas propuestas escénicas con un reflejo de la concepción diaghileviana del ballet. GARAFOLA, Lynn (1998), pp. 211 y 217.

2 Valentina Kashouba llegó a actuar con una compañía de bailes rusos en el Teatro Lara de Madrid en noviembre de 1921, El Imparcial, 1 de noviembre de 1921, p. 6.

3 Dirigía una troupe de bailes rusos que interpretaban obras del repertorio de Diaghilev como las danzas de "El príncipe Igor". Actuaron a principios de mayo de 1921 en el teatro de La Zarzuela de Madrid, ver La Época, 4 de mayo de 1921, sección espectáculos.

4 Aunque en el caso de estos dos últimos bailarines se reincorporaron más tarde después de actuar con otras compañías por España. 
Las siguientes tournées enmarcadas ya dentro del periodo político y social de entreguerras europeo y de la crisis del sistema de La Restauración en España, se fijan en los años 1921 y 1922 en Madrid y San Sebastián, ${ }^{5}$ respectivamente. $Y$ en último lugar, se sitúan las giras que ponen fin al periplo español de los ballet russes durante los años 1924, 1925 y 1927 en Barcelona, dentro del contexto político de la dictadura de Miguel Primo de Rivera. Sergue Diaghilev y su compañía de bailes rusos desde el año 1918, tras años de ausencias en el escenario del Gran Teatro del Liceo, volvían a la capital catalana cuya oferta del espectáculo se había diversificado desde su última visita.

\section{Año 1924. Estreno de el sombre- RO DE TRES PICOS EN BARCELONA}

Habían pasado casi seis años desde la última actuación de los ballets russes de Diaghilev en Barcelona y la dirección del Liceo a cargo de la empresa de Juan Mestres programó la vuelta de la compañía de danza para el sábado 19 de abril. ${ }^{6}$ Los primeros anuncios de la reaparición de la compañía comenzaron en el mes de marzo con una campaña publicitaria en la prensa de Barcelona coincidiendo con las actuaciones en el teatro situado en Las Ramblas del compositor ruso Igor Stravinsky. ${ }^{7}$ Por ejemplo, el diario La Vanguardia no sólo publicitó a la compañía en la sección de espectáculos, sino también en el apartado de Notas Locales: "En breve los auténticos Bailes Rusos de Serge Diagilew". La principal novedad de las sesiones era la presentación de "El sombrero de tres pi$\cos ^{\prime \prime}$ en Barcelona. ${ }^{8}$ Aunque por su parte el Diario de Barcelona destacara los "cuatro hermosos ballets" programados para la noche del 19 de abril de 1924 y el "aspecto bri-

5 Antes del regreso de los bailes rusos a la capital catalana, en las últimas giras españolas que comprenden los años de 1921 y 1922 Diaghilev había estrenado "El sombrero de tres picos" en Madrid, y los bailes rusos fueron la gran atracción de los actos conmemorativos del IV centenario de la vuelta al mundo de Juan Sebastian Elcano en el Gran Kuursal de San Sebastian. En su regreso a Barcelona en la década de los veinte del siglo pasado, los ballets russes de Diaghilev habían dejado de ser una novedad en España.

6 Programa de mano de la presentación de la temporada de 1924 de los bailes rusos de Diaghilev en el Teatro del Liceo. Bibliothèque Nationale de France (BNF), département Bibliothèque-musée de I'Opéra, AID-931 (5, 158-167) [https://gallica.bnf.fr/ark:/12148/ btv 1 b84150583].

7 En Diario de Barcelona, 8 de marzo de 1924, p. 2411.

8 Ver La Vanguardia, 18 de marzo de 1924, p. 12. Carol Hess ofrece de forma más detallada la acogida de "El sombrero de tres picos" por el público español tanto en Madrid como en Barcelona. Ver, HESS, Carol, (2002), pp. 131-146. 
llantísimo de las grandes solemnidades artísticas y mundanas" que presentaría el "Teatro de la Opera" barcelonés con las novedades "El sombrero de tres picos"10 y "L'apres midi d'un faune". Completaron el programa las ya conocidas por el público del Liceo "Les Sylphides" y "Carnaval"."

El crítico de La Vanguardia Walter, que ya cubrió las representaciones de los bailes rusos en la anterior gira del 18, escribió una amplía reseña de la sesión inaugural donde celebraba el éxito alcanzado entre el público las danzas de los bailarines rusos. Tras comentar sus impresiones sobre "Les Sylphides", describió ampliamente "Carnaval" y "El sombrero de tres picos". De esta última obra criticó el vestuario y el decorado cubista de Picasso, por "feo" uno y "violento y abigarrado" el otro destacando la música de Falla porque reunía "lo más hondo de la música popular" con un final de obra acabado en Jota "rico en ritmos, algunos brutalmente gitanos". La representación, interrumpida varias veces por los aplausos del público, fue "ovacionada al final", marcando un fuerte contraste con el ballet que le siguió y cerró la sesión, "La siesta del fauno". ${ }^{12}$

9 Diario de Barcelona, 19 de abril de 1924, p. 7.

10 Lydia Sokolova, la bailarina que hizo el papel de la Molinera junto con Leon Woizovsky qque interpretó al Molinero) en "El sombrero de tres picos", explicaba en un libro sobre su vida la propia experiencia previa al estreno del ballet en Barcelona y de cómo el público estalló en aplausos al finalizar su actuación. Teniendo que salir varias veces a saludar al escenario: "Barcelona had never seen our Spanish ballet before, and we were very nervous. Eve Zoia Roszovska, who had sign to the accompaniment of our clapping hands before the curtain went up, was apprehensive of making a fool of herself in front of the critical public of the largest city in Spain. But no sooner was Picasso's décor revealed in all its warmth of lighting, with Leon alone on the stage making his first Spanish movements, than the audience settle down to watch us intently, and at the end of the first par they showed their enthusiasm by a tremendous burst of applause. By the end of the ballet they were worked up into a frenzy, and we took so many curtain calls that some of the dancers were dressed and on their way out of the theatre before Leon and I could leave the stage. We were very happy". SOKOLOVA, Lydia (1960), p. 220. Respecto a su papel de la Molinera en el ballet "El Sombrero de Tres Picos", en su biografía también habla de cómo se sentía más cómoda bailando este papel con Woizikovsky que con Leonidas Massine, el creador de la coreografía, porque aunque era una danza a dúo en muchos momentos de la obra, Massine parecía siempre estar bailando solos: "I preferred doing this baller with Woizikovsky, because Massine even he was dancing as my partner, always seemed to be dancing a solo", SOKOLOVA, Lydia (1960) , p. 176.

11 "Les inaugurals i les estrenes d'ahir. Liceu", La Publicitat, 20 de abril de 1924, p. 6. El orden de actuación fue: "Les Sylphides", "Le Tricorne", "L'après-midi d'un faune" y "Carnaval". Ver La Vanguardia, 19 de abril de 1924, p. 12. 
Joan Llongueras en La Veu de Catalunya -que ya siguió a la compañía rusa durante las giras del 1917 y 1918 en Barcelona- dedicó una extensa crónica a cuatro columnas, empezando con el recorrido histórico de la compañía de Diaghilev en el mundo de la danza y acabando, con una reflexión sobre la perdida de esa etiqueta de novedad artística permanente que siempre había acompañado a su espectáculo. Respecto a las cuatro obras de la noche centró su atención en "El Tricorni", cuyo decorado y vestuario, a diferencia de Walter, lo calificó de "elegantemente estilizado" y una "veritable meravella de intenció i color" debido a la ausencia de detalles y accesorios en el vestuario- lo que por otra parte facilitaba la movilidad de los bailarines. La crónica también recogía sus impresiones en lo referido a la música de Falla, la coreografía y la propia reacción del público tras finalizar la representación. Desconcertado a partes iguales tanto por la escenografía como por la no comprensión de la obra:

"La música de Manuel de Falla, que no té la malicía ni del decorat ni de la coreografía, és justa de carácter i poderosament evocadora i significativa.
Es teixida amb danses i temés populars éspanoyls, sense, però deixar d'acusar-se en ella el segell personal del fort temperament músical que la ha creada. Segueix i dóna el moviment just a totos el incidents de la faula i caracteritza admirablemente els personatges. La partitura és molt treballada $i$ escrita amb traça i amb perfecte coneixement desl moderns recursos harmònics. En l'orquestació potser s'hi nota una certa duresa i sequetat, segurament volguda, ja que a nosaltres no ens hi destroba gens, ans bé, acaba s'apoiar el seu caràcter. Remarquém que la dansa de la molinera, el fragment dels raïms, un dels més inspirat i característics de l'obra, la dansa del moliner i el brillant apoteòsic final. En la coreografía de Massine hi ha un humor i una ironía adorables $i$ és poderosament expressiva i plena de caràcter tota ella. Potser la constant repetició de moviments d'influencia marcadament epiléptica la perjudica. Notàrem, sobretot en la segona part, algunes petites variants en l'acció, que no correspon en del tot amb la intenció de la música i que ens semblaren defectes $d$ 'interpretació....

12 Walter, "Liceo. Bailes rusos", La Vanguardia, 20 de abril de 1924, p. 15. Ver más reseñas en FIVE, "Els Balls Russos de Diaghilew al Liceu", La Veu de Catalunya, 20 de abril de 1924, p. 4. 
El públic del Liceu, aplaudí "El Tricorni" i l'admirable interpretació dels dansaires russos, però l'obra no fou plenament gustada i compresa, sinó d'una no molt nombrosa selecció. La major part restà desoncertada per l'audacia del decorat i per la crua i subtil estilització de la coreografia i de la música, sense la més petita compensació al mal gust habitual". ${ }^{13}$

Siguiendo con los elogios al ballet español El Correo Catalán ${ }^{14}$ y otras cabeceras como el Diario de Barcelona o El Diluvio celebraron la acogida que tuvo entre los espectadores del Liceo en función de los aplausos ofrecidos a su conclusión. Así mientras A. M., desde las páginas del Diario de Barcelona, calificaba la representación como de españolada, achacando su impronta española a la música de Manuel de Falla, de la que además, puso en valor la modernidad que traslu- cía. ${ }^{15}$ Alard, el crítico de espectáculos teatrales del diario El Diluvio, también mostró su admiración por lo moderno de las notas musicales del maestro gaditano en el ballet remarcando, sin embargo, que no perdiese la esencia de la obra original:

"Con un lleno inaguróse anoche la temporada de primavera del Liceo: butacas y palcos atestados de mujeres bonitas y en los pisos altos también la concurrencia numerosa. La compañía coreográfica que dirige Serge Diaghilew presentóse con interesantísimo programa, en el que figuraba la primera representación del bailable de Martínez Sierra, adaptación del cuento de Alarcón, "El Sombrero de tres picos", música de Manuel de Falla, que fué un éxito completo. Verdaderamente, el maestro Falla ha escrito una partitura hemosísima, en la que

13 J. LL., "Els Balls Russos de Diaghilew al Liceu", La Veu de Catalunya, 20 de abril de 1924, p. 4.

14 M., "Liceo. Inauguración", El Correo Catalán, 20 de abril de 1924, p. 5.

15 "Trátase de una spagnolade, en la que el talento músico de Falla se manifiesta de manera brillante, con todas las características de las corrientes modernas, habiendo dotado a su partitura de una música grácil e instrumentada de mano maestra. Si bien, como hemos dicho, hay en "El sombrero de tres picos. todas la características modernas, no por eso deja de serpentear por en medio de las modernidades armónicas una melodía fresca y espontánea, que lleva bien marcado el sello de la música española". A.M., "Bailes Rusos", Diario de Barcelona, 20 de abril de 1924, p. 39. En sus notas de sociedad, en el diario se afirmaba que el "todo Barcelona elegante y aristocrático se había dado cita en el Liceo" en "Notas de Sociedad", Diario de Barcelona, 22 de abril de 1924, p. 5. 
se destacan gran variedad de ritmos y riqueza de colorido orquestal. Se manifiesta un músico de profundos conocimientos, y especialmente artista de culto y de refinada sensibilidad. La musicalización de "El sombrero de tres picos" es sorprendente por todos conceptos, y más en los tiempos presentes, que parece haberse olvidado todo sentido de forma y estructura. Con todo y rendir tributo a las formas modernas, no olvida el carácter y el sentido interno del libro. Hay momentos afortunadísimos en la orquestación, así como el detalle, que no puede ser más conciso". ${ }^{16}$

En cambio apenas una nota informativa contenía el diario La Publicitat sobre la noche del estreno de la compañía de Diaghilev en la sección "Darrera hora". Destacaba en sus páginas la obra "El tricorni" y el éxito "complet" que tuvo su representación, emplazando para unos días más tarde, un análisis más profundo del acontecimiento artístico que constituían los bailes rusos. ${ }^{17}$ Tras la función inaugural se sucedieron dos días seguidos de representaciones, el domingo 20 de abril en horario de matinée con las obras "Carnaval", "Cleopatra" y "Petrouchka"18 y el lunes día 21 en horario nocturno con los bailes "Les Sylphides", "L'aprés midi d'un faune", las danzas del "Príncipe lgor" $y$ "Le Tricorne". ${ }^{19}$

De estas sesiones " $X$ " escribió una crónica en La Publicitat que recogía lo más señalado de estos dos días de ballets en el Liceo donde destacaba sobre las demás obras "Petrouchka", calificada por el crítico como de "obra maestra" por la "profunda impresión que dejaba en los sentidos. No solo por el argumento de su libreto, sino también por la partitura de Stravinsky -ya conocida por los espectadores del Liceo. Era una "maravilla" en palabras del crítico que sumo sus elogios al resto de obras representadas durante estas dos jornadas con excepción de "L'après midi d'un faune" y su recepción tan ponderada por parte del público:

"L'après midi d'un faune" fou
rebut amb general aprovació
i elogis. Per la nostra part, in-

16 Alard, "Liceo. Bailes rusos", El Diluvio, 20 de abril de 1924, p. 46.

17 "En parlarem amb l'atenció que mereix", "Les inaugurals i les estrenes d'ahir. Liceu", La Publicitat, 20 de abril de 1924, p. 4.

18 A.M., "Gran Teatro del Liceo. Bailes rusos", Diario de Barcelona, 22 de abril de 1924, p. 14.

19 La Publicitat, 20 de abril de 1927, p. 7. 
sistim en mostar la nostra humil disconformitat. La sensació de calma i ensomni que sembla es vol produir, sospitem que es podría obtenir per altres mitjans que els emprats, els quals donen a la dança un caràcter "estàtic"-no "estètic" com ahir ens fèu dir el nostre benvolgut linotipista- que no podem comprendre". ${ }^{20}$

En una crónica teatral publicada el día 22 de abril, Joan Llongueras desde La Veu de Catalunya, analizó las obras representadas hasta esta fecha empezando por las tres novedades que había traído la compañía de Diaghilev a Barcelona por primera vez: "El Tricorni", "Petrouchka" y "La tarda d'un faune". Este último ballet, al igual que al crítico de La Publicidad, no convenció a Llongueras aunque en su caso por el decorado que era: "horriblemente, desentonat i míser". Mas mesurada fue su crítica a "Cleopatra" y a "Las danzas del príncipe lgor". Respecto a "Carnaval" y "Les Silfides"21 fueron las interpretaciones que menor interés tuvieron para el público a juicio del crítico. Concluía su crónica con una valoración general de la troupe rusa y la acogida del espectáculo por parte de los espectadores presentes durante estas tres noches de danza en el Liceo:

"L'actual companyia de Balls russos de Diaghilew, és en conjunt, força notable, i hi ha en ella algunes figures de relleu, no totes certament desconegudes per nosaltres. Citem en primer lloc les senyores Nijinska, Tchernicheva, Nemtchinova, Sokolva, Nikitina, De Valois, Schollar, Doubrovsky, etc, i els senyor Wilzak, Woizikovsky, Zverw, Slawinsky, Jarvinsky, Doline i Kremmec. Els ballets són posats sota la direcció personal de Serge Diaghilew, i del "regisseur" general, Serge Grigorieff. Dirigeix l'orquesta el mestre Eduard Flament, qui demostra conixer bé el repertori, però que segurament s'ha vist

20 X., "Balls russos, segona i tercera representacións", La Publicitat, 23 de abril de 1924, p. 4.

21 "Carnaval" i "Les Sílfides" en plauen cada vegada menys. El primer és una frívola i banal fantasía carnaalesca que no té res que veure amb la música tan espirítual de Schumann. El esgon, un seguit de motius de dansa purament decoratius, damunt uns valsos, unes mazurques i uns preludis de Chopin, no pas triats d'entre els millor que sols pot plaure i enternir les dames i damiselles romàntiques i sentimentals. No ens sembla tampo un encert el portar l'orquesta una música tan fondament pianística como aquesta de Schumann i Chopin". Joan Llongueras, "Companyia de Balls Russos de Serge Diaghilew", La Veu de Catalunya, 22 de abril de 1924, ed. matí, p. 4. 
obligar a posar les obres amb excess va rapidesa i s'això se'n ressenten fins ara totes les interpretacions orquestals. El públic del Liceu ha rebut molt bè i ha prodigat novament els seus entusiastes aplaudiments a aquesta famosa manifestació d'art que amb tant encert l' Empresa del Gran Teatre ha fet reapareixer ente nosaltres, constituint, ara com ara, la més forta i vibrant actualitat de la vida artística barcelonina". ${ }^{22}$

La siguiente función tuvo lugar el 22 de mayo con un cartel compuesto por "El Sombrero de tres picos", "Petrouchka" y "Cleopatra". Sobre esta sesión escribió J. B. de P. en El Correo Catalán, que al igual que los otros críticos de espectáculos, continuaba a vueltas con la música de Falla y la creación del ballet de inspiración española por Diaghilev por considerarla una "producción musical de primer orden". Para el crítico de El Correo Catalán, no era otra cosa sino la música lo que hacía brillar la representación por encima de la impronta cubista o la propia escenografía:

"Volviendo a la producción de Falla se impone desde luego reputarla no como una curiosidad de arte nuestro aplicada y vivificada en el ambiente de otro arte completo de genialidades rítmicas y arbitrariedades de diseño y color lque caracterizan el cubismo en que se presenta la obra), sino una producción musical de primer orden. Engendrada por el númen popular, saturada de "vis" emotiva dentro de lo que permite un género en que todo es incidental, tiene el arranque viril que distingue a las grandes personalidades: y a la belleza de los temas rebosantes de espontaneidad junta un técnicismo magistral pero claro y transparente para que las letras del autor no queden embrolladas en la percepción del oyente. A no haber sido por la música que es el nervio de esta exhibición de arte danzante no habría resultado éste en que el cubismo extrema las líneas caticaturescas que viéronse en el cuento de Alarcón "El corregidor y la molinera". Realmente en estos cuadros de bailes rusos el problema de producción ha sido doble o predominantemente de plástica visualidad. Mas en El Tricornio es ante todo musical.

La plétora de ritmos que la troupe va destriando en escena de-

22 Joan Llongueras, "Companyia de Balls Russos de Serge Diaghilew", La Veu de Catalunya, 22 de abril de 1924, ed. matí, p. 4. 
terminando la incesante variedad de siluetas en las figuraciones coreográficas palidecieron ante la valentía y plenitud de la partitura de Falla, para quién fueron en gran parte los aplausos demostraciones de agrado que se produjeron en la sala, sobre todo en la Jota final" ${ }^{23}$

El día 23 de abril la compañía de Diaghilev presentó como novedad de temporada la obra "Thamar, el estreno de la trilogía "Contes Russes", "Carnaval" y las danzas de "El príncipe lgor". Sobre esta sesión El Diario de Barcelona ${ }^{24}$ y El Diluvio destacaron las actuaciones de los bailarines y la respuesta de un público que estuvo "desorientado" ante la representación de "Contes Russes":

"Anoche dióse por vez primera el "ballet" mímico de Liadow "Cuentos rusos", formado por una serie de episodios, algunos de ellos muy interesantes como cuadro plástico y nota de color. Claro que el público, un poco desorientado por no conocer el asunto ni el argumento que se estaba desarrollando mostró más de una vez sus reservas, más, sin embargo, el nuevo cuadro representado no puede negarse que tiene momentos muy apreciables, y sobre todo los artistas rusos estuvieron excelentes, distinguiéndose las señoras Nifinks, Tchernicheva, Korolovitch y los señores Weizikowsky, Sinvisky y Wilzak. La música del maestro Liadow es notable por su brillantez orquestal, aunque en algunos momentos languidece" ${ }^{25}$

Además J. Llongueras en La Veu de Catalunya, que también reflejo la pasividad de los espectadores durante la representación de "Contes Russes" -no muy aplaudida-, abría su crónica de la noche preguntándose sobre la falta de novedades en la programación de la compañía de Diaghilev. Reivindicaba así el crítico musical el ambiente moderno y avanzado de la vida artística barcelonesa comparable, en su vertiente musical, al de cualquier otra sociedad destacada del mundo artístico: "Sempre es troba en aquest
prodigiós espectacle quelcom
de sorprenente i d'inesperat.
Val a dir que ès això precisa-
ment allò que hi anem a cercar
i allò que voldriem ens haguès
sigut donat amb mès prodigali-
tat en aquesta actual "tournée"

23 J. B. de P., "Liceo. Bailes rusos", El Correo Catalán, 23 de abril de 1924, p. 3.

24 A.M, "Gran Teatro del Liceo. Bailes Rusos", Diario de Barcelona, 24 de abril de 1924, p. 39. 25 "Liceo. Bailes Rusos", El Diluvio, 24 de abril de 1924, p. 39. 
entre nosaltres. Obres del gènere "Thamar", que fou represa ahir a la nit, amb música (certament ben fluixa) de Balkirew, coreografía de Fokine i decorat i vestuari de Bakst, ha no ens poden interessar perquè res de nou ens aporten i l'emoció que ens podrien podruir és ja gastada i esmosada fa temps. La interpretació que donen a aquest ballet o drama coreogràfic els artistes russos és, com totes, ben notable i per això ens dol encara molt més que, tenint en compte la curta estada que fan en nostra ciutat, no esmercin les seves habílitats $i$ el seu talent $i$ el seu art en aquelles coses fortes i personal que consitueixen el "clou" del seu vast repertori. Ens referim a tota aquella sèrie de Ballets amb música de Ravel, de Straus, d'Erik Satie, de Strawinsky i d'altres autors mo- dernísims que han deixat la seva aportació magnifica a aquesta experiència artística tan plena de suggestions i revellacions; que és el "Ballet Rus". Diaghilew cal que s'adoni que hi ha a Barcelona una intensa vida artística que vibra a l'uníson amb l'ambient més avençat del món. L'exit recent de Strawinsky és un fet certament revelador." 26

El día 24 la sesión en horario nocturno comenzó con los ballets en un acto "Sylphides", "Thamar"27 $y$ "Contes russes" y con el estreno de "Cimarosiana", ${ }^{28}$ muy bien recibido por el público. ${ }^{29}$ El sábado 26 el programa lo componían "Petrouchka", "Pulcinella", "L'après-midi d'un faune" y las danzas de "El príncipe lgor". ${ }^{30}$ "Pulcinella", el estreno de la noche, creó críticas dispares en los diferentes medios que venían siguiendo la evoluciónes de

26 Joan Llongueras, "Balls russos de Diahilew", La Veu de Catalunya, 24 de abril de 1924, p. 7.

27 Walter valoraba la obra integra en su conjunto porque no creía que la música ni la coreografía tuvieran un "gran interés" si bien las posibilidades escénicas que la danza ofrecía al público eran de agradecer. Aunque muchos los espectadores no le prestaron la atención que la representación "merecía". Walter, "Liceo. Bailes Rusos", La Vanguardia, 25 de abril de 1924, p. 17.

28 X. "Liceu. Balls russos. Cimarosiana", La Publicitat, 27 de abril de 1924, p. 6.

29 A.M, "Gran Teatro del Liceo. Bailes Rusos", Diario de Barcelona, 25 de abril de 1924, p. 31 . En páginas anteriores a la crónica teatral también se aseguraba que no se prolongaría el contrato de la compañía de los bailes rusos en Barcelona al tener ya la compañía de Diaghilev contratos cerrados en Holanda, París y Londres. "Teatros y Cines", Diario de Barcelona, 25 de abril de 1924, p. 14.

30 La Publicitat, 26 de abril de 1924, p. 8. 
la compañía rusa con una resonancia en la prensa, por la colaboración de Picasso, casi comparable a la generada por "El sombrero de tres picos". "X", en La Publicitat destacó por encima del decorado de Picasso y la coreografía de Massine, el vestuario y la colaboración vocal de Concha Callao y Dimi i Giralt en la representación junto con el gran trabajo de los bailarines Woizikovsky y Sokolova sobre el escenario. ${ }^{31}$

Las crónicas de El Diluvio el día 27 de abril ${ }^{32}$ y del Diario de Barcelona el 29 de abril de 1924 respectivamente, también recogían el estreno de "Pulcinella" con críticas al decorado. En este último periódico se destacó la interpretación de Woizikovsky y la gran solvencia de la orquesta bajo la dirección del maestro Flament, aunque para el cronista, Picasso podría haber dado "más de sí" en la creación del decorado bajo las "teorías cubistas":

"Si bien en cuanto al decorado del "ballet russo" estamos conformes y juzgamos una necesidad salirse del realismo, e incluso ampararse en las teorías cubistas, creemos, no obstante, que Picasso hubiera podido dar más de si en "Pulcinella", que, en verdad se presta en gran manera y da lugar a mayores agudezas de construcción y color... Strawinsky puso en la partitura de "Pulcinella" un sin número de dificultades, obligando a cada instrumento de por sí a dar todo el rendimiento posible y obligando al conjunto orquestal a actuar con dificultades de solista. Estos escollos supieron salvarlos los profesores de la orquesta y no menos el maestro Flament, que con acierto la dirigió".$^{33}$

Por su parte B. de P. en El Correo Catalán mostró interés y valoró la adaptación que Igor Stravinsky había hecho de la partitura de Pergolesi -ya conocida por parte de los asiduos al Liceo- y su orquestación para ballet, aunque también reflexionaba sobre el trabajo realizado por el compositor ruso en un proceso de adaptación "caricante" porque había derivado en una mayor dificultad técnica en su ejecución musical:

"Ha sido el último estreno de los bailes rusos. Interesaba mucho esta obra "sui generis" puesto que en los conciertos de Strawinsky se dió una "suite"

31 "A.", "Balls russos. Pulcinella", La Publicitat, 29 de abril de 1924, p. 4.

32 "A.", "Liceo. Bailes rusos", El Diluvio, 27 de abril de 1924, p. 27.

33 "Bailes rusos. Estreno de Pulcinella", Diario de Barcelona, 29 de abril de 1924, pp. 9-10. 
compuesta de fragmentos de aquella; y según dijimos en la reseña obligada y con la satisfacción de consignas unéxito, "Pulcinella" es una partitura tejida por el genial compositor ruso con música del clásico napolitano J. Battista Pergolesi. Dada ahora la obra por completo y con el aliciente de la representación danzante se echa de ver pronto que el capricho de Strawinsky va a derivar en caricatura; y así como el caricaturista al exagerar los rasgos de la fisonomía y al fantasear grotescamente con la silueta del caricaturizado, le reconoce la importancia, Strawinsky rinde pleitesía al músico italiano, "caricando" enormemente los rasgos característicos de su época y sus formas musicales y transcribiendo pulcramente melodías pergolesianas; pero escapa, también al terreno peligroso de la arbietrariedad armónica y rítmica del cual vuelve a salirse muy airoso.... Esto último hace también difícil una ejecución cabal de la partitura de "Pulcinella", verdaderamente erizada de asperezas en ciertos pasajes de los instrumentistas". ${ }^{34}$

Por último Walter en La Vanguardia encontró en "Pulcinella" una obra que "divirtió" al público con su escenografía y música a la que calificó de caricaturesca. ${ }^{35}$ Pero esta diversión para el espectador de la que hablaba Walter, provocada por interpretación de los bailarines y la propia escenografía del ballet, no evitó la confusión del público ante lo visto en el escenario del Liceo, y como en noches anteriores, la reacción de los espectadores fue de desconcierto, hecho que también confundió a los propios redactores de La Publicitat. ${ }^{36}$ La siguiente función fue fijada el 29 de abril de 1924 a las nueve y media con un nuevo estreno en cartelera "Dafnis y Cloe", aunque abrió la noche "Cleopatra". Completaron el cartel "Carnaval" y "Cimarosiana". ${ }^{37}$ En el estreno de "Dafnis y Cloe" con música del compositor Maurice Ravel, coreografía de Michel Fokine, escenografía de Leon Bakst y vestuario de Juan Gris, fueron las interpretaciones de los bailarines principales de la compañía como

34 B. de P., "Liceo. Pulcinella", El Correo Catalán, 30 de abril de 1924, p. 3.

35 Walter, "Bailes Rusos. Pulcinella", La Vanguardia, 27 de abril de 1924, p. 21.

36 "No es dirá aquesta vegada que les audacies del músic puguin inspirar cap desconfiança, ni la interpretació coreográfica no presenta tampoc cap complicació ni el vestuari és d'un cubisme alarmant...Però, malgrat tot això, els aplaudiments de l'auditori tingueren un to d'indecisió incomprensible". "Darrera hora. De Barcelona. Liceu", La Publicitat, 27 de abril de 1924, p. 8.

37 La Publicitat, 29 de abril de 1924, p. 7. 
Lydia Sokolova ("Cloe"), Antonio Doline ("Dafnis"), Nicolas Zverev ("Darkon") o Maikerska ("Lyccion") lo que más destacó la mayoría crítica barcelonesa. En cambio para Walter en La Vanguardia, fue la dirección del maestro Flamenent al frente de la orquesta del Liceo lo más destacable de la sesión: "realizo un excelente trabajo, verdadero tour de force dadas las dificultades de la partitura" ${ }^{38}$ No tuvo la misma opinión Joan Llongueras porque, a diferencia de Walter, calificó de "discreta" tanto la dirección musical de Flamenent como la interpretación del bailarín principal Antoine Doline. Sin embargo, como crítico con una gran formación musical firmó un extenso análisis de todos los elementos musicales de esta obra de Ravel a la que calificó de "magnífica sinfonía coreográfica". Pensaba Llongueras que era una de las producciones "más fuertes" de todo el repertorio de ballets de Diaghilev:

"Deixant a part el ballet i l'acció escènica, "Dafnis i Cloe" de Ravel pot considerar-se musicalment com una poderosa i ben construïda simfonia escrita per un dels més brillants i suggestius virtuosos de l'orquestra moderna. Es divideix aquesta obra en tres temps i dos intermedis. Allò que caracteritza els temps és l'acció, és la faula poemàtica, que Ravel segueix i comenta pas a pas amb fina i lúcida musicalitat, sense, però caure mai en descriptivismes fàcils i vanals" ${ }^{39}$

" $\mathrm{X}$ ", desde las páginas de La Publicitat, al igual que Llongueras dedicó una extensa crónica "Dafnis i Cloe" a la que consideraba como "un dels blocs més ferms de la música contemporània i com una de les manifestacion més significatives i reeixides de l'art francès" debido a la música de Ravel. Aunque en su opinión la partitura creada por Ravel no era escenificable, como otras producciones del repertorio de Diaghilev, pese a que consideraba las danzas de esta obra como una "veritable delicia",

"Renunciem per avui a les disgressions que hauríen de fer per fonamentar la nostra manera d'apreciar aquesta producció i expressar del tot el nostre pensament, i comencem per on hauríem acabat. Diguem-ho clar: la coreografía, o, més precisament, la plàstica ens hi fa nosa. No que la interpretació de Fokine no sigui admirable en tots el sentits, interessantísima

38 Walter, "Bailes rusos. Dafnis y Cloe", La Vanguardia, 30 de abril de 1924, p. 18.

39 J. LL, "Balls russos de Diaghilew. Dafnis i Cloe", La Veu de Catalunya, 2 de mayo de 1924, p. 4. 
com a realització r'timica i plena de subtileses que s'adiven amb el caràcter de la musica; sinó que per a nosaltres aquesta música no és del tot "interpretable" plàsticament, i el tema que glossa no ens expliquem, que almenys reduit en la forma que ens és essencial, com ha pogut temptar a Ravel per portar-lo a l'escena...Al començament de les sessions de Balls Russos i a propósit d'algunes representacions que no ens van plaure, insinuàrem que ens sembla un error creure que a tota la musica i a totes les obres musicals escau la interpretació plàstica o la coreografia. Ara podem insistir en al nostra apreciació, afegint ecara que fins moltes obres escrites amb aquest intent tot $i$ essent ben reeixides sota determinat aspecte, podem no reunir condicions pe a l'escena, equivocant-se l'autor i fracassante en l'assaig si no està especialment preparat per al gènero 0 no té encert a triar el tema. Prescindint ara d'aquests punts de vista, hem de dir que la musica de "Dafnis i Cloé" és una meravella de capa a cap". ${ }^{40}$
Las sesiones de despedidas de bailes rusos del Gran Teatro del Liceo para esta temporada de 1924 se programaron a las 21:30 horas el día 30 de abril, miércoles, con las obras "Carnaval", "Dafnis y Cloe", "Pulcinella" y las danzas de "El príncipe lgor" 41 y el jueves 1 de mayo con un cartel final de actuaciones que se configuró con "Sylphides", "Cleopatra", las danzas de "El príncipe lgor", y "Le Tricorne". ${ }^{42}$

\section{Año 1925. Nuevos tiempos: la RADIO Y EL FC BARCELONA}

Un año más tarde, en mayo de 1925, volvían los bailes rusos al Gran Teatro del Liceo con un imprevisto que afectó a la planificación de la temporada a su llegada a Barcelona. Anunciados los nuevos espectáculos de la compañía de Diaghilev desde el mes de abril, la empresa que gestionaba el teatro barcelonés exigió el cambio en la dirección de la orquesta del maestro François Defosse antes del inicio de las sesiones. ${ }^{43}$ Así una vez ya configurado el plantel definitivo de la compañía para su gira en Barcelona la función inaugural se programó el sábado 2 de mayo a

40 "X", "Liceu. Balls Russos. "Dafnis i Cloè", La Publicitat, 2 de mayo de 1924, p. 4.

41 La Publicitat, 30 de abril de 1924, p. 8.

42 La Vanguardia, 1 de mayo de 1924, p. 13.

43 Al parecer la empresa Mestres que gestionaba el Liceo se negó a aceptar a Defosse como director de orquesta lo que motivo la contratación de Eugenio Goosens en BUCKLE, Richad (1984), p. 453. 
las 21:45 con las obras "Les sylphides", el estreno en España de "Les tentations de la Bergère", "Cimarosiana" y "Scheherezade". ${ }^{44}$ Como novedad extraordinaria, respecto a temporadas pasadas, las representaciones de los ballets russes en el Liceo fueron trasmitidas por primera vez en directo en España desde la frecuencia de Radio Barcelona. ${ }^{45}$

\section{La Veu de Catalunya ${ }^{46}$ y el Diario} de Barcelona recogieron en sus respectivas secciones de espectáculos el debut de la compañía rusa, destacando la colaboración en decorados y vestuario del pintor catalán Juan $\mathrm{Gris}^{47}$ junto con las interpretaciones de los bailarines:

"Como estreno constaba "Les tentationes de la Bergere", música de Monteclair, reconsituída e instrumentada por H. Casadesús y coreografía de Nijinksy. Su música que lleva toda la claridad y frescura clásicas, unida a la riqueza de color de los trajes y la magnífica interpretación que obtiene, hacen de este ballet una preciosa escena. Fué (sic) acogido cono mucho agrado. Muy aplaudidos fueros todos los interpretes y especialmente las partes principales señoras Tchernicheva, Nikitina, Coxom, Sanina, Nemtchinova, Doubrowska, Nima de Valois, Sokolova y señores Woizikowsky. Ydzkowsky y Doline todos los cuales realizaron la exquisita labor que corresponde al renombre alcanzado por esta compañía. Constituyó, pues, la función de anoche un nuevo éxito que pueden apuntarse los tan notables bailarines rusos" ${ }^{4}{ }^{4}$

44 Programa de la función inaugural del día 2 de mayo de 1925, BNF, département Bibliothèque-musée de l'Opéra, AID-931 15, 320-342) [https://gallica.bnf.fr/ark:/12148/btv1 b8415069w].

45 "Retransmisión de los bailes rusos cuya presentación tendrá lugar hoy en el Teatro del Liceo". La programación del día se puede ver en la sección de Radiodifusión del Diario de Barcelona, 2 de mayo de 1925, p. 34. Radio Barcelona (EAJ-1), se inauguró el 14 de noviembre de 1924 con un discurso transmitido en directo del Alcalde de Barcelona teniendo como sede el Gran Hotel Colón. La Vanguardia, 14 de noviembre de 1924, p. 4. El Reglamento de Radiodifusión a nivel nacional entró en vigor 5 meses antes el 14 de junio de 1924. Ver más en GARITAONAINDIA, Carmelo (1988), pp. 19-21.

46 "Les temptations de la pastora o el triomf de I'amor", La Veu de Catalunya, 3 de mayo de 1925, p. 8.

47 Juan Gris tuvo su primer contacto con Diaghilev en enero de 1917 en París, con ocasión de la venta de unos cuadros. Gris que residía en París en esos años, compartía con el también pintor Diego Rivera marchante de arte y relaciones comunes con otros artistas de las vanguardias parisinas que frecuentaban los cafés de Montparnasse. Ver, GRIS, Juan (2008), pp. 134-114. 
La siguiente sesión programada en horario matinée el día 3 de mayo traía un nuevo estreno para el público del Liceo "Le train blue". Completaban el cartel "Cimarosiana", "Scheherezade" y las danzas de "El príncipe lgor". ${ }^{49}$ Walter, desde las páginas de La Vanguardia centraba su crónica en la novedad de la noche..$^{50}$ Por su parte, B. de P. en El Correo Catalán dejaba sus impresiones de las dos primeras jornadas de bailes rusos en Barcelona en una crónica protagonizada por los estrenos de la nueva temporada "Les tentations de la Bergère" y "Le train bleu". En ella criticó de forma amplía "Le train bleu", la obra ideada por Jean Cocteau, porque a su juicio no tenía mucha cabida en la idiosincrasia del teatro barcelonés a diferencia de otras obras de la compañía de Diaghilev:

"Otro estreno ha sido "Le train bleu", música de D. Milhaud. Se trata de la adaptación de una opereta, excesivamente ligera para el Liceo, aunque que se tenga en cuenta que se halla el espectador en el ambiente coreográfico. En el noble marco del primer teatro barcelonés desentona el asunto de la obri- ta, aunque el público la aceptó benevolamente y no dejó de aplaudirla. El arte serio vióse pronto desquitado en "El Príncipe lgor" y anteriormente en "Cimacorianas" y en "Shcherazade" pudro brillar en todo su prestigio, merced a la importancia de sus partituras y a la excelencia de los varios factores que determinan el espectáculo excepcional, es decir único de los "Bailes rusos". 51

Otra visión del estreno la aportó A.M en el Diario de Barcelona, quién aunque consideró la música de Milhaud algo "trivial" era, sin embargo, la adecuada conforme al argumento del ballet:

"Le train bleu' son una serie
de escenas de playa en las que
diferentes sports y juegos son
interpretados coreográficamen-
te, adquiriendo un animado y
bello conjunto. La música que
ha escrito Darius Milhaud, aun-
que de carácter algo trivial se
adapta con su animado ritmo
al ambiente del asuno. "Le train
bleu" gustó, y admiróse el arte
de los tan notables bailarines

48 A.M., "Debut de la compañía de bailes rusos", Diario de Barcelona, 3 de mayo de 1925, p. 39.

49 La Publicitat, 3 de mayo de 1925, p. 9.

50 Walter, "Bailes rusos. Le train bleu", La Vanguardia, 5 de mayo de 1925, p. 14. Ver reseña sobre esta sesión en CASTILLO, Pedro (2017), p. 258.

51 B. de P., "Bailes Rusos. Liceo", El Correo Catalán, 5 de mayo de 1925, p. 2. 
rusos que en esta obra como en todas están notabilísimos". ${ }^{52}$

\section{El 5 de mayo a las 21:30 horas} se representaron "Les tentations de la Bergère", "Carnaval", "Le train bleu" y "Cleopatra". ${ }^{3}$ El miércoles 6 de mayo el cartel lo formaron las obras "Scheherezade", "Contes russos", "Carnaval" y la danzas de "El príncipe lgor". ${ }^{54}$ El Diluvio, que no había publicado nada hasta la fecha sobre las actuaciones de los bailes rusos este año de 1925, reflejaba en su sección de espectáculos el éxito de público que estaban teniendo:

"Los bailes rusos es algo que seduce. Díganlo sino los entradones que se han registrado estos días en el Liceo, lo que demuestra el buen gusto de nuestro público, no ya 'solo en lo que podríamos llamar de nuestra aristocracia, sí que también en honor a la verdad del público popular, que, abigarrado en los pisos altos, ha hecho ostentación de su alto criterio artístico premiando con calurosos aplausos una actuación que sólo ha tenido de censura el hecho de dar tan pocas funciones". "La actuación de la compañía de bailes rusos en el Liceo. ${ }^{55}$

El día 7 jueves a las 21:30 se abrió la sesión nocturna con "Cimarosiana", seguida de la novedad "Le mariage d'Aurore" y cerraron la función "Le train bleu" y "Cleopatra" ${ }^{56}$ Respecto al estreno de la noche B. de P. en El Correo Catalán describía "Las bodas de Aurora" como una "producción que merecía el aplauso" pese a que no era nada "extraordinaria" y contaba con una música que servía de "pretexto" al género principal de esta obra: "la danza". En la representación sobresalió por encima de los demás bailarines Vera Nemtchinova. ${ }^{57}$ Distintas opiniones tuvieron los redactores de La Vanguardia ${ }^{58}$ y

52 A. M., "Gran Teatro del Liceo. Bailes Rusos", Diario de Barcelona, 5 de mayo de 1925, p. 24.

53 La Publicitat, 5 de mayo de 1925, p. 9.

54 Diario de Barcelona, 6 de mayo de 1925, p. 32.

55 El Diluvio. 7 de mayo de 1925, p. 3. Curiosamente misma nota de prensa se reproducía idéntica en el diario El Correo Catalán, bajo el título "El Liceo y los Bailes Rusos", el día 10 de mayo de 1925, p. 2. Ver también la crónica de Walter, "Las bodas de Aurora-Cuentos de hadas", La Vanguardia, 8 de mayo de 1925, p. 16.

56 La Vanguardia, 7 de mayo de 1925, p. 14.

57 "Balls russos. Le mariage d'Aurores", La Veu de Catalunya, 8 de mayo de 1925, p. 8.

58 Walter, "Las bodas de Aurora-Cuentos de hadas", La Vanguardia, 8 de mayo de 1925, p. 16. 
el Diario de Barcelona ${ }^{59}$ porque en sus respectiva crónicas, destacaron la coreografía y las buenas interpretaciones del cuerpo de baile de la compañía y en concreto, en este caso al igual que El Correo Catalán, de Vera Nemtchinova.

El sábado 9 de mayo el cartel se compuso de los ballets "Contes russes", "La boutique fantastique" (estreno), "Le mariage d'Aurore", y las danzas de "El príncipe lgor". 60 Las crónicas de la sesión aparecidas tanto en La Vanguardia como en La Veu de Catalunya subrayaron la orquestación que se hizo de la obra original de Rossini para "La boutique fantastique". Para el cronista de La Veu de Catalunya lo mejor de la obra era, sin dudas, la música para el ballet a la que cali- ficó de "potpourri". Algo habitual, por otro lado, en la compañía rusa porque creaba la producción musical a partir de la partitura de un autor, en esta ocasión Rossini, y la orquestaba para su representación en ballet otro músico distinto (Ettorio Respoghi). ${ }^{61}$ En cambio Walter en las páginas de La Vanguardia señaló la composición de Rossini como de "superior" en comparación a la "ampulosamente hueca" música de Tchaikovsky orquestada para "Le mariage d'Aurore". Con una bien ejecutada parte musical por el maestro Goosens a cargo de la orquesta del Liceo, fue la coreografía lo más interesante del estreno de la noche a pesar de su "pueril argumento". ${ }^{62}$ La interpretación "gustó" y fue "muy aplaudida" por el público. ${ }^{63}$

59 "Bailes rusos. Estreno Le mariage d'Aurore", Diario de Barcelona, 9 de mayo de 1925, p. 18.

60 La Publicitat, 9 de mayo de 1925, p. 7.

61 "Balls russos. La boutique fantastique", La Veu de Catalunya, 10 de mayo de 1925, p. 4. Respecto a la música de "La boutique fantastique", también El Correo Catalán, alababa la transformación de la partitura de Rossini realizada por Respighi, calificando su propuesta de "modernidad relativa": "La facilidad melódica de Rossini que nadie pueso en duda ha venido aun ha corroborarlo hace pocos días en alguna de sus obras reproducidas según su peculiar manera en el "Teatro dei Piccolí" que actuó en el Goya y por "La Boutique fantasque" a cuyos temas prestó mucho relieve el maestro Respighi, aplaudido autor de "Le fontane di Roma" al reinstrumentar una sencilla obra musical y aderezarla armónicamente dentro de unos límites que sólo implican propósitos de modernidad relativa. Así procedía y la agradable partitura prestase a la variadísimas suites bailable en la cual hay de todo como en botica, pero no decae nunca en interés artístico-coreográfico y suscita en todos o en casi todos sus número los aplausos espontáneos del público", B. de P. "Liceo", El Correo Catalán, 12 de mayo de 1921, p. 6.

62 Walter, "Bailes rusos. La boutique fantastique", La Vanguardia, 10 de mayo de 1925, p. 19.

63 "Estreno de La boutique fantastique", Diario de Barcelona, 13 de mayo de 1925, p. 17. 
El lunes 10 de mayo se representaron "Carnaval", "El lago de los cisnes" y "Scheherezade". El estreno de un ballet como el "Lago de los cisnes" con música de Tchaikovsky, coreografía de Marius Petipa y decoración de Korovine y Golovine no producido bajo la idiosincracia diaghileviana, no satisfizo a la crítica ni a los espectadores del Liceo, acostumbrados ya a la "modernidad escenográfica" de las producciones del empresario ruso. Sobre este hecho tanto las crónicas de La Veu de Catalunya ${ }^{64}$ y de La Vanguardia ${ }^{65}$ coincidían en considerar el ballet de Petipa como una obra con poco interés para el público (creía la crítica que fue creada para lucir las habilidades coreografías de los bailarines). En la misma línea, "A.", desde El Diluvio, incluso llegaba a cuestionar la propia autoría de Tchaikovsky en el ya ci- tado "El lago de los cisnes":

"Poca cosa tiene de notable la música de este "ballet", firmada por fragmentos de composiciones del maestro Tchaikowsky, que precisamente parece que se hayan escogido los trozos más triviales y banales que el compositor rusos escribiera. Por otra parte, el asunto es también un poco cursi, no teniendo de notable nada más que las acertadas escenas coreográficas, combinadas todas ellas con el acierto y el buen gusto característico de la compañía de Diaghilev...Lo demás, como hemos indicado, todo muy languido y hasta pesado, sobre todo el segundo acto. Hasta llegamos a suponer que toda la música no pertenece a Tchaikowsky". .6

64 "Balls russos. Le lac des cygnes", La Veu de Catalunya, 13 de mayo de 1925, p. 3.

65 Walter a pesar de calificar este ballet de vulgar le causó buena "impresión" la puesta en escena por la "bella realización plástica de los grupos de mujeres-cisnes, de un efecto encantador de una suavidad de líneas y de colores del más refinado gusto". A ojos del crítico de La Vanguardia, salvaron el estreno las grandes interpretaciones, a diferencia de la música, de Anton Doline y Stanislao Ydzikovsky, que junto a Vera Netmchinova, Alice Nikitina, Alexandra Danilova o Lidia Sokolova fueron los grandes ovacionados de la noche: "Era una idealidad estética que para llegar a su grado máximo sólo requería de una música más distinguida más evocadora. La belleza de las actitudes y de los conjuntos, logrados por las artistas todo es muy difícil de superar, al revés de lo que ocurre con la realización sonora de Tchaikowsky. ¡Cómo echamos de menos las ricas sonoridades y la exhuberante fantasía que caracterizan "El pájaro de fuego. Servían de marco al Lago el Carnaval y Scherezade. O sea un marco infinitamente superior al lienzo". "Bailes rusos. El lago de los cisnes", La Vanguardia, 13 de mayo de 1925, p. 15.

66 "A.", "Liceo. Bailes rusos. Le lac des cygnes", El Diluvio, 12 de mayo de 1925, p. 39. Otras cabeceras como El Correo Catalán pasaban por encima de análisis escenográficos y musica- 
La última de las funciones de abono programada de esta temporada de primavera del año 1925 tuvo lugar el martes 12 de mayo con las obras "Les Sylphides", "Petrouchka", "Le mariage d'Aurore" y las danzas de "El príncipe lgor". Sin reseñas en las crónicas periodísticas tras esta sesión, la compañía de bailes rusos prolongó su estancia en el liceo durante dos noches más de lo previsto en su planificación inicial. La primera de ellas gracias a los éxitos deportivos alcanzados por el Fútbol Club Barcelona.

La noche del 13 de mayo el teatro Liceo que lucía con la fachada decorada con "luces eléctricas" y con los colores del equipo "Fútbol Club Barcelona", fue el lugar escogido para homenajear al reciente campeón de los campeonatos de fútbol de España y de Cataluña. ${ }^{67}$ El acto consistió en un programa mixto de obras de ballet y piezas para música de orquesta. Los jugadores del Barcelona a su llegada al Liceo fueron recibidos a en el foyer del salón por el propio empresario del liceo
Joan Mestres y el antiguo líder de la Lliga Regionalista, y miembro de la Junta de Propietarios, Bertrand i Serra. Todos ellos, junto con el presidente del equipo Joan Gamper ocuparon dos palcos reservados en el segundo piso del anfiteatro engalanados con los colores azul y grana. Accedieron a ellos una vez comenzada la sesión cuando se interpretaba "El lago de los cisnes", que abrió la velada, siendo interrumpida por el gran aplauso con el que fueron recibidos los jugadores al ocupar sus localidades. ${ }^{68} \mathrm{~A}$ continuación de esta obra siguió la actuación de la Banda Municipal dirigida por Lamonte de Grignon que interpretó la pantomima de la obra "Las Golondrinas", las sardanas "A la plaça", "La Rosa del folló" y la "Obertura de Tannahauser". Cerró la noche el ballet "Le train bleu". ${ }^{69}$

Tras esta sesión homenaje al FC. Barcelona llegó la función de despedida de los bailes rusos del Gran Teatro del Liceo que tuvo lugar el jueves 14 de mayo con la programación de las obras "Schehereza-

\footnotetext{
les tan ajustados a la representación para justificar en líneas generales la calidad y ejecución de la compañía de bailes rusos. Destacando otros aspectos de la obra como la difícil interpretación que tuvo que realizar el violinista Munné de algunos fragmentos de la partitura pese a no estar ni la música ni la obra a la altura de otros ballets de la compañía. "B.", "Liceo. Bailes rusos", El Correo Catalán, 14 de mayo de 1925, p. 4.

67 La Publicitat, 12 de mayo de 1925, p. 10.

68 "Homenaje al F.C. Barcelona", El Diluvio, 14 de mayo de 1925, p. 39.

69 "Gran Teatro el Liceo. Función homenaje al F.C. Barcelona", Diario de Barcelona, 14 de mayo de 1925, p. 31.
} 
de", "Cuentos rusos", "Petrouchka" y las danzas de "El príncipe lgor". ${ }^{70}$ Aunque la mayoría de la prensa celebró la buena acogida por parte del público, la compañía de Diaghilev lamentó que la empresa de Mestres no hubiera podido llegar a un acuerdo con el empresario ruso para una última función extraordinaria. En ella se hubiese representado "La Leyenda de Joseph" con motivo de la visita de los reyes de España a Barcelona, en concreto en los días que van del 26 de mayo al 4 de junio. ${ }^{71}$

\section{Año 1927. La ÚlTIMA GIRA}

Después de actuar en la recién inaugurada temporada de primavera en Montecarlo y con previa parada en Marsella, los Bailes Rusos de Diaghilev reaparecían en Barcelona dos años más tarde un sábado 7 de mayo. ${ }^{72}$ El programa del estreno se configuró con "Les Sylphides", la novedad "Les matelots" y la "La boutique fantastique". ${ }^{73}$ A.M, en el Diario de Barcelona, sin entrar en una valoración más profunda en el caso de "Les Sylphides" o "La boutique fantastique", centró su crónica en el estreno de "Les matelots" porque era una creación de Boris Kochno que llevaba el puño de Pedro Pruna en la autoría del decorado. No obstante ni la música de George Auric ni la escenografía del pintor catalán, a las que calificó de gusto de "ultima hora", 74 tuvieron una valoración positiva por parte del crítico teatral. Tan solo la actuación de los bailarines hicieron que la representación no perdiera su interés:

70 La Publicitat, 13 de mayo de 1925, pp. 7-8.

71 "Declaraciones del Marqués de Viver", Diario de Barcelona, 16 de mayo de 1925, p. 28.

72 Diaghilev solo estuvo la primera semana de representaciones en el Liceo porque se tuvo que marchar a París a trabajar en una posible celebración del XX aniversario de los ballets russes. BUCKLE, Richard (1984), p. 457.

73 La Publicitat, 7 de mayo de 1927, p. 12.

74 También " $X$ ", desde las páginas de El Diluvio, hablaba de los bailes rusos como un espectáculo vanguardista, cuya obra "Les maletots", era fiel reflejo de ese espíritu: "Espectáculo para el regalo de los sentidos, de vagas sensaciones epidérmicas, pero salpicado de "esprit" y orientado casi siempre en un gusto muy " $D$ 'avant-garde", como ocurre en el ballet "Los marineros"...", X., "Bailes rusos de Diaghilew", El Diluvio, 8 de mayo de 1927, p. 36. 
A ésta, en el "Ballet" "Los marineros" le salva la vivacidad rítmica. Pero todo lo que pudiera decirse de la música y del decorado queda velado ante la labor admirable que realizan las señoras Danilova y Petrova y señores Woizikovsky, Slavinsky, Lifar y Cieplmsky. Hay verdadero espíritu en la mímica danzada de estos artistas. Por esto el "ballet" "Los marineros" no pierde en ningún momento el interés y por esto el público aplaudió mucho al terminar su representación". ${ }^{75}$

De la misma opinión era el cronista de El Correro Catalán B. de P., era el ritmo de la coreografía lo que hacía que la representación mantuviera su interés:

"Los ritmos originales y de gran vitalidad adecuados a un sentido de inquietud discolada y a veces de armonía muy disonante, sostienen el carácter de la obra, imbuída en una interpretación cubista de la pantomima y del bailes, forma muy gene- ralizada en estos espectáculos, que alguna vez derivan en licencia más aparente que real, ya que el asunto de ellos es de admirable amenidad". ${ }^{76}$

En cambio críticos como Joan Llongueras en La Veu de Catalunya ${ }^{77}$ y "G.", en La Publicitat encontraron en el trabajo de Pruna de "Les Matelots", además de la coreografía y la actuación de los bailarines. Por contra, la música les pareció que no aportaba nada a esta obra:

La partitura de "Les Matelots", condimentada amb ritmes oportunistes $\mathrm{i}$ algunas harmonies ja catalogades, no aporta res de nou que hom pugui prendre en consideració. La coreografía,amb força matissos també oportunistes, acrobàtica i molt en caràcter, entreté agradablement. L'execució dels dansaires, excelent.

El que millor ha reeixit en la composición d'aquesta obra és el pintor Pruna, que ha pintat un decorat molt notable, entonat $\mathrm{i}$ ple de suggestions. ${ }^{78}$

75 A.M., "Debut de la compañía de bailes rusos", Diario de Barcelona, 8 de mayo de 1927, p. 35.

76 B. de P. "Liceo. Bailes Rusos", El correo Catalán, 8 de mayo de 1927, p.6.

77 J.LL., "Els balls russos de Serge de Diaghilew", La Veu de Catalunya, 11 de mayo de 1927, p. 6.

78 "G", "Balls russos", La Publicitat, 10 de mayo de 1927, p. 6. 
$Y$ es que escenografía a parte, el tema de la música en su parte interpretativa ya venía siendo señalada por el propio Llongueras desde su primera crónica sobre este ballet. En general, consideraba poco trabajada la orquesta bajo la dirección del maestro Goosens. ${ }^{79}$

El día siguiente al estreno de la compañía en Barcelona, domingo 8 de mayo, se programó una sesión de tarde con las obras "Les Sylphides", "Les matelots" y por primera vez esta temporada "Carnaval" 80 El martes 10 de nuevo en sesión nocturna en la cartelería del Liceo se anunciaron los ballets "La boutique fantastique", como novedad "Les Biches" $y$ "Le mariage d'aurore" ${ }^{81} \mathrm{En}$ este caso el estreno de "Les Biches" acaparó la atención de las crónicas de la sesión.

"X." en La Publicitat criticó la partitura de Poulenc porque decepcionaba en su búsqueda de clichés sin éxito para dotar a la obra de un carácter cómico que no conseguía. Donde la pretendida modernidad musical creaba en el ballet una representación más propia de revista que de un teatro como el Liceo. Solo salvaba la obra por la coreografía y las actuaciones de los bailarines rusos. También pareció entender que el público no estaba ante algo excepcional por su pobre respuesta al final de la representación:
"Poulenc és un músic talentós, però sembla que esmerça deplorablement les seves facultats. En la partitura de "Les Biches" hi ha coses ben reeixides; un cert sabor popular força picant $\mathrm{i}$ una vena melòdica fàcil i simpàtica fan agradosos alguns dels seus episodis, però en conjunt ens deixà decebuts. L'efecte còmic musical és perseguit per làutor amb l'aplicació de clixés gastats que han perdut eficàcia. Manca també d'originalitat aquesta música massa despreocupada. Tantes invectives com han pronunciat contra Ravel aquests cridaners sediciosos de darrera hora, i tots acuden a consultar, sense disimular-ho gaire, els rics vocabularis de l'autor de "Dafnis"! A més a més, quan voldrán deixar en pau el "Pulcinella" de Stravinsky. La part vocal ha estat suprimida. La coreografía és molt notable i el artistes russos fan una excellent tasca, sobretot els homes. L'acció del ballet és d'una oportuna vaguetat. Sense això, tot el que tindria el seu marc apropiat en una revista, apareixeria massa fora de lloc en un teatre de les condicions del Liceu". 82

\footnotetext{
79 J. Llongueras, "Els balls russos al Liceu", La Veu de Catalunya, 8 de mayo de 1927, p. 6.

80 El Diluvio, 8 de mayo de 1927, p. 6.

81 "Balls russos", La Publicitat, 10 de mayo de 1925, p. 6.

82 "Liceu. Balls russos", La Publicitat, 12 de mayo de 1927, p. 4.
} 
Por su parte Joan Llongueras en La Veu de Catalunya tampoco valoró de forma muy positiva la música de Poulenc. Se declaraba desorientado ante el insulso espectáculo ofrecido por la compañía de Diaghilev a la que consideraba que se encontraba en pleno declive artístico. ${ }^{83}$ En la misma línea crítica sobre la música de Poulenc se situó la reseña de La Vanguardia. Pero a diferencia de lo escrito en otras crónicas, para este diario la coreografía fue, simplemente, vaciada de contenido. ${ }^{84}$

El jueves 12 de mayo en sesión nocturna se incluyeron dos nuevos estrenos: "Zephir et Flore" y "Romeo y Julieta". Cerró la noche "L'mariage d'Aurore". ${ }^{85}$ Ninguna de las dos novedades presentadas causó gran sensación ni en la crítica ni el público asistente al Liceo como mostró la crónica de la sesión de $B$. de P. en El Correo Catalán:

"En "Romeo y Julieta" ...bailable, la música debida a Constant Lambert tiene bien definido el sentido irónico que imprime carácter a la obra. Pero sólo en contados momentos se sostiene a buena altura. La ejecución escénica, así en lo que respecta a la pantomima, como en el desarrollo de la parte coreográfica, no desmerece de las buenas exhibiciones del teatro ruso bailable. Los artistas fueron, muy aplaudidos. Boris Kochno puso música a los tres cuadres de "Céfiro y Flora", sólo de una manera discreta. La representación de esta obrita tiene algún detalle discutible, por más que la seriedad y alto sentido artístico que es norma de la Compañía Diaghilew., deja siempre a salvo los pormenores del espectáculo. El público no convencióse enteramente, pero, de todos modos no quiso desaprobar estas dos nuevas exhibiciones, y llamó repetidas veces al proscenio a sus intérpretes" ${ }^{86}$

De esta sesión A.M., en el Diario de Barcelona destacó la interpre-

83 J. LL, "Balls Russos de Diaghilew. Les Biches", La Veu de Catalunya, 12 de mayo de 1927, p. 6.

84 "Gran Teatro del Liceo. Los bailes rusos", La Vanguardia, 11 de mayo de 1927, p. 21.

85 La Vanguardia, 12 de mayo de 1927, p. 14.

86 B. de P., "Bailes rusos", El Correo Catalán, 13 de mayo de 1927, p. 5. El crítico en su crónica también señaló el interés de Juan Mestres en la presentación de estrenos en la temporada de bailes rusos, que a su juicio demostraba la voluntad de la empresa en variar los carteles sesiones rusas. Pero por otro lado, advertía que este hecho fuera a costa de "el prurito de la disonancia" y "el recurso demasiado socorrido de la estridencia" para buscar siempre la novedad. 
tación de los bailarines en "Romeo y Julieta" porque con su actuación el espectador se podía olvidar de lo "insípido" de la música y podría distraerse con el decorado de Joan Mirò:

"El argumento de este "ballet" cuya acción tiene lugar durante una lección de danza y ensayo, de los mismos Bailes Rusos, es en síntesis los amoríos de "Danilova" y "Lifar" que los induce a huir en avión después de haber efectuado el ensayo de "Romeo y Julieta" en la sala del teatro. Hay una escena en la que se ve pasar a los danzarines hacia el escenario donde ha de tener efecto el ensayo. Esta escena es sin música $y$, sin embargo, el interés subsiste por la gran expresión que ponen los intérpretes en sus evoluciones y casi diríamos que no sola subsiste el interés, sino que el sentido musical agradece esta pausa" ${ }^{87}$

X., desde las páginas de La Publicitat también mostraba su decepción antes estos dos nuevos estrenos porque no reflejaban lo que se esperaba de la compañía de Diaghilev. Solo destacó, una vez más, la actuación de los bailarines. Se preguntaba entonces el crítico si eran las novedades, por no ser lo esperado por el público, o quizás una producción demasiado moderna para los gustos de los espectadores del Liceo lo que provocó que no disfrutara con la representación:

""Romeo i Julieta" i "Zèfir i Flo$\mathrm{ra}^{\prime \prime}$...aquests dos ballets no han deixat tampoc satisfet l'interès amb què eren esperades les novetat que porten enguany es notables artistes russos. La música del primer és del compositor anglès Constant Lamber, al qual hom no sabria negar, coneguda esta partitura, qualitats molt estimables, però que semblen poc madurades i no ben orientades encara......La música de Duklesky és molt poc interessant, monòtona i poc colorida, plena de vulgaritats i d'un aire tudesc poc escaient al caràcter de l'obra. La tasca dels dansarins en aquet ballet $i$ en l'altre estrenat, fou excelent per tots conceptes. Cal esmentar, sobretot, la senyora Danilova i els senyor Massien i Ligar, admirables tot hora. Les dues obras foren rebudes amb prevenció. Potser ha vingut un xic de nou tot això i el públic no sap divertir-s'hi". ${ }^{88}$

87 A.M., "Bailes Rusos", Diario de Barcelona, 14 de mayo de 1927, p. 6.

88 X., "Liceu. Balls russos", La Publicitat, 15 de mayo de 1927, p. 6. Joan Llongueras en La Veu de Catalunya, reflejó la misma idea de falta de entusiasmo del público ante estos dos estrenos 
Muchas de las demandas de la crítica y público reflejadas en la prensa al inicio de las sesiones de bailes rusos de este año, fueron motivadas por la presentación de unas novedades artísticas que ya no recordaban a lo visto en temporadas anteriores de la compañía de Diaghilev. Es decir, no se ofrecían obras de su "repertorio clásico". ${ }^{89}$ Así que no fue hasta el reestreno en Barcelona de "Petruchka" el sábado 14 de mayo cuando esta demanda pareció ser satisfecha a la vista de parte de la crítica que seguía las evoluciones de los ballets russes. Completaron el cartel otras obras clásicas como "Carnaval" y "Romeo y Julieta":

"Con "Petruchka", la compañía de Sergio Diaghilew se redimía anoche de las culpas de los pasados días, y llevaba de nuevo por sus naturales cauces al "ba"let" ruso... No se puede decir que el tiempo transcurrido entre el estreno de "Petruchka" y la representación de ahora haya atenuado el placer de su audición. La música de Strawinsky, que con soberana fuerza comenta el drama escénico, no ofrece sorpresas de estilo ni de procedimientos... Carnaval, vieja historia de amores entre máscaras y lindas mujercitas; admirables escenas, compuestas por Fokine sobre la romántica música de Schumann, con hondo sentimiento del arte, figuraba también en el programa de anoche. La interpretación no mejoró otras anteriores: pero fué más que discreta, y sostuvo vivos el interés y el alto valor del artístico espectáculo". 90

En la misma línea crítica Joan Llongueras calificó los ballets "Petrouchka" y "Carnaval" como de los que más éxito han tenido siempre convirtiéndose en "indispensables" dentro del amplio conjunto de producciones de Diaghilev. De "Carnaval", Llongueras creía que su popularidad venía marcada por su carácter romántico y por lo conocida que era su música. Sin embargo, "Petrouchka", calificada como uno de los grandes aciertos de Stravinsky por el crítico de La Veu de Catalunya, la consideraba un modelo dentro del mundo de la danza y una de las obras que más fama le habían dado a los Ballets Russes:

"Petrouchka, és i derà sempre un dels grans encerts de Strawinsky. La música aquesta té un caràcter formidable $\mathrm{i}$ té riquesa de color i té exuberància de vida. Cada personatge

de la noche, en cambio la última obra de la programación, "L'mariage d'Aurore", si que recibió "la comprensió del públic en general", J. Llongueras, "Balls Russos al Liceu", La Veu de Catalunya, 13 de mayo de 1927, p. 6. 
és en ella admirablemente carcateritzat i cada escena magistrament descrita. L'assumpte és una vertibale troballa. L'interès de l'obra no decau un sol momento i el tràgic desenllaç amb la mort de "Petrouchka", víctima de la vida que li ha donat el nigromàntic $a m b$ sa màgia $i$ les cruels increpacions que, per damunt la barraca, dirigeix el pobre putxinelli al seu fatal animador, produexien sempre una fona emoció i una forta esgarrifança. ${ }^{\prime \prime 1}$

\section{El 15 de mayo de 1927 a las 17:15} horas en la segunda sesión de tarde de la temporada se programaron "La boutique fantastique", "Le mariage d'Aurore" y las danzas de "El príncipe Igor". ${ }^{92}$ El 17 de mayo de 1927 se celebró en el Liceo la gala del XXV aniversario de la coronación del Rey Alfonso XIII' ${ }^{93}$ dentro de los actos que se venían celebrando durante este día y los sucesivos tanto en Madrid como en Barcelona por la efeméride real. ${ }^{94}$ El programa de la noche se configuró con "Petrouchka", "El sombrero de tres picos" y las danzas de "El príncipe lgor" donde Massine cuajó una gran actuación y el público aplaudió mucho todas las actuaciones:

"La tasca dels artistes russos en aquests ballets ha estat d'un extraordinari relleu. Dins el conjunt, admirable sempre, ha destacat especialment el senyor Massine, que ha fet un "Petrutxka" incomparable, i, en la suculenta obra de Falla,

89 La crítica se refería a obras, sobre todo de Stravinksy u otras que tuvieron gran éxito en su primera etapa en Barcelona.

90 Z.,"Gran Teatro del Liceo. Petruchka", La Vanguardia, 15 de mayo de 1927, p. 23.

91 J. LL., "Gran Teatre del Liceu. Balls Russos de Diaghilew", La Veu de Catalunya, 15 de mayo de 1927, p. 8.

92 La Publicitat, 17 de mayo de 1925, p. 11. Programa de manos de la sesión del 15 de mayo de 1927. BNF, département Bibliothèque-musée de l'Opéra, AID-931 (6, 258-293) [https:// gallica.bnf.fr/ark:/12148/btv1b8419216p].

93 La Publicitat, 17 de mayo de 1927, p. 9.

94 El Diario de Barcelona, por ejemplo, dedica sus primeras 14 páginas a noticias sobre la efemerides real, destacando desde notas de prensa de 1902 cuando fue nombrado Rey hasta todas las celebraciones que se iban a dar sobre todo en Barcelona, pero también en Madrid y en otras provincias de España. Aunque también informa sobre celebraciones en ciudades fuera de España como Buenos Aires o Berlín. Diario de Barcelona, 17 de mayo de 1927, pp. 1-14. Los días 18 y 19 el Diario de Barcelona continuaba con las informaciones sobre los actos ya celebrados reservados a las primeras páginas. Ver crónica completa de la sesión en Z., "Gran Teatro del Liceo. El sombrero de tres picos", La Vanguardia, 18 de mayo de 1927, p. 10. 
un "Moliner" prodigiós. Es tot el ballet las seva actuació és $d^{\prime}$ un interès excepcional: però la seva gran dansa, en particular -episodi dels més reeïxits de l'obra- és tod un poema. El públic ha celebrat molt i aplaudit unànimement aquestes representacions". ${ }^{95}$

El miércoles 18 en horario nocturno los ballets russes representaron por primera vez esta temporada "Cimarosiana" y "Las mujeres del buen humor". Cerraba el programa "El sombrero de tres picos" con gran triunfo entre el público. Llongueras, en su crítica de la sesión introdujo una larga reflexión tras observar la coreografía cuasi-estática de los bailarines en "Las mujeres del buen humor", que contrastaba con la música alegre de Scarlattí. Se preguntaba por la importancia de la música en los distintos componentes técnicos de la danza, y de cómo los bailarines de Diaghilev no llegaron a desarrollar una sensibilidad musical acorde con sus movimientos en la representación artística de este arte. A raíz de este argumento creía necesario crear un "contrapunt plàstic-corporal per damunt de la música", es decir, ir más allá de la música en la función estética de la danza:
"Quan per la dansa, avui día, se demana la cooperación de la música no és prou que la dansa sía una pantomima, una estilització més o menys ben sentida, un joc convencional, una nota de color, un divertiment pels ulls, caldía també que aquesta dansa ultra tot això tingués també una essencial indispensable valor de musicalitat. LLavors els moviments de dansa trobarien matisos i detalls d'expressió i d'emoció viva del tot insospitable ara i la dansa es trobaría infinitament enriquida. Els qui, amb ulls de pintor o amb fantasies de literat s'entusiasmaren davant d'algun dels ballets nous que han estat donats enguany, es deixaren enlluernar per la visió anecdótica i no s'adonaren que gairebé sempre la música era una monótona i molt pobra de plasticitat i que en els moviments aquells, de tan aguda $i$ atrevida estilització, mancava per complet la sensibilitat musical que tota veritable i artística realització plàstica ha de tenir indispensablement". ${ }^{96}$

Al día siguiente, jueves 19 de mayo, continuó la programación con, de nuevo, dos estrenos de temporada "Carnaval" y "Thamar"; com-

95 "Liceu. Balls russos", La Publicitat, 19 de mayo de 1927, p. 6.

96 J. LL., "Gran Teatre del Liceu. Balls russos de Diaghilev", La Veu de Catalunya, 19 de mayo de 1927, p. 6. 
pletaron el cartel "Cimarosiana" y las danzas de "El príncipe lgor".97 Joan Llongueras en su crónica en La Veu de Catalunya calificó "Thamar" como poco moderna al encasillarla como un ballet de antes de la guerra. También señaló la falta de interés del público del Liceo durante esta temporada por el espectáculo de los ballets russes de Diaghilev. ${ }^{98}$ El viernes 20 la función estuvo compuesta por "Les femmes de bonne humeur", "Petrouchka" y "El sombrero de tres picos". Era la primera de la tres sesiones de despedida de Barcelona por parte de la compañía de Diaghilev:

"Con las funciones de hoy, viernes, mañana sábado, y domingo, tarde, se despediran de nuestro público los famosos Balltes Rusos en el Gran Teatro del Liceo. No ha sido posible lograr el que dieran unas funciones más tan celebrados artistas moscovitas por tener que debutar en París el próximo martes. Los programas de estas últimas funciones lo constituyen las obras que mayor éxito han alcanzado en Barcelona, siendo el del sábado y el del domingo, por la tarde verdaderamente atractivos". 99

El sábado 21 de mayo en el mismo horario nocturno se programó "El matrimonio de Aurora", "Thamar" y "La boutique fantastique". ${ }^{100} \mathrm{El}$ domingo 22 a las 17:45 horas se celebró la que sería la última sesión de los bailes rusos en el Gran Teatro del Liceo de esta temporada de primavera de 1927 con las representaciones de "Cimarosiana", "Petrouchka" y "El sombrero de tres picos". ${ }^{101}$

Al igual que pasó con el primer estreno de "Les Sylphides", que abrió como novedad la primera sesión en España un 26 de mayo de 1916 en Madrid, los bailes rusos finalizaron sus giras en Barcelona, coincidiendo, al igual que el año de su estreno en España, con los actos conmemorativos de la proclamación como rey de Alfonso XIII. ${ }^{102}$ Quedaba ya

97 La Vanguardia, 19 de mayo de 1927, p. 18.

98 J. LL., "Gran Teatre del Liceu. Balls russos de Diaghilev", La Veu de Catalunya, 20 de mayo de 1927, p. 6.

99 "Despedida de los bailes rusos", Diario de Barcelona, 20 de mayo de 1927, p.13.

100 Fue retransmitida por Radio Barcelona. La Vanguardia, el 21 de mayo de 1927, p. 17.

101 "Gran Teatro del Liceo. Despedida de los Bailes Rusos", La Vanguardia, 24 de mayo de 1927 , p. 25.

102 En el Heraldo de Madrid, del 17 de mayo de 1916, $4^{a}$ edición, en su portada se puede ver la noticia donde describen todos los actos que se celebran ese día con motivo del cumpleaños y al aniversario de su coronación como Rey de España. Por otro lado en el diario $A B C$, del 16 
lejos la expectación artística que causaron sus actuaciones en Madrid y Barcelona durante los años 1916 y 1917 motivadas por la falta de escenarios para actuar en Europa a causa de la Primera Guerra Mundial.

\section{Conclusiones}

Los años de estas últimas giras de la compañía de Diaghilev en Barcelona vinieron marcados, en líneas generales, por la caída de la asistencia de público a las sesiones y la falta de novedades interesantes para los espectadores. Así lo reflejaron la mayoría de críticos artísticos que cubrieron informativamente las funciones de la troupe rusa en el Gran Teatro del Liceo. Quizás la temporada de 1924 fue la que mayor éxito de público tuvo motivada por un lado por la vuelta de los ballets russes y por el estreno de "El sombrero de tres picos". La propia crítica de espectáculos mostró un amplio interés por la obra de Falla y Picasso y reservó grandes espacios para las crónicas en los diferentes diarios. El ballet de inspiración española fue junto "Pulcine"la", los grandes reclamos para el público barcelonés que se congregaba en la sala a disfrutar de un espectáculo que muchas veces no entendió (se hallaba "desorientado al igual que parte de la crítica que no terminó de asimilar las nuevas producciones de Diaghilev. Solo en "El Tricorni", donde el público vio reflejada a una España costumbrista escenificada bajo el prisma cubista de Picasso, se abrió la escenografía al conocimiento del espectador, que en este caso, si intuía que estaba pasando sobre el escenario. No obstante la crítica de espectáculos mantuvo durante cada temporada el anhelo de presenciar novedades en la cartelera de cada año de los ballets russes durante estas tres temporadas en Barcelona. Aunque no siempre se llegaron a cumplir las expectativas de los críticos. En algunos casos como los estrenos de "Les Maletots" o "Les biches", simplemente no se las consideró representaciones propias de la compañía de Diaghilev por no ofrecer el producto cultural que esperaban del empresario ruso. En otros por ejemplo, como fue la presentación del ballet "Le mariage d'Aurora", no fue lo esperado: "¡No es això!". Incluso el propio Joan Llongueras lle-

de mayo de 1916, en su página 15, se puede leer la noticia de la llegada de la compañía de bailes rusos de Diaghilev al puerto de Cádiz. Debutarían en el Teatro Real de Madrid el 26 de mayo de 1916. Se pueden consultar las crónicas del estreno en El Imparcial, 27 de mayo de 1916, p. 2; El Globo, 27 de mayo de 1916, p. 1; Heraldo de Madrid, 27 de mayo de 1916, p. 2.; La Correspondencia de España, 27 de mayo de 1916, p. 3; ABC, 27 de mayo de 1916, p. 17; y El País, 27 de mayo de 1916, p. 3. 
gó a plantear que la compañía había caído en decadencia artística.

Tras las temporadas de 1924 y 1925 la prensa teatral ya demandaba en el año 1927 la vuelta al repertorio denominado por la crítica como el "clásico de los ballets russes". Se refería a obras con música de Stravinsky y algunos ballets de su primera época de antes de la Gran Guerra como "Carnaval". $\mathrm{Si}$ a este hecho se le sumaban las dificultades técnicas en la interpretación musical y la falta de ensayos de los directores con la orquesta de profesores del Liceo. Muchas veces, la parte de las representaciones que correspondía a la música tampoco estaba a la altura respecto del nivel que se le suponía tanto al espectóculo como al escenario donde se representaba. Ni Eugene Goosens ni Edouard Flament pudieron corresponder con la responsabilidad de la dirección musical.

Por otro lado, cabe reseñar el desigual seguimiento que mostraron los diferentes periódicos que cubrieron las funciones de los bailes rusos. Desde resúmenes poco detallados del espectáculo, donde se abusaba de adjetivos sin destacar en análisis centrados en los elementos de la danza y la música, hasta otras crónicas de sesiones más analíticas como las realizadas por Joan Llongueras en La Veu de Catalunya,
" $\mathrm{X}$ " en La Publicitat, y en menor medida "Walter" en La Vanguardia. Parte de esta crítica fue muy minuciosa en la valoración musical de las representaciones de los bailes rusos. En cierto modo, debido a que algunos críticos teatrales ya tenían referencias de antiguas representaciones de las primeras giras de la compañía rusa en Barcelona (años 1917 y 1918). A este hecho se le sumaba que ya se habían escuchado las orquestaciones de algunos ballets de la mano de Pau Casals o el propio lgor Stravinsky en el mismo Liceo ${ }^{103}$ en fechas anteriores a la reaparición de los bailes rusos en la temporada de primavera de 1924. Tras seis años de ausencias de actuaciones en la capital catalana. Sin embargo, a diferencia de lo referido a la vertiente musical del espectáculo, la parte interpretativa fue la que más elogios recibió en la mayoría de los casos por parte de la prensa. Una crítica de espectáculos que reivindico su modernidad muchas veces ante la programación de los bailes rusos, ya desfasadas según su propia visión de las representaciones, pero que tampoco supo entender ni valorar muchas de las propuestas de reciente creación de la empresa de Diaghilev. En cambio los interpretes sí que ocuparon numerosas líneas escritas para destacar ya fuera su belleza, su 
capacidad técnica o su ejecución interpretativa. Woizinovsky, Sokolova, Nijinska, Zverew u otros recogían los elogios de la crítica al día siguiente de sus actuaciones y no eran, sino ellos y el cuerpo de baile quienes despertaban el interés de la prensa y del público como así se puede comprobar en las crónicas periodísticas de las sesiones.

Por último, la compañía en el año 1925 también vivió los nuevos avatares de los tiempos donde por un lado fue por primera vez las actuaciones de la compañía retransmitidas a través de la onda de Radio Barcelona en directo desde el Liceo y por otro, protagonizó la función homenaje al FC Barcelona por sus éxitos deportivos en un curioso programa mixto. Sobre la inclusión de las retransmisiones de la radio en conciertos y espectáculos como en el caso de los ballets russes, hubieron quejas de algunos empresarios teatrales en lo que se denominó "la crisis del teatro". Si bien los empresarios pudieron culpar a una falta de público en sus programaciones a estas retransmisiones, críticos como Alard defendieron las emisiones en directo a través de las estaciones de radio como medio para subir la popularidad de algunos espectáculos o autores. $^{104}$
Tras la muerte de Diaghilev en agosto de 1929, dos años después de su última visita a Barcelona, la compañía de ballets russes de Diaghilev desapareció como proyecto empresarial. No fue hasta unos años más tarde cuando de la mano de W. Basil y Massine se retomaría el proyecto de una gran compañía de ballet siguiendo la estela dejada por el empresario de San Petersburgo. Así un 4 de mayo de 1935 volverían los ballets russes a Barcelona con el nombre de Bailes rusos de Montecarlo. Abrieron el día de su reaparición con el ballet "Les Silfides", como venía siendo costumbre en la compañía de Diaghilev en su primer día de función, completaron el programa las obras "Le Bal" (se estrenaba en Barcelona), "Los presagios" y "El Danubio azul". ${ }^{105}$

\section{BiblioteCAS, ARCHIVOS Y CENTROS DE DOCUMENTACIÓN}

Arxiu de Revistes Catalanes Antigues (ARCA).

Arxiu Históric de la Societat del Gran Teatre del Liceu.

Arxiu Municipal Contemporaní de Barcelona.

Centre de Documentació i Museu de les Arts Escèniques de la Diputació de Barcelona.

104 Incluso afirmaba que en las retransmisiones desde el Liceo se podían apreciar "gran claridad en los amalgamas de los timbres orquestales", suponía por la instalación de nuevos micrófonos. Alard, "Las emisiones de Radio Barcelona", El Diluvio, 13 de mayo de 1925, p. 16.

105 El Diluvio, 4 de mayo de 1935, p. 2. 
www.gallica.bnf.fr.

www.bne.es

\section{FUENTES IMPRESAS}

$A B C$

El Correo Catalán

La Correspondencia de España

La Época

Diario de Barcelona

El Diluvio

El Globo

Heraldo de Madrid

El Imparcial

El País

La Publicitat

La Vanguardia

La Veu de Catalunya

La Voz de Guipuzcoa

\section{Biblografía}

BUCKLE, Richard (1978), Diaghilev: costumes and designs of $\mathrm{Ba}$ llets, The Metropolitan Musemum of Art, Nueva York.

BUCKLE, Richard (1984), Diaghilev, Hamish Hamilton, Londres.

CASTILLO, Pedro (2017), Crónicas españolas de los bailes rusos de Dia- ghilev (1916-1927), Tesis Doctoral, Universitat Jaume I de Castelló.

GARAFOLA, Lynn (1998), Diaghilev's ballets russes, Da Capo Press, Boston. GARITAONAINDIA, Carmelo (1988). La radio en España (1924-1939), Madrid, Siglo XXI.

GRIGORIEV, Serge L. (1960), The Diaghilev Ballet, 1909-1929, Penguin Books, Harmondsworth, 1960. GRIS, Juan, "Correspondencia y Escritos", ed. $M^{a}$ Dolores Jiménez Blanco, El Acantilado, Barcelona, 2008.

HESS, Carol (2002), Manuel de Falla and the modernism in Spain (1898-1936), Chicago University Press, Chicago.

SALAÜN, Serge y SERRANO, Carlos (eds.) (2007), Los felices años veinte: España, crisis y modernidad, Marcial Pons, Madrid.

SOKOLOVA, Lydia (1960), Dancing for Diaghilev, ed. Richard Buckle, John Murray Publ., Londres.

THARRATS, Joan-Josep (1982), Picasso $i$ el pintors catalans en el baIlet, Edicions del Cotal, Barcelona. 



\section{Pedro Castillo}

Licenciado en Antropología Social y Cultural por la UNED y Doctor por la Universitat Jaume I. Actualmente trabaja como funcionario de carrera en la Administración Local. Sus temas de estudio se centran la historia cultural y las artes escénicas, con especial interés en los fenómenos culturales y la producción artística de la segunda y tercera década del siglo XX en España.

al190527@uji.es

\section{Elena Fernández}

Doctora con Mención Europea con la tesis "Las mujeres en los Inicios de la Revolución Liberal española (1808-1823)". Desde 2008, ha combinado la docencia en el Departamento de Historia Moderna y contemporánea de la Universitat Autònoma de Barcelona con su labor como como técnica superior de investigación en la misma universidad. Actualmente, está vinculada al Centro de Historia de la Ciencia para el proyecto "Modern Science, Technology and Medicine, 19th-20th centuries!" [2017SGR 1 138]. Es autora de Mujeres en la Guerra de la Independencia (2010), y ha participado en obras colectivas como Mujeres y culturas políticas en España. 1808-1845 (2013) o Expulsiones y exclusiones de la España oficial en época contemporánea (2019).

Elena.Fernandez@uab.cat

\section{Isabel García}

Investigadora predoctoral FPI de la UNED con la tesis "El proceso de radicalización de mujeres yihadista en España". Licenciada en Periodismo por la Universidad Pontificia de Salamanca (UPSA). Máster en Ciencia Política en la Universidad de Salamanca (USAL) y en Paz, Seguridad y Defensa por el Instituto Universitario Gutiérrez Mellado y UNED. Ha publicado algunos estudios en revistas como Historia del Presente.

mis.garcia@igm.uned.es 


\section{Maila García Amorós}

Profesora Ayudante Doctora en el Departamento de Filología Griega y Filología Eslava de la Universidad de Granada y miembro del grupo de investigación Estudios de la Grecia medieval y moderna. Defendió su tesis doctoral "Autobiografía e historia en la obra de loanna Tsatsos" en 2008 de la que han resultado diferentes trabajos en revistas especializadas y obras colectivas como Mundo griego: tradición y modernidad (2007), La mitología griega en la tradición literaria: de la Antigüedad a la Grecia Contemporánea (2017), entre otros. Ha trabajado también sobre la figura del poeta Yorgos Seferis. Especial interés le ha prestado al tema de la repercusión en la literatura griega moderna de la Catástrofe de Asia Menor de 1922.

maila@ugr.es

\section{Javier Hernández}

Doctor en Historia por la Universitat de València (2004). Profesor de Educación Secundaria en la especialidad de Geografía e Historia. Su tesis doctoral se publicó bajo el título Poderosos pleitos: conflictividad, litigantes y estrategias judiciales en el Señorío de Montesa, siglos XVI-XVII (2014).

hernandez1974javier@gmail.com

\section{Carlos Martínez Carrasco}

Doctor en Historia Medieval por la Universidad de Granada. Investigador en el Centro de Estudios Bizantinos, Neogriegos y Chipriotas de Granada. Su campo de trabajo son las relaciones islamo-bizantinas y el impacto de las corrientes heterodoxas del cristianismo durante los siglos VII-VIII en el Oriente Mediterráneo.

cmtnez@ugr.es

\section{Mateo Morandi}

Investigador en historia contemporánea en la Universidad Tor Vergata de Roma, bajo la dirección científica de la profesora Marina Formica. Ha estudiado la circulación de los mitos políticos y su adaptación en el área mediterránea durante el siglo XIX, y publicado los resultados de su investigación en revistas históricas y volúmenes colectivos entre 2017 y 2018 . Durante su formación doctoral, realizada conjuntamente entre Tor Vergata y la Universitat Autónoma de Barcelona analizó los circuitos de comunicación y los símbolos a través de los cuales se contaban los trastornos revolucionarios de 1848 mediante pequeñas tipologías documentales. Ha analizado los cánones de la iconografía, la caricatura, la novela histórica y la escultura, con resultados en curso de publicación.

teopompo@gmail.com 


\section{Francisco Ramiro Moya}

Doctor en Historia por la Universidad de Zaragoza. Diploma de especialista en Historia Militar por la UNED. Su investigación ha estado centrada fundamentalmente en la historia de las mujeres y las resistencias femeninas en la Edad Moderna. Es autor de diferents artículos en revistas especializadas y de capítulos de libro sobre esta temática. Es autor de Mujeres y trabajo en la Zaragoza del siglo XVIII (2012).

franciscoramiromoya@gmail.com

\section{Manuel Santirso Rodríguez}

Profesor en la Universitat Autònoma de Barcelona. Es autor de Revolució liberal i guerra civil a Catalunya (1999), El liberalismo, una herencia disputada (2014) y La construcción del catalanismo. Historia de un afán político (2014), este último con Jaume Claret. Muy recientemente, ha editado junto con Alberto Guerrero el volumen colectivo Mujeres en la guerra y en los ejércitos (2019), y con Jordi Pomés, Patrias alternativas (2019). Dirige la revista Rubrica Contemporanea.

manuel.santirso@uab.cat

\section{Adrian Shubert}

Catedrático de Historia en la York University (Canadá). En su larga trayectoria merecen destacarse sus obras Hacia la revolución: orígenes sociales del movimiento obrero en Asturias, 1860-1934 (1984), Historia Social de Espana, 1800-1990 (2000), A las cinco de la tarde. Una historia social del toreo (2002) y, últimamente, Espartero. El Pacificador, (2018). Es miembro de la Royal Society of Canada y ha sido beneficiario de las prestigiosas Killam Research Fellowship (Canadá) y Guggenheim Fellowship (EEUU).

adriansh@yorku.ca 



\section{Revisors/es Reviewers}

L'equip editoral de la revista Millars. Espai i Història vol agraïr als/a les investigadors/res que han reatlizat les avaluacions prèvies dels articles que han estat presentats per a ser publicats en aquest volum.

Rosa María Alabrús Iglesias (Universitat Abat Oliva)

Miguel Alonso Ibarra (Universitat Autònoma de Barcelona)

Borja Antela Bernardez (Universitat Autònoma de Barcelona)

Antonio Cazorla (Trent University)

Francisco Escribano Bernal (Universidad de Zaragoza)

Laia Falcón Díaz-Aguado (Universidad Complutense de Madrid)

María Jesús Fuente (Universidad Carlos III)

Aitana Guía Conca (California State University - Fullerton)

María Martí Escayol (Universitat Autònoma de Barcelona)

Javier Martínez Babón (Museo Egipcio de Barcelona)

Xosé Manoel Núñez Seixas (Universidade de Santiago de Compostela)

Marc Orriols Llonch (Universitat Autònoma de Barcelona)

Antoni Ripollés Mansilla (Universitat Jaume I)

Claudia Rosas (Ponticifia Universidad Católica del Perú)

Laura Ruiz de Elvira Carrascal (Institut de Recherche pour le

Développement, CNRS)

Adrian Shubert (York University)

Rocío Velasco de Castro (Universidad de Extremadura)

Daniel Yépez Piedra (Universitat Autònoma de Barcelona) 


\section{Dossier}

\section{Elena Fernández y Manuel Santirso (Coords.) \\ Entre Hestia y Atenea. Mujeres en el hogar y en el combate}

\section{Elena Fernández y Manuel Santirso}

Género y guerra, una encrucijada y una oportunidad

\section{Carlos Martínez Carrasco}

'A' isha bint Abī Bakr: mujer, guerra y poder en la Arabia paleo-islámica antes de la primera fitna

\section{Francisco Ramiro Moya}

La participación femenina en los sitios de Zaragoza. La percepción del mando militar y el interés del poder político

\section{Javier Hernández Ruano}

"Seremos hombres y fieras". Modelos, roles y actitud de las mujeres durante el bloqueo y asedio austracista de Peníscola (1706-1707)

\section{Adrian SHubert}

Agustina de Aragón in Cairo. Women warriors and National Heroes in Global History

\section{Matteo Morandini}

"Si pudiera convertirme en hombre". Género, política y sociedad:

la redefinición de lo femenino en el largo 48 italiano

\section{Malla Garcia Amorós}

La participación de la mujer en las distintas formas de resistencia durante la ocupación de Grecia por las fuerzas del Eje (1940-1944)

\section{Isabel Garcia}

Las dinámicas de género en las brigadas femeninas de la guerra siria

\section{Estudis}

\section{Pedro Castillo Palomares}

Las últimas giras de los bailes rusos de Diaghilev en España:

Barcelona (1924-1927) 